Historic, Archive Document

Do not assume content reflects current scientific knowledge, policies, or practices. 



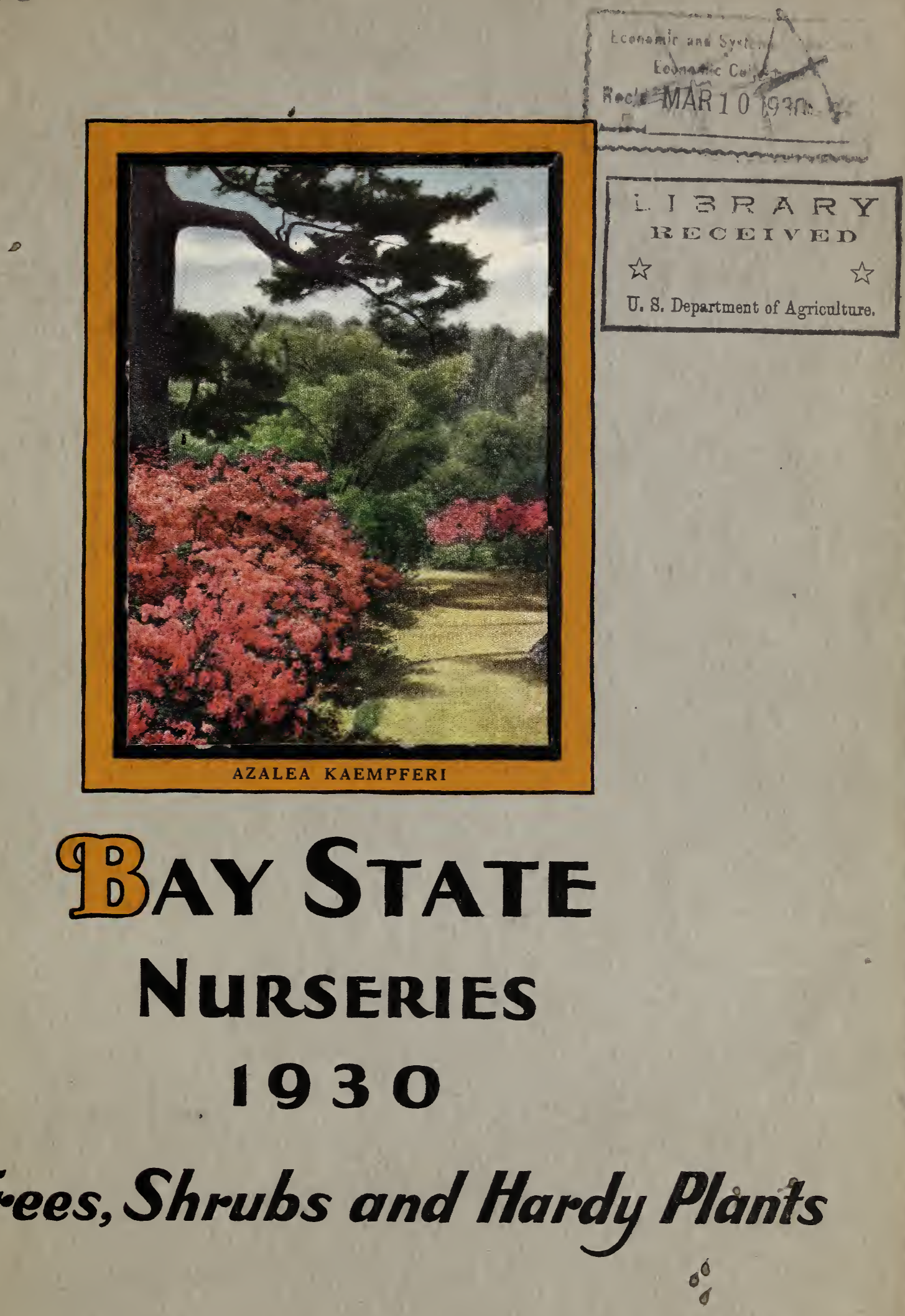

\section{Trees, Shrubs and Hardy Plants 0}





\section{BAY STATE NURSERIES $1894-1930$}

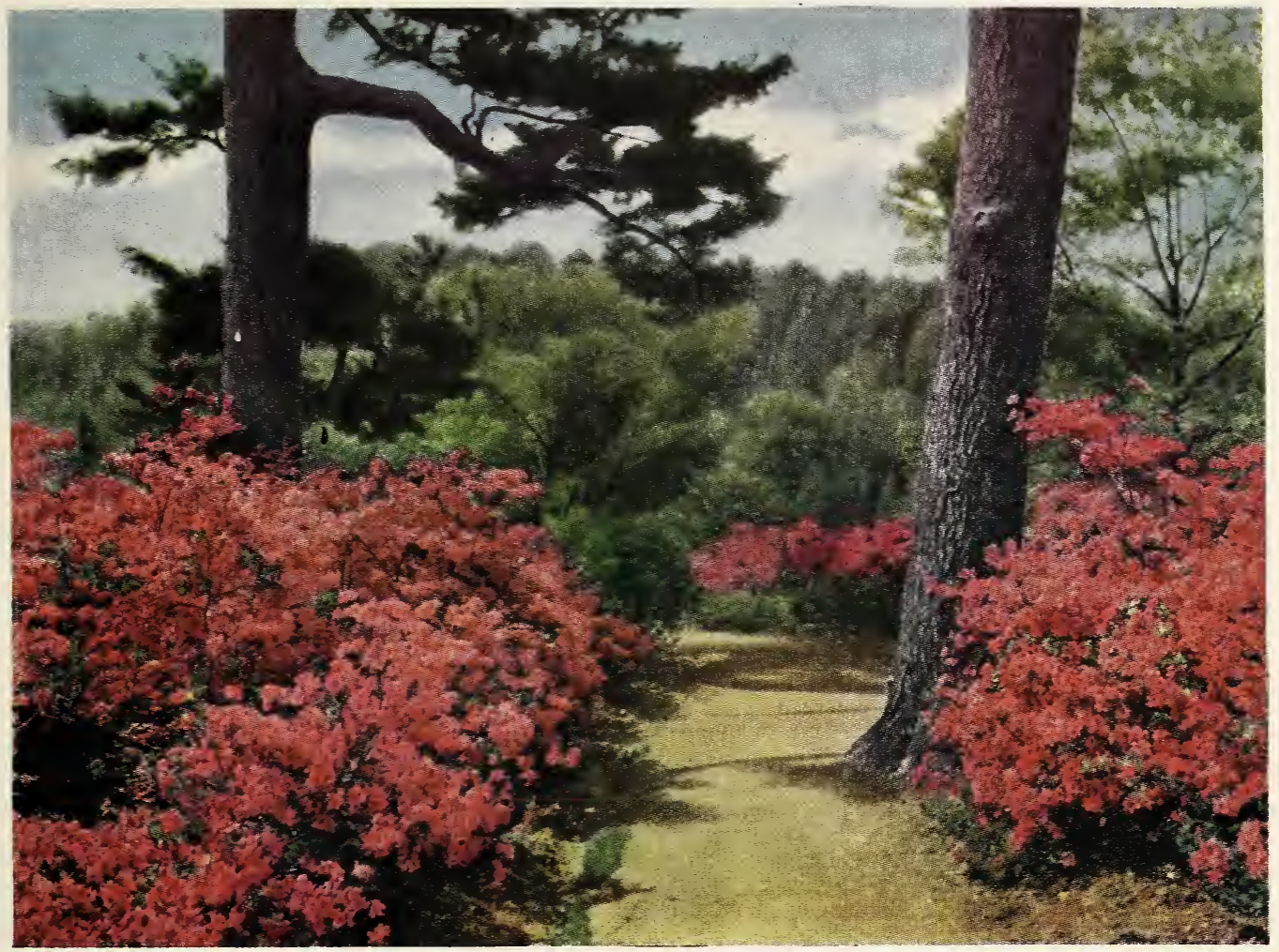

$\mathrm{O}$

NCE more, in presenting our catalogue, we greet our customers and friends. We are sure you will find this handbook more helpful than ever before. As in the past, we have endeavored to eliminate inferior varieties, adding newer and rarer sorts that are really desirable.

The descriptions are brief, but we believe they are accurate, and that the plants will fully justify them when properly cared for.

We thank the people who have so generously patronized us in the past and so kindly expressed approval, not only of the quality of our stock but also of our methods of packing, and assure them that our standards of quality and thorough packing are even higher now than ever. From a very small beginning in 1894 , with less than 1 acre, our nursery has grown until it now covers over 700 acres of land, of which there are 300 acres under cultivation at all times. It is not our ambition just to have the very largest nursery in the country, but we do want to increase the number of varieties that we grow and to maintain one of the largest collections of ornamental nursery stock in the United States, as we have in the past.

We take this opportunity to extend a cordial invitation to the readers of this catalogue to visit our nursery. We feel sure that a pleasant surprise will be experienced. When in this neighborhood, do not fail to call upon us. 


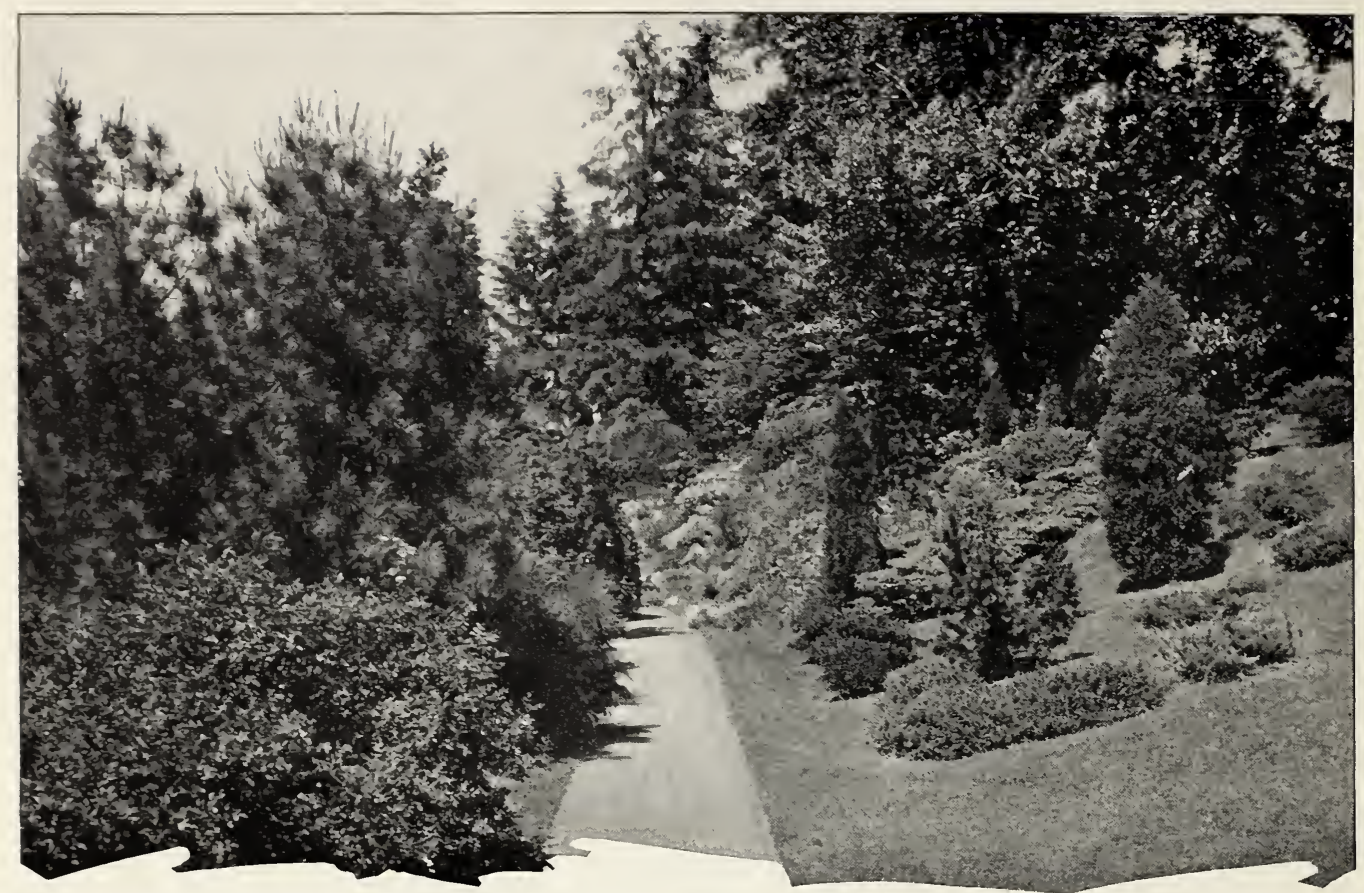

A hillside transformed by Evergreens into a garden of delightful variety in form and ever-changing color values, beautiful all the year round

\section{EVERGREEN TREES}

$\mathrm{T}$

HERE are no more beautiful things in nature than well-grown, well-cared-for Evergreen Trees. They are gracious and cool-looking in summer and cozy and comfortable in winter, adding just the proper touch of green amid the ice and snow to heighten the beauty of our New England landscapes. We have always grown a great variety of Evergreens and have many acres devoted to them where they are carefully tended from seedlings and grafts to bushy, well-developed trees. In order to make them surer to grow and easy to handle when out of the ground, we transplant them frequently, to produce a ball of thread-like roots which will hold the soil firmly and allow them to be shipped and replanted with the least possible check and every assurance that they will live and prosper.

There is no end to their uses, just as there is no end to their infinite variety. Probably the owner of a small place will find best use for the dwarfer, slow-growing types which he can nestle around the foundation of his house, or group artistically at the corners of his steps, or in front of the porch. The larger place must have them for fine foliage groups, for windbreaks, for enclosing private portions of the grounds, for special formal treatment of various parts of the garden.

\section{ABBREVIATIONS}

Denoting Varieties Suitable for Seashore Planting: $(\dagger)$.

Denoting Rapidity of Growth: r, rapid; m, medium; s, slow; $v$, vigorous.

Denoting Size: L, Iarge; M, medium; S, small; D, dwarf; VD, very dwarf.

Five or more plants of one kind will be furnished at 10 rate

\section{ABIES - Fir}

A Iarge family of shapely trees with beautiful foliage, usually growing to great height, and in the first twenty-five or thirty years are most ornamental, attaining great picturesqueness with age. Firs should be planted as individual specimens or as a screen. They should not be used in foundation plantings.

Abies concolor. Wbite Fir. ( $\mathrm{Lm}$ ) A very hardy tree from the Rocky Mountains, with foliage of varying shades of dark green and blue. It grows rapidly and withstands heat and drought. As a single specimen, it is one of the most graceful and perfect trees, and the showiest of all the Firs. 5 to $6 \mathrm{ft}$., \$15 each; 4 to $5 \mathrm{ft}$., \$12 each; 3 to $4 \mathrm{ft}$., \$10 each.

A. fraseri. Fraser Fir. (Lr) Similar in appearance to the Balsam Fir, which does not grow satisfactori!y in Massachusetts, but a superior tree in this climate and farther south because of its darker foliage. 3 to $4 \mathrm{ft}$., $\$ 6.50$ each; 2 to $3 \mathrm{ft}$., $\$ 5$ each.

\section{ABIES, continued}

A. veitchi. Veitcb Fir. (Lr) The most rapid-growing of the Firs, making a tall, symmetrical tree with dark foliage, silvered on the under side. Very hardy and especially desirable for planting as a specimen. 4 to $5 \mathrm{ft}$., $\$ 11$ each; 3 to $4 \mathrm{ft}$., $\$ 8$ each; $21 / 2$ to $3 \mathrm{ft}$., $\$ 6.50$ each; 2 to $21 / 2 \mathrm{ft}$., $\$ 5$ each.

\section{CHAMAECYPARIS Japan Cypress}

This family includes some of the most graceful and beautiful trees in Nature. Their soft feathery foliage is particularly attractive and they make splendid backgrounds for other planting. In smaller sizes they do weIl in window-boxes, are excellent for small formal effects, and grow weIl in tubs.

Chamæcyparis obtusa gracilis. Slender Hinoki Cypress. (VDs) A very handsome, slow-growing, bushy evergreen, with dense, dark, extremely vivid foliage. Unusually attractive. $2 \mathrm{ft}$., $\$ 5$ each. 


\section{CHAMECYPARIS, continued}

C. pisifera. Sawara Retinospora. (Lr) An upright, graceful tree, slightly pendulous at the end of the branches. In northern latitudes it should be planted in sheltered locations. 3 to $31 / 2 \mathrm{ft}$., $\$ 5$ each; $21 / 2$ to $3 \mathrm{ft}$., $\$ 4$ each; 2 to $21 / 2 \mathrm{ft}$., $\$ 3.50$ each.

C. pisifera aurea. Golden Sauara Retinospora. (Lr) Like the preceding, except for its beautiful golden foliage. 3 to $31 / 2 \mathrm{ft}$., $\$ 5$ each; $2 \frac{1}{2}$ to $3 \mathrm{ft}$., $\$ 4$ each; 2 to $2 \frac{1}{2} \mathrm{ft}$., $\$ 3.50$ each.

C. pisifera filifera. Thread Retinospora. (Ms) A most ornamental tree, with deep green, string-like, drooping foliage which it retains at all seasons of the year. Best of all, it thrives in more or less shady places, and is extremely effective in foundation plantings and for massing with other evergreens. 3 to $31 / 2 \mathrm{ft}$., $\$ 6.50$ each, $\mathrm{S} 60$ for $10 ; 21 / 2$ to $3 \mathrm{ft}$., $\$ 5.50$ each, $\$ 50$ for $10 ; 2$ to $21 / 2 \mathrm{ft}$., $\$ 5$ each, $\$ 40$ for 10 .

C. pisifera filifera aurea. Golden Tbread Retinospora. (Ms) We like this tree the best of the Golden Cypresses. It is very much like the Thread Retinospora in style of plant but is even slower in growth, and keeps its rounded, compact form for many years. The foliage is bright golden yellow which makes a beautiful contrast with other evergreens. 3 to $31 / 2 \mathrm{ft}$., $\$ 12$ each; $21 / 2$ to $3 \mathrm{ft}$., $\$ 9$ each; 2 to $21 / 2 \mathrm{ft}$., $\$ 7$ each; 18 to 24 in., \$5 each.

C. pisifera plumosa. Plume Retinospora. (Ms) Soft, feathery, light green foliage, and very graceful. To keep it from becoming open and ragged it should be sheared in the middle of June. AII Japan Cypresses are splendid for plantings around the foundation of the house, and this variety is particularly fine for that purpose. 3 to $31 / 2 \mathrm{ft}$., S6 each, S57 for $10 ; 21 / 2$ to $3 \mathrm{ft}$., $\$ 4.50$ each, $\$ 40$ for $10 ; 2$ to $21 / 2 \mathrm{ft}$., $\$ 3.50$ each, $\$ 30$ for $10 ; 18$ to 24 in., $\$ 2.75$ each, $\$ 25$ for 10 .

C. pisifera plumosa aurea. Goldenplume Retinospora. (Ms) A golden form of the preceding. It is one of the most popular evergreens, particularly liked for its rich yellow foliage, which shows up weIl among the more somber evergreens. 3 to $31 / \mathrm{ft}$., $\$ 5.50$ each, $\$ 50$ for $10 ; 21 / 2$ to $3 \mathrm{ft}$., $\$ 4.50$ each, $\$ 40$ for $10 ; 2$ to $21 / 2 \mathrm{ft}$., $\$ 3.50$ each, $\$ 30$ for $10 ; 18$ to 24 in., $\$ 2.75$ each, $\$ 25$ for 10 .

C. pisifera plumosa lutescens. Dwarf Retinospora. (VDs). A dwarf, globe-shaped plant, with feathery foliage of lighter color than the preceding. It is valuable for its low growth and the extra color tone it brings to the evergreens. $21 / 2 \mathrm{ft}$., $\$ 7$ each; $2 \mathrm{ft}$., $\$ 5.50$ each; 18 in., $\$ 4.50$ each.

C. pisifera plumosa sulphurea. Sulphurplume Retinospora. (Ms) Similar to C. pisifera plumosa aurea, but the color is more brilliant, and is retained throughout the year. Prices and sizes same as Cbamæcyparis pisifera plumosa aurea.

C. pisifera squarrosa. Moss Retinospora. (Ms) An ornamental Japanese tree, with fleecy, bluish gray foliage, quite distinct from that of other evergreens. It should be planted in somewhat sheltered positions and its unusual beauty will repay the attention given it. $2 \mathrm{ft}$., $\$ 5$ each; 18 in., $\$ 4$ each.

\section{JUNIPERUS · Juniper}

Stately trees which are very effective in garden and landscape. There are low forms which make splendid covers for banks and rough ground. Junipers are invaluable for formal effects, many of them having the fine columnar form required for architectural emphasis. They are very hardy.

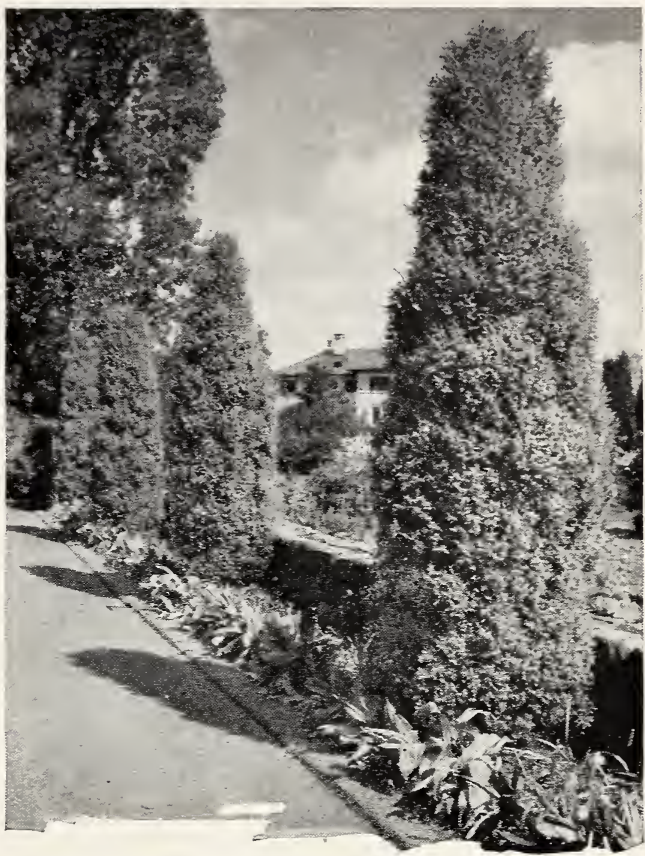

Juniperus chinensis columnaris. Valuable for its stateliness and beauty of texture.

JUNIPERUS, continued

Juniperus chinensis. Cbinese Juniper. A handsome, gray-green tree, reaching 60 feet with age, but which can be kept lower and shrubbier. Very hardy easy to grow, and makes a fine neutral background for flowering shrubs and other low evergreens. $21 / 2$ to $3 \mathrm{ft}$., $\$ 6.50$ each; 2 to $21 / 2 \mathrm{ft}$., $\$ 5.50$ each.

J. chinensis columnaris. Columnar Cbinese Juniper. Compact, narrow tree, with gravish foliage. Very formal and useful for accent points, specimens, and special architectural effects. $41 / 2$ to $5 \mathrm{ft}$., $\$ 11$ each, $\$ 95$ for 10.

$\dagger J$. chinensis pfitzeriana. Pfuzer Juniper. (Ss) A dwarf, fan-shaped evergreen with horizontal, spreading branches, as broad as tall, of rough grayish green. It is very hardy, will thrive under very unfavorable conditions, and is very weIl adapted to planting about foundations, entrances and beside steps. We call special attention to the large sizes in which we can furnish this popular variety. These will produce a finished, established, Iong-planted effect the first season. 4 to 5 -ft. spread, $\$ 16$ each; $31 / 2$ to 4 -ft. spread, $\$ 12$ each, $\$ 115$ for $10 ; 3$ to $31 / 2$ - ft. spread, $\$ 8.50$ each, $\$ 80$ for $10 ; 21 / 2$ to $3-\mathrm{ft}$. spread, \$6.50 each, $\$ 60$ for $10 ; 2$ to $21 / 2$-ft. spread, $\$ 5$ each, $\$ 45$ for 10 ; 18 to 24 -in. spread, $\$ 3.50$ each, $\$ 33$ for 10 .

J. chinensis sargenti. Sargent's Juniper. Trailing shrub, with erect branchlets, forming dense mats which make a handsome ground-cover and are particularly useful on banks and in rock gardens where it can be allowed to develop naturally. Its foliage is silvery gray-green, a restful color and one which harmonizes with any surroundings. 15 to 18 in., \$4 each; 12 to 15 in., \$3 each.

This Catalogue does not adequately illustrate the quantities of evergreens we grow and have to offer in various sizes. If you are looking for a large number of evergreens for hedge or screen purposes, let us quote on your requirements. If you are looking for sizes not mentioned in the Catalogue, we can frequently furnish both smaller and larger sizes. If you will write us we will be very glad to tell you what sizes we can furnish, and at the same time give you the prices. 
JUNIPERUS, continued

$\dagger$ J. communis depressa. Common Spreading Juniper. Very hardy variety with light bluish foliage. It will live in light, sandy soil and withstand severe exposure. Splendid for rock gardens and locations where broad, low foliage effects are desired. $21 / 2$ to $3 \mathrm{ft}$., $\$ 5.50$ each; 2 to $21 / 2 \mathrm{ft}$., $\$ 4$ each; 18 to 24 -in. spread, \$3.25 each.

$\dagger \mathbf{J}$. communis depressa plumosa. Plumed Prostrate Juniper. A variety of the preceding with feathery foliage which turns rich bronzy green in winter and is exceedingly handsome for similar uses. 15 to 18 in., \$3 each, \$24 for 10.

J. communis hibernica. Irisb Juniper. (Mm) A slender, columnar tree with bluish green foliage. Much used for border planting. A most attractive species when planted among other evergreens and in spots sheltered from severe winds. 4 to $41 / 2 \mathrm{ft}$., $\$ 6.50$ each, $\$ 60$ for $10 ; 3$ to $31 / 2 \mathrm{ft}$., $\$ 5$ each, $\$ 45$ for $10 ; 21 / 2$ to $3 \mathrm{ft}$., $\$ 4$ each, $\$ 36$ for $10 ; 2$ to $21 / 2 \mathrm{ft}$., \$3 each, \$27 for 10.

J. communis suecica. Swedisb Juniper. (Mm) Very similar to the Irish Juniper, but hardier, and its branches droop slightly, giving it a most graceful and informal appearance. 3 to $31 / 2 \mathrm{ft}$., $\$ 5.50$ each, $\$ 50$ for $10 ; 21 / 2$ to $3 \mathrm{ft}$., $\$ 4.50$ each, $\$ 40$ for $10 ; 2$ to $21 / 2 \mathrm{ft}$., $\$ 3.50$ each, $\$ 33$ for 100 .

J. excelsa stricta. Spiny Greek Juniper. Very ornamental, narrow, dense tree of erect growth, with bristly gray-green foliage. 18 to 24 in., $\$ 4$ each, $\$ 36$ for $10 ; 15$ to 18 in., \$3 each, \$27 for 10 .

J. horizontalis. Creeping Juniper. A splendid plant for banks, rocky slopes, and rock gardens, making a broad, dense mat on the ground. It is often found growing wild, both in swamps and on dry sanddunes, showing its wide range of adaptability. 2 to $2 \frac{1}{2} \mathrm{ft}$., $\$ 5.50$ each, $\$ 52$ for $10 ; 18$ to $24 \mathrm{in}$., \$4.50 each, \$42 for 10.
J. japonica. Japanese Juniper. Low and shrubby, with bending branches and needle-like leaves. A very decorative and hardy evergreen for many uses. 18 to 24 in., $\$ 5.50$ each, $\$ 50$ for 10 .

†J. sabina. Savin. (VDs) A half-erect plant, eventually becoming 6 to 8 feet high. Good for rockwork. Its graceful stature and unchanging deep green foliage adds a solid and enduring tone to a mixed planting. 2 to $21 / 2 \mathrm{ft}$., $\$ 5$ each; 18 to 24 in. $\$ 4$ each, $\$ 36$ for $10 ; 15$ to 18 in., $\$ 3$ each, $\$ 27$ for 10 .

J. sabina tamariscifolia. Tamarix Savin. (VDs) A low, dense, trailing plant of very neat habit, clothed with bright, gray-green foliage. Excellent on banks or rockwork. 18 to 24 in., $\$ 5.50$ each; 15 to 18 in., $\$ 4$ each.

J. virginalis globosa. Globe Cbinese Juniper A dwarf, very hardy Chinese Juniper with rich green foliage which keeps bright and fresh all season, making clean, fresh ornamental specimens for formal or informal use in the garden or in tubs. 18 to 24 in., $\$ 7.50$ each; 15 to 18 in., \$5 each.

$\dagger J$. virginiana. Redcedar. ( $\mathrm{Mm}$ ) A native, common in New England, which should be more generally planted. It is of pyramidal shape, with bright, rich green foliage. Very hardy, thriving in partial shade, in light sandy soils, and will withstand severe exposures. It is very useful for formal gardens giving a grace and dignity that cannot be supplied by any other hardy tree. 5 to $6 \mathrm{ft}$., $\$ 9$ each; 4 to $5 \mathrm{ft}$., $\$ 6.50$ each, $\$ 60$ for $10 ; 3$ to $4 \mathrm{ft}$., $\$ 4.50$ each, $\$ 42$ for 10 .

†J. virginiana glauca. Silver Redcedar. (Mm) One of the handsomest forms of the hardy Redcedar, which is a little denser in habit than the common Red Cedar and has silvery gray foliage which keeps its color all year. $2 \frac{1}{2} \mathrm{ft}$., $\$ 6$ each; $2 \mathrm{ft}$., $\$ 4.50$ each.

Experienced packers will ship your material so that it will arrive in perfect condition

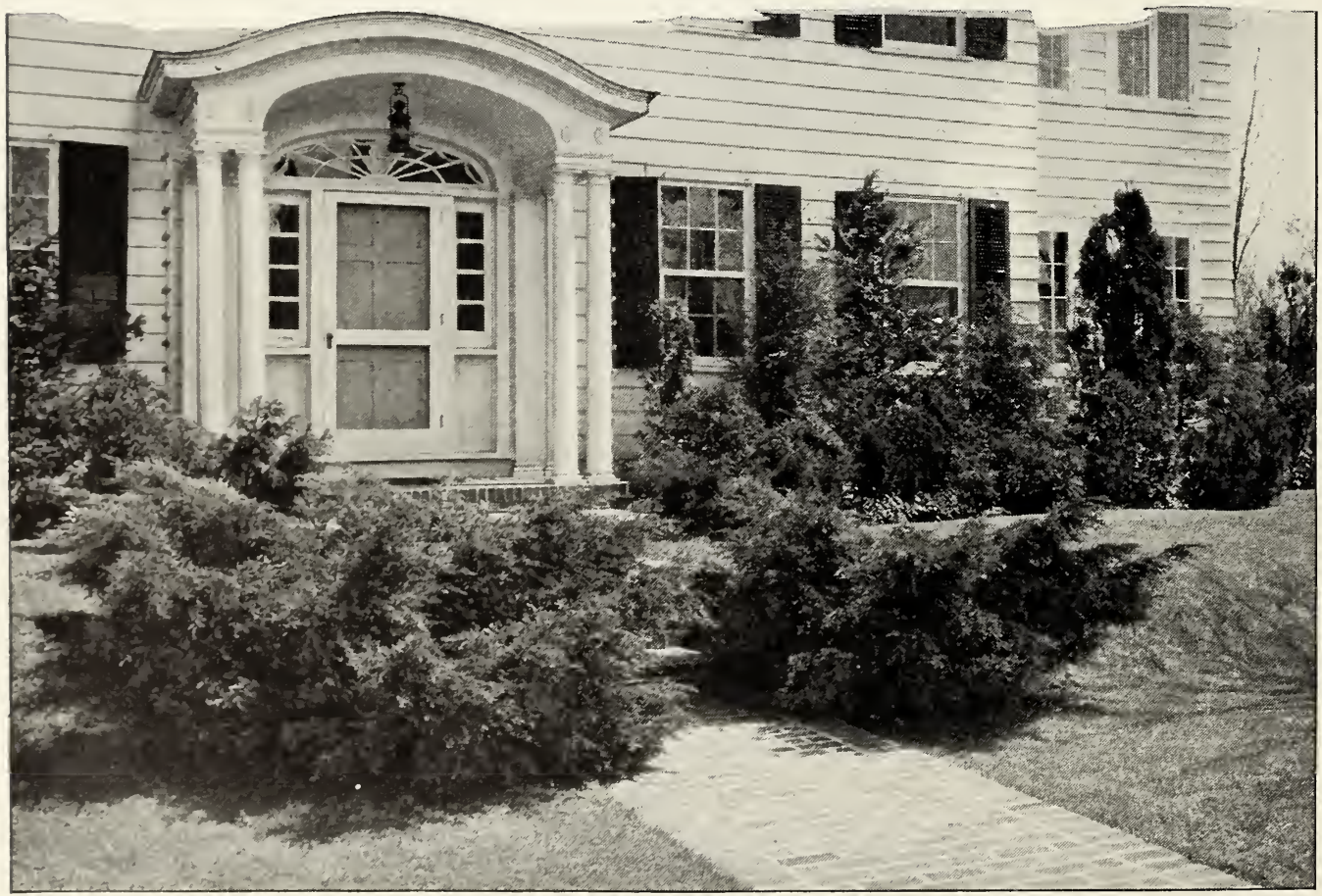

Juniperus chinensis pfitzeriana softening the edges of the steps with feathery, friendly green 


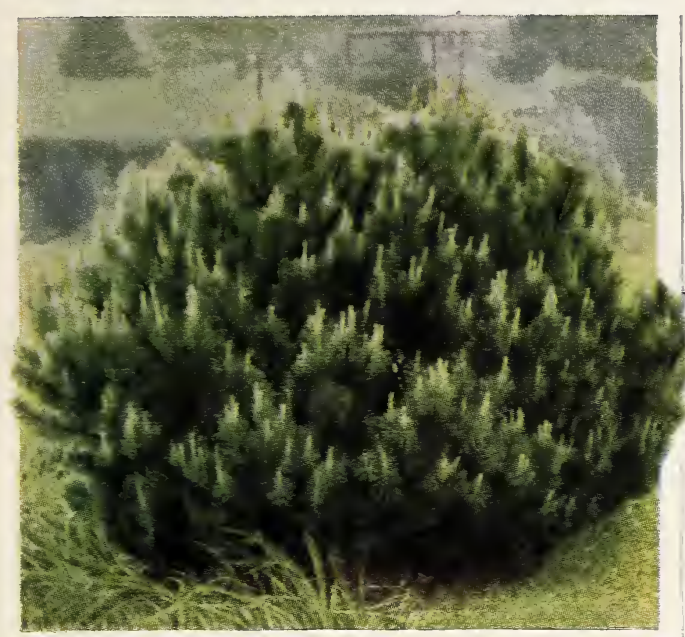

Mugho Pine. As it looks in spring lit by its own candles.

\section{PICEA · Spruce}

The beautiful spires of the Spruces are most effective in landscape and garden planting. They are similar to the firs but vary in several minor points of botany, and can be used for similar purposes, making splendid avenue effects, magnificent groups, and growing rapidly into efficient windbreaks.

tPicea canadensis. Wbite Spruce. ( $\mathrm{Lm})$ One of the best North American conifers. It is a compact and upright tree of great longevity, with light, silvery green foliage. It makes a handsome specimen and is splendid for windbreaks, screen planting, and large hedges. Any kind of soil suits it, and it will endure much clipping and pruning. 3 to $4 \mathrm{ft}$., $\$ 5.50$ each, $\$ 50$ for $10 ; 21 / 2$ to $3 \mathrm{ft}$., $\$ 3.75$ each, $\$ 35$ for 10 ; 2 to $2 \frac{1}{2} \mathrm{ft}$., $\$ 3$ each.

†P. excelsa. Norway Spruce. (Lr) A hardy, rapidgrowing evergreen that adapts itself to almost any soil. Dense, dark green foliage. Very satisfactory for windbreaks and hedges. Plant small sizes $21 \% 2$ feet apart for a dense hedge. 6 to $7 \mathrm{ft}$., \$9 each, $\$ 85$ for 10 ; 5 to $6 \mathrm{ft}$., $\$ 7$ each, $\$ 65$ for $10 ; 4$ to $5 \mathrm{ft}$. $\$ 5.50$ each, $\$ 50$ for 10 ; 3 to $4 \mathrm{ft}$., $\$ 4$ each, $\$ 36$ for $10 ; 2$ to $3 \mathrm{ft}$., $\$ 2.50$ each, $\$ 22.50$ for 10 .

P. excelsa pendula. Weeping Norway Spruce. (Ss) Similar to the preceding but with drooping branches. Produces novel and striking effects. 5 to $6 \mathrm{ft}$., \$9 each; 4 to $5 \mathrm{ft}$., $\$ 8$ each.

P. glauca conica. Dwarf Alberta Spruce. An excellent dwarf evergreen with dense, very fine foliage; of perfect, conical form and exceedingly slow growth, making it excellent for permanent low plantings. 15 to $18 \mathrm{in}$., $\$ 5$ each, $\$ 45$ for $10 ; 12$ to 15 in., $\$ 4$ each, $\$ 35$ for 10 .

$\dagger$ † . pungens. Colorado Spruce. ( $\mathrm{Lm})$ A slow-growing, hardy conifer of symmetrical habit which is admirably adapted to seashore planting. A very beautiful evergreen. $3 \mathrm{ft}$., $\$ 8$ each; $2 \mathrm{ft}$., $\$ 6$ each, $\$ 55$ for $10 ; 18 \mathrm{in.,} \$ 4$ each, $\$ 37.50$ for 10 .

$\dagger$ †. pungens glauca. Blue Colorado Spruce. A tree of similar habit with distinct, gray-blue foliage. These are beautiful trees, with dense foliage. $2 \frac{1}{2}$ to $3 \mathrm{ft}$., $\$ 10$ each; 2 to $21 / 2 \mathrm{ft}$., $\$ 8$ each, $\$ 75$ for $10 ; 18$ to 24 in., $\$ 6.50$ each, $\$ 60$ for 10.

$\uparrow$ P. pungens Kosteri. Koster Blue Spruce. (Lm) In a general way much like the preceding but uniformly deep silvery blue. Compact, very symmetrical, and most desirable of all. $41 / 2 \mathrm{ft}$., $\$ 42 \mathrm{each}$; $4 \mathrm{ft}$., $\$ 35$ each; $31 / 2 \mathrm{ft}$., $\$ 30$ each.

\section{PSEUDOTSUGA · Douglas Fir}

This is a very small family of trees and seems to combine the characters of both the spruces and the hemlocks. We list only one kind, a very highly desirable and popular tree.

Pseudotsuga douglasi. Douglas Fir. (Lr) A magnificent tree, growing to great height and of majestic appearance when mature. Beautiful in shape and texture when small. Dark bluish green foliage. It grows rapidly and is healthy. Deserves a place on everv estate. 4 to $5 \mathrm{ft}$., $\$ 9$ each; 3 to $4 \mathrm{ft}$., $\$ 6.50$ each, $\$ 60$ for $10 ; 2$ to $3 \mathrm{ft}$., $\$ 4.50$ each, $\$ 40$ for 10 .

\section{PINUS - Pine}

Perhaps the best-known and most popular of all the evergreens, these noble trees are adaptable to many purposes. They are unusually symmetrical in their earlier years and develop a rugged strength with age that is comparable only to that of the oaks.

$\dagger$ Pinus montana mughus. Mugbo Pine. (Ds) Very valuable where a low, dense, evergreen growth is desired. Foliage deep green. Very hardy. A most useful shrub for lawn decoration, for rockwork, or covering hillsides. It grows broader than it is tall. 18 to 24 -in. spread, $\$ 4$ each; 15 to 18 -in. spread, $\$ 3.50$ each, $\$ 30$ for $10 ; 12$ to 15 -in. spread, $\$ 2.75$ each, $\$ 25$ for 10 .

$\dagger$ P. nigra. Austrian Pine. (Lr) A tree of considerable size, with bold, long, dark green foliage. A vigorous, rugged grower, thriving in ordinary soil, in more or less unfavorable situations and by the seashore. Probably no evergreen will withstand so much exposure as the Austrian Pine. 3 to $4 \mathrm{ft}$., $\$ 6.50$ each, $\$ 60$ for $10 ; 2$ to $3 \mathrm{ft}$., $\$ 4.50$ each, $\$ 42$ for 10 .

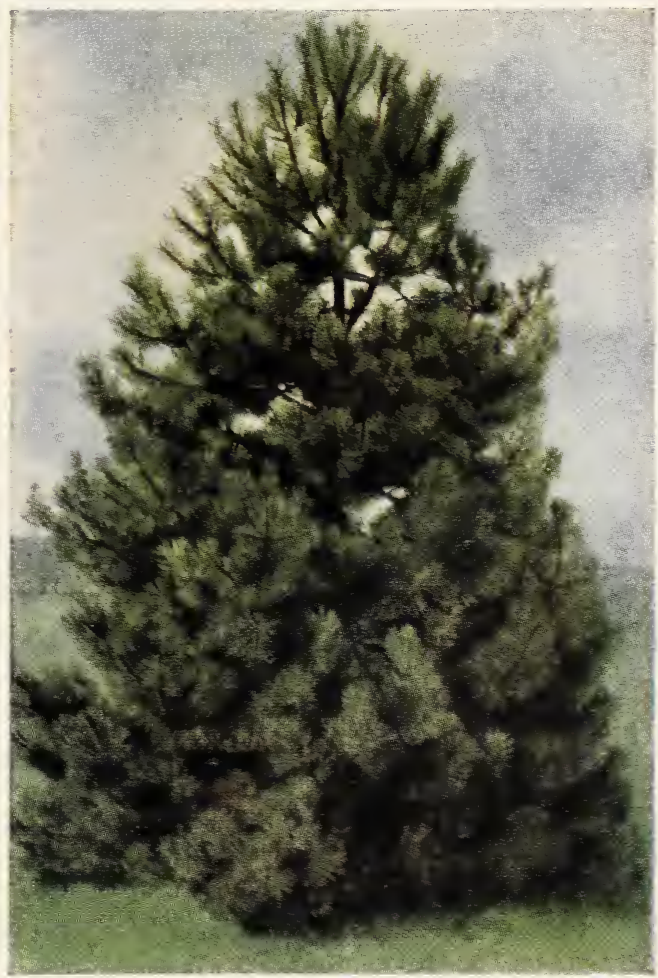

Austrian Pine. Broad, brave trees of magnificent appearance. 


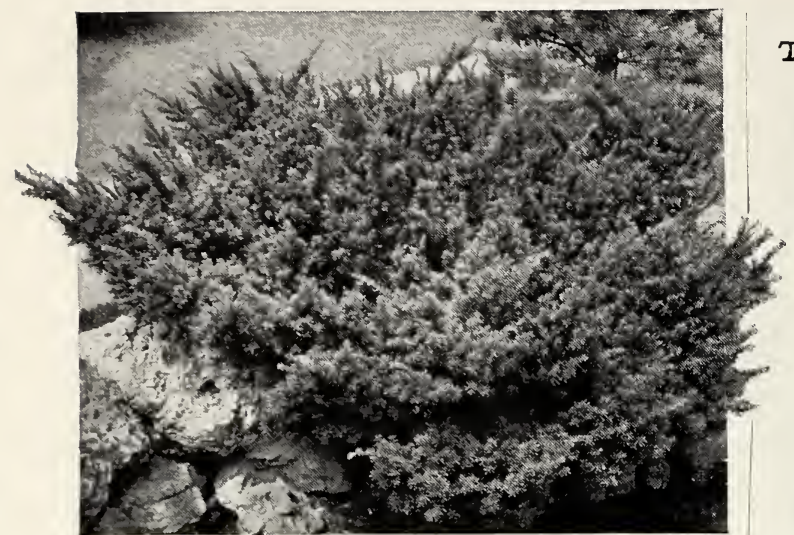

Taxus cuspidata nana. Dwarf Japanese Yew. A very useful plant in the rockery.

PINUS, continued

$\dagger$ P. strobus. White Pine. (Lr) Soft, light silvery green foliage. Highly ornamental when planted singly or in groups. A lofty, noble, native tree. 5 to $6 \mathrm{ft}$., $\$ 10$ each; 4 to $5 \mathrm{ft}$., $\$ 6$ each, $\$ 55$ for 10 ; 3 to $4 \mathrm{ft}$., $\$ 4$ each, $\$ 36$ for $10 ; 2$ to $3 \mathrm{ft}$., $\$ 3$ each; $\$ 27$ for 10 .

$\dagger$ P. sylvestris. Scotcb Pine. (Lr) Desirable for its very rapid growth and adaptability to most soils. It has an uneven, shaggy, and picturesque habit of growth as it matures, with silvery gray-green foliage. The bark is brownish red. 5 to $6 \mathrm{ft}$., $\$ 8$ each, $\$ 75$ for $10 ; 4$ to $5 \mathrm{ft}$., $\$ 5.50$ each, $\$ 50$ for $10 ; 3$ to $4 \mathrm{ft}$., $\$ 4$ each, $\$ 35$ for $10 ; 2$ to $3 \mathrm{ft}$., $\$ 3$ each, $\$ 25$ for 10 .

There is much demand for Scotch Pines in the smaller sizes, in order that a fairly large quantity may be purchased at small cost to be planted in bleak, exposed situations and allowed to grow into windbreaks and screens, on account of their rapidity in growth.

We offer small trees which have already been twice transplanted and are splendid, stocky, little plants. These will be wrapped in bundles of 10 .

$$
\begin{aligned}
& 15 \text { to } 21 \text { in .......\$6 } 00 \quad \$ 5000 \\
& 9 \text { to } 15 \text { in...........4 } 400 \quad 3000
\end{aligned}
$$

We will quote special prices on lots of 1,000 or more

\section{TAXUS • Yew}

The Yews are famous trees, never very Iarge, but they attain great nobility and dignity, living almost forever. Their dark green, almost black foliage is supremely beautiful, and their bright red berries are a unique feature of evergreen trees. They are admirably adapted to hedges or as specimens, and if you like that sort of thing, they may be sheared into very formal shapes.

Taxus baccata aurea. Golden English Yew. The new foliage is rich golden yellow in June, gradually darkening until in the autumn and winter it is a rich vivid green. We highly recommend it as a beautiful, dignified permanent tree. 15 to 18 in., $\$ 3.50$ each, $\$ 32.50$ for $10 ; 12$ to 15 in., $\$ 3$ each, $\$ 27$ for 10 .

T. baccata repandens. Spreading Englisb Yew. (Ds) Of a graceful, spreading form; unchanging foliage of a beautiful shade of dull bluish green. Very hardy and desirable. 18 to $24 \mathrm{in}$. spread, $\$ 7$ each; 15 to 18 -in. spread, \$5 each.

T. baccata washingtoni. Washington Yew. (Ds) Fine golden foliage; handsome and rare; very hardy. $21 / 2 \mathrm{ft}$., $\$ 7$ each.

\section{TAXUS, continued}

T. canadensis. Canada Yew. (Dv) A prostrate evergreen with wide-spreading, slender branches, occasionally reaching a height of 6 feet. Dark green foliage and showy, deep crimson berries. This is a hardy native Yew which thrives in partial shade. 2-ft. spread, $\$ 4.50$ each; 18-in. spread, $\$ 3.50$ each, $\$ 33$ for 10 .

$\dagger$ T. cuspidata. Japanese Yew. (Sm) A compact, spreading variety with attractive, dark green foliage. It is valuable for many locations and is perfectly hardy. It makes attractive, opentopped shrubs or bush-like trees handsome at all seasons, but especially in spring, when its black-green winter foliage is covered with tassels of brilliant yellow-green new growth. In early autumn it sparkles with its myriad bright rose-red fruits. $21 / 2$ to $3-\mathrm{ft}$. spread, $\$ 12$ each; 2 to $21 / 2-\mathrm{ft}$. spread, $\$ 7.50$ each, $\$ 70$ for $10 ; 18$ to 24 -in. spread, $\$ 5$ each, $\$ 45$ for $10 ; 15$ to 18 -in. spread, $\$ 3.75$ each, $\$ 35$ for 10 .

†T. cuspidata capitata. Upright Japanese Yew. (Sm) This is the upright-growing or pyramidal form of the Japanese Yew. It is rather open in growth with rich, dark green foliage, almost black, and exquisitely beautiful when covered with yellowgreen tips of new growth in the spring. It makes a wonderful hedge, and may be used in massing with other evergreens or as a specimen to good effect. It is one of the most desirable evergreens for any purpose and it should be planted liberally. $21 / 2$ to $3 \mathrm{ft}$., $\$ 10$ each; 2 to $21 / 2 \mathrm{ft}$., $\$ 8$ each; 18 to 24 in., $\$ 6$ each, $\$ 57$ for $10 ; 15$ to 18 in., \$4 each, \$38 for 10 .

$\dagger$ T. cuspidata nana. Dwarf Japanese Yew. (Ds) A form of the above with short, dark green foliage which is unchanging throughout the year. A very hardy, dwarf hedge plant of unsurpassed beauty and permanence. It withstands clipping well, and will thrive in unfavorable locations where other evergreens perish. For sheer beauty of color, texture and form, as well as health and longevity, it is one of the most useful and valuable ornamental trees in cultivation. 24 to 30 in., $\$ 18$ each; 21 to 24 in., $\$ 12$ each; 18 to 21 in., $\$ 8$ each, $\$ 75$ for 10 .

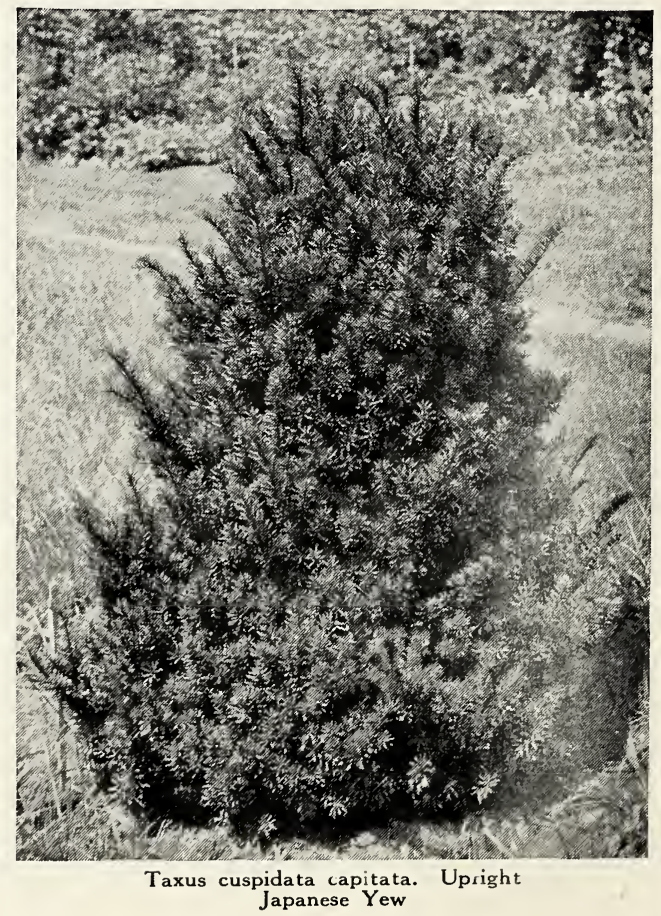




\section{THUYA · Arborvitæ}

These are slender, rather formal trees much used in Iandscape and decorative work. There are many fine dwarf forms, for tub or specimen use, and they may be kept any shape or height desired for many years, as they endure shearing and pruning well.

†Thuya occidentalis. American Arborvitæ.

$(\mathrm{Mr})$

The common, upright flat-leaved evergreen, so commonly used as single specimens and for hedges and windbreaks everywhere. May be kept at any height by shearing. It thrives on moist as well as dry land. 5 to $6 \mathrm{ft}$., $\$ 7.50$ each, $\$ 70$ for $10 ; 4$ to 5 $\mathrm{ft}$., $\$ 5.50$ each, $\$ 50$ for $10, \$ 450$ per $100 ; 3$ to $4 \mathrm{ft}$., $\$ 4$ each, $\$ 35$ for $10, \$ 300$ per 100 .

We grow hundreds of these in each size and can quote even better prices on large quantities.

T. occidentalis compacta. Parsons Arborvitæ. A dwarf, ball-shaped form of the above with light green foliage. $3 \mathrm{ft}$., $\$ 6$ each; $2 \mathrm{ft}$., $\$ 4$ each.

$\dagger \mathrm{T}$. occidentalis douglasi pyramidalis. Douglas Pyramidal Arborvitæ. (Mm) A slender, pyramidal variety of symmetrical outline, with dark fernlike foliage. 4 to $5 \mathrm{ft}$., $\$ 7$ each; 3 to $4 \mathrm{ft}$., $\$ 5$ each, $\$ 48$ for $10 ; 21 / 2$ to $3 \mathrm{ft}$., $\$ 4.50$ each, $\$ 40$ for 10 .

T. occidentalis ellwangeriana. Tom Tbumb Arborvitx. (Sm) Low, broad, compact variety with dense foliage. Dwarf and very graceful. 3 to $4 \mathrm{ft}$., $\$ 5.50$ each, $\$ 52$ for $10 ; 21 / 2$ to $3 \mathrm{ft}$., $\$ 4.50$ each, $\$ 42$ for $10 ; 2$ to $21 / 2 \mathrm{ft}$., $\$ 4$ each, $\$ 35$ for $10 ; 18$ to 24 in., \$3 each, $\$ 27$ for 10 .

T. occidentalis globosa. Globe Arborvitæ. (VDs) A low, slow-growing, dense, globe-shaped variety that is useful for border planting and very satisfactory for low-growing hedges. Very hardy and es. pecially ornamental. 2 to $21 / 2 \mathrm{ft}$., $\$ 4$ each, $\$ 35$ for 10 ; 18 to 24 in., $\$ 3$ each, $\$ 27$ for $10 ; 15$ to 18 in., $\$ 2.50$ each, $\$ 22.50$ for 10 .

T. occidentalis hoveyi. Hovey Arborvitx. (Ds) Another low, globular form, with brighter foliage of golden tinge. It is quite hardy but not so dwarf as T. occidentalis globosa. $3 \mathrm{ft}$., $\$ 4.50$ each, $\$ 40$ for 10 $2 \mathrm{ft}$., $\$ 2.75$ each, $\$ 25$ for $10 ; 18$ in., $\$ 2.50$ each, $\$ 22.50$ for 10 .

$\dagger \mathrm{T}$. occidentalis pyramidalis. American Pyramidal Arborvitæ. (Mr) A very densely branched variety of most distinct columnar growth, with rich, dark glossy green foliage that does not change appreciably in color during the winter months. This is one of the very best Arborvitæs, and is very satisfactory for hedges of medium height for foundation plantings, and for use in tubs. We recommend it very highly. $41 / 2$ to $5 \mathrm{ft}$., $\$ 9$ each; 4 to $41 / 2 \mathrm{ft}$., $\$ 8$; each; $31 / 2$ to $4 \mathrm{ft}$., $\$ 6.50$ each, $\$ 63$ for $10, \$ 600$ per $100 ; 3$ to $31 / 2 \mathrm{ft}$., $\$ 5.50$ each, $\$ 52$ for $10, \$ 480$ per 100 . $21 / 2$ to $3 \mathrm{ft}$., $\$ 4.50$ each, $\$ 40$ for 10 .

We will gladly quote quantity prices to those interested in Iarger quantities than those quoted here.

\section{Evergreens for Foundation Planting}

We recommend the following varieties:

Chamæcyparis (Japan Cypress) in variety.

Junipers (Juniper) in variety.

Pinus montana mughus (Mugho Pine).

Taxus (Yew) in variety.

Thuya (Arborvitæ) in variety.

Do not overlook the Evergreen Shrubs and Rhododendrons which mix splendidly with plantings of Evergreens, particularly on the borders.

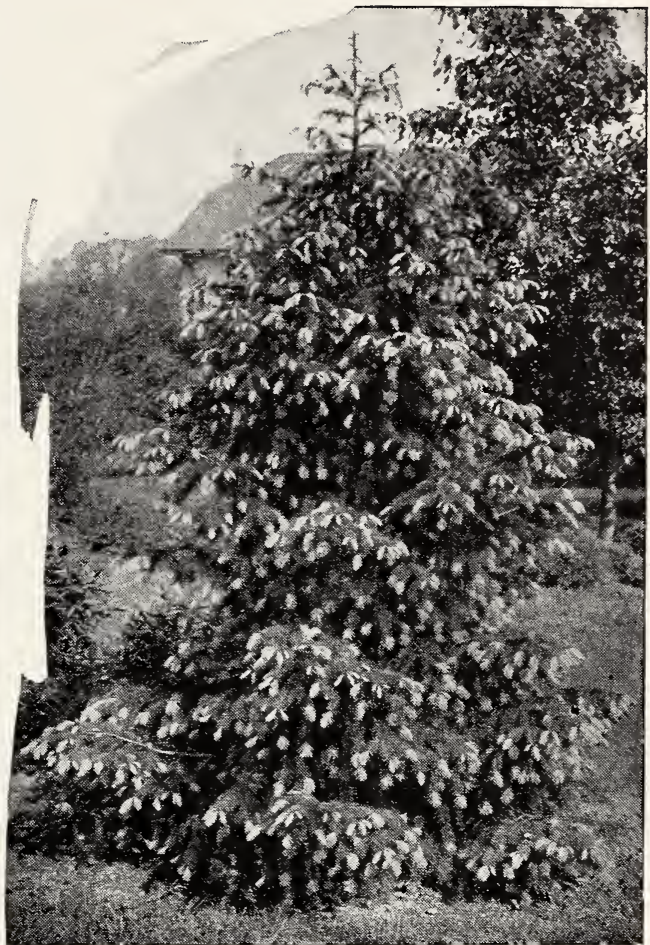

Pseudotsuga douglasi. Blue-green adorned with silvery tips in spring. See page 5

THUYA, continued

T. occidentalis pumila. Green Globe Arborvitæ. (VDs) A very dense, compact form with dark green foliage. 15 to 18 in., $\$ 3.25$ each; 12 to 15 in., $\$ 2.75$ each.

T. occidentalis reidi. Reid Arborvitæ. A low, bushy form, with dark green foliage, good for use in the foreground of evergreen plantings. 2 to $21 / 2 \mathrm{ft}$., $\$ 5.50$ each, $\$ 52$ for $10 ; 18$ to 24 in., $\$ 4.50$ each, $\$ 42$ for 10 .

T. occidentalis rosenthali. Rosentbal's Arborvitæ. An erect, columnar, compact tree, with dark green, Iustrous foliage. Useful for formal plantings or

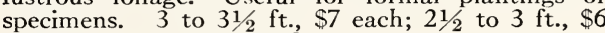
each; 2 to $2 \frac{1}{2} \mathrm{ft}$., $\$ 5$ each.

T. occidentalis vervæneana. Vervæne Arborvitæ. (Sm) A very choice variety of dense habit, with foliage light golden tinge of green. One of the largest and hardiest of all the Arborvitæs, and is particuIarly good for screens and tall hedges. 5 to $6 \mathrm{ft}$., $\$ 10$ each; 4 to $5 \mathrm{ft}$., $\$ 8$ each, $\$ 76$ for $10 ; 3$ to $4 \mathrm{ft}$., $\$ 6$ each, $\$ 57$ for $10 ; 2$ to $3 \mathrm{ft}$., $\$ 4$ each, $\$ 36$ for 10 .

$\dagger$ T. occidentalis wareana. Ware Arborvitæ. (Mv) A very hardy variety with dark steel-gray-green foliage which retains its color all winter. It forms a broad, dense bush, and, like all other Arborvitæs, it is valuable for foundation planting. It also makes a desirable broad hedge of medium height which withstands hard shearing. A most satisfactory variety. 3 to $31 \% \mathrm{ft}$., $\$ 7$ each; $21 / 2$ to $3 \mathrm{ft}$., \$5 each, $\$ 45$ for $10 ; 2$ to $21 / 2 \mathrm{ft}$., $\$ 4$ each, $\$ 36$ for $10 ; 18$ to 24 in., $\$ 3.50$ each, $\$ 33$ for 10 .

T. orientalis. Oriental Arborvitx. The least hardy of all the Arborvitæs and should not be planted north of Boston, but will do well in protected places south of there. The foliage is very soft and of an attractive green during the summer months. $21 / 2$ to $3 \mathrm{ft}$., $\$ 3.25$ each, $\$ 27.50$ for $10 ; 2$ to $21 / 2 \mathrm{ft}$., $\$ 2.75$ each, $\$ 25$ for $10 ; 18$ to 24 in., $\$ 2.25$ each, $\$ 20$ for 10 . 


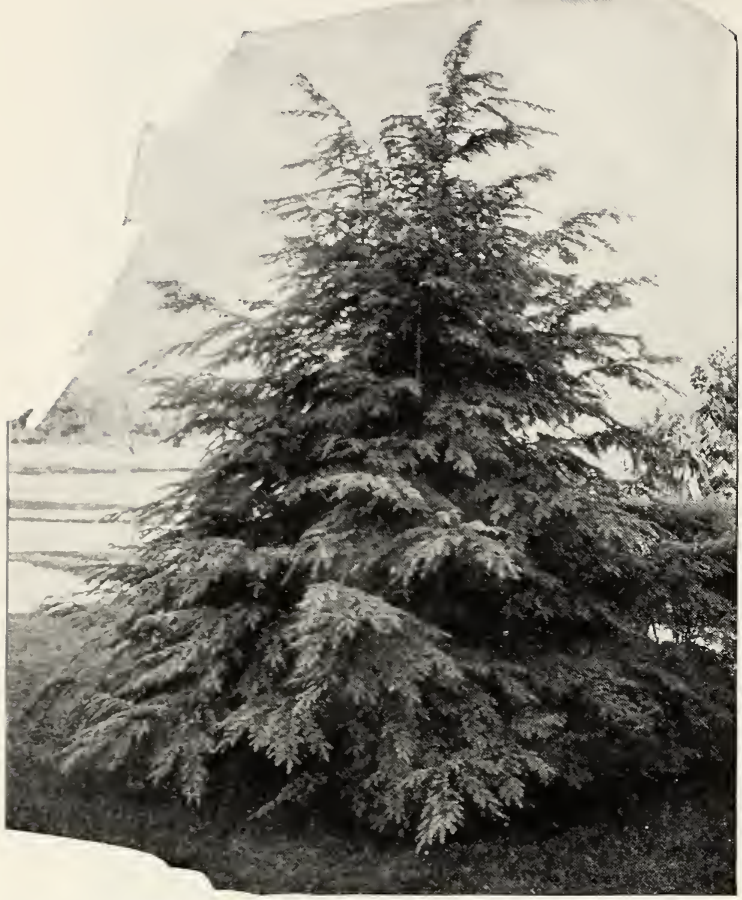

Hemlock. Most graceful and best beloved of American evergreens.

\section{TSUGA · Hemlock}

No doubt the Hemlock is the most graceful and the best loved of our native evergreens. A sight of one or a group of them, bending under the winter snow, is a picture never to be forgotten. They grow rapidly and in their early years are amenable to clipping and training, forming dense hedges or formal shapes. As they attain age, they form lofty, dignified trees of a magnificence equaled by few things in the world.

Tsuga canadensis. Common Hemlock. ( $\mathrm{Lr}$ ) No evergreen in our large collection is more lovely than the Hemlock. Its graceful branches sway with every breeze, making a charming picture whether planted singly or in a group. The Hemlock is the finest North American evergreen, and is always a source of joy and satisfaction to those who are wise enough to plant it freely. It makes a broadly pyramidal, medium-sized tree of dense growth, with rich green foliage and more or less drooping branches, giving a particularly graceful effect to the whole. It is excellent as a single lawn tree, for foundation planting when it is young, or for hedge purposes. Beautiful soft green the year round. Will not thrive in particularly bleak situations or near the salt water. We cut back our Hemlocks so that all the plants we offer are bushy and compact. 4 to $5 \mathrm{ft}$., $\$ 10$ each, $\$ 95$ for $10 ; 31 / 2$ to $4 \mathrm{ft}$., $\$ 8$ each, $\$ 75$ for 10 ; 3 to $31 / 2 \mathrm{ft}$., $\$ 6$ each, $\$ 55$ for $10 ; 21 / 2$ to $3 \mathrm{ft}$., $\$ 4.50$ each, $\$ 42$ for $10 ; 2$ to $21 / 2 \mathrm{ft}$., $\$ 3.50$ each, $\$ 33$ for 10 .

T. caroliniana. Carolina Hemlock. An attractive tree with dark green foliage and pendulous branches. A trifle more open and thin in growth and habit than the Common Hemlock. $4 \mathrm{ft}$., $\$ 10$ each; $3 \mathrm{ft}$., $\$ 6$ each, $\$ 57$ for $10 ; 2 \mathrm{ft}$., $\$ 4.50$ each, $\$ 42$ for 10 .

T. diversifolia. Japanese Hemlock. This variety has shorter foliage than the Canada or Common Hemlock and is very dwarf. It makes a dense mass of foliage and is a very desirable evergreen. 2 to $21 / 2 \mathrm{ft}$., \$6 each; 18 to 24 in., \$5 each, \$48 for $10 ; 15$ to 18 in., \$4 each, \$36 for 10 .

\section{Planting Suggestions}

AIl our evergreens are shipped with the roots in a ball of earth securely wrapped in burlap. It is important not to let this ball of earth become dry. When planting, be sure to dig a hole large and deep enough to receive ball without breaking or forcing. Remove the burlap before filling in with good soil. If the ground is dry, the hole should be partly filled with well-trodden earth and then filled with water. When the water has soaked in, put in more earth and more water, repeating the process until completed. If a slight depression is left about the base of the plant, it will help in future watering.

AIl newly planted evergreens should be made as firm as possible, that is, do not hesitate to tread the soil on the surface of the ground or to tamp it with a stick until it is very firm. PIanted in this way, the plant is well anchored and not likely to be loosened by strong winds or heaved out by frost.

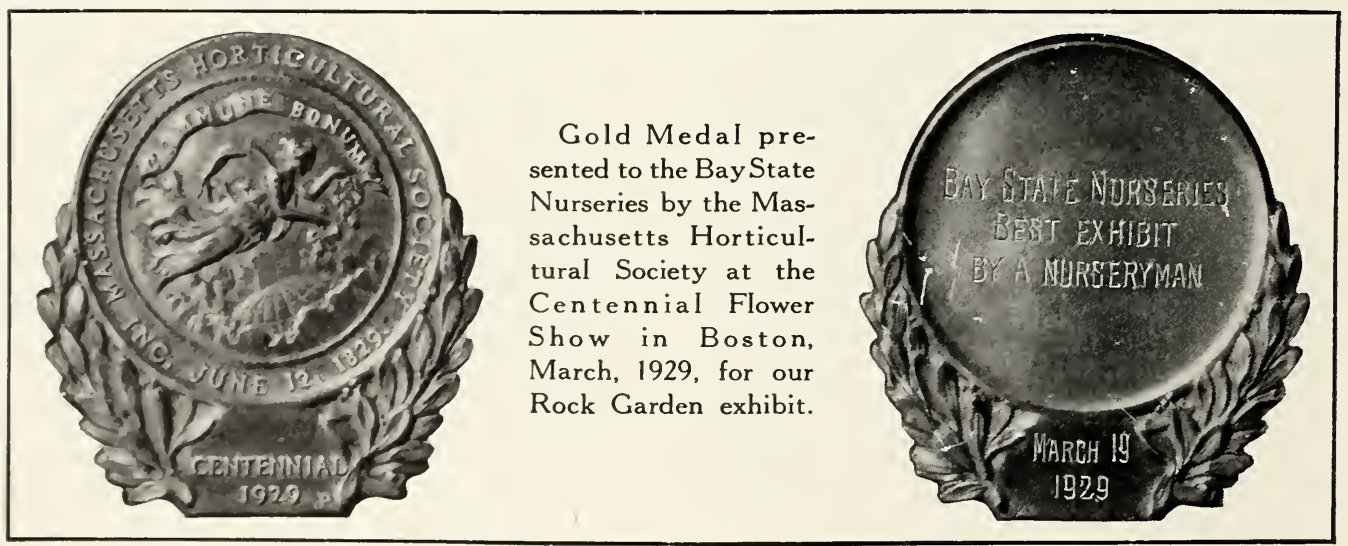




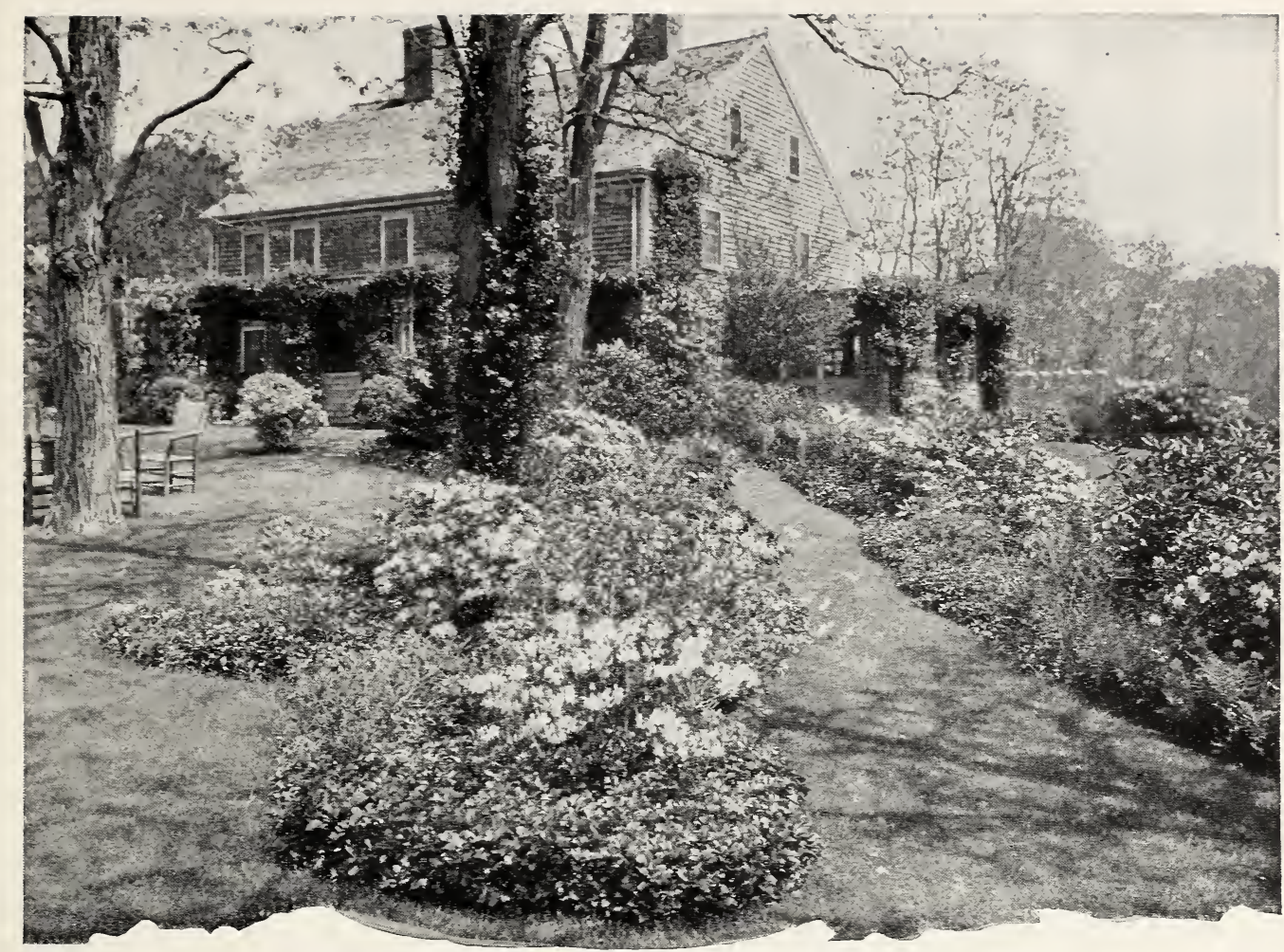

A group of Evergreen Shrubs, Azaleas and Rhododendrons making a maze of colorful cheer on the estate of Mr. C. O. Dexter, Sandwich, Mass.

\section{EVERGREEN SHRUBS}

A

GROUP of both small and large shrubs, with firm, hard leaves which are retained over winter. Most of them bloom beautifully, and some of them, the Rhododendrons and KaImias, are most showy, while others, Daphne, for example, are deliciously fragrant. They enjoy, as a rule, the light shade of nearby walls or trees, and thrive on a north slope where the winter sun does not damage their leaves, especially if slightly protected from hard, freezing winds. Most of them detest lime and should be grown in leaf-mold, mixed with peat, or some light soil not contaminated with lime or limestone.

\section{AZALEA}

Azalea amœna. Amœna Azalea. A dwarf, muchbranched shrub with double purplish red flowers in Mav. It is especially adapted for edging walks and garden borders. Should be planted in sheltered positions and will abundantly repay care and protection. Not likely to succeed in severe climates north of Boston. 18 to 24 in., \$4 each, \$36 for 10.

\section{BERBERIS - Barberry}

The Evergreen Barberries are among the handsomest plants in cultivation. They are compact and prickly and have a fine glossy sheen comparable to the hollies. The two varieties we offer are hardy and suffer little or no damage from the winter sun. Berberis verruculosa. Warty Barberry. The HollyIike Barberry would be a much better name for this charming dwarf plant, with curled, spined leaves of richest glossy green above but silvery white on the undersides. The flowers are yellow and fragrant and make a most delightful picture nestled among the dark foliage in spring. It likes a sheltered spot, growing beautifully in shade or sun, and can be used to advantage as a low hedge or edging to taller shrubs. We know of no more beautiful little shrub than this, and suggest that it be tried in shady spots in the rock garden or in any other situation where its yearround beauty can be enjoyed. 6 to 9 in., $\$ 1.50$ each, $\$ 13.50$ for 10

\section{BERBERIS, continued}

B. julianæ. Wintergreen Barberry. An erect plant of open habit, very different from the preceding. The willow-like leaves are larger, lighter green, and are sharply toothed and spined. The new shoots are soft, downy green, tinged with ruddy brown and bronze, which gives the growing plant a handsome color effect. It can be trimmed to make a dense bush of most attractive habit, and harmonizes well with rhododendrons, kalmias, and such other evergreen shrubs. We think it is a gem. 6 to 9 in., $\$ 1.50$ each, $\$ 13.50$ for 10 .

\section{BUXUS}

Buxus sempervirens suffruticosa. True Dwarf Box. A well-known dwarf edging plant, often used for bordering flower-beds. The plants we offer are very stocky. 10 to 12 in., B\&B, $\$ 1.60$ each, $\$ 15$ for 10 ; 8 to 10 in., B\&B, dense tops, $\$ 1.35$ each, $\$ 12.50$ for 10 ; 6 to 8 in., 50 cts. each, $\$ 4.50$ for $10, \$ 40$ per 100 .

\section{CALLUNA • Heather}

These plants should be more generally known. They are handsome, small shrubs of the easiest possible culture, weIl adapted to borders of evergreen shrubberies and for dry slopes and sandy banks; also growing well in ordinary soils. The varieties named herewith are hardy and bloom continuously from July to September. They are par- 


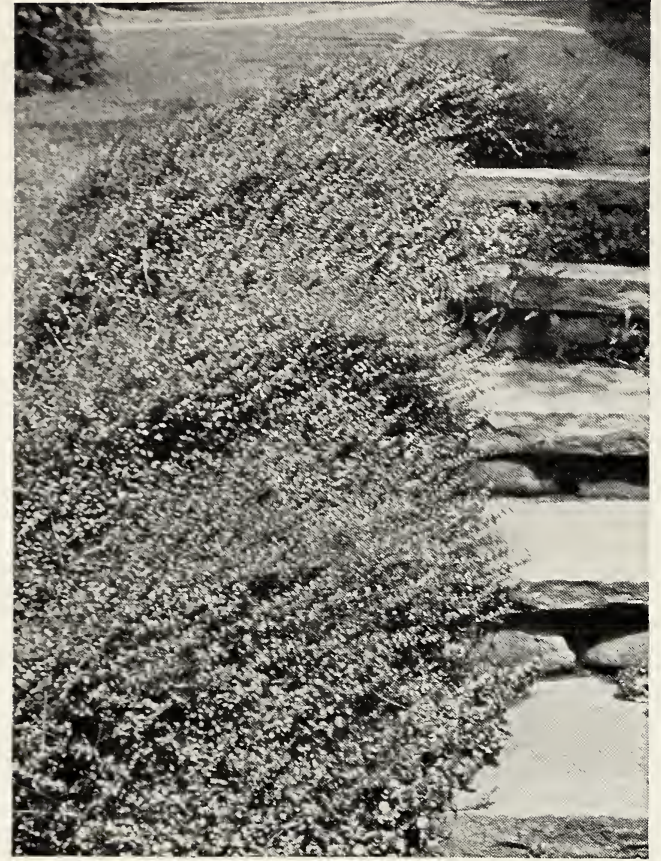

Euonymus radicans vegetus. Green all winter long.

CALLUNA, continued

ticularly desirable for rockeries, and although they prefer a sunny Iocation, they also grow in swamps and in partial shade. The cut branches last in good condition for many weeks.

We bave ten other varieties of Heatber wbicb are not described bere, and will be glad to send a list of them to anyone who is interested in this wonderful class of plants. Calluna vulgaris. Heatber. A low, bushy shrub, with tiny clustered leaves and slender, erect spikes of small pink flowers, which are borne profusely in Iate summer. Extremely pretty and quite unusual. 8 to 10 in., 90 cts. each, $\$ 8$ for $10 ; 6$ to 8 in., 75 cts. each, \$6 for 10.

C. vulgaris alba. White Heatber. Exactly like the preceding, except its flowers are white, and makes a charming combination with it either planted or cut. Prices same as Calluna vulgaris.

C. vulgaris alba elata. Tall White Heatber. Like the White Heather but taller and not so compact. Prices same as Calluna vulgaris.

C. vulgaris alporti. Alport Heatber. Of more vigorous growth than the common Heather and the flowers are rosy carmine. One of the best-liked varieties. 6 to 8 in., 75 cts. each, $\$ 6$ for 10 .

C. vulgaris aurea. Golden Heatber. Similar to the common Heather in habit, but its golden tinged foliage makes a lovely contrast with other varieties and in borders. 6 in., $75 \mathrm{cts}$. each, $\$ 6$ for 10.

C. vulgaris hammondi. Hammond's Heatber. A fine type of Pink-flowering Heather, which we think is more desirable in habit and profusion of bloom than the common $C$. vulgaris. 6 to 8 in., 75 cts, each, \$6 for 10.

C. vulgaris nana. Moss Heatber. A new sort which makes a small tuft or compact clump. The mossy foliage is dark green and most attractive. Especially good for rockeries. Clumps, 6 to 8 in., 90 cts. each, $\$ 8$ for $10 ; 4$ to 6 in., 75 cts. each, $\$ 7$ for 10 .

C. vulgaris rubra elata. Uprigbt Heatber. This is a tall, spreading sort, with deep rosy crimson flowers. A good companion for the Tall White Heather and as a background for the lower-growing varieties. 8 to 10 in., 90 cts. each, $\$ 8$ for $10 ; 6$ to 8 in., $75 \mathrm{cts}$. each, $\$ 6$ for 10 .

\section{CHAMADAPHNE • Leatherleaf}

Chamædaphne calyculata. Leatberleaf. Charming, low shrub for rockery or edge of shrub border. Heavy, evergreen leaves and slender, leafy racemes of drooping, wax-white flowers somewhat like those of Pieris. Very hardy. 12-in. plants, $\$ 1$ each, $\$ 9$ for 10 .

\section{ERICA • Heath}

Erica Tetralix. Cross-leafed Heath. A low, dense bush with grayish green foliage delicately fringed with silvery hairs. The pretty pink flowers are produced at the tips of the branches in summer and early autumn. A rare thing in this country and just made to nestle in a pocket against a noble rock. 6 to $8 \mathrm{in}$., 75 cts. each, $\$ 6$ for 10 .

\section{DAPHNE}

Daphne cneorum. Rose Dapbne. A dwarf evergreen shrub, which produces a profusion of delightfully fragrant rosy Iilac flowers in May and June, and on and off the rest of the summer. It is extremely pretty in evergreen borders and rock gardens, and is one of the choicest little plants grown. 8 to 10 in., $\$ 1.50$ each, $\$ 14$ for $10 ; 6$ to 8 -in. spread, $\$ 1$ each, $\$ 9$ for 10 , $\$ 80$ per 100 .

\section{EUONYMUS}

These are useful, glossy-leaved evergreen vines and low shrubs useful for covering tree trunks, walls, and, with proper training, they may be used as evergreen edgings to flower-beds, walks, and borders. It is well to shade them somewhat in late winter to prevent the sun from burning the leaves.

Euonymus radicans. Wintercreeper. A low, procumbent shrub, having small leaves, dull green above, with whitish veins. It will climb over a wall or up the side of a house and it makes a first-rate ground-cover. 3-yr. plants, 75 cts. each, $\$ 6$ for 10 ; 2 -yr. plants, 60 cts. each, $\$ 5$ for $10, \$ 40$ per 100 .

E. radicans argenteo-marginatus. Silveredge Wintercreeper. Similar to the preceding, with the leaves silvery at the edges, often becoming pinkish in the fall. Very attractive. 3-yr., 75 cts. each, $\$ 6$ for 10 .

E. radicans carrieri. Glossy Wintercreeper. A stronger grower than $E$. radicans, with larger, ovate, green leaves. It is half bush and half vine in habit of growth, and, if given support, makes a very fine covering for a building or a wall, and grows rapidly. Planted on either side of a walk, it may be kept low, to form an attractive little hardy evergreen hedge. 5 -yr., $\$ 2$ each, $\$ 18$ for $10 ; 4$-yr., $\$ 1.50$ each, $\$ 12.50$ for $10 ; 3$-yr., $\$ 1$ each, $\$ 8$ for 10 .

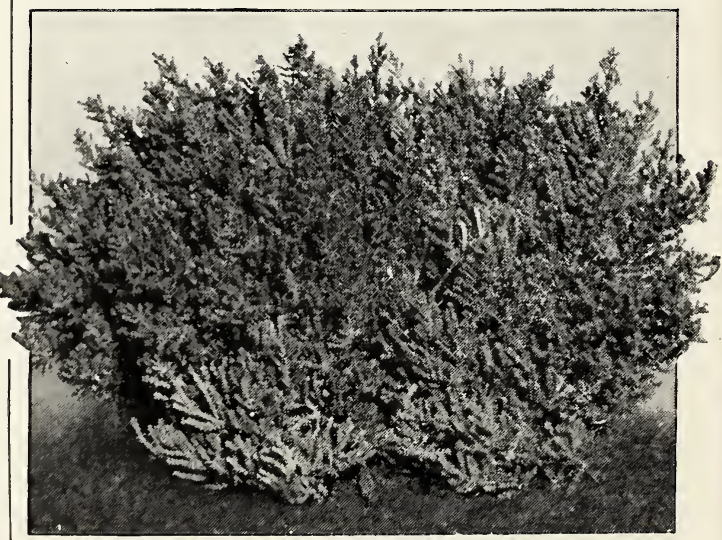

Calluna vulgaris nana. Makes a dense green carpet in the rock garden. 


\section{EUONYMUS, continued}

E. radicans colorata. Bronze Wintercreeper. A new variety introduced by the Arnold Arboretum, with bright red foliage during the winter months. A rapid grower. We suggest Euonimus radicans colorata as an interesting plant for its winter foliage. 4-yr. plants, \$1 each, \$9 for 10; 2-yr., 75 cts. each, \$6 for 10.

E. radicans minimus. Baby Wintercreeper. An excellent fine-leaved dark evergreen for carpeting the ground or as a rock plant. The smallest Euonymus. Very desirable. From 4 -in. pots, 75 cts. each, $\$ 6.50$ for 10 .

E. radicans vegetus. Bigleaf Wintercreeper. A trailing evergreen shrub with round leaves. Produces an abundance of orange-scarlet berries in the fall. Splendid for use as a ground-cover at the borders of evergreens. 4-yr., $\$ 1.50$ each, $\$ 13.50$ for 10 ; 3-yr., $\$ 1$ each, $\$ 8$ for $10 ; 2-y r ., 75$ cts. each, $\$ 6$ for 10.

\section{HEDERA • Ivy}

Hedera helix. Englisb Im. The rich dark green climber so well known in England. The leaves are characteristic. A strong climber which should grow on a sheltered wall. Easily the most beautiful wall covering, and worth taking care of. 4-in. pots, 75 cts. each, $\$ 6.50$ for 10.

H. helix gracilis. Small-leaved Englisb Ivr. Smaller foliage densely packed against the stems; very graceful, and will live over winter where the common English Ivy freezes out. From 4 -in. pots, 75 cts. each, $\$ 6.50$ for 10 .

\section{ILEX • Holly}

Ilex crenata microphylla. Small-leaved Japanese Holly. A dense, bushy shrub with tiny evergreen leaves which are as tough as Boxwood. The plant can be closely sheared and makes a splendid low hedge or edging for taller plants. 12 to 15 in., $\$ 4$ each, $\$ 36$ for 10.

I. glabra. Inkberry. A bushy, upright shrub with dark oval foliage, small flowers, and a profusion of back fruit in the fall. One of the best and hardiest of our native evergreens. 2-ft. clumps, $\$ 5$ each 18 -in. clumps, $\$ 3$ each; 15 -in. clumps, \$2.50 each; 12 -in. clumps, $\$ 1.50$ each, $\$ 14$ for 10.

\section{KALMIA · Laurel}

Either massed in groups or used as single specimens, the decorative effect of these splendid native shrubs is unequaled by any exotic plants of equal hardiness. They thrive in any soil which does not contain lime, although they are less sensitive in this respect than the rhododendrons.

Kalmia angustifolia. Lambkill. A handsome evergreen plant of moderate size, covered in the spring with purple and crimson flowers. Desirable for border planting or for rockeries. 18 in., $\$ 2.50$ each; 12 in., $\$ 1.50$ each.

K. latifolia. Mountain Laurel. A husky evergreen shrub, covered with I arge, glossy green Ieaves in clusters. It produces great quantities of delightful pink and white flowers the Iatter part of June. Perfectly hardy and will thrive equally well on dry knolls, low Iand, and in partial shade. One of the best native shrubs for naturalizing in suitable places. It is always desirable to plant it in groups or spreads of 6,12 , or 25 plants in order to get the effect of its magnificent sweep of color and mass. The Mountain Laurels we offer are all nursery grown. We will be pleased to quote prices on collected stock if interested in obtaining large quantities of this grade for landscape or other extensive use.

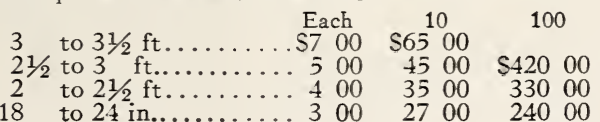

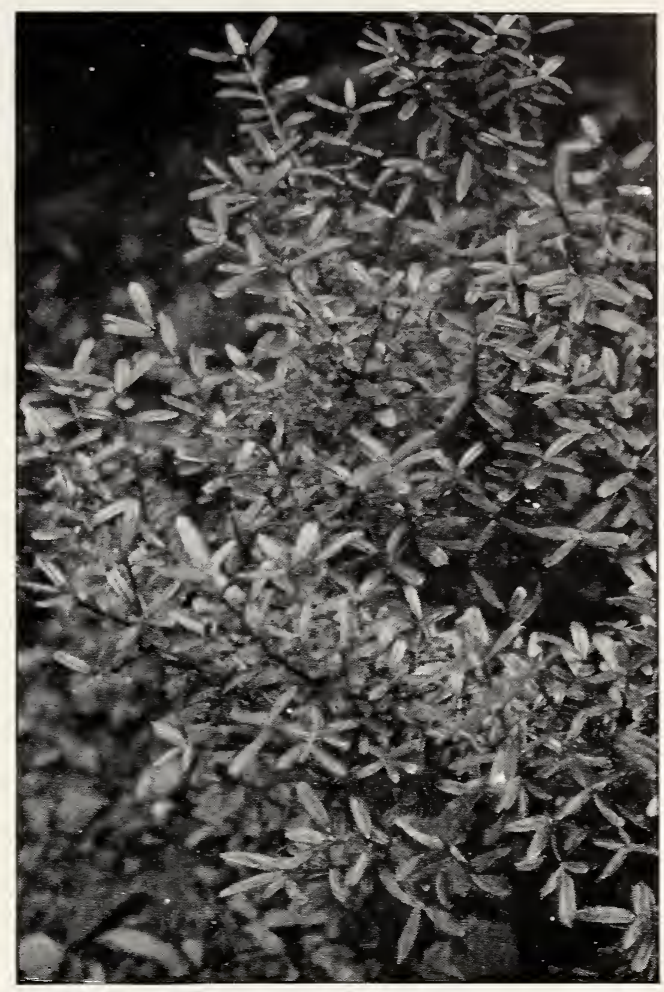

Pachistima canbyi. A rare little evergreen of great beauty.

\section{LEIOPHYLLUM}

Leiophyllum buxifolium prostratum. Allegbeny Sandmyrtle. A pretty little evergreen, suitable for edging. It has tiny leaves and little spravs of pink flowers in spring. A very charming plant which should be grown as a low edging or dividing-line. It wants a sour soil and a sunny, very well-drained site. 6 to 8 in., 90 cts. each, $\$ 8$ for 10 .

\section{LEUCOTHOE}

Leucothoe catesbæi. Drooping Leucotboe. A choice native evergreen shrub of great beauty. Its foliage is quite as charming as its blossoms, which are creamy white. The leaves are heavy, shining green in summer, and assume a beautiful purplish red tint late in the fall which is retained throughout the winter; branches arching. Superb for table decoration in winter. Very desirable for edging evergreens and rhododendrons. 15 to 18 in., $\$ 2.50$ each, $\$ 22.50$ for 10 ; 12 to 15 in., $\$ 2$ each, $\$ 18$ for 10 .

\section{MAHONIA}

Mahonia aquifolium. Oregon Hollygrape. A handsome evergreen shrub that is hardy in the North if planted in a sheltered position. Glossy green, hollylike leaves and yellow flowers in May. 18 to 24 in., 90 cts. each, $\$ 7.50$ for 10 ; 15 to 18 in., 75 cts. each, $\$ 6.50$ for 10 .

\section{PACHISTIMA}

Pachistima canbyi. Canby Pacbistima. A very low evergreen shrub, suitable for edging or rockery, making a dense, dark green carpet of great beauty. Flowers small, dark red. Give it a sour soil and a half-shady place. Field-grown plants, 6 to 8 in., 75 cts. each, $\$ 7$ for 10. 


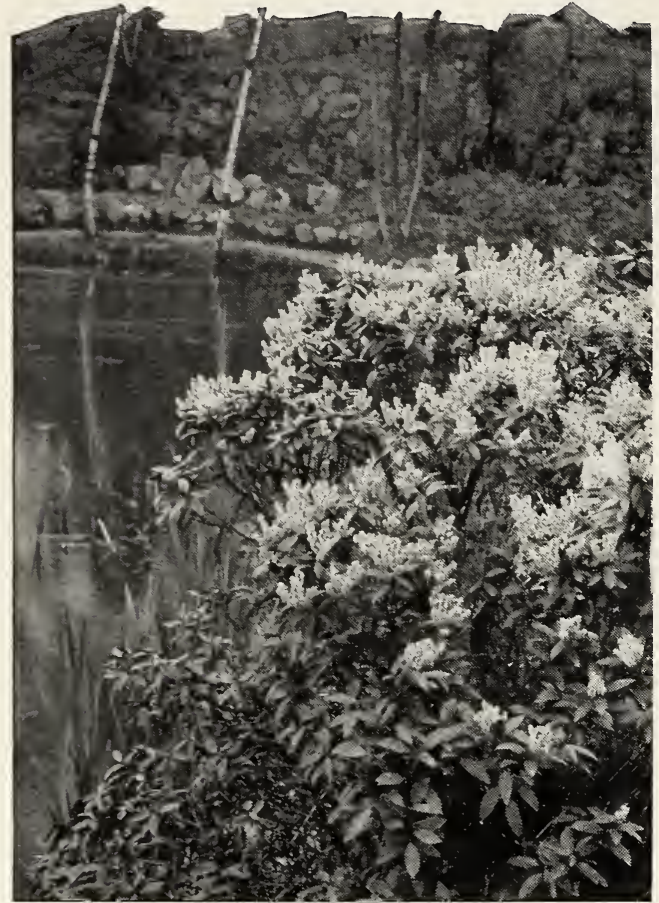

Pieris (Andromeda). One of the most ornamental shrubs both in and out of flower

\section{VINCA - Myrtle}

Vinca minor. Common Periwinkle. A handsome evergreen ground-cover with showy bright blue flowers borne freely in early spring and at intervals throughout the summer and autumn. It is perfectly hardy and does splendidly under trees or in shady nooks where few plants will thrive. Pot-grown or fieldgrown plants, 75 cts. for $3, \$ 2.20$ for $10, \$ 15$ per 100 .

\section{PIERIS • Andromeda}

Like the rhododendrons and IaureIs, the Andromedas are sour-soil plants and thrive in partial shade. They provide charming color-variation in their hairy stems and ruddy winter buds and are very graceful when in flower. We have a fine lot of bushy, well-grown plants of both varieties.

Pieris floribunda. Mountain Andromeda. White flowers in large panicles, like the lily-of-the-valley. The buds are produced in the fall, and open in early spring, over dense dark masses of evergreen foliage. Plant round, compact, and dwarf, very hardy. Excellent in evergreen foundation planting. There is no finer evergreen shrub than Mountain Andromeda. We urge you to plant one or more because we know you will not be disappointed. 2 to $21 / 2-\mathrm{ft}$. spread, $\$ 9$ each, $\$ 85$ for $10 ; 18$ to 24 -in. spread, $\$ 6$ each, $\$ 55$ for $10 ; 15$ to 18 -in. spread, $\$ 4$ each, $\$ 36$ for $10 ; 12$ to 15 -in. spread, $\$ 3$ each, $\$ 27$ for 10 .

P. japonica. Japanese Andromeda. One of the most beautiful, dwarf, broad-leaved evergreens, with bright green leaves and drooping racemes of waxy white flowers which make a beautiful contrast with the green foliage. The new foliage is most attractively tinged with rich bronzy red. A plant that is destinctly different and of great beauty, which will add dignity and charm to any garden. We recommend it highly. It should be planted in dry, sheltered positions. $21 / 2$ to $3 \mathrm{ft}$., $\$ 10$ each, 2 to $21 / 2 \mathrm{ft}$., $\$ 7$ each, $\$ 65$ for $10 ; 18$ to 24 in., $\$ 5$ each, $\$ 45$ for 10 .

\section{PACHYSANDRA}

Pachysandra terminalis. Japanese Pacbysandra. Low-growing evergreen plant with short spikes of white flowers in May and June. A splendid evergreen ground-cover, with attractive dark green leaves which make a rich mat of foliage in shady places where grass will not grow. A good border for beds of evergreens. It shows up especially well in winter when the grass is brown and the trees bare. Plant it thick, not over 6 inches apart each way to get it started well, and thin out later if necessary. Field-grown plants, $\$ 1.05$ for 3, $\$ 2.50$ for $10, \$ 18$ per 100 . From $2 \frac{1}{2}$-in. pots, 90 cts. for $3, \$ 2.20$ for 10 , $\$ 15$ per 100 .
SPECIALLY PREPARED PLANT FOOD

\section{VIGORO}

For Lawns, Gardens, Flowers, Shrubbery and Trees

A clean, safe, and very active fertilizer which really makes plants grow.

It is entirely inoffensive to handle,

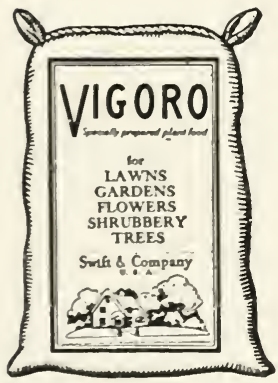

economical because of the small quantity required, and safe if used according to the directions sent with it.

Price $\$ 6$ per bag of $100 \mathrm{lbs}$.
Imported Granulated

\section{PEAT MOSS}

For making acid soil for Rhododendrons, Azaleas and other plants which require sour soil. A splendid mulch for roses and other plants, a great soil builder and fertilizer for lawns and shrubbery. Used extensively in seed beds and potting mixtures. Provides humus and great porosity, lightening heavy soils. Clean and economical.

Per bale $\$ 4$, f.o.b. North Abington

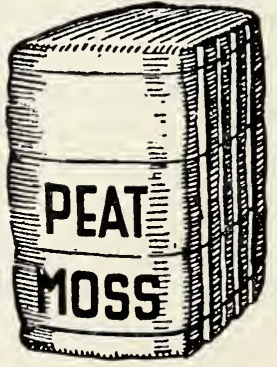




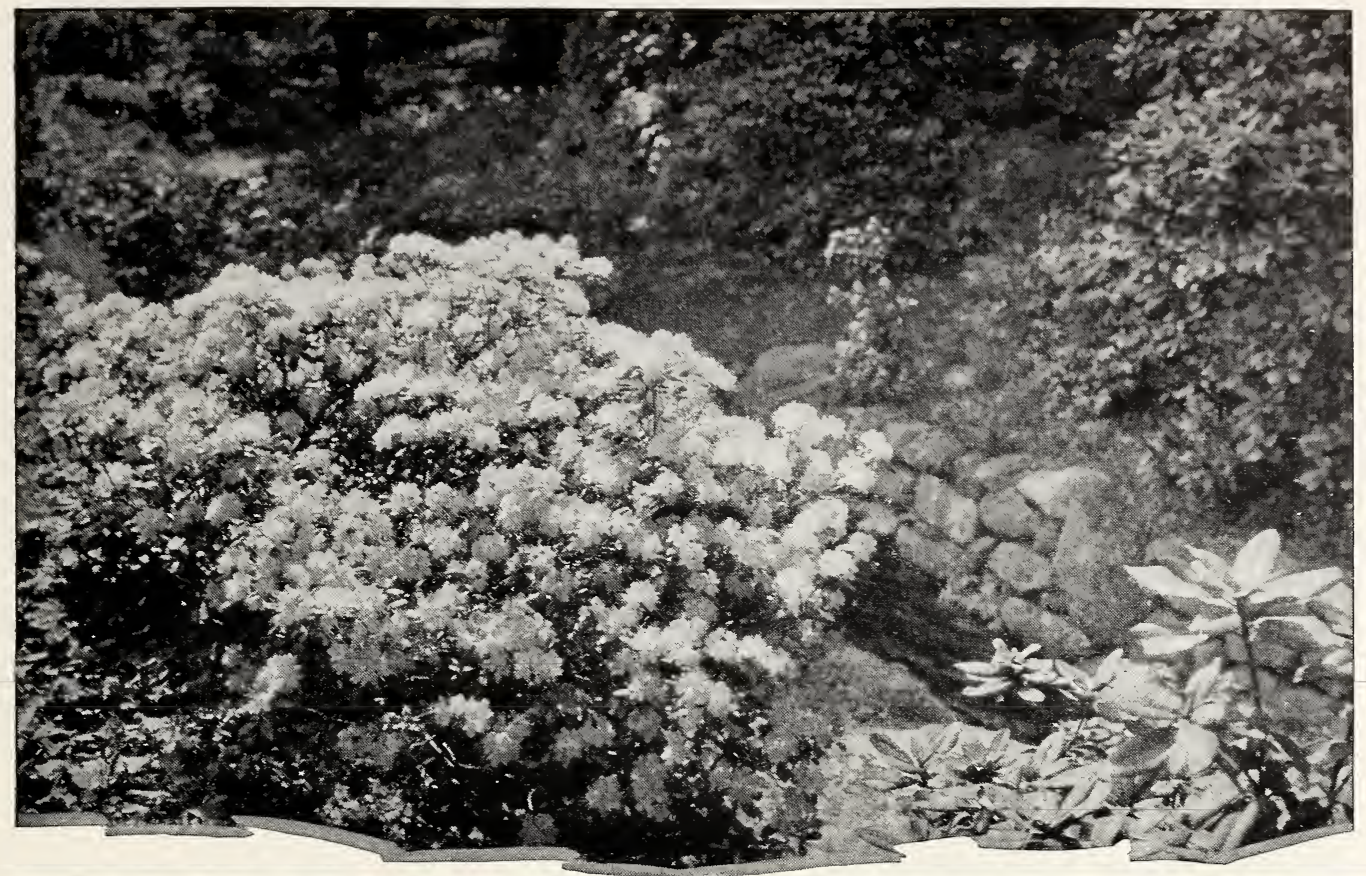

Rhododendron carolinianum, a mass of delicately colored flowers for weeks

\section{RHODODENDRONS}

$\mathrm{B}$

EYOND doubt, the handsomest evergreen shrubs. The beautiful, long, glossy leaves remain bright through the dark winter months, and their lovely clusters of flowers in early summer are miracles of delight. They should have thin shade, although they do well in full sunlight, and a north side of a waIl or building is especially adapted to them. They do demand plenty of water and soil absolutely free of lime. It will pay well to go to some trouble to make the soil for them decidedly sour. Groups of Rhododendrons dispersed in borders and under trees give untold return in the all-year beauty of their foliage and their lovely flowers in early summer. Blended with kalmias, andromedas, leucothoes, and other evergreen shrubs of varying habit, they provide scenes of diversified beauty and interest unrivaled by any other garden feature.

The American continent is peculiarly rich in these beautifuI shrubs, all of which are perfectly at home in our gardens, if their wishes in regard to sourness of soil and partial shade are respected. No hybrids have been raised from the showy tender species which surpass the original beauty of our native varieties, or equal them in vigor and hardiness. They are the most useful of all for general planting, particularly Rbododendron maximum which is the largest and showiest of the family. Tourists driving through the mountains of northern Pennsylvania are enthralled by the glorious beauty of this native shrub.

\section{Native Rhododendrons}

Rhododendrons are shipped with their roots in balls of earth wrapped in burlap and should be planted in the manner recommended for evergreens. The mulch is particularly important.

Rhododendron carolinianum. Carolina Rbododendron. One of the very finest broad-leaved evergreens, hardy in Massachusetts. It is four to six feet taII and as much in diameter; has handsome dark green leaves and blooms profusely. The clustered flowers are pale to deep pink, open before the young branches begin to grow and therefore are not hidden by them. It comes from the mountain tops of the southern Appalachian regions.

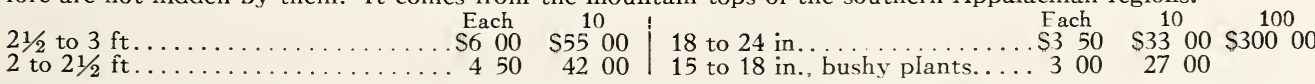

R. minus. Another native of the southern mountains. Under favorable conditions it makes a straggling shrub 10 feet high with handsome foliage and charming rosy pink flowers spotted yellow-green within. This is one of the very earliest of all to come into bloom and is very beautiful and satisfactory for extensive Iandscape planting. 2 to $21 / 2 \mathrm{ft}$., $\$ 5$ each, $\$ 45$ for 10 .

R. catawbiense. (Native.) Catawba Rbododendron. This is the parent of most of our best hybrids, and is worthy in every way. The flowers, borne profusely in very large, round trusses, come in various shades of lilac-purple the early part of June. It will grow in any soil where there is no lime, and needs no protection.
3 to $31 / 2 \mathrm{ft}$. . . .
\begin{tabular}{cc|cc} 
Each & 19 \\
$\$ 650$ & $\$ 6300$ & 2 to $21 / 2 \mathrm{ft}$
\end{tabular}
Fach 10
$21 / 2$ to $3 \mathrm{ft}$.

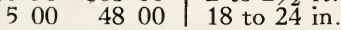
$\begin{array}{rrrr}\$ 4 & 00 & \$ 36 & 00 \\ 3 & 50 & 33 & 00\end{array}$

We can furnish bales of imported granulated peat moss. Ideal for mulching Rhododendrons, Azaleas, as well as all types of hardy plants, at $\$ 4$ each, $f . o . b$. North Abington, Mass. 


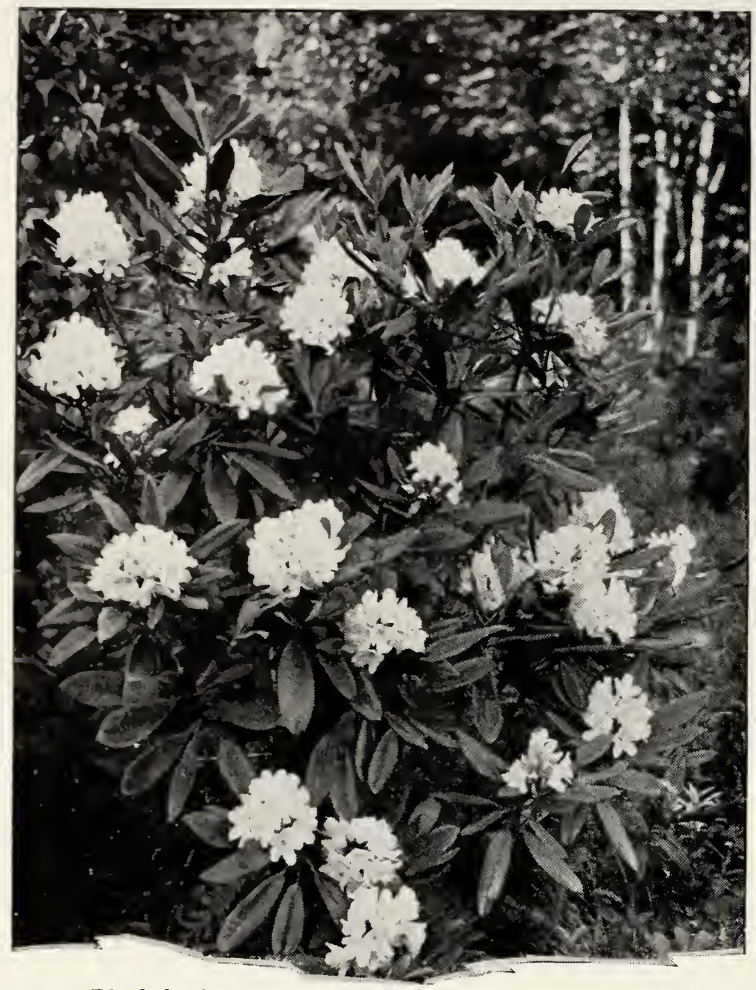

Rhododendron maximum. Biggest and boldest of native

Rhododendron maximum. (Native.) This is the handsome Great Laurel of the mountains. Flowers rosy white to white, produced in late June and July. Foliage very thick, smooth, and twice as large as that of any other sort. Handsome for big bold masses. Car-lots of collected plants can be furnished at much lower rates than the nursery-grown plants. These are exceptionally beavy plants.

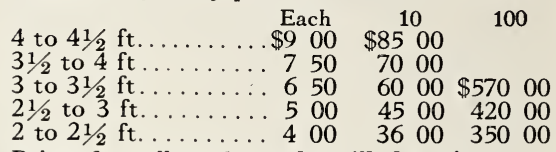

Prices for collected stock will be given on request.

\section{FOR THE OWNERS OF LARGE ESTATES}

We are supplying carload lots of Rhododendrons especially collected for us from the wild by experienced plantsmen whose careful selection and handling insure stock far superior to the usual run of collected plants. AII are heavy, bushy clumps. We shall gladly quote special prices on carload quantities of this fine collected stock. Write us in regard to quantities and sizes desired.

\section{HYBRID RHODODENDRONS}

Hybrid Rhododendrons are particularly celebrated for their very large clusters of handsome flowers and clear color. They are excessively rare in this country and therefore have great intrinsic value above their beauty, well-grown specimens having the value of old boxwood or other heirlooms. A solid planting of them is gloriously beautiful, and a few interspersed among a large group of the native sorts add distinction and variety to the planting.

We can supply a number of varieties of Hybrid Rhododendrons, particularly in shades of pink, lavender, and white. These are young, stocky plants ranging from 15 to 18 inches, and from 2 to $21 / 2$ feet, at prices from $\$ 7$ to $\$ 9$ each. Write for special quotations on named varieties.

We shall be glad to welcome visitors to our Nurseries at any time and shall be delighted to display the splendid plants of Rhododendrons which we have for sale. No one can see these magnificent plants without instantly desiring them, but whether one plant or hundreds are wanted, they are waiting for you here.

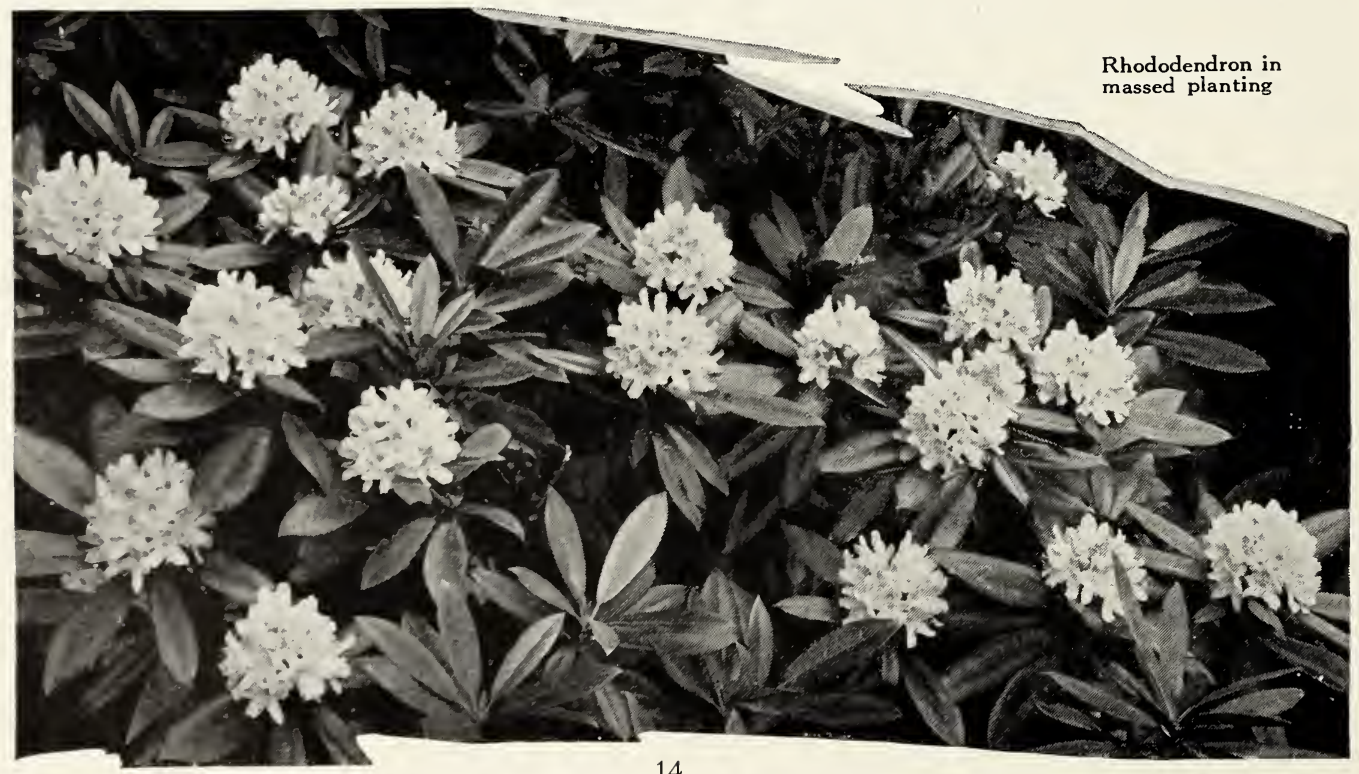




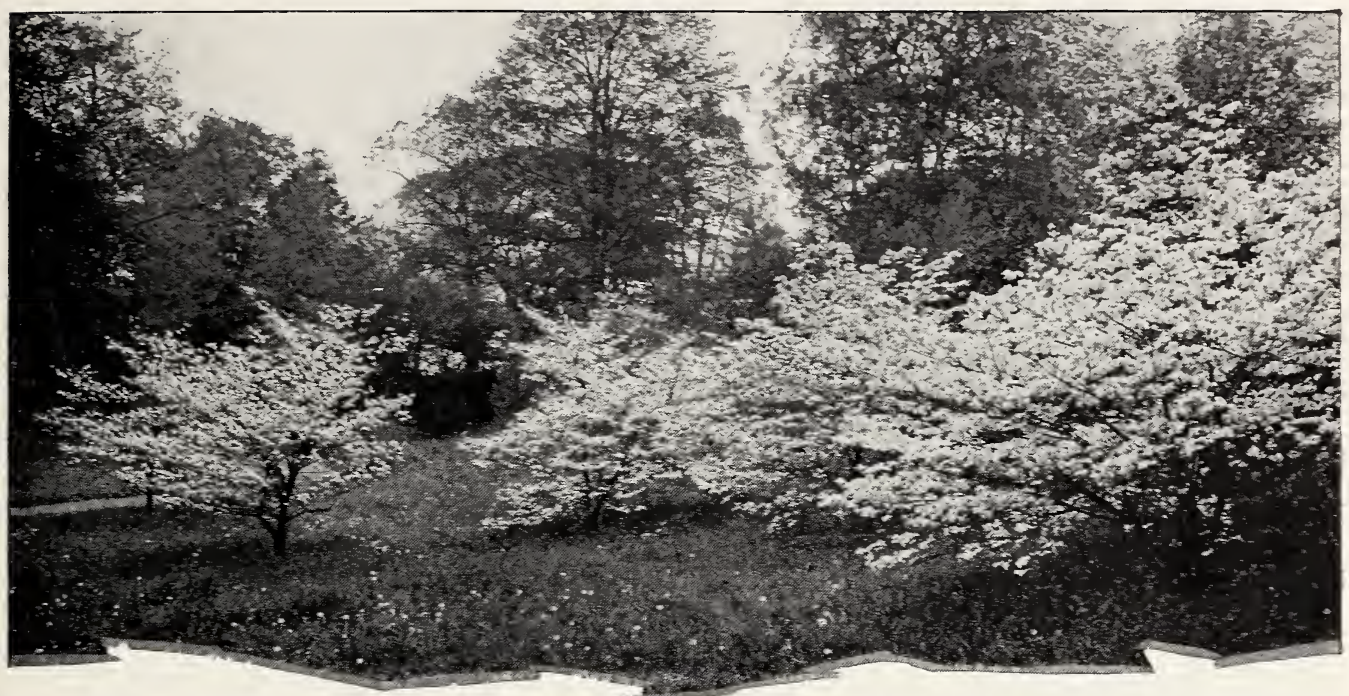

Cornus florida. The Dogwood, finest of American flowering trees, is perfectly happy at the edge of a woods or grove.

\section{DECIDUOUS TREES}

$\mathrm{T}$

HERE is a vast army of beautiful trees which shed their leaves in autumn. Among them are trees suitable for planting along streets and boundary lines, trees for woodlands and copses, for groves and for specimens, or merely to shade a corner of the back yard. Almost all of them are gorgeous when their leaves turn color in autumn and display an intricate and interesting pattern of bare branches against the winter sky.

Except that their roots are not balled and burlapped, the method of handling and planting them is the same as for evergreens. They should be weIl watered the first season and firmly staked so that they will not sway in the wind.

\section{ABBREVIATIONS}

Denoting Size: L, trees that attain a height of 50 feet or more; M, trees that attain a height of 25 to 50 feet; S, trees tha attain a height of 10 to 25 feet; D, dwarf; VD, very dwarf.

Denoting Rapidity of Growth: r, rapid; m, medium; s, slow; v, vigorous; vs, very slow.

Denoting Varieties Suitable for Seashore Planting: $(\dagger)$.

\section{ACER - Maple}

The Maples are too familiar to need much introduction. They are all splendid, round-headed trees, some of which are especially adapted to street planting, and all of them are desirable as specimens.

Acer dasycarpum. Silver Maple. (Lr) Foliage light green, silvery beneath. A most rapid-growing Maple thriving best in rich, moist soil but succeeding almost anywhere except on dry ground. Largely used for street planting. 12 to $14 \mathrm{ft}$. $\$ 4$ each, $\$ 36$ for 10 ; 10 to $12 \mathrm{ft}$., $\$ 3$ each, $\$ 27$ for $10 ; 8$ to $10 \mathrm{ft}$., $\$ 2$ each.

A. ginnala. Amur Maple. (Dm) Graceful shrub or small tree, with handsome foliage that turns bright red in autumn. Useful as substitute for the Japanese Maple where that is not hardy. 6 to $8 \mathrm{ft} ., \$ 2.50$ each, $\$ 22.50$ for $10 ; 5$ to $6 \mathrm{ft}$., $\$ 2$ each, $\$ 17.50$ for 10 .

A. negundo. Boxelder. (Mr) A rapid-growing tree that is useful where a quick screen is desired. It has spreading branches and light green foliage that changes to yellow in the autumn. Although it thrives best in rich, damp ground, it will grow in dry or poor soils. 12 to $14 \mathrm{ft}$., $\$ 3.25 \mathrm{each} ; 10$ to $12 \mathrm{ft}$., $\$ 2.50$ each; 8 to $10 \mathrm{ft}$., $\$ 2$ each, $\$ 17.50$ for 10 .

A. palmatum. Japanese Maple. (Dm) A handsome shrub of dense, graceful habit, with especially attractive foliage in spring and fall, when it assumes most striking colors. Suitable for individual planting. 3 to $4 \mathrm{ft}$., $\$ 3.50$ each; 2 to $3 \mathrm{ft}$., $\$ 2.50$ each, $\$ 22.50$ for 10 .

\section{ACER, continued}

A. palmatum atropurpureum. Blood-leared Japanese Maple. (Ds) A very striking tree in spring when its leaves are blood-red; later they change to dark purple, retaining this attractive color throughout the season. This small tree is often used on lawns but is most effective when contrasted with evergreens. In New England it should be planted only in sheltered places. $3 \mathrm{ft}$., $\$ 9$ each; $21 / 2 \mathrm{ft}$., $\$ 7.50$ each; $2 \mathrm{ft}$., $\$ 6$ each; 18 in., $\$ 4$ each.

†A. platanoides. Norway Maple. (Lr) This Iarge, handsome tree has a round, spreading head and broad, dark green foliage. It is decidedly beautiful when covered with its golden blossoms, before the foliage appears. The hardiest of all Maples, and will withstand extreme exposure; especially adapted for street, shade, and seashore planting. 10 to $12 \mathrm{ft}$., $\$ 5$ each, $\$ 48$ for $10 ; 8$ to $10 \mathrm{ft}$., $\$ 4$ each, $\$ 37.50$ for 10 ; 6 to $8 \mathrm{ft}$., $\$ 2.75$ each, $\$ 25$ for 10 .

A. platanoides schwedleri. Scbwedler Maple. (Mr) The leaves are bright red when they first appear, changing later in the season to dark purplish green. Like the Norway Maple in habit of growth. 6 to 8 ft., $\$ 5$ each, $\$ 45$ for 10 .

A. rubrum. Red Maple. (Lv) A very popular variety because of its irregular habit which is much appreciated independent of its other remarkably fine qualities of growt $\bar{h}$, its fragrant, scarlet flowers in early spring, and dense foliage which assumes a gorgeous color in autumn. Thrives in wet situations where no other Maple will live. 10 to $12 \mathrm{ft}$., $\$ 5 \mathrm{each}$, $\$ 45$ for $10 ; 8$ to $10 \mathrm{ft}$., $\$ 3.50$ each, $\$ 33$ for $10 ; 6$ to $8 \mathrm{ft}$., $\$ 2.75$ each, $\$ 25$ for 10 . 


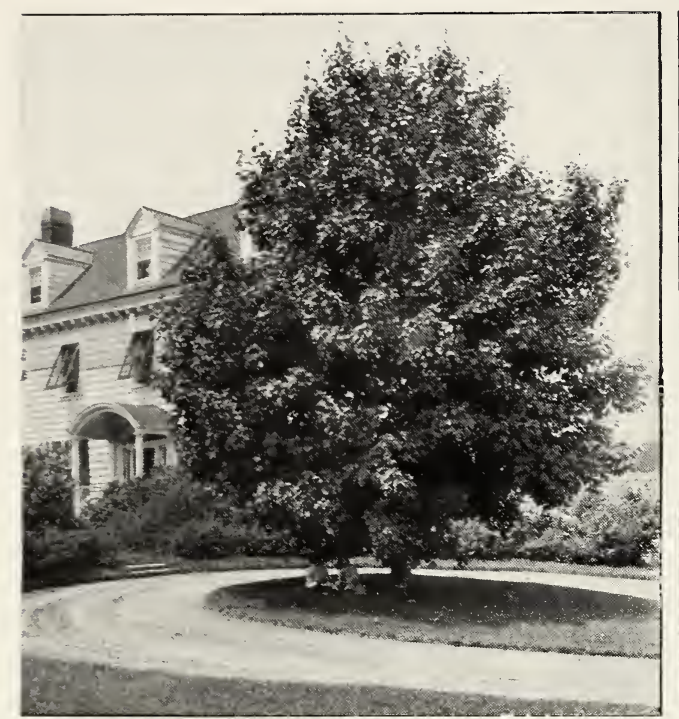

Norway Maple. A handsome, enduring tree for city use.

ACER, continued

A. saccharum. Sugar Maple. (Lr) An excellent street and shade tree, somewhat higher headed than the Norway Maple, with dense foliage that turns bright yellow and scarlet in autumn. Does well in almost any soil. 10 to $12 \mathrm{ft}$., $\$ 5$ each; 8 to $10 \mathrm{ft}$., $\$ 3.50$ each, $\$ 33$ for $10 ; 6$ to $8 \mathrm{ft}$., \$2.50 each, \$24 for 10 .

A. tataricum. Tatarian Maple. (Dm) A hardy and desirable shrub-like tree with brilliant autumn coloring. 10 to $12 \mathrm{ft}$., $\$ 2.75$ each, $\$ 25$ for $10 ; 8$ to $10 \mathrm{ft}$., \$2.25 each, \$21 for 10 .

\section{ÆSCULUS - Horsechestnut}

Esculus hippocastanum. European Horsechestnut. (Lm) A large tree of regular outline with attractive foliage. In May it bears a profusion of very showy white flowers tinged with red, in 8 to 10 -inch panicles. These are followed by fruits an inch or more in diameter. 5 to $6 \mathrm{ft}$., $\$ 2.50$ each; 4 to $5 \mathrm{ft}$., $\$ 2$ each.

\section{AILANTHUS}

Ailanthus glandulosa. Ailanthus. (Lr) Valuable for street planting where other trees do not thrive, as it withstands smoke and dust well. It is an extremely rapid-growing, open-headed tree with palm-like foliage and greenish flowers in June. 8 to $10 \mathrm{ft}$., \$3 each, \$27 for $10 ; 6$ to $8 \mathrm{ft}$., $\$ 2.50$ each, $\$ 22.50$ for $10 ; 5$ to $6 \mathrm{ft}$., $\$ 2$ each, $\$ 18$ for 10 .

\section{ARALIA · Angelica Tree}

Aralia spinosa. Devils-walkingstick. (Dr) Its stout stems, covered with thorns, immense leaves, and enormous clusters of small white flowers, followed by purple berries, give this species a very distinct subtropical appearance. 8 to $10 \mathrm{ft}$., $\$ 2$ each, $\$ 17.50$ for $10 ; 6$ to $8 \mathrm{ft}$., $\$ 1.50$ each, $\$ 14$ for $10 ; 5$ to $6 \mathrm{ft}$., $\$ 1.20$ each, $\$ 10$ for 10 .

\section{BETULA • Birch}

This is a small family of trees with a grace and charm all their own. Mostly used as lawn specimens or in effective positions upon the grounds; they are also splendid mingled with other varieties in an open woodland, and the light-barked kinds are beautifui grouped at the edge of a thicket or forest.

\section{BETULA, continued}

$\lceil$ Betula alba. European White Bircb. (Mr) A tall, graceful tree, with spray-like branches and silvery bark that is very effective in winter. It assumes an elegant, drooping habit, and is a desirable Iawn tree. Does well in poor soils. 8 to $10 \mathrm{ft}$., $\$ 3$ each, $\$ 27$ for 10 ; 6 to $8 \mathrm{ft}$., $\$ 2.50$ each, $\$ 22.50$ for 10 ; 5 to $6 \mathrm{ft}$., $\$ 2$ each, $\$ 18$ for 10 .

B. lutea. Yellow Birch. (Lr) Bark is silvery gray or light orange; leaves hairy along the veins beneath; one of the most valuable forest trees in the Northern States. A blaze of gold in the autumn. 5 to $6 \mathrm{ft}$., $\$ 2$ each.

$\dagger$ B. papyrifera. Canoe Birch. (Lr) A worthy ornamental tree. When young, the stem is dark brown (sometimes almost black), which causes many people to question the variety, but as it develops, the trunk becomes white, with a loose, graceful head and Iarge, handsome I eaves. It thrives well in northern latitudes and is very effective when planted in a group. 6 to $8 \mathrm{ft}$., $\$ 2.50$ each, $\$ 22.50$ for $10 ; 5$ to $6 \mathrm{ft}$. $\$ 2$ each, $\$ 18$ for 10 .

B. pendula gracilis. Cutleaf Weeping Bircb. (Mm) An unusually graceful, drooping tree, particularly adapted to lawns. The foliage is deeply cut and the bark silvery white at maturity. A vigorous grower in rich, moist ground. 10 to $12 \mathrm{ft}$., $\$ 6$ each; 8 to 10 $\mathrm{ft}$., $\$ 5$ each, $\$ 45$ for $10 ; 6$ to $8 \mathrm{ft}$., $\$ 4$ each, $\$ 36$ for 10 .

†B. populifolia. Gray Birch. (Mr) A slender tree with smooth, grayish white bark and glossy leaves It is a rapid grower and thrives in dry and poor soil. but is not a particularly desirable tree. 8 to 10 $\mathrm{ft}$., $\$ 1.75$ each, $\$ 15$ for $10 ; 6$ to $8 \mathrm{ft}$., $\$ 1.50$ each, $\$ 14$ for 10 ; clumps, 6 to $8 \mathrm{ft}$., $\$ 4$ each.

\section{CATALPA - Indian Bean}

Useful trees with very Iarge leaves and extremely handsome flowers. They grow rapidly and quickly, making a grateful shade. Well adapted to avenue planting, and the first variety named is highly popular for certain formal effects.

Catalpa bignonioides nana (bungei). Umbrella Catalpa. (Dm) A species from China that has Iarge, glossy foliage and is a shy bloomer. If the top is grafted on tall stems, it makes an effective tree for formal gardens, not too far north. 2-yr. heads, $\$ 2.50$ each, $\$ 22.50$ for 10 .

C. speciosa. Western Catalpa. (Lr) This tall, hardy variety is well adapted to forest and ornamental planting. The most desirable Catalpa. 12 to $14 \mathrm{ft}$., $\$ 2.50$ each, $\$ 22.50$ for $10 ; 10$ to $12 \mathrm{ft}$., $\$ 2$ each, $\$ 18$ for $10 ; 8$ to $10 \mathrm{ft}$., $\$ 1.50$ ea.ch, $\$ 14$ for 10 .

\section{CELTIS - Nettle Tree}

†Celtis occidentalis. Hackberry. (Mm) Rare native tree with numerous slender branches and light green, shiny leaves. The bark is thick and rough. Resembles the elm. 8 to $10 \mathrm{ft}$., $\$ 3$ each; 6 to $8 \mathrm{ft}$., $\$ 2$ each.

\section{CERCIDIPHYLLUM · Katsura Tree}

Cercidiphyllum japonicum. Katsura Tree. (Mr) This hardy ornamental tree is of pyramidal form, with medium-sized, heart-shaped leaves dark green above and silvery beneath, while the leaf-stalks and vines are purplish. It branches to the ground, and prefers damp soil, where it grows rapidly. Should be planted either as a specimen or in borders. 12 to $14 \mathrm{ft}$., $\$ 8$ each; 10 to $12 \mathrm{ft}$., $\$ 6$ each; 6 to $8 \mathrm{ft}$., $\$ 4$ each, $\$ 36$ for 10 .

\section{CERCIS - American Redbud}

Cercis canadensis. American Redbud. (Ss) One of the finest ornamental trees. It is of medium size, round-headed, with Iarge, heart-shaped, leathery dark green foliage. A profusion of deep pink flowers covers the tree in April before the leaves appear. 5 to $6 \mathrm{ft}$., $\$ 2.50$ each, $\$ 22.50$ for $10 ; 4$ to $5 \mathrm{ft}$., $\$ 1.50$ each, \$14 for 10 . 


\section{CHIONANTHUS - Fringe Tree}

Chionanthus virginica. White Fringe Tree. (Sv) A superb Iawn tree, with large, dark green foliage and white fringy flowers in early summer. 6 to $7 \mathrm{ft}$., $\$ 5$ each, $\$ 48$ for $10 ; 5$ to $6 \mathrm{ft}$., $\$ 4$ each, $\$ 36$ for 10 ; 4 to $5 \mathrm{ft}$., \$3 each, \$27 for 10 .

\section{CORNUS · Dogwood}

Small trees desirable from every point of view. In the spring they make a picture of unforgettable beauty with their drifts of snowy flowers against the sky or a background of evergreens. Their rich green foliage is handsome during the summer, and their glittering red berries are one of autumn's chiefest charms.

Cornus florida. Wbite-flowering Dogwood. (Sv) An American species of regular habit, with spreading, open top. It produces Iarge, showy white flowers in May before the leaves appear. In autumn the gravish green foliage turns dark red, and with the brilliant red berries makes it one of the most beautiful trees at that season. 5 to $6 \mathrm{ft}$., B \& B, \$5 each, $\$ 48$ for $10 ; 4$ to $5 \mathrm{ft}$., B \& B, \$3 each, \$27 for $10 ; 3$ to $4 \mathrm{ft}$., \$2 each, \$18 for 10 .

Note.-B\&B means roots taken up with earth and burlapped, for which no extra charge is made.

C. florida rubra. Red-flowering Dogwood. (Sv) One of the finest flowering trees. It blooms when quite young, producing deep, rose-colored flowers in the early spring. This tree is worthy of extensive culture and should have a place on every sizable lawn. 4 to $5 \mathrm{ft}$., B\&B, $\$ 7.50$ each; 3 to $4 \mathrm{ft}$., B\&B, $\$ 6$ each.

\section{CRAT EGUS · Hawthorn}

The Thorns are small, shrubby trees, charming alike when bare, in flower, in foliage, or in fruit. They are fine for masses in the corners or at boundaries, and look well in hollows or along streams, fitting into almost any scheme of naturalistic or formal planting.

†Cratægus coccinea. Tbicket Hautborn. (Ss) A fine native variety with large foliage and white blossoms in May, succeeded by scarlet fruit. 4 to $5 \mathrm{ft}$., S2 each, $\$ 18$ for $10 ; 3$ to $4 \mathrm{ft}$., $\$ 1.50$ each, $\$ 14$ for 10 . $\dagger$ C. cordata. Wasbington Hawtborn. (Sm) Very desirable, with beautiful autumn color and large clusters of bright red fruit, remaining on the branches a long time. Much used both singly and in groups. 3 to $4 \mathrm{ft}$., $\$ 2$ each, $\$ 18$ for $10 ; 2$ to $3 \mathrm{ft}$., $\$ 1.50$ each, $\$ 14$ for 10

†C. crusgalli. Cockspur Thorn. (Dv) The long, sharp thorns and glossy green foliage, which turns brilliant orange and scarlet in the fall, make this a valuable variety for hedges. 4 to $5 \mathrm{ft}$., $\$ 2.50$ each, $\$ 22.50$ for $10 ; 3$ to $4 \mathrm{ft}$., $\$ 1.75$ each, $\$ 16$ for 10 .

C. oxyacantha splendens. Paul's Double Scarlet Hawtborn. (Sm) A small tree of fine habit, with rich, luxuriant foliage and very double deep crimson flowers with a scarlet glow. 5 to $6 \mathrm{ft}$., $\$ 3.50$ each; 4 to $5 \mathrm{ft}$., $\$ 3$ each.

\section{FAGUS · Beech}

Beeches are among the noblest trees of creation, Iong-lived, symmetrical, and beautiful at all seasons of the year. They make dense shade and thick dark woods. The colored-leaf forms are among the finest ornamentals for specimen or avenue work. Beeches resent transplanting to some extent, therefore we ship them with the roots carefully balled and burlapped.

Fagus americana. American Beecb. (Lv) Large, spreading tree of symmetrical habit. Its rich yellow autumn foliage and smooth, gray bark add to its attractiveness. 5 to $6 \mathrm{ft}$., $\$ 5$ each; 4 to $5 \mathrm{ft}$., $\$ 4$ each.

\section{FAGUS, continued}

F. sylvatica purpurea. Purple Beecb. (Lv) Th foliage of this low-branching tree is very attractive In spring it is bright reddish purple, turning beautiful purple-tinged green in summer. It forms a noble, symmetrical head of majestic appearance, and its foliage has a brilliant metallic glitter in the sunshine, which makes the tree conspicuous in the landscape, even at great distances. Splendid for a lawn tree. 16 to $20 \mathrm{ft}$., B\&B, \$30 each.

Note. - B\&B means roots taken up with earth and bur Iapped, for which no extra charge is made to the purchaser.

\section{FRAXINUS • Ash}

The Ashes grow quickly and thrive in almost any moist soil. They are valuable for parks and landscapes, and make good street trees in many localities.

Fraxinus americana. Wbite Asb. (Lv) This wellknown native variety has a straight, clean trunk and soft, mellow green foliage, changing in the autumn to rich brown. A desirable shade or street tree because it furnishes shade quickly and is comparatively long-lived. 6 to $8 \mathrm{ft}$., $\$ 1.50$ each, $\$ 14$ for 10 .

\section{GINKGO • Maidenhair Tree}

Ginkgo biloba. Maidenbair Tree. (Mr) This beautiful tree is of upright habit, with a clean, straight trunk and spreading branches peculiar to itself. The leaves are fan-shaped, resembling the maidenhair fern, and in the fall become rich golden yellow. An excellent lawn and avenue tree and very satisfactory in cities. Insects avoid it. A very ancient Chinese tree come down from prehistoric time. It has never been found growing wild but always in gardens or under the protection of man. It has been truly and aptly described as a living fossil. 6 to $8 \mathrm{ft}$., $\$ 4$ each.

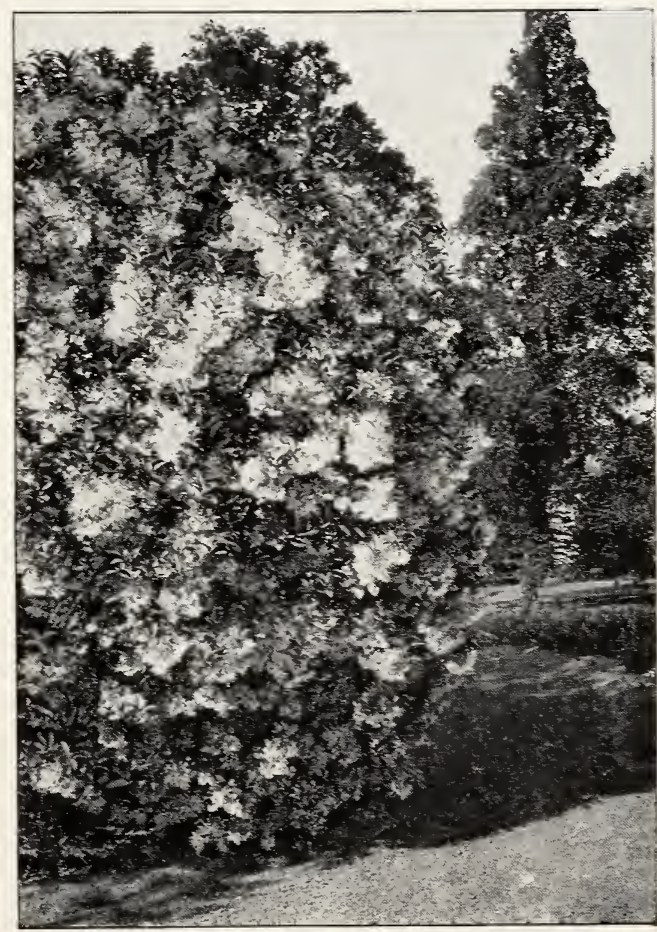

Chionanthus virginica. A charming, graceful little tree for borders and shrubbery. 


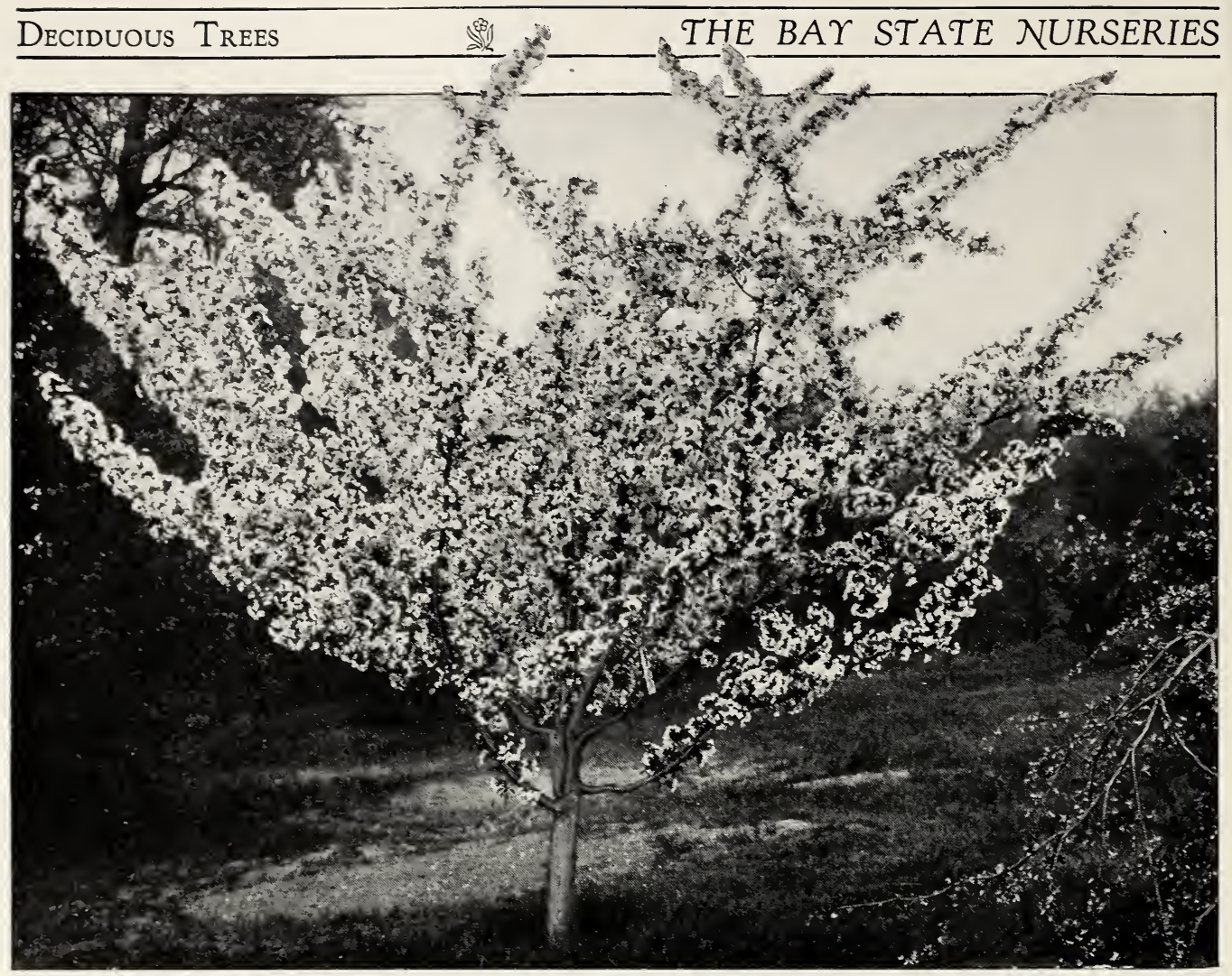

Malus theifera. The Tea $\mathrm{Crab}$ is the most floriferous and spectacular of the Flowering Apples

\section{GLEDITSIA • Honey Locust}

†Gleditsia triacanthos. Common Honey Locust. (Lv) A rapid-growing tree that is armed in the earlier stages with powerful spines and has foliage of delicate appearance. It makes a stately specimen or is useful when a tall hedge is desired. The wood is known for its long-enduring qualities. 6 to $8 \mathrm{ft}$., $\$ 1.50$ each, $\$ 12$ for $10 ; 5$ to $6 \mathrm{ft}$., $\$ 1.25$ each, $\$ 10$ for $10 ; 4$ to $5 \mathrm{ft}$., $\$ 1$ each, $\$ 8$ for 10 .

\section{GYMNOCLADUS}

Gymnocladus dioica. Kentuckv Coffee Tree. (Mm) A fine native tree of irregular shape, with bluish green, feathery foliage. Useful either on the lawn or in a border. 6 to $8 \mathrm{ft}$., $\$ 2$ each; 5 to $6 \mathrm{ft}$., $\$ 1.75$ each.

\section{JUGLANS • Walnut}

The once familiar Butternut and Walnut are becoming scarcer in the wild every year. They make picturesque Iawn trees and handsome groves. Their nuts are highly valued and their wood is almost priceless. One of the most worthy groups of native trees, and they should be planted liberally.

Juglans cinerea. Butternut. (Lm) A vigorous, native, open-headed tree, with grayish, rough bark, and foliage that resembles that of the ailanthus. Valued for its nuts, as well as for its ornamental appearance. 8 to $10 \mathrm{ft}$., $\$ 2.50$ each, $\$ 22.50$ for 10 ; 6 to $8 \mathrm{ft}$., $\$ 2$ each, $\$ 18$ for 10 .

J. nigra. Black Walnut. (Lr) This native tree is of majestic size and graceful habit, with dark brown bark and beautiful foliage. Valuable for lumber in regions where it flourishes. We do not recommend planting it north of Boston. 10 to $12 \mathrm{ft} ., \$ 3 \mathrm{each}$, $\$ 27$ for $10 ; 8$ to $10 \mathrm{ft}$., $\$ 2.50$ each, $\$ 24$ for 10 .

\section{KELREUTERIA}

Kœlreuteria paniculata. Golden Rain Tree. A very ornamental, round-headed tree with handsome, light green foliage and large clusters of small yellow flowers. Very decorative. 5 to $6 \mathrm{ft}$., \$3 each.

\section{LABURNUM • Golden Chain}

Laburnum vulgare. Golden Cbain. (Sm) A small tree with smooth foliage, deriving its name from the long racemes of golden yellow blossoms produced in June. It does best in a cool, shady spot. 3 to $4 \mathrm{ft}$., $\$ 2$ each, \$18 for 10 .

\section{LARIX • Larch}

Larix laricina. American Larcb; Tamarack. (Lr) Rapid-growing pyramidal tree, becoming irregular at maturity, with very attractive light green foliage like that of a bright green deciduous spruce. When grown by itself and well developed it is a very ornamental tree. Although a native of swampy ground it thrives in ordinary soils. 6 to $8 \mathrm{ft}$., $\$ 2.75$ each.

L. leptolepis. Japanese Larcb. (Lr) A slender, pyramidal tree with foliage like an evergreen spruce, but which is dropped in autumn. A very beautiful, quick-growing tree which enjoys a moist soil. 5 to $6 \mathrm{ft}$., $\$ 2.25$ each; 4 to $5 \mathrm{ft}$., $\$ 2$ each; 3 to $4 \mathrm{ft}$., $\$ 1.50$ each.

\section{LIQUIDAMBAR}

Liquidambar styraciflua. Sweet Gum. (Mm) A handsome native tree of stately growth, with corky bark and leaves that resemble those of the maple, but are more star-shaped, and glossy green, turning deep purplish crimson in autumn. It thrives best south of Boston. 8 to $10 \mathrm{ft}$., $\$ 6.50$ each; 6 to $8 \mathrm{ft}$., $\$ 4.50$ each. 


\section{LIRIODENDRON}

Liriodendron tulipifera. Tulip Tree. (Lr) This large, symmetrical tree has smooth bark, glossy, light green, fiddle-shaped leaves and spreading branches. The flowers are tulip-like, greenish yellow blotched with orange. 6 to $8 \mathrm{ft}$., $\$ 2.50$ each; 5 to $6 \mathrm{ft} ., \$ 2$ each.

\section{MAGNOLIA}

Magnolia soulangeana. Saucer Magnolia. A sturdy, picturesque tree of moderate size, covered in spring with giant pinkish flowers before the leaves appear. Very handsome and easily one of the most ornamental flowering trees in existence. 3 to $4 \mathrm{ft}$., $\$ 12$ each; 2 to $3 \mathrm{ft} ., \$ 9$ each.

\section{MALUS - Flowering Crabapple}

The Wild Crabs are smallish, round-headed trees, literally covered with blossoms in the spring. Most varieties are very fragrant, and aII are followed in the faIl by a profusion of waxy fruits varying from pale green to orange-red. Very beautiful for a corner of the Iawn or as the background to Iower shrubs, and they do especially well in low spots or Iittle hollows. The famous Cherries of Japan fall far below the Wild Crabs in beauty and color, and will never be missed by those gardeners who are wise enough to use Wild Crabs instead.

Malus arnoldiana. Arnold Crab. (Sm) Semi-double pink blossoms in early spring, followed by yellow fruit, and attractive foliage make this a very popular variety. 5 to $6 \mathrm{ft}$., $\$ 5$ each; 4 to

$5 \mathrm{ft}$., \$3 each, \$27 for 10 .

M. atrosanguinea. Carmine Crab. (Sm) Like most Flowering Crabapples, it makes an excellent specimen or lawn tree for in spring it is a mass of single crimson blooms of such richness of color that it is easily the darkest and brightest of the rose-tinted Crabs. The color does not fade to white. It makes a vigorous, round-headed shrub or small tree with attractive foliage and ornamental, drooping clusters of fruits. 5 to $6 \mathrm{ft}$., $\$ 3.50$ each; 4 to $5 \mathrm{ft}$., $\$ 2.50$ each; 3 to $4 \mathrm{ft}$., $\$ 2$ each.

M. foribunda. Japanese Flowering Crab. (Sm) One of the best early, springflowering, bushes or small trees. The deep pink or rosy red flowers appearing with the leaves, are produced in great abundance, followed by very showy reddish, pea-sized fruit on long, slender stems, making it very ornamental in autumn. 5 to $6 \mathrm{ft}$., $\$ 4$ each; 4 to $5 \mathrm{ft}$., $\$ 3$ each; 3 to $4 \mathrm{ft}$., $\$ 2$ each.

M.halliana parkmani. Parkman's Crab. (Sm) Irregular and awkward when young, but a most attractive tree when filled with buds and blossoms. Each bud regularly produces five blossoms on stems 3 inches long, so slender that they bend with the buds or bloom in a very graceful fashion. The buds are carmine and open to semi-double blossoms. When in bloom, the tree presents a most gorgeous appearance. 4 to $5 \mathrm{ft}$., $\$ 3.50$ each; 3 to $4 \mathrm{ft}$., $\$ 2$ each.

\section{MALUS, continued}

M. ioensis plena. Becbtel's Crab. (Sm) One of the most beautifuI Flowering Crabs, producing double, fragrant flowers of delicate pink resembling small roses. 5 to $6 \mathrm{ft}$., $\$ 3.50$ each; 4 to $5 \mathrm{ft}$., $\$ 2.50$ each, $\$ 22.50$ for $10 ; 3$ to $4 \mathrm{ft}$., $\$ 2$ each, $\$ 18$ for 10 .

M. niedzwetzkyana. Redvein Crab. (Mm) A very ornamental tree with deep pink flowers. A larger grower than most Flowering Crabs. 5 to $6 \mathrm{ft}$., $\$ 3$ each, $\$ 27$ for $10 ; 4$ to $5 \mathrm{ft}$., $\$ 2.50$ each, $\$ 22.50$ for 10 . M. prunifolia rinki. Chinese Apple. Showy white flowers followed by red, yellow, and green fruits $11 / 2$ inches in diameter. Cultivated by the Chinese as a fruit tree but an extremely decorative ornamental as well. 3 to $4 \mathrm{ft}$., $\$ 2.50$ each; 2 to $3 \mathrm{ft}$., \$2 each.

M. sargenti. Sargent Crab. A dwarf tree, with white blooms and showy red fruit. 4 to $5 \mathrm{ft}$., $\$ 3.50$ each; 3 to $4 \mathrm{ft}$., $\$ 2.75$ each; 2 to $3 \mathrm{ft}$., $\$ 2$ each, $\$ 18$ for 10 .

M. scheideckeri. Scbeidecker Crab. A very showy, early-flowering variety with double pink blooms. 5 to $6 \mathrm{ft}$., $\$ 3$ each; 4 to $5 \mathrm{ft}$., $\$ 2.50$ each, $\$ 24$ for 10 ; 3 to $4 \mathrm{ft}$., $\$ 2$ each, $\$ 18$ for 10 .

M. spectabilis. Cbinese Flowering Crab. (Sm) This small tree has very attractive flowers-the opening buds are almost coral-red and very showy. 5 to $6 \mathrm{ft}$., $\$ 3$ each; 4 to $5 \mathrm{ft}$., $\$ 2.50$ each; 3 to $4 \mathrm{ft}$., \$2 each.

M. theifera. Tea Crab. Have you a Tea Crab? Probably not, but by all means take our advice and plant at least one this year. You will like the character of the tree, its irregular branches, and its profusion of pink flowers. 3 to $4 \mathrm{ft}$., $\$ 3.50$ each, $\$ 33$ for $10 ; 2$ to $3 \mathrm{ft}$., \$2 each, \$18 for 10 .

All Flowering Crabs will be taken up, balled and burlapped, without extra charge.

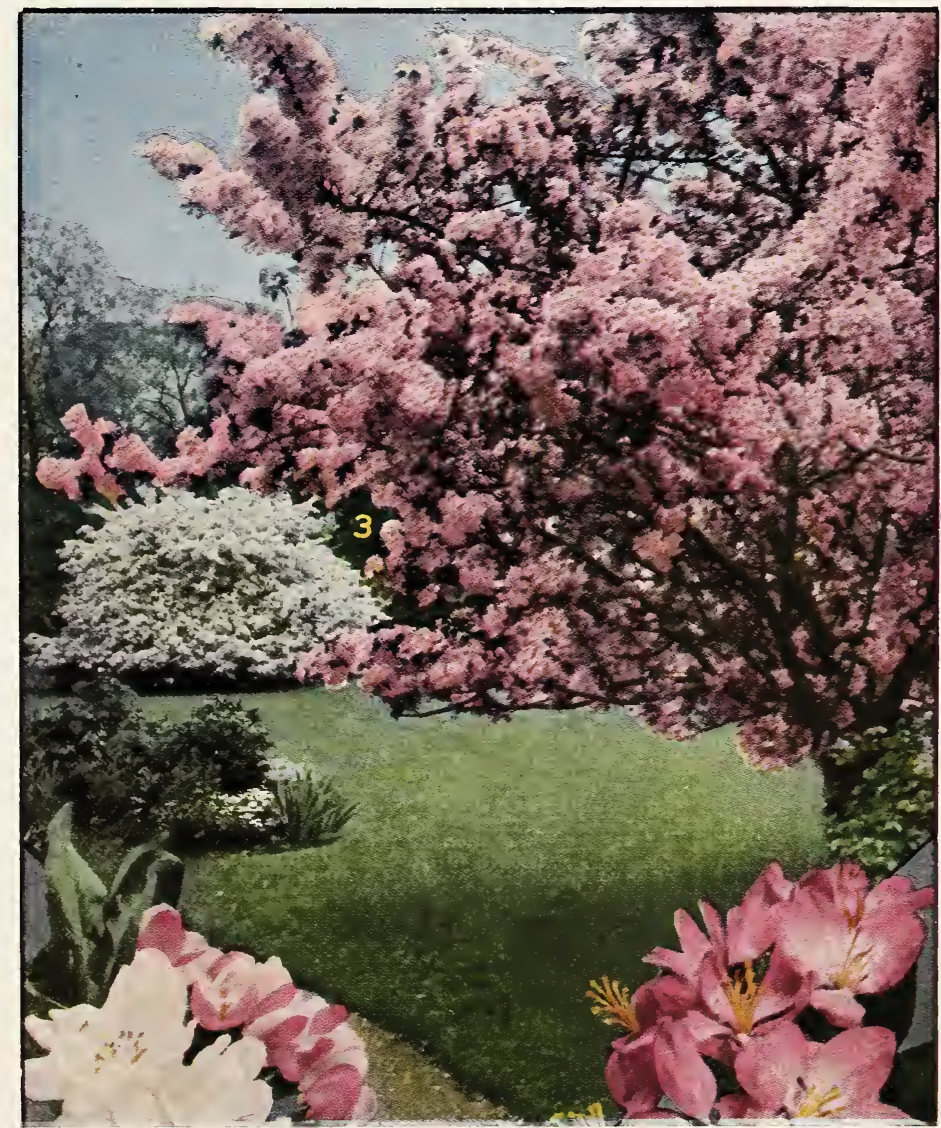

Malus. Flowering Crab. Showers of pink and white petals. 


\section{MORUS · Mulberry}

Morus alba tatarica. Russian Mulberri. (Mm) A low, very bushy-topped tree with reddish fruit which birds like; very hardy and desirable. 8 to $10 \mathrm{ft}$., \$2.25 each, S21 for $10 ; 6$ to $8 \mathrm{ft}$., \$1.75 each, \$16 for 10

M. alba pendula. Teas Weeping Mulberr. (Dv) One of the best small weeping lawn trees, forming a perfect umbrella-shaped head of light green, deeply lobed foliage. Fruit reddish purple. Thrifty and hardy. 2-yr. heads, 5 to $6 \mathrm{ft}$., $\$ 3.50$ each, $\$ 33$ for 10.

\section{NYSSA - Tupelo}

Nyssa sylvatica. Sour Gum; Tupelo. A slender, roundtopped tree with glossy, oval leaves which turn blazing scarlet in autumn. Very graceful and attractive at all seasons. 2 to $3 \mathrm{ft}$., \$2 each; 18 to $24 \mathrm{in}$., \$1.50 each, $\$ 12.50$ for 10 .

\section{OXYDENDRUM • Sorrel Tree}

Oxydendrum arboreum. Sourwood. (Sm) Slender and graceful as a birch, this tree will fill a narrow corner of fit in with the shrubs. The flowers are its crowning glory, coming in long, curving racemes, like drooping bouquets of lily-of-the-valley, in midsummer when no other tree is in bloom. It is the first tree in autumn from which to pick a spray of scarlet foliage. 18 to 24 in., \$2 each.

\section{PHELLODENDRON - Cork Tree}

Phellodendron amurense. Amur Cork Tree. (Mr) An excellent street tree as it resists drought and is not attacked by insects. It grows rapidly when young, thriving in almost any kind of soil, and has a round, broad head, and gray bark. The leaves turn yellow in autumn. 12 to $14 \mathrm{ft}$., $\$ 4$ each, $\$ 36$ for 10 ; 10 to $12 \mathrm{ft}$., $\$ 3$ each, $\$ 25$ for 10 .

\section{PLATANUS • Plane Tree}

The Planes are massive, ornamental trees especially adapted to street planting and parks. They have ornamental bark, big handsome leaves, and in a general way resemble the maples. Because of their resistance to smoke and gases they are especially valuable for city planting.

Platanus occidentalis. American Plane Tree. (Lr) One of the most massive and perhaps the tallest deciduous tree in North America. The leaves are heart-shaped at the base, with short, sharp-pointed lobes, and densely cover the branches which are mottled white where the thin bark scales off. An excellent street and park tree. This is the common very handsome American Sycamore. 10 to $12 \mathrm{ft}$., \$3 each; 8 to $10 \mathrm{ft}$., $\$ 2.25$ each; 6 to $8 \mathrm{ft}$., $\$ 2$ each.

P. orientalis. European Plane Tree. (Lr) Another excellent street and park tree, with broad, round head on a comparatively short trunk, and dullish gray or greenish white bark. A rapid grower which has become very popular for street planting in the larger cities. 10 to $12 \mathrm{ft}$., $\$ 3.25$ each; 8 to $10 \mathrm{ft}$., $\$ 2.50$ each, $\$ 22.50$ for $10 ; 6$ to $8 \mathrm{ft}$., $\$ 1.75$ each.

\section{POPULUS • Poplar}

Quick-growing trees, never very Iarge, but always of agreeable form. They are voracious feeders and should not be planted where their roots aı likely to get into drains. Poplars should never be planted singly, as it requires a group of them to secure the picturesque effect for which they are noted. This applies particularly to the thin, columnar types like the Lombardy.

†Populus balsamifera. Balsam Poplar. (Lr) A tall, upright, symmetrical tree of rapid, luxuriant growth, with large, glossv leaves which are retained late in autumn. The buds exhale an agreeable odor and are used for medicinal purposes. This tree will thrive under severe exposures. 12 to $14 \mathrm{ft}$., \$2 each, \$1 8 for $10 ; 10$ to $12 \mathrm{ft}, \$ 1.75$ each, \$16 for 10

\section{POPULUS, continued}

P. nigra italica. Lombardy Poplar. (Lr) This wellknown, upright, and extremely rapid-growing tree has bright pale green leaves, lighter beneath, and branches down to the ground. It is used very satisfactorily for screen purposes and also for formal effects on account of its columnar form. 12 to $14 \mathrm{ft}$., $\$ 2.50$ each, $\$ 22$ for $10 ; 10$ to $12 \mathrm{ft}$., $\$ 2$ each, $\$ 18$ for $10 ; 8$ to $10 \mathrm{ft}$., $\$ 1.50$ each $\$ 12.50$ for 10 ; 6 to $8 \mathrm{ft}$., \$1.25 each, \$11 for 10 .

\section{PRUNUS • Plum}

Charming small trees with dark-colored foliage, suitable for specimens or groups on the lawn and among shrubbery, where they are particularly effective.

Prunus cerasifera, Othello. (Improved Pissard.) A handsome, small tree with deeper color than the original Purple-leaved Plum, of which it is an improved variety. 8 to $10 \mathrm{ft}$., $\$ 3.75 \mathrm{each} ; 6$ to $8 \mathrm{ft}$., $\$ 3.25$ each; 5 to $6 \mathrm{ft}$., \$2.75 each.

P. cerasifera pissardi. Purpleleaf Plum. Very popular decorative tree, with handsome, dark purple leaves and pretty wine-red fruits. It retains its rich color until au tumn. 6 to $8 \mathrm{ft}$., $\$ 3$ each; 4 to $5 \mathrm{ft}$., $\$ 2$ each.

\section{PRUNUS}

\section{Japanese Flowering Cherries}

A choice selection of the famous Cherry trees of Japan, celebrated in this country because of the wonderful collection in Potomac Park, at Washington, D. C., which attracts thousands of visitors every spring. They bloom very early and are most showy. The first variety is not a true Japanese sort but is equally beautiful.

Prunus avium albo-plena. A handsome, decorative tree with charming, double, white flowers. 5 to $6 \mathrm{ft}$., $\$ 4$ each; 4 to $5 \mathrm{ft}$., \$3 each.

P. subhirtella rosea pendula. Weeping Japanese Cherry. An extremely decorative form, grown on a tall, straight stem, from the top of which the slender branches sweep in a broad umbrella-like head. The flowers are various shades of bright pink. Extremely handsome for specimen use. 5 to $6 \mathrm{ft}$., $\$ 5$ each.

P., Kansan or Setizan. Bright pink, true Japanese variety. 4 to $5 \mathrm{ft}$., $\$ 4$ each; 3 to $4 \mathrm{ft}$., $\$ 3$ each.

P., Kofugen. Buds crimson; blossoms old-rose. 4 to $5 \mathrm{ft}$., $\$ 4$ each.

P., Naden. Lovely, double pink. 4 to $5 \mathrm{ft}$., $\$ 4$ each; 3 to $4 \mathrm{ft}$., $\$ 3$ each.

P., Shirofugen. Buds pink; blossoms light pink. 4 to $5 \mathrm{ft}$., \$4 each; 3 to $4 \mathrm{ft}$., \$3 each.

\section{PTELEA - Hop Tree}

†Ptelea trifoliata. Common Hop Tree. (Ds) A round-headed, loosely branched tree with glossy green foliage which, if bruised, exhales a pleasant hop-like odor. It is covered in the fall with numerous green fruit-pods. 6 to $8 \mathrm{ft}$., $\$ 1.25$ each, $\$ 11$ for $10 ; 5$ to $6 \mathrm{ft}$., $\$ 1$ each, $\$ 9$ for 10 .

\section{QUERCUS • Oak}

Splendid trees, rather slow-growing at first, but when once established develop amazingly within a few years. They are of noble proportions and give an impression of boundless strength and vigor.

Quercus bicolor. Swamp Wbite Oak. (Lr) Thrives in wet locations, but does equally well in welldrained soils. It has a round-topped, open head and is one of the fastest growing Oaks. 10 to $12 \mathrm{ft}$., $\$ 5$ each, $\$ 48$ for $10 ; 8$ to $10 \mathrm{ft}$., $\$ 4$ each.

Q. coccinea. Scarlet Oak. A large, handsome tree especially valued for brilliant scarlet foliage in autumn. 6 to $8 \mathrm{ft}$., $\$ 4.50$ each; 5 to $6 \mathrm{ft}$., $\$ 3.50$ each. 


\section{QUERCUS, continued}

Q. palustris. Pin Oak. (Lr) This very handsome tree is particularly adapted to lawn and avenue planting. It has drooping branches and finely divided dark green leaves which turn red in fall. A rapid grower that prefers moist soil, and, as it is fibrous-rooted, transplants weII. 10 to $12 \mathrm{ft}$., $\$ 10$ each; 6 to $8 \mathrm{ft}$., $\$ 4$ each.

†Q. rubra. Common Red Oak. (Lr) A broad tree of rapid growth with large, rich green foliage that turns bronzy red in the fall. Will flourish in poor soil. 6 to $8 \mathrm{ft}$., $\$ 3.50$ each.

\section{ROBINIA · Locust}

†Robinia pseudoacacia. Common Locust. (Lr) An excellent variety for producing natural, informal effects as it grows very rapidly to 80 feet high. In early summer it bears a profusion of fragrant white flowers in drooping racemes. Will thrive under city conditions, and withstand severe exposure. 6 to $8 \mathrm{ft}$., $\$ 2.50$ each; 5 to $6 \mathrm{ft}$., $\$ 1.75$ each, $\$ 15$ for $10 ; 4$ to $5 \mathrm{ft}$., $\$ 1.50$ each, $\$ 14$ for 10 .

\section{SALIX • Willow}

Wherever there is a stream, a pond, or a bit of low ground, the Willows should be considered. They are among the most beautifuI and graceful of trees, and are extremely attractive in early spring when the tiny pale green leaves first open.

Salix babylonica. Babylon Weeping Willow. (Lr) Probably the best known Willow and splendid sort for formal effects. It has very drooping, long, slender branches of olive-green. Will grow in any good soil. 8 to $10 \mathrm{ft}$., $\$ 2$ each; 6 to $8 \mathrm{ft}$., $\$ 1.50$ each, $\$ 14$ for 10 .

†S. pentandra. Laurel Willow. (Mv) An ornamentaI tree of upright, dense growth, making it fine for screens. The bark is brownish green, and the leaves dark glossy green, much like the California privet. Excellent for seashore planting. 6 to $8 \mathrm{ft}$., $\$ 1$ each, $\$ 9$ for $10 ; 5$ to $6 \mathrm{ft}$., $90 \mathrm{cts}$. each, $\$ 8$ for $10 ; 4$ to $5 \mathrm{ft}$., slender, 75 cts. each, $\$ 7$ for $10 ; 3$ to $4 \mathrm{ft}$., bushy, 70 cts. each, $\$ 6.50$ for 10 .

†S. vitellina. Golden Willow. ( $\mathrm{Lm})$ A Iarge and venerable-looking tree, conspicuous at all seasons, but particularly i n winter on account of its yellow bark. 6 to $8 \mathrm{ft}$., $\$ 1.25 \mathrm{each}, \$ 11$ for $10 ; 5$ to $6 \mathrm{ft}$., $\$ 1$ each, $\$ 9$ for 10 .

\section{SORBUS • Mountain-Ash}

Sorbus aucuparia. European Mountain-Ash. (Mm) The clusters of scarlet berries, borne in abundance from July to winter, make this a very attractive small lawn tree. Visitors to the Nursery in autumn always ask the name of this tree with the bunches of scarlet berries. 10 to $12 \mathrm{ft}$., $\$ 3$ each; 8 to $10 \mathrm{ft}$., $\$ 2.50$ each, $\$ 22.50$ for $10 ; 6$ to $8 \mathrm{ft}$., $\$ 2$ each, $\$ 18$ for 10 .

\section{SYRINGA • Lilac}

Syringa japonica. Japan Tree Lilac. (Sm) A remarkable Tree Lilac from Japan with creamy white flowers. Should be on every lawn. 4 to $5 \mathrm{ft}$., $\$ 2 \mathrm{each}$, $\$ 18$ for 10

\section{TAXODIUM - Bald Cypress}

Taxodium distichum. Bald Cypress. (Lr) A stately tree with foliage like an evergreen but which is shed in autumn. 4 to $5 \mathrm{ft}$., $\$ 3$ each; 3 to $4 \mathrm{ft}$., $\$ 2$ each, $\$ 18$ for 10 .

We do not attempt to list all the sizes of trees that we may have to offer, but frequently we can furnish some of these varieties in larger as well as smaller sizes. If you will write us about the size for which you are looking we will be very pleased indeed to quote you prices.

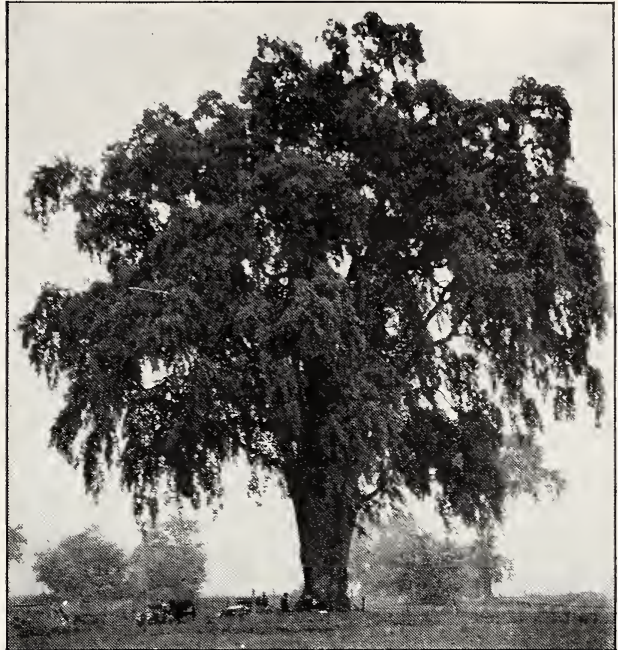

Ulmus americana. American Elm, stately and magnificent and the pride of old New England towns

TILIA · Linden

Big, handsome trees of rapid growth and among the best ornamentals for either lawn or street planting. They are beautiful in foliage, in flower, and when bare, and should be widely used.

Tilia americana. American Linden. (Lr) An American species, with intensely fragrant yellow flowers and broad, round top which gives plenty of shade. Suitable for lawns, parks, and streets. 10 to $12 \mathrm{ft}$., $\$ 4.50$ each; 8 to $10 \mathrm{ft}$., $\$ 3.50$ each.

T. spectabilis. Showy Linden. This vigorous, Ioftygrowing tree has blooms like $T$. americana and grayish downy leaves. A handsome, densely headed, ornamental tree useful for a great many purposes. 10 to $12 \mathrm{ft}$., $\$ 7.50$ each; 8 to $10 \mathrm{ft}$., $\$ 6$ each.

\section{ULMUS · Elm}

The EIms are famous trees and have a rural, pastoraI air that fits admirably into Iandscape planting schemes. They almost always look best in a wide-spaced row, or isolated in a freld or on a hillside, and some of the finest of our New England villages owe their beauty to their EIm-bordered streets. There is scarcely any purpose for which they are not almost always first choice, because of their grace, their permanence, and their rapid growth.

Ulmus americana. American Elm. (Lr) The most beautiful of the EIms, and the glory of our old New England towns. It is Iofty and spreading, with drooping branches and is very hardy. A fine avenue tree. 12 to $14 \mathrm{ft}$., $\$ 5$ each, $\$ 48$ for $10 ; 10$ to $12 \mathrm{ft}$. $\$ 4$ each, $\$ 36$ for $10 ; 8$ to $10 \mathrm{ft}$., $\$ 2.75$ each, $\$ 25$ for 10 ; 6 to $8 \mathrm{ft}$., $\$ 2$ each, $\$ 18$ for 10 .

U. americana, Vase-shaped. Selected specimens of uniform shape and habit. Especially fine where special uniform effects are desired. 12 to $14 \mathrm{ft}$., $\$ 6$ each; 10 to $12 \mathrm{ft}$., $\$ 5$ each, $\$ 48$ for 10 .

U. pumila. Siberian Elm. A new tree from China which was first thought to be of dwarf, bushy habit hence the name pumila, but discovered to be a handsome, large tree comparable to the American Elm in size and beauty, but surpassing it in its extremely rapid growth. Seedlings grow to tall fine specimens within a few years, and enthusiasts predict that its hardiness, its rapidity of growth, and the beauty of the mature tree will give it unprecedented popularity. It is just the thing for planting on a new place for within the time it takes an ordinary tree to establish itself, the Chinese EIm will grow into a large mature tree. 6 to $8 \mathrm{ft}$., $\$ 2.50$ each; 5 to $6 \mathrm{ft}$., $\$ 2$ each. 


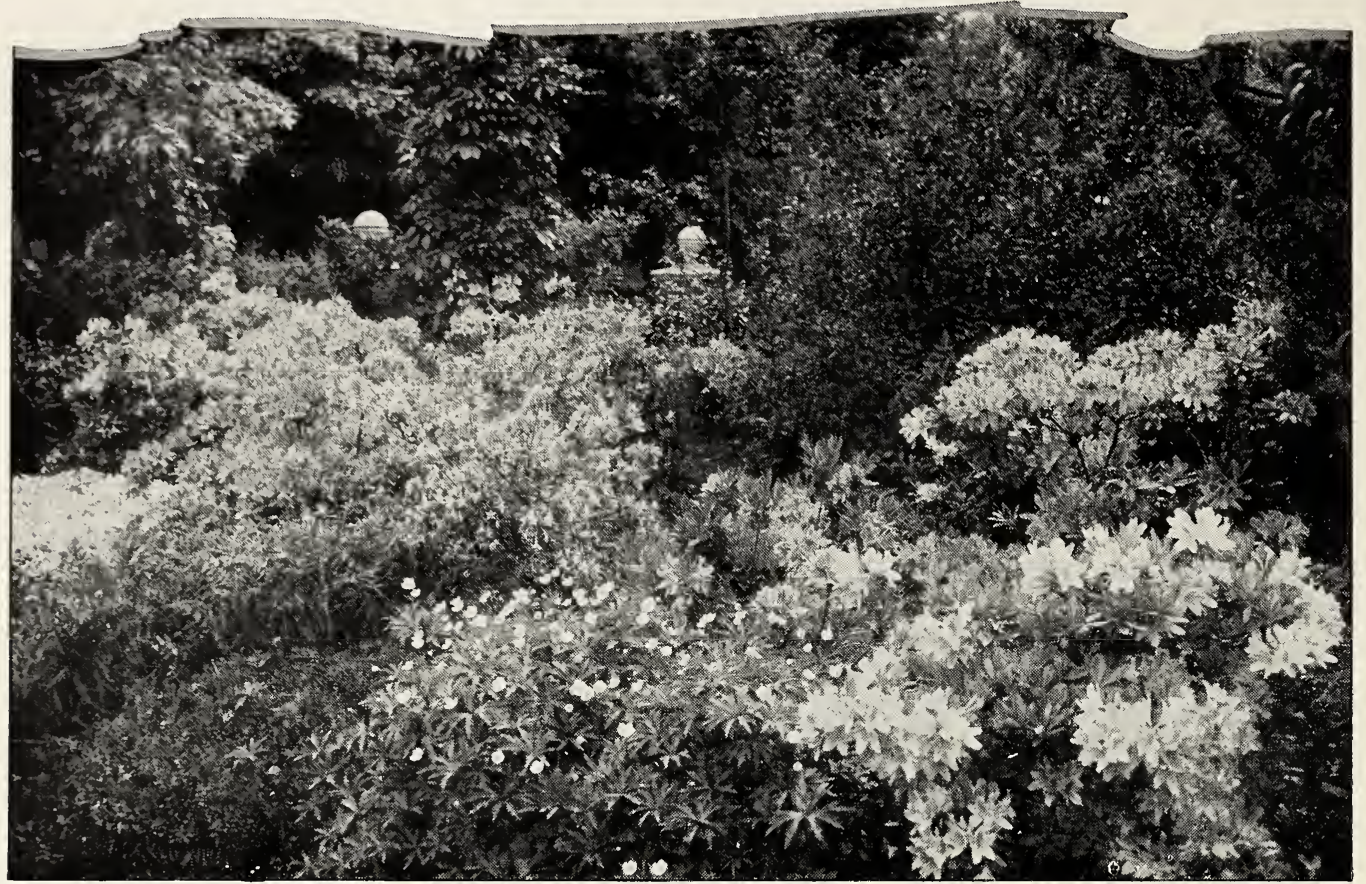

Azalea mollis. Gayest and most reckless in profusion of bloom are the Azaleas, and Mollis is particularly fine

\section{DECIDUOUS SHRUBS}

THERE is a tremendous number of beautiful bushes or shrubs which embrace flowering forms of every conceivable variety, and others admired for their fruits, or for their leaves, or for their interesting shape.

They should always be planted in groups or borders; isolated specimens, unless very large, look lonesome and forlorn. A good arrangement invariably provides open stretches of lawn bordered with irregular masses of shrubs against the boundary-line or buildings. It is best not to mix too many kinds in any one group. Their outline and habits differ so very much that best effects always come from planting large restful colonies of one kind or closely related sorts.

The ground for shrubs should be weII prepared and worked all over, and be kept cultivated and free from weeds until the shrubs have grown to cover the whole space. They cannot be expected to thrive and do their duty if they are stuck in a little hole in the sod.

\section{ABBREVIATIONS}

Denoting Size: L, large; M, medium; S, small; D, dwarf; VD, very dwarf.

Denoting Varieties Suitable for Seashore Planting: $(\dagger)$.

Denoting Varieties Producing Fruit Which Attracts Birds: ( $\S)$.

\section{ACANTHOPANAX}

Acanthopanax pentaphyllum. Fiveleaf Aralia. (M) A graceful shrub, with arching, spiny branches and bright green, shining foliage. Excellent in shady places, on rocky banks and slopes, and also for hedges. 4 to $5 \mathrm{ft}$., $\$ 1$ each, $\$ 8$ for $10 ; 3$ to $4 \mathrm{ft}$., 75 c. each, $\$ 6$ for $10 ; 2$ to $3 \mathrm{ft}$., 60 c. each, $\$ 5$ for 10 .'

\section{AMELANCHIER}

Shadbush . Juneberry

\$Amelanchier canadensis. Downy Shadblow. (L) Small, graceful tree which breaks into a lacy cioud of snowy flowers in early spring; followed by small purplish fruit in autumn. 4 to $5 \mathrm{ft}$., $\$ 1.75 \mathrm{each}$; 3 to $4 \mathrm{ft}$., $\$ 1.25$ each, \$11 for 10 .

§. rotundifolia. European Shadblow. A stiff, upright shrub, covered with clustered white flowers in early spring and bluish black berries in autumn. 4 to $5 \mathrm{ft}$., $\$ 1$ each; 3 to $4 \mathrm{ft}$., 75 cts. each, $\$ 6$ for 10 .
Remember, 5 or more plants of one kind will be furnished at rate for 10 .

\section{AMORPHA}

Amorpha fruticosa. Indigobush. (L) The unusual, dark violet-purple flowers in June make this an exceptionally interesting shrub. It is of spreading habit, with fine, feathery foliage. Excellent for massing. 5 to $6 \mathrm{ft}$., $\$ 1$ each, $\$ 7.50$ for $10 ; 4$ to $5 \mathrm{ft}$., $75 \mathrm{cts}$. each, $\$ 6$ for $10 ; 3$ to $4 \mathrm{ft}$., 60 cts. each, $\$ 5$ for 10 .

\section{ARONIA - Chokeberry}

$\S †$ Aronia arbutifolia. Red Cbokeberry. (L) This attractive, densely branched shrub bears clusters of white flowers in May, followed by very ornamental red berries. 3 to $4 \mathrm{ft}$., $\$ 1.25$ each, $\$ 11$ for $10 ; 2$ to $3 \mathrm{ft}$., $90 \mathrm{cts}$. each, $\$ 8$ for 10 .

§A. melanocarpa. Black Chokeberry. (M) Similar to $A$. arbutifolia, but the fruit is glossy black. 3 to $4 \mathrm{ft}$., $\$ 1.25$ each, $\$ 10$ for 10 .

Bay State Nurseries employ no agents or salesm $3 n$ soliciting orders. 


\section{Hardy Azaleas}

All the Azaleas we grow are hardy and particularly attractive for American gardens and in shady spots about an estate. Like the Rhododendrons, they will not live in a soil containing lime. They bloom from the first of May until the middle of Julv, and an assortment of them will provide at least one variety in blossom all the time during that period. The Roman numerals refer to their order of blooming.

\section{All Azaleas will be balled and burlapped (B \&B) without extra charge}

Azalea arborescens. Sweet Azalea. (M) The very fragrant white flowers of this variety have pink stamens and appear after the dark green leaves are nearly fuII grown. (XI) 2 to $21 / 2 \mathrm{ft}$., $\$ 4.50$ each, $\$ 40$ for $10 ; 18$ to 24 in., $\$ 3.50$ each, $\$ 33$ for 10.

A. calendulacea. Flame Azalea. (M) The most showy Azalea, and one of the most beautiful flowering shrubs. It remains in bloom several weeks, bearing a profusion of scentless, orange-yellow or flame-red flowers before the leaves appear. (X) $21 / 2$ to $3 \mathrm{ft}$., $\$ 4.50$ each, $\$ 42$ for $10 ; 2$ to $21 / 2 \mathrm{ft}$., $\$ 3.50$ each, $\$ 33$ for 10 .

A. canescens. Piedmont Azalea. (M) This variety has rosy pink flowers which open before or with the unfolding of the leaves, and in early spring fill the woods with beauty and fragrance. An important and useful variety. (VII) 2 to $3 \mathrm{ft}$., $\$ 3.50$ each, $\$ 33$ for $10 ; 18$ to 24 in., $\$ 2.75$ each, $\$ 25$ for 10 .

A. kaempferi. Torcb Azalea. (M) A very handsome, tall-growing variety with flowers which vary from bright orange-red to salmon-pink. It thrives in partial shade and is extremely floriferous and hardy in New England. Exceptionally desirable and we believe it is one of the best of all for brilliancy and refinement of color, combined with other good shrub virtues. One can make no mistake in planting this Azalea liberally. (IV) 15 to 18 in., \$4 each, \$36 for $10 ; 12$ to 15 in., \$3 each, \$27 for 10 .

A. kaempferi Hybrids. A new race of hybrid varieties raised from the splendid Kaempferi, with large, showy flowers of various shades of rich salmon and orange. These are new. (V) 18 to 24 in., bushy, \$10 each, \$95 for $10 ; 15$ to 18 in., bushy, \$7.50 each, $\$ 72$ for 10 .

A. mollis. Cbinese Azalea. (S) Resembles a dwarf rhododendron with good foliage and bears flowers in all shades of red, yellow, and orange. It is perfectly hardy, thriving in sunny positions anywhere, and is excellent in masses. Its roots must not come in contact with barnyard manure. All that we said of the value of Azalea kaempferi applies with equal force to this variety. Both are superb Azaleas. Excellent plants of mixed colors. (VIII) 18 to 24 in., $\$ 4.50$ each, $\$ 42$ for $10 ; 15$ to 18 in., $\$ 3.50$ each, $\$ 33$ for 10 .

A. mollis, Louisa Hunnewell. A new hybrid of Azalea mollis which is perfectly hardy in New England. Flowers brilliant salmon-red or orange, and borne in tremendous quantity. (IX) 15 to 18 in., $\$ 4.50$ each; 12 to 15 in., $\$ 3$ each, $\$ 27$ for 10 .

A. mucronulatum. Mongolian Azalea. An upright shrub, 6 feet high or more, valued for its very early bright rose flowers and the handsome autumn color of its leaves. (I) 15 to 18 in., $\$ 4$ each, $\$ 36$ for 10.

A. nudiflora. Pinxterbloom. (S) The flowers vary from deep pink to reddish purple, and appear in May. Suitable for mass planting and flourishes in light sandy soil. (VI) 18 to 24 in., \$3 each; 15 to 18 in., $\$ 2.50$ each, $\$ 22.50$ for 10 .

A. poukhanensis. Korean Azalea. A Iow-growing Azalea producing a profusion of pale lilac-purple flowers, utterly different from all other Azaleas. Hardy at Boston. (III) 18 to 24 in., $\$ 5$ each, $\$ 45$ for 10 .

A. vaseyi. Pinksbell Azalea. (M) A tall shrub of open, irregular habit, with slender stems and smalI, compact clusters of pink flowers appearing before the leaves. Foliage turns deep crimson in the fall. (II) 18 to 24 in., $\$ 4.50$ each, $\$ 42$ for $10 ; 15$ to 18 in., $\$ 3.50$ each, \$33 for 10 .

A. viscosa. Swamp Azalea; Wild Honeysuckle. Vigorous shrub with an abundance of pink and white, deliciously fragrant flowers. It likes damp places, but will thrive in the shrub border if given plenty of water, and kept absolutely free from lime. $2 \frac{1}{2}$ to $3 \mathrm{ft}$., $\$ 3.50$ each, $\$ 33$ for $10 ; 2$ to $21 / 2 \mathrm{ft}$., $\$ 2.75$ each, $\$ 25$ for 10 .

\section{BERBERIS • Barberry}

These attractive shrubs are of inestimable value for their neat, compact growth, beautiful foliage and fruit, and their adaptability to a multitude of uses. They are among the finest hedge plants, and several of them make beautiful specimens interspersed through a mixed shrubbery. The colored foliage forms are particularly effective for variety and special emphasis. Note that two splendid Evergreen varieties of Barberries are listed among the Evergreen Shrubs.

Berberis aggregata pratti. Pratt's Barberry. An erect, bushy shrub with spiny branches and narrow leaves. Flowers bright yellow, followed by salmonred berries in clusters 6 inches long. Very handsome and showy in autumn and winter. 2 to $3 \mathrm{ft}$., $\$ 1.50$ each, $\$ 13.50$ for 10 .

§†B. sieboldi. Siebold Barberry. (S) A very handsome shrub with leaves purplish when unfolding, becoming deep red in the autumn. Its Iarge, bright red berries retain their color until spring, making a brave display all winter. 3 to $4 \mathrm{ft}$., $75 \mathrm{cts}$. each, $\$ 6.50$ for 10 .

$\S \dagger$ B. thunbergi. Japanese Barberry. (M) We know of no better hedge plant and slow-growing shrub for New England and other northern states than the Japanese Barberry. The plant is not only hardy but also graceful and attractive. Its foliage is of a rich green color in the summer, and in the autumn is very brightly colored. The fruit is equally showy and remains on the plants from the last of the summer until midwinter. Like other hedge plants, the Barberry should be planted at the rate of one plant to one foot of ground-in other words, a space of 75 feet will require 75 plants. Our plants are well grown and very bushy, and our prices are reasonable for stock of this

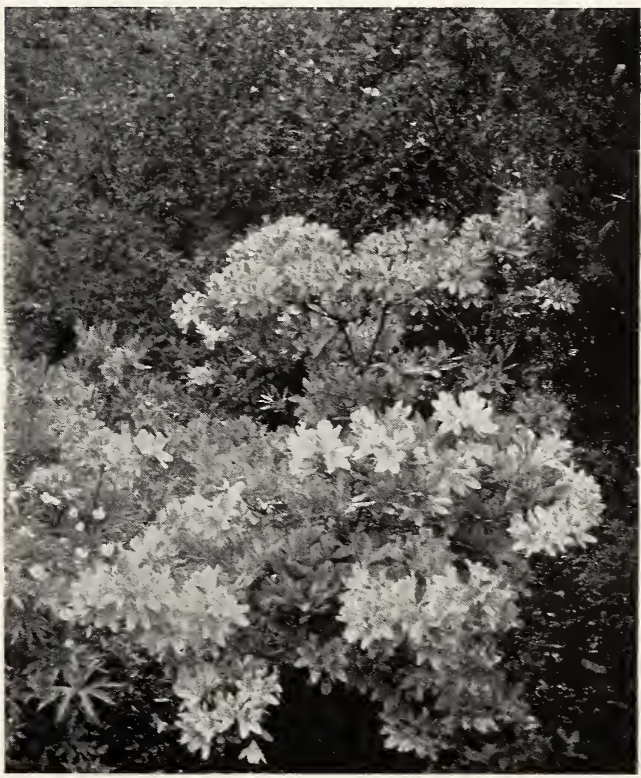

Azalea mollis in the shrub border 


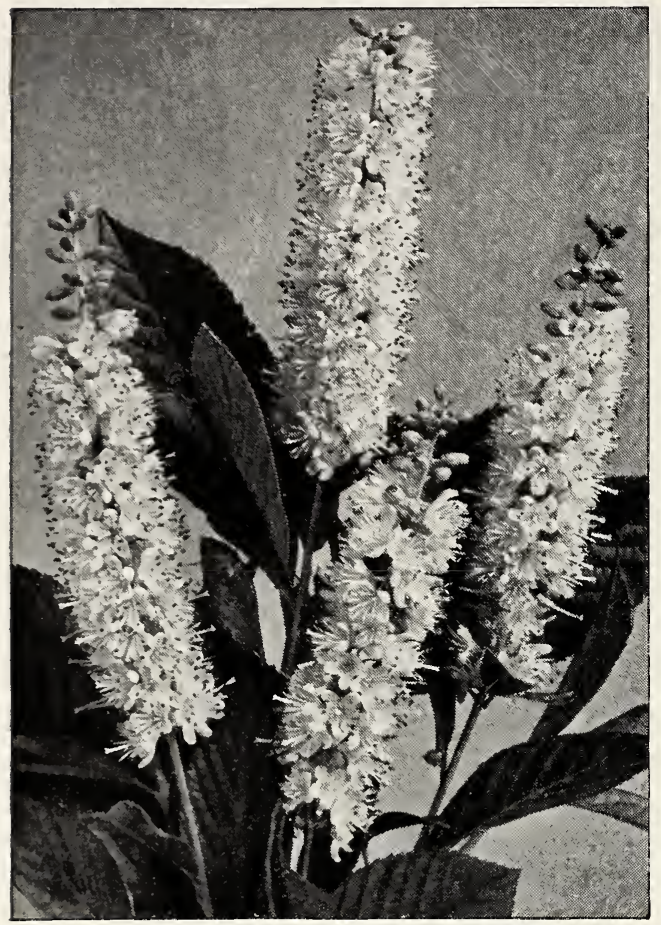

Clethra alnifolia. The Sweet Pepper Bush

Berberis Thunbergi, continued

quality. Remember that we allow the 100 rate on 25 or more plants of one kind.

3 to $31 / 2 \mathrm{ft}$., 90 cts. each, $\$ 7.50$ for $10, \$ 60$ per 100 ; $21 / 2$ to $3 \mathrm{ft}$., 60 cts. each, $\$ 5.40$ for $10, \$ 45$ per 100 ; 2 to $21 / \mathrm{ft}$., $50 \mathrm{cts}$. each, $\$ 4$ for $10, \$ 27$ per 100 18 to 24 in., 35 cts. each, $\$ 2.50$ for $10, \$ 18$ per 100 ; 15 to 18 in., 25 cts. each, $\$ 2$ for $10, \$ 12$ per 100 ; 12 to 15 in., 20 cts. each, $\$ 1.50$ for 10 , $\$ 9$ per 100 .

The above are all bushy, but we offer $21 / 2$ to $3-\mathrm{ft}$. specimens (B\&B), \$1 each, \$9 for 10 .

$\S+B$. thunbergi atropurpurea. Red-leaved Japanese Barberry. Exactly like the Japanese Barberry, except the foliage is a bright red and maintains this color throughout the season. This makes a splendid plant for a situation where something bright and cheery is desired, and one that needs no coddling or special care, beyond ordinary soil and unobstructed sunshine. 2 to $21 / \mathrm{ft}$., $\$ 1.25$ each, $\$ 10$ for $10 ; 18$ to 24 in., $\$ 1$ each, $\$ 9$ for 10 ; 15 to 18 in., 90 cts. each, $\$ 8$ for 10 .

Note.-Berberis tbunbergi and B. tbunbergi atropur purea have been approved by the U. S. Department of Agriculture and may be shipped anywhere without spreading wheat-rust.

\&+B. vernz. Verna Barberry. A desirable variety with pinkish red fruit. 2 to $21 / 2 \mathrm{ft}$., $\$ 1$ each, $\$ 9$ for 10 ; 18 to 24 in., 90 cts. each, $\$ 7.50$ for 10 .

$\S+$ B. vulgaris. European Barberry. (M) A handsome variety in the spring, with its golden yellow flowers and light green foliage, and in fall the bright scarlet berries make it very attractive. The branches are upright, arching and thorny. 2 to $3 \mathrm{ft} ., 60$ cts. each, $\$ 4.50$ for 10

$8+B$. vulgaris atropurpurea. Purple Barberry. (M) Similar to $B$. vulgaris, with beautiful violet-purple foliage and fruit. Very effective in groups and masses. 2 to $3 \mathrm{ft}$., 75 cts. each, $\$ 6.50$ for 10 .

If you wish shrubs in larger sizes than you find listed here, write us for quotations. We have larger specimens in nearly every variety mentioned here.

\section{BUDDLEIA - Butterfly Bush}

The Buddleias have flowers of the most attractive soft lavender-purple and make big, showy shrubs in a mixed planting.

Buddleia davidi magnifica. Oxeye Butterfly Bush. (M) An attractive shrub which produces an abundance of fragrant, showy, rosy purple flowers with orange-yellow centers, from August to October. The stalks die to the ground in the winter and grow anew to full stature each summer, if they do not winter-kill altogether, which seldom happens. 2-yr. plants, 60 cts. each, $\$ 5$ for 10 .

B. davidi veitchiana. Veitcb's Butterfly Busb. A more robust shrub than the foregoing, with mauve and orange flowers, borne in larger clusters, but similar in other respects. 2-yr. plants, $60 \mathrm{cts}$. each, $\$ 5$ for 10 .

\section{CAL YCANTHUS}

Calycanthus floridus. Common Sweet Sbrub. A favorite shrub found in old-fashioned gardens everywhere; will thrive in partial shade. It has fine, glossy foliage and pineapple-scented, chocolatecolored flowers that Iast far into the summer. 2 to $21 / 2 \mathrm{ft}$., $75 \mathrm{cts}$. each, $\$ 6.50$ for $10 ; 18$ to $24 \mathrm{in}$., $60 \mathrm{cts}$. each, $\$ 5$ for 10 .

\section{CARAGANA}

Caragana arborescens. Siberian Pea-Tree. (L) This very hardy tall shrub has dark green wood, neat foliage, and small yellow flowers in June. It flourishes in light, sandy soil. 3 to $4 \mathrm{ft}$., $\$ 1 \mathrm{each}$, $\$ 7.50$ for $10 ; 2$ to $3 \mathrm{ft}$., 75 cts. each, $\$ 6$ for 10 .

\section{CARYOPTERIS}

Caryopteris incana. Common Bluebeard. (S) A Iow, spreading bush, producing clusters of beautiful, blue, fragrant fiowers from September until frost. It dies to the ground here in winter and must be protected if the plant is to continue in a northern climate. 2 -yr., 50 cts. each, $\$ 4.50$ for 10 .

\section{CEPHALANTHUS}

Cephalanthus occidentalis. Common Buttonbush. (M) An excellent shrub for waterside planting as it thrives best in moist, loamy soil. Its creamy white, fragrant flowers are borne in dense round heads in midsummer. 2 to $3 \mathrm{ft}$., $75 \mathrm{cts}$. each, $\$ 6$ for $10 ; 18$ to 24 in., 60 cts. each, $\$ 5$ for 10 .

\section{CLETHRA}

†Clethra alnifolia. Summersweet, Sweet Pepper Bush. (M) A dainty, little, native shrub with spikes of creamy white, fragrant flowers throughout the season. It thrives in shady, damp places, where many shrubs will not grow, and is worthy of a place in every garden. 3 to $4 \mathrm{ft}$., $90 \mathrm{cts}$. each, $\$ 7$ for 10 ; 2 to $3 \mathrm{ft}$., $75 \mathrm{cts}$. each, $\$ 5.50$ for 10 . See illustration.

\section{CORNUS · Dogwood; Cornel}

Prominent among the hardiest and showiest of shrubs are the shrubby Dogwoods. They present a continual display of beauty in flower, leaf, foliage, fruit, and twig that is hard to equal in any other family of shrubs. The common Dogwood of the woods, Cornus florida, is listed under "Deciduous Trees."

$\S+$ Cornus alba. Tatarian Dogwood. (L) An erectstemmed shrub with good, clean foliage and bright blood-red branches making it very showy in shrubberies, especially in winter. 4 to $5 \mathrm{ft}$., 75 cts. each, $\$ 6$ for $10 ; 3$ to $4 \mathrm{ft}$., 60 cts. each, $\$ 4.50$ for 10 . 


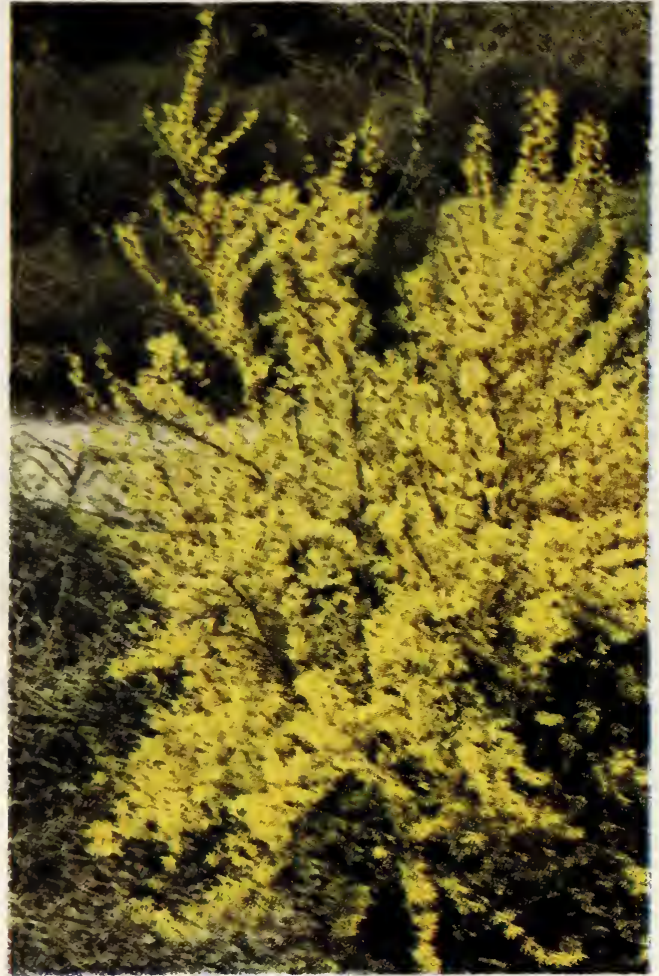

Forsythia spectabilis is the finest of the family and makes the garden gay in very early spring. See page 28

\section{COTONEASTER, continued}

C. horizontalis. Rock Cotoneaster. (Dm) This low shrub, with its almost horizontal branches and smaII glossy green leaves, is becoming used more each year. The flowers are pinkish white and the fruit bright red. While it is one of the very best shrubs for use in a rock garden, it is equally attractive in other spots and for use as ground-cover. No shrub in the garden produces more attractive bright red berries in the autumn than the Rock Cotoneaster. From 6-in. pots, 15 to 18 in., $\$ 1.50$ each, $\$ 13.50$ for 10 ; from 5-in. pots, 9 to 12 in., $\$ 1.25$ each, $\$ 11$ for 10 ; from 5 -in. pots, 6 to 9 in., $\$ 1$ each, $\$ 8$ for 10 .

C. horizontalis perpusilla. Like $C$. horizontalis, one of the finest shrubs for terraces and rockeries. It has smaller leaves and is dwarfer generally. From 5-in. pots, 6 to 9 in., $\$ 1$ each, $\$ 9$ for 10.

C. horizontalis wilsoni. Wilson Cotoneaster. A more arching and diffuse form, generally the tallest of the C. borizontalis type. Quite distinct. From 5-in. pots, 12 to 15 in., $\$ 1.50$ each, $\$ 13.50$ for 10 .

C. moupinensis. Mupin Cotoneaster. Reaches 15 feet at maturity, with thickish leaves, rather longer than most varieties. Flowers pinkish; fruits black. 3 to $4 \mathrm{ft}$., field-grown plants, $\$ 1.50$ each, $\$ 13.50$ for 10 .

C. nitens. Much like $C$. divaricata and equally handsome, but the fruits are shining purple-black. From 5 -in. pots, 15 to 18 in., $\$ 1.25$ each, $\$ 10$ for 10 .

C. racemiflora. One of the hardiest of the family, growing about 4 feet, sometimes lower. Leaves roundish; very free flowering; fruits red. Very handsome. From 5-in. pots, 12 to 15 in., $\$ 1.25$ each, $\$ 10$ for 10 .

C. rotundifolia (prostrata). A low, much-branched, almost prostrate shrub with small flowers and an abundance of red berries. The leaves are round glossy, and very handsome. From 6-in. pots, \$2.25
COTONEASTER, continued

C. simonsi. Simons Cotoneaster. A hardy type from the Himalaya mountains. Bushy; 4 feet high; flowers pinkish, and fruits red. Generally considered one of the most ornamental species. 2 to $3 \mathrm{ft}$., field-grown, \$1 each, \$9 for 10 .

\section{CYDONIA}

Cydonia japonica. Japan Quince. (M) One of the first shrubs to bloom in the spring, and very showy because of its glossy leaves and flowers that vary in color from white to scarlet, followed by quinceshaped, fragrant, golden yellow fruit. It has spreading, spiny branches and makes a handsome flowering hedge. 3 to $4 \mathrm{ft}$., $\$ 1.25$ each, $\$ 11$ for $10 ; 2$ to $3 \mathrm{ft}$., 90 cts. each, $\$ 8$ for 10 .

\section{DEUTZIA}

Few shrubs are of such easy culture and give such universal satisfaction. The dazzling white and soft pink of their myriad blossoms yield many handsome effects in garden or border arrangements.

Deutzia gracilis. Slender Deutzia. (D) The slender, arching branches are profusely covered by pure white flowers in early summer. 18 to 24 in., 90 cts. each, $\$ 7.50$ for $10 ; 15$ to 18 in., 75 cts. each, $\$ 5.50$ for 10 ; 12 to 15 in., 60 cts. each, $\$ 4.50$ for 10 .

D. lemoinei. Lemoine Deutzia. (M) An earlyblooming, vigorous, floriferous shrub, with pure white flowers in great sprays along its stout branches. Makes a desirable flowering hedge. 3 to $4 \mathrm{ft}$., $90 \mathrm{cts}$. each, $\$ 8$ for $10 ; 21 / 2$ to $3 \mathrm{ft}$., 75 cts. each, $\$ 7$ for 10 ; 2 to $21 / 2 \mathrm{ft}$., $60 \mathrm{cts}$. each, $\$ 5.50$ for 10 .

D. scabra plena. Double Rose Deutzia. (L) A vigorous, hardy shrub that in July is covered with close spikes of showy, pink-tinged white flowers, when many other shrubs have finished blooming. Worthy of a place in every collection. 3 to $4 \mathrm{ft}$., 60 cts. each, $\$ 5$ for 10 .

D. scabra fortunei. Fortune Deutzia. A notably large-flowered type; very charming and not common. 4 to $5 \mathrm{ft}$., $90 \mathrm{cts}$. each, $\$ 7.50$ for $10 ; 3$ to $4 \mathrm{ft}$., $75 \mathrm{cts}$. each, $\$ 6$ for 10 .

D. scabra crenata, Pride of Rochester. (L) One of the tallest and best Deutzias. The large, double white flowers, with the backs of the petals tinged rose, are borne in great profusion in July. 4 to $5 \mathrm{ft}$., 75 cts. each, $\$ 6$ for $10 ; 3$ to $4 \mathrm{ft}$., 60 cts. each, $\$ 5$ for 10 .

D. scabra watereri. Waterer Deutzia. (L) A beautiful variety with large, double pink flowers in July. 2 to $3 \mathrm{ft}$., 75 cts. each, $\$ 6.50$ for 10 .

\section{DIERVILLA}

Diervilla trifida. Dwarf Busb-Honeysuckle. (D) An excellent shrub for low masses on large estates, but not so desirable for other purposes as the true weigelas which belong to the same botanic group. Bears a profusion of loose, yellow flowers in June. 2 to $21 / 2 \mathrm{ft}$., 60 cts. each, $\$ 5$ for 10 .

\section{ELÆAGNUS • Oleaster}

†Elæagnus angustifolia. Russian Olive. (L) A spreading, somewhat spiny bush, with woolly leaves and fragrant yellow flowers. Especially good for the seashore. Very attractive when in fruit. 2 to $3 \mathrm{ft}$., $50 \mathrm{cts}$. each, $\$ 4$ for 10.

If you have planting problems, we suggest that you consult a landscape architect. Write to us and we will give you the names of several. Experience convinces us that the best results can be obtained, if you are not familiar with plant material, by consulting a competent landscape architect. The landscape architect stands in practically the same relation to us, or any nursery, as the physician does to a drug store. If there are any questions regarding your planting problems that you would like to have us answer, we shall be pleased to do so. 


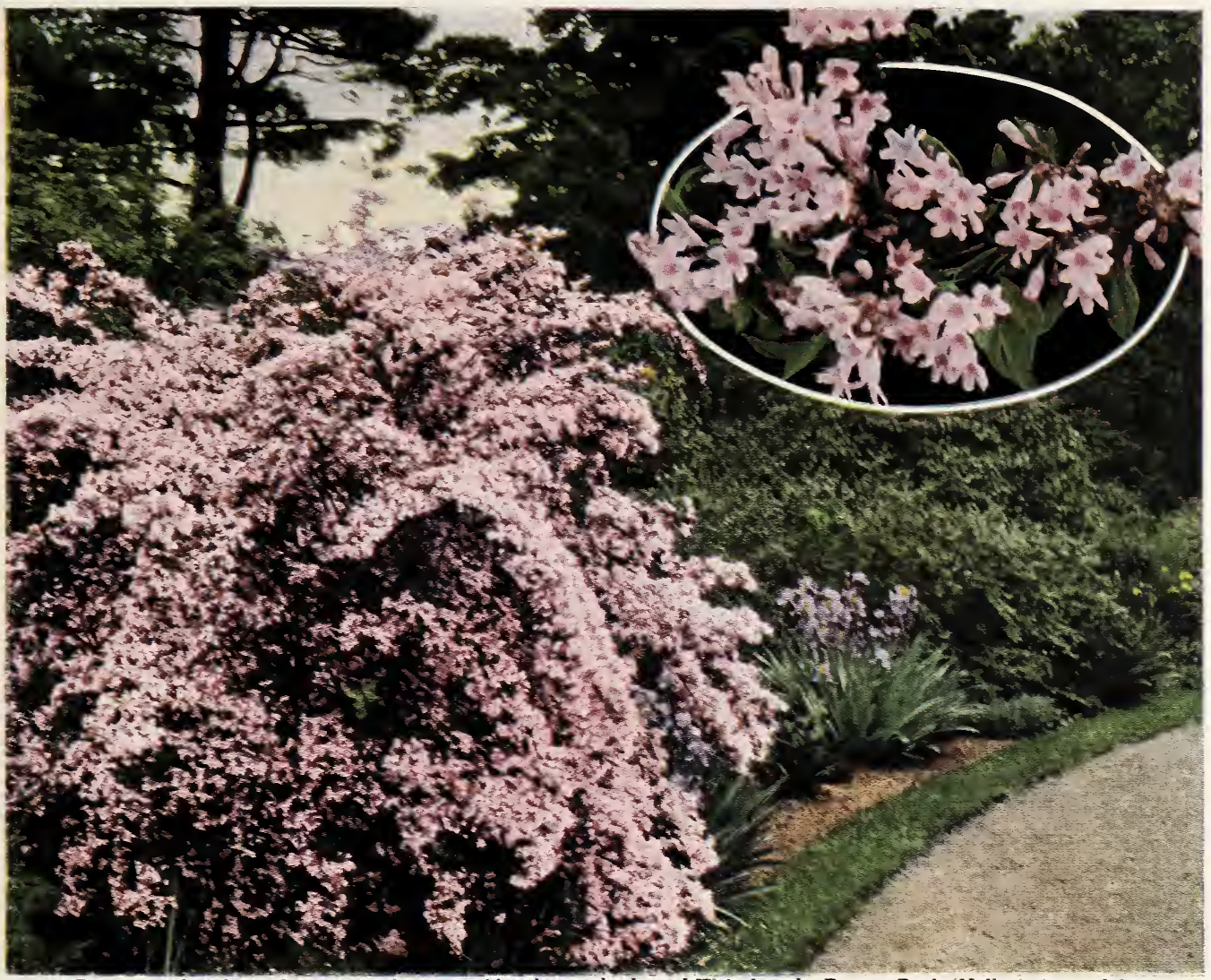

Prettier and with a refinement undreamed of by the much-planted Weigelas, the Beauty Bush (Kolkwitzia amabilis) is one of the most popular new shrubs.

ELAEAGNUS, continued

E. longipes. Cberry Elæagnus. (M) This very desirable shrub has reddish brown branchlets, foliage dark green above, silvery beneath, and yellowish white, fragrant flowers followed by edible scarlet fruit. It is showy and attractive at all times, particularly when in fruit, and is one of the comparatively few decorative shrubs which thrive in the neighborhood of salt water. 3 to $4 \mathrm{ft}$., $\$ 1.50$ each, $\$ 13.50$ for $10 ; 2$ to $3 \mathrm{ft}$., $\$ 1.25$ each, $\$ 11$ for 10 .

\section{ENKIANTHUS}

Enkianthus campanulatus. Bell-flouered Enkiantbus. A neat shrub with branches in whorls like a series of umbreIlas, which later beccmes a small tree. The pinkish striped flowers are like large lilies-of-the-valley and hang in clusters something like those of the styrax. The foliage is its greatest attraction, turning to brilliant shades of pink, red, scarlet, orange, yellow and all sorts of intermediate shades. This is a sour-soil shrub which hates lime, and needs treatment similar to that given azaleas. 9 to 12 in., \$2 each.

\section{EUONYMUS • Strawberry Tree}

Several other varieties of Euonymus are listed under Evergreen Shrubs.

†uonymus alatus. Winged Euonvmus. (M) Most desirable shrub of dwarf, compact habit, with yellowish flowers, followed by red fruit. The foliage is brilliant red in autumn. 3 to $4 \mathrm{ft}$., $\$ 2$ each, $\$ 18$ for $10 ; 2$ to $3 \mathrm{ft}$., $\$ 1.50$ each, $\$ 13.50$ for 10 .

E. alatus compacta. Dwarf Winged Euonymus. A dwarf form of the above. A very choice compact shrub which is new and very desirable. 3 to $31 / 2 \mathrm{ft}$ $\$ 3.50$ each; 18 to 24 in., $\$ 2$ each, $\$ 18$ for 10 .

\section{EUONYMUS, continued}

E. americanus. Brook Euonvmus. An upright shrub, growing to 8 feet, with attractive foliage, reddish flowers, and showy pink fruits. 3 to $4 \mathrm{ft}$., $\$ 1$ each, $\$ 8$ for 10 .

E. bungeanus. Winterberry Euonymus. A slender shrub 15 feet or more high, particularly handsome when covered by its bright orange fruits. 2 to $3 \mathrm{ft}$., 75 cts. each, $\$ 6$ for 10 .

$\dagger$ E. europæus. European Burning Busb. (L) An erect shrub which sometimes makes a small, compact tree. Its foliage is dark green, turning crimson in the fall, and its flowers yellowish, followed by decorative spravs of orange-scarlet fruit. 4 to $5 \mathrm{ft}$., $\$ 1.50 \mathrm{each}$, $\$ 13.50$ for $10 ; 3$ to $4 \mathrm{ft}$., $\$ 1.25$ each, $\$ 10$ for $10 ; 2$ to $3 \mathrm{ft}$., 75 c. each, $\$ 6.50$ for 10 .

E. latifolius. Broadleaf Burning Busb. (L) Large shrubs or small tree with handsome foliage and yellowish flowers in June. Especially attractive when covered by its large, decorative fruit. 3 to $4 \mathrm{ft}$., $75 \mathrm{cts}$. each, $\$ 6$ for 10 .

E. yedoensis. Yeddo Euonymus. The showiest of all the bush Euonymus family. Leaves frve to six inches long, slightly pendulous, turn brilliant red in fall. Scarlet berries surrounded by pink husks are produced in great profusion. 3 to $4 \mathrm{ft}$., $\$ 1.50$ each, $\$ 13.50$ for 10 .

\section{EXOCHORDA}

Exochorda grandiflora. Common Pearl Busb. (L) This is a Chinese shrub of robust, tree-like growth, producing loose clusters of pure white flowers in May, somewhat like large, translucent orange-blossoms and very attractive. The tree is very beautiful where the climate is not too severe. 3 to $4 \mathrm{ft}$., $\$ 1$ each, $\$ 8$ for $10 ; 2$ to $3 \mathrm{ft}$., 75 cts. each, $\$ 6.50$ for 10 . 


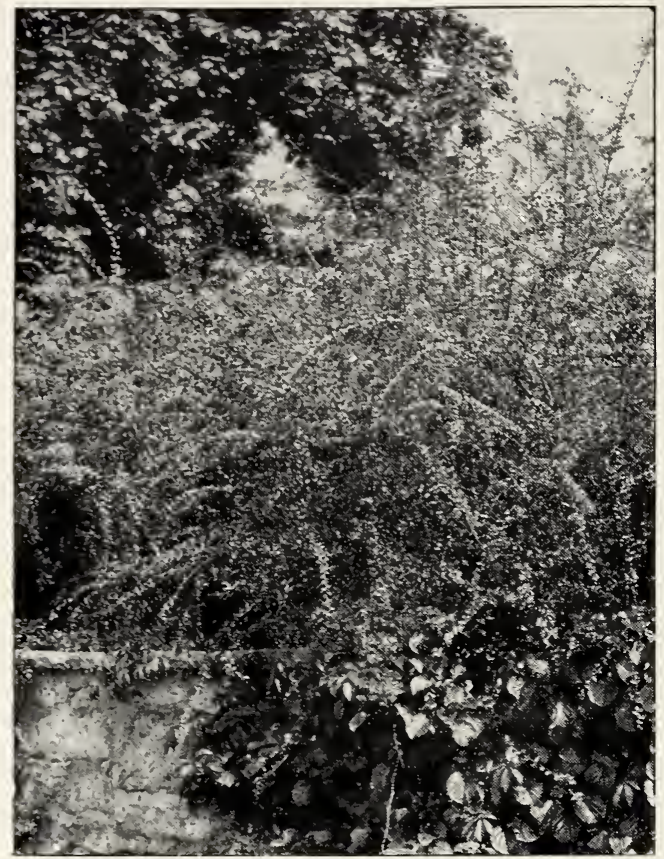

Cotoneaster divaricata (see page 25) above the wall and Hydrangea petiolaris (page 45 ) below

\section{FORSYTHIA • Golden Bell}

Spring is really spring when the Forsythias bloom! Somehow they are the most welcome of the early shrubs because their tender yellow blossoms so definitely belong to that season and no other; and while they seem no stronger than a cloud of yellow butterflies, they defy and defeat winter at the door of spring! One Forsythia shining against a clump of evergreens is a pretty sight, but a clump of them, a border, or a hedge of them is a miracle of loveliness.

†Forsythia intermedia. Border Forsitbia. (L) An erect-growing shrub, but when full grown the branches arch gracefully, and bear clouds of deep yellow flowers. 3 to $4 \mathrm{ft},, 75 \mathrm{cts}$. each, $\$ 6$ for 10 ; 2 to $3 \mathrm{ft}$., $60 \mathrm{cts}$. each, $\$ 4.50$ for 10 .

F. intermedia spectabilis. Sbouy Border Forsytbia. Much more profuse-flowering than the original type, and several shades richer in its glorious deep yellow. Plants vigorous and compact. Regarded by the Arnold Arboretum and all others who have grown it as the finest member of the family. A bush of it, when allowed to grow naturally into its splendid mounded form and magnificent size, is a glorious sight in early spring, every branchlet and twig, from top to bottom, completely buried in flowers. 3 to $4 \mathrm{ft}$., \$1 each, \$7.50 for 10 .

†F. suspensa. Weeping Forsytbia. (L) This variety has long, drooping branches, with bright yellow flowers early in April. 3 to $4 \mathrm{ft}$., $75 \mathrm{cts}$. each, $\$ 6.50$ for $10 ; 2$ to $3 \mathrm{ft}$., $60 \mathrm{cts}$. each, $\$ 5$ for 10 .

†F. suspensa fortunei. Forlune's Forsitbia. (L) The upright branches of this shrub are covered with a profusion of rich yellow flowers and later by broad, deep green foliage. 4 to $5 \mathrm{ft}$., $90 \mathrm{cts}$. each, $\$ 7.50$ for $10 ; 3$ to $4 \mathrm{ft}$., $75 \mathrm{cts}$. each, S6 for 10.

tF. viridissima. Greenstem Forsutbia. (M) A more bushy shrub than the other varieties. Its foliage is rich green and it blooms less profusely and somewhat later than the other sorts. $1 \mathrm{t}$ is fine for prolonging the verv desirable Forsythia season. 4 to $5 \mathrm{ft}$., $90 \mathrm{cts}$. each, $\$ 7$ for $10 ; 3$ to $4 \mathrm{ft}$., $75 \mathrm{cts}$. each, $\$ 6$ for 10 .

\section{GENISTA}

†Genista tinctoria. Woadwaxen. (M) The pretty, golden yellow blossoms come in June and attract much attention when the plants are grown in masses. It is a very good shrub for rockeries and dry hills or for planting banks. It does especially well in poor, thin soil, where nothing else can be made to grow. 2 to $3 \mathrm{ft}$., $60 \mathrm{cts}$. each, $\$ 5$ for 10 .

\section{HALESIA}

Halesia tetraptera carolina. Great Silverbell. (L) A very vigorous shrub which eventually becomes a small tree. It is a native of the Blue Ridge Mountains. The beautiful, white, bell-like flowers are borne profusely in May, making a distinctly handsome effect. The foliage is beautifully and vividly colored in autumn, giving it great landscape value. 4 to $5 \mathrm{ft}$., $\$ 1.25$ each, $\$ 11$ for $10 ; 3$ to $4 \mathrm{ft}$., $\$ 1$ each.

\section{HAMAMELIS}

Hamamelis vernalis. Vernal Witcb-Hazel. Attractive winter-blooming shrub with bright yellow flowers in January, February, or March, which are not injured by zero weather. A shrub of unusual interest for its curious flowers and strange blooming season. Grows about 6 feet high. 3 to $4 \mathrm{ft}$., $\$ 2.50$ each, $\$ 22.50$ for $10 ; 2$ to $3 \mathrm{ft}$., $\$ 2$ each, $\$ 18$ for 10 .

H. virginiana. Common Witch-Hazel. (L) Another native shrub much like the hazel. Its queer yellow flowers appear in November after the leaves have fallen. 3 to $4 \mathrm{ft}$., 90 cts. each, $\$ 8$ for $10 ; 2$ to $3 \mathrm{ft}$., 75 cts. each, $\$ 6.50$ for 10 .

\section{HIBISCUS SYRIACUS}

\section{Althæa; Rose of Sharon}

These are sturdy, tree-like shrubs that wait until the others are through blooming and then they have the landscape to themselves to make it merry with their many flowers of pink, and white, and violet. Late July and August finds them at their best. They are splencid to border a drive, for specimens, or for backgrounds. Not hardy north of Boston.

Anemonæflorus. (L) Double white flowers with a richly tinted center.

Ardens. Double; intense purplish blue.

Boule de Feu. Semi-double; violet-red flowers.

Duchesse de Brabant. (L) This double pink variety is needed in every collection.

Jeanne d'Arc. (L) A very strong-growing shrub, producing double white flowers.

Lady Stanley. (L) One of the most attractive of our collection. Double, blush-white flowers, with a dark center.

Rubis. Single red.

Snowstorm (Totus albus). (M) Produces single pure white flowers. A dwarf grower which makes a beautiful hedge.

Prices of above varieties, 3 to $4 \mathrm{ft}$., $75 \mathrm{cts}$. each, $\$ 7$ for 10

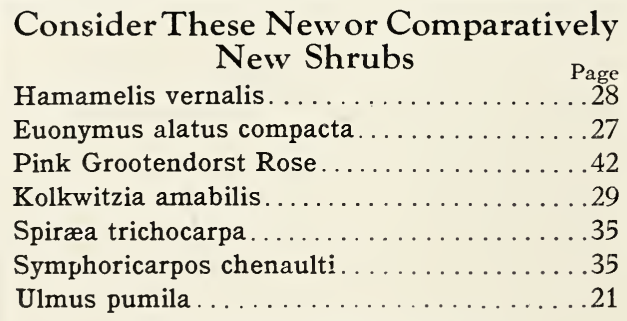

Plant one or more this year 


\section{HYDRANGEA}

The enormous production of big bold flowers and the long time ther remain in attractive condition have earned the Hydrangeas an almost limitless popularity. Few plants are more satisfactory around homes and for display on large estates or parks.

Hydrangea arborescens grandiflora. Snoubill Hydrangea. Its large clusters of pure snow-white flowers, averaging 4 to 5 inches in diameter, appear from June to the middle of September. Suitable for shady as well as sunny positions. 3 to $4 \mathrm{ft}$., $90 \mathrm{cts}$. each, $\$ 8$ for $10 ; 2$ to $3 \mathrm{ft}$., 75 cts. each, $\$ 6.50$ for 10 18 to 24 in., 60 cts. each, $\$ 5$ for 10 .

H. paniculata. Panicled Hidrangea. (L) This is a form of the above with single flowers, and in many respects is a much more pleasing shrub, particularly for its gracefulness. Highly recommended in Iandscape planting. It blooms in September, in upright panicles, the flowers creamy white, Iater turning to shades of rose and purple. 3 to $4 \mathrm{ft}$., $\$ 1$ each, $\$ 8$ for $10 ; 2$ to $3 \mathrm{ft}$., 75 cts. each, $\$ 6$ for 10 .

H. paniculata grandiflora. Peegee Hydrangea. (L) This variety is exceedingly well known, being in almost every garden. Its large, conical heads of white flowers become pink and red with age. It should have plenty of water, and be severely pruned every spring in order to produce large flowers. We offer it in both bush and tree form.

Bush form, 3 to $4 \mathrm{ft}$., 90 cts. each, $\$ 7.50$ for 10 2 to $3 \mathrm{ft}$., 65 cts. each, $\$ 5.50$ for $10 ; 18$ to 24 in., 60 cts. each, $\$ 5$ for 10 .

Tree form, 3 to $4 \mathrm{ft}$., $\$ 1.50$ each, $\$ 14$ for 10

H. radiata. Silver-leaved Hydrangea. (M) The Iarge, heart-shaped, bright green foliage of this variety is silvery beneath, and the contrasting colors are decidedly pleasing. The white flowers are borne in flat corymbs. 2 to $3 \mathrm{ft}$., $60 \mathrm{cts}$. each, $\$ 5$ for 10

\section{HYPERICUM • St. John's-Wort}

Hypericum aureum. Golden St. Jobn's-Wort. (S) A showy shrub of stiff, dense habit which prefers moist soil. The foliage is bluish, and the golden vellow flowers are produced from August to October. 2 to $21 / 2 \mathrm{ft}$., $90 \mathrm{cts}$. each, $\$ 7.50$ for $10 ; 18$ to $24 \mathrm{in}$., 75 cts. each, $\$ 6$ for 10.

H. densiflorum. (M) A Iarger variety than the above, with bright yellow flowers from July to September. 2 to $21 / 2 \mathrm{ft}$., 90 cts. each, $\$ 7.50$ for 10 ; 18 to 24 in., 75 cts. each, \$6 for 10.

H. patulum henryi. Henry Hypericum. Dwarf shrub with large, showy golden yellow flowers. Fairly hardy. 15 to 18 in., 75 cts. each, $\$ 7$ for 10.

\section{ILEX • Holly}

For other shrubs of this family, see Evergreen Shrub section.

†Ilex verticillata. Common Winterberry. (L) A very ornamental shrub with upright branches and light green foliage. Its bright scarlet berries are very decorative and remain on the branches until midwinter. 3 to $4 \mathrm{ft}$., $\$ 1.25$ each, $\$ 11$ for $10 ; 2$ to $3 \mathrm{ft}$., $\$ 1$ each, $\$ 8.50$ for 10 .

\section{KERRIA - Globe Flower}

Kerria japonica. Kerria; Globe Flower. (M) An erect, rather tall shrub with Iong, clean stems bearing single, frve-petaled yellow flowers throughout the summer. The foliage becomes yellow in autumn and the plant is decidedly attractive the whole year. 2 to $3 \mathrm{ft}$., $90 \mathrm{cts}$. each, $\$ 8$ for $10 ; 18$ to 24 in., 75 cts. each, \$6 for 10.

K. japonica flore-pleno. Double Kerria. (M) Very double flowers which look like little balls of gold. This bush is more common than the single variety and enjoys the same treatment. It blooms constantly from June to September. 2 to $3 \mathrm{ft}$., $90 \mathrm{cts}$. each, $\$ 8$ for 10 .
KOLKWITZIA • Beauty Bush

Kolkwitzia amabilis. Beauty Bush. A handsome new shrub from Korea, hardy in New England, making Iong sprays of graceful foliage and completely buried in delicate pink flowers like tiny weigela blossoms, tinted with yellow in the throat. One of the finest modern introductions to the shrub list and rapidly becoming very popular. The plants take hold quickly and make rapid growth but do not display their fuIl flowering habit for several years. 2 to 3 $\mathrm{ft}$., $\$ 4$ each, $\$ 37.50$ for $10 ; 18$ to 24 in., $\$ 2.50$ each, $\$ 22.50$ for 10 . These are heavy plants.

\section{LESPEDEZA • Bush Clover}

Lespedeza formosa (sieboldi). Purple Busb Clover. A very desirable plant for its long, drooping racemes of rosy purple flowers in September. The top of the plant dies to the ground in winter, and restores itself rapidly during the summer, producing flowers late in the season at a time when showy flowering shrubs are extremely scarce. 2 -yr. plants, 60 cts. each, $\$ 5$ for 10 .

\section{LIGUSTRUM $\cdot$ Privet}

It seems unnecessary to expatiate upon the merits of Privet. Everybody knows what handsome hedges and screens this valuable group of plants can make when properly planted and trimmed. They grow vigorously in almost any situation, even in fairly dense shade and places where the soil seems always dry.

The plants of the varieties Ibota, Regelianum, and Vulgare are used as shrubs in borders of flowering shrubs and are very effective.

$\dagger$ Ligustrum amurense. Amur Privet. A tall-growing, upright shrub with dark green, lustrous leaves and white flowers like bunches of little white lilacs. Perfectly-hardy. This plant has been used for hedges to a tremendous extent in the past few years and has given general satisfaction. It also forms an excellent quick-growing screen.

4 to $5 \mathrm{ft}$., 75 cts. each, $\$ 5.00$ for $10, \$ 39$ per 100; 3 to $4 \mathrm{ft}$., $60 \mathrm{cts}$. each, $\$ 3.50$ for $10, \$ 24$ per 100 ; 2 to $3 \mathrm{ft}$., 40 cts. each, $\$ 2.50$ for $10, \$ 18$ per 100 .

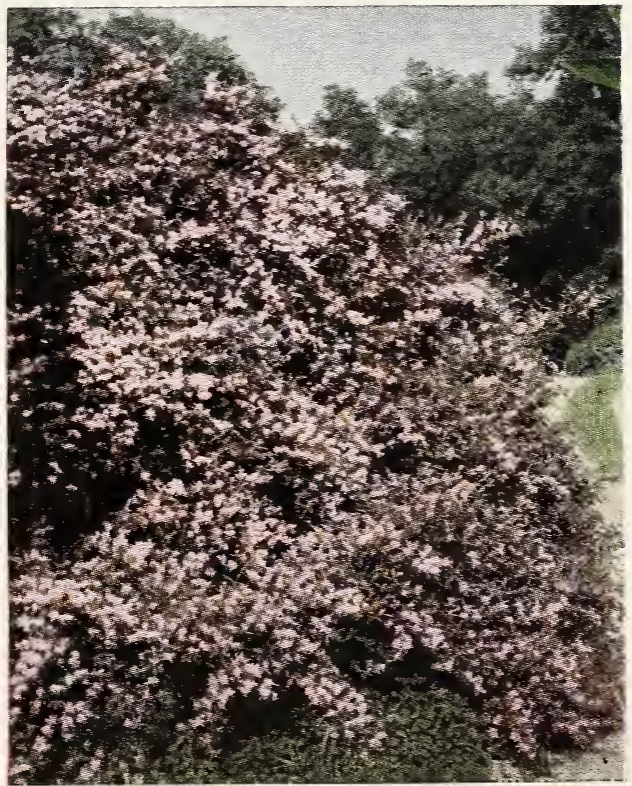

Lonicera tatarica is one of the most floriferous shrubs, and its foliage is feathery and attractive. See page 30 


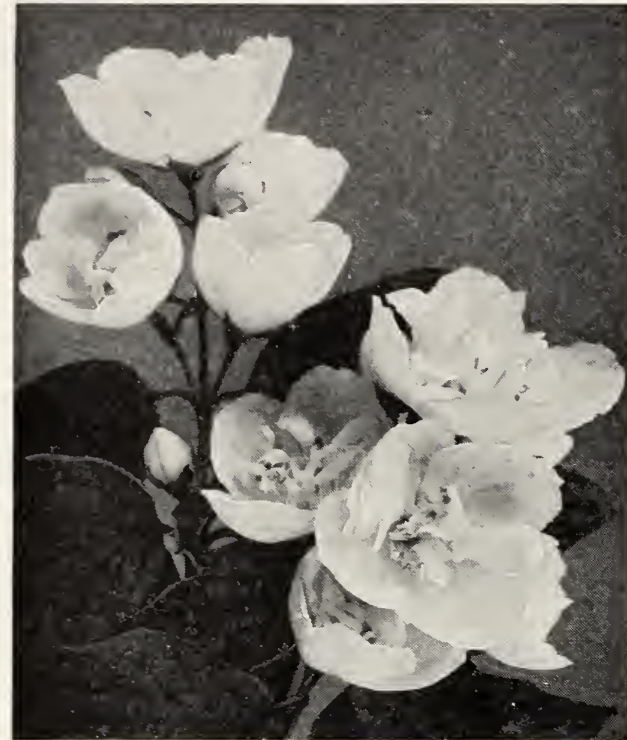

Philadelphus, Virginal, blooms on and off all summer

LIGUSTRUM, continued

$\dagger$ L. ibolium. Ibolium Privet. This is a new hardy Privet, a hybrid between $L$. ibota and $L$. ovalifolium, having the rich, glossy green leaves of the latter and the bushiness and hardiness of the former. It is becoming more popular each year. 3 to $4 \mathrm{ft}$., 50 cts. each, $\$ 4$ for $10, \$ 27$ per $100 ; 2$ to $3 \mathrm{ft}$., $40 \mathrm{cts}$. each, $\$ 3$ for $10, \$ 21$ per 100 .

$\dagger$ L. ibota. Ibota Privet. (L) One of the hardiest and most graceful sorts. It has spreading, curving branches, grayish green leaves, and fragrant white flowers in June, followed by black berries. Useful for specimens, mass planting or hedges. 4 to $5 \mathrm{ft}$., 60 cts. each, $\$ 5$ for $10 ; 3$ to $4 \mathrm{ft}$., 50 cts, each, $\$ 4.50$ for $10, \$ 27$ per $100 ; 2$ to $3 \mathrm{ft}$., 40 cts. each, $\$ 3$ for 10 , $\$ 18$ per 100.

$\dagger$ †. ibota regelianum. Regel Privet. (M) A Iow, absolutely hardy shrub, with almost horizontal branches. It is graceful and sufficiently dense for hedges without trimming. $21 / 2$ to $3 \mathrm{ft}$., $70 \mathrm{cts}$. each. $\$ 6$ for $10 ; 2$ to $21 / 2 \mathrm{ft}$., 60 cts. each, $\$ 5$ for $10, \$ 39$ per $100 ; 18$ to 24 in., 50 cts. each, $\$ 4$ for $10, \$ 33$ per 100 .

†CALIFORNIA PRIVET (Ligustrum ovalifolium). (L) This very handsome shrub is of stiff, upright habit. It transplants easily and is most useful for shrubbery, screens, or hedges. 3 to $4 \mathrm{ft}$., $30 \mathrm{cts}$. each, 32.20 for 10 , \$14 per $100 ; 2$ to $3 \mathrm{ft}$., 25 cts. each, $\$ 1.80$ for 10 , $\$ 12$ per $100 ; 18$ to 24 in., 20 cts. each, $\$ 1.50$ for $10, \$ 10$ per 100 .

Our Privet is heavy transplanted stock, bushy tops and roots

$\dagger$ L. vulgare. European Privet. (L) Very hardy. It has grayish green foliage, white flowers in June followed by clusters of shining black berries. 4 to $5 \mathrm{ft}$., $75 \mathrm{cts}$. each, $\mathrm{S} 6$ for $10 ; 3$ to $4 \mathrm{ft}$., $50 \mathrm{cts}$. each, $\$ 4$ for $10, \$ 33$ per $100 ; 2$ to $3 \mathrm{ft}$., 40 cts. each, $\$ 3$ for 10 . $\$ 27$ per 100 .

\section{LONICERA • Bush Honeysuckle}

Graceful shrubs with interesting foliage and habit, charming flowers, in many cases very fragrant, and delightful berries. The climbing Honeysuckles will be found under Lonicera in the section devoted to Vines and Climbing Plants.

\section{LONICERA, continued}

\$Lonicera bella albida. Wbite Belle Honeysuckle. (M) A strong, rapidly growing shrub, bearing a profusion of white flowers and scarlet fruits. 4 to $5 \mathrm{ft}$., 75 cts. each, $\$ 6.50$ for $10 ; 3$ to $4 \mathrm{ft}$., $60 \mathrm{cts}$. each, $\$ 5$ for 10 .

§L. fragrantissima. Winter Honeysuckle. (M) This strong-growing bush reaches a height of 8 feet, with very fragrant, creamy white flowers in early spring. 2 to $3 \mathrm{ft}$., $75 \mathrm{cts}$. each, $\$ 6$ for 10 .

L. maacki. Amur Honeysuckle. A very large and attractive shrub with grayish foliage and graceful branches. Very handsome as a specimen and a very quick-growing subject for the shrub-border. Scarlet berries. 3 to $4 \mathrm{ft}$., $\$ 1$ each, $\$ 8$ for $10 ; 2$ to $3 \mathrm{ft}$., 75 cts. each, $\$ 6.50$ for 10 .

L. maacki podocarpa. Late Honeysuckle. A somewhat dwarfer and more spreading type of handsome form. Very showy and beautiful in fruit. 3 to $4 \mathrm{f}$.., $\$ 1.25$ each, $\$ 11$ for 10 .

$\dagger \S$ L. morrowi. Morrow's Honeysuckle. (M) A shrub with wide-spreading branches and leaves which are dark green above and grayish beneath. The creamy white flowers in May and June are followed by bright red fruits ripening in August and lasting until late in the fall. Very decorative. 4 to $5 \mathrm{ft}$., $75 \mathrm{cts}$. each, $\$ 6$ for $10 ; 3$ to $4 \mathrm{ft}$., $60 \mathrm{cts}$. each, $\$ 5$ for 10 .

\$L. ruprechtiana. Mancburian Honeysuckle. (L) Another particularly desirable shrub because of its yellowish white flowers in June, and showy red fruit in autumn. It grows 12 feet high and has attractive and graceful habit with an abundance of dark green foliage that is grayish beneath. 4 to $5 \mathrm{ft}$., $75 \mathrm{cts}$. each, $\$ 6$ for $10 ; 3$ to $4 \mathrm{ft}$., $60 \mathrm{cts}$. each, $\$ 5$ for 10 .

§L. tatarica. Tatarian Honeysuckle. (L) A big, graceful bush that bears a profusion of pink flowers in June, which show up well against the foliage. These are followed by an abundance of light red berries. It flourishes in partial shade. 4 to $5 \mathrm{ft}$., 75 cts. each, $\$ 6$ for $10 ; 3$ to $4 \mathrm{ft}$., $60 \mathrm{cts}$. each, $\$ 4.50$ for 10 .

$\dagger$ \&. tatarica alba. White Tatarian Honeysuckle. (L) Similar to L. tatarica, but has large, pure white flowers and crimson fruit. 4 to $5 \mathrm{ft}$. $75 \mathrm{cts}$. each, $\$ 6$ for $10 ; 3$ to $4 \mathrm{ft}$., 60 cts. each, $\$ 5$ for 10 .

L. tatarica grandiflora rosea. Flowers somewhat larger than the preceding, delicately tinted pink with deeper edges. 4 to $5 \mathrm{ft}$., 75 cts. each, $\$ 6$ for 10 .

\section{MYRICA • Wax Myrtle}

$\dagger \S$ Myrica carolinensis. Nortbern Bayberry. (M) A low, spreading native shrub which thrives in sandy places. It is a sub-evergreen, much admired for its dark green, fragrant foliage. The flowers are inconspicuous, but are followed by charming white, waxy berries. A most desirable native shrub. 18 to 24 in., $\$ 1$ each, $\$ 8$ for $10 ; 15$ to 18 in., 75 cts. each, $\$ 6.50$ for $10 ; 12$ to 15 in., 60 cis. each, $\$ 5$ for 10 .

\section{NEMOPANTHUS}

†Nemopanthus mucronatus. Mountain Holly. (L) An ornamental, upright shrub grown for its attractive fruit and medium-sized, bright green leaves. It produces inconspicuous whitish flowers in May and June and attractive red fruit on slender, drooping stalks in August and September. 4 to $5 \mathrm{ft}$., 75 cts. each; 3 to $4 \mathrm{ft}$., 60 cts. each.

\section{PHILADELPHUS • Mock Orange}

For some curious reason the Philadelphuses were confused a long time ago with the Syringas, which is the proper name of the lilacs, and many people still refer to the old-fashioned Mock Orange as Sweet Syringa. But whatever their name they are charming shrubs, with deliciously fragrant flowers, for most part, and deserve an honored place in every shrub collection. 


\section{PHILADELPHUS, continued}

$\lceil$ Philadelphus coronarius. Sueet Mock Orange. (L) This tall-growing shrub, with upright branches, has a great profusion of pure white, delightfully fragrant flowers in June and handsome, dark green foliage. It makes a good hedge in partly shady places. 5 to $6 \mathrm{ft}$., $90 \mathrm{cts}$. each, $\$ 7.50$ for $10 ; 4$ to $5 \mathrm{ft}$. 75 cts. each, $\$ 6$ for $10 ; 3$ to $4 \mathrm{ft}$., 60 cts. each, $\$ 4.50$ for 10 .

P. coronarius foliis aureis. Golden Mock Orange (D) A graceful, dwarf variety, with bright yellow foliage which retains its color throughout the season, making it very effective for contrast in shrubbery plantings. 18 to 24 in., 90 cts, each, $\$ 8$ for $10 ; 15$ to 18 in., 75 cts. each, $\$ 7$ for 10 .

$\uparrow$ P. gordonianus. Gordon Mock Orange. (L) Very rapid-growing variety with gravish brown branches and large, pure white flowers that come later than the other sorts. 3 to $4 \mathrm{ft}$., $60 \mathrm{cts}$. each, $\$ 5$ for 10 .

$\dagger$ P. grandiflorus. Big Scentless Mock Orange. (L) A vigorous variety, with large, white, showy flowers in June. It grows rapidly although its branches are somewhat straggling. 4 to $5 \mathrm{ft}$., $75 \mathrm{cts}$. each, $\$ 5$ for $10 ; 3$ to $4 \mathrm{ft}$., $60 \mathrm{cts}$. each, $\$ 4$ for 10 .

\section{Hybrid Varieties of Mock Orange}

These comprise some of the finest highly developed sorts that have come from the hands of the famous Lemoine of France. They are great improvements over the old types, and need only to be better known to be universally admired.

Avalanche. (M) A very handsome shrub, with slender, drooping branches covered almost the whole length with showy white flowers, whereby it justifies its name. 2 to $3 \mathrm{ft}$., 75 cts. each, \$6 for 10 .

Brachybotrys. A new hybrid with tall stems covered by large, pure white flowers. 3 to $4 \mathrm{ft}$., $\$ 1.50$ each $\$ 14$ for 10 .

\section{HYBRID VARIETIES, continued}

Lemoine. (M) This choice variety produces fragrant, pure white flowers in clusters in June. It is very desirable for shrub plantings. 3 to $4 \mathrm{ft}$., $90 \mathrm{cts}$. each, $\$ 7.50$ for $10 ; 2$ to $3 \mathrm{ft}$., 75 cts. each, $\$ 6$ for 10 .

Mont Blanc. (D) Charming dwarf sort, with very large, fragrant flowers, produced in great abundance. This would be a good variety with which to begin a collection of Philadelphuses. Few people realize what a wonderful difference there is between these new hrbrids of Lemoine and the old Mock Orange. A whole new range of garden enjoyment is opened by these delightful hardy shrubs, which produce such an abundance of charming, fragrant flowers. Mont Blanc is one of the best of them. 3 to $4 \mathrm{ft}$., $90 \mathrm{cts}$. each, $\$ 7.50$ for $10 ; 2$ to $3 \mathrm{ft}$., 75 cts. each, $\$ 6$ for 10 .

Virginal. A handsome, erect shrub which covers itself with very large semi-double flowers in June and continues to bloom at the tips of the new shoots all summer and fall. Next to the fragrant old-time $P$. coronarius, it is the favorite of all lovers of these beautiful shrubs. We do not hesitate to recommend this variety to everyone. In sheer beauty and profusion cf bloom it equals the best, and its habit of blooming a little in summer and autumn is an entirely different and valuable character. It ought to be in every garden. 3 to $4 \mathrm{ft}$., $\$ 1.25$ each, $\$ 10$ for 10 ; 2 to $3 \mathrm{ft}$., $\$ 1$ each, $\$ 8$ for 10 .

\section{PHYSOCARPUS}

Physocarpus opulifolius. Common Ninebark. (L) Strong-growing shrub with white flowers along the stems, from which the bark hangs in long shreds and strips. A splendid plant for shady places. 4 to $5 \mathrm{ft}$., $60 \mathrm{cts}$. each, $\$ 5$ for $10 ; 3$ to $4 \mathrm{ft}$., $50 \mathrm{cts}$. each, $\$ 4$ for 10.

†P. opulifolius aureus. Goldleaf Ninebark. (L) Similar to $P$. opulifolius, but has bright yellow foliage. 4 to $5 \mathrm{ft}$., $60 \mathrm{cts}$. each, $\$ 5$ for $10 ; 3$ to $4 \mathrm{ft}$., 50 cts. each, $\$ 4$ for 10.

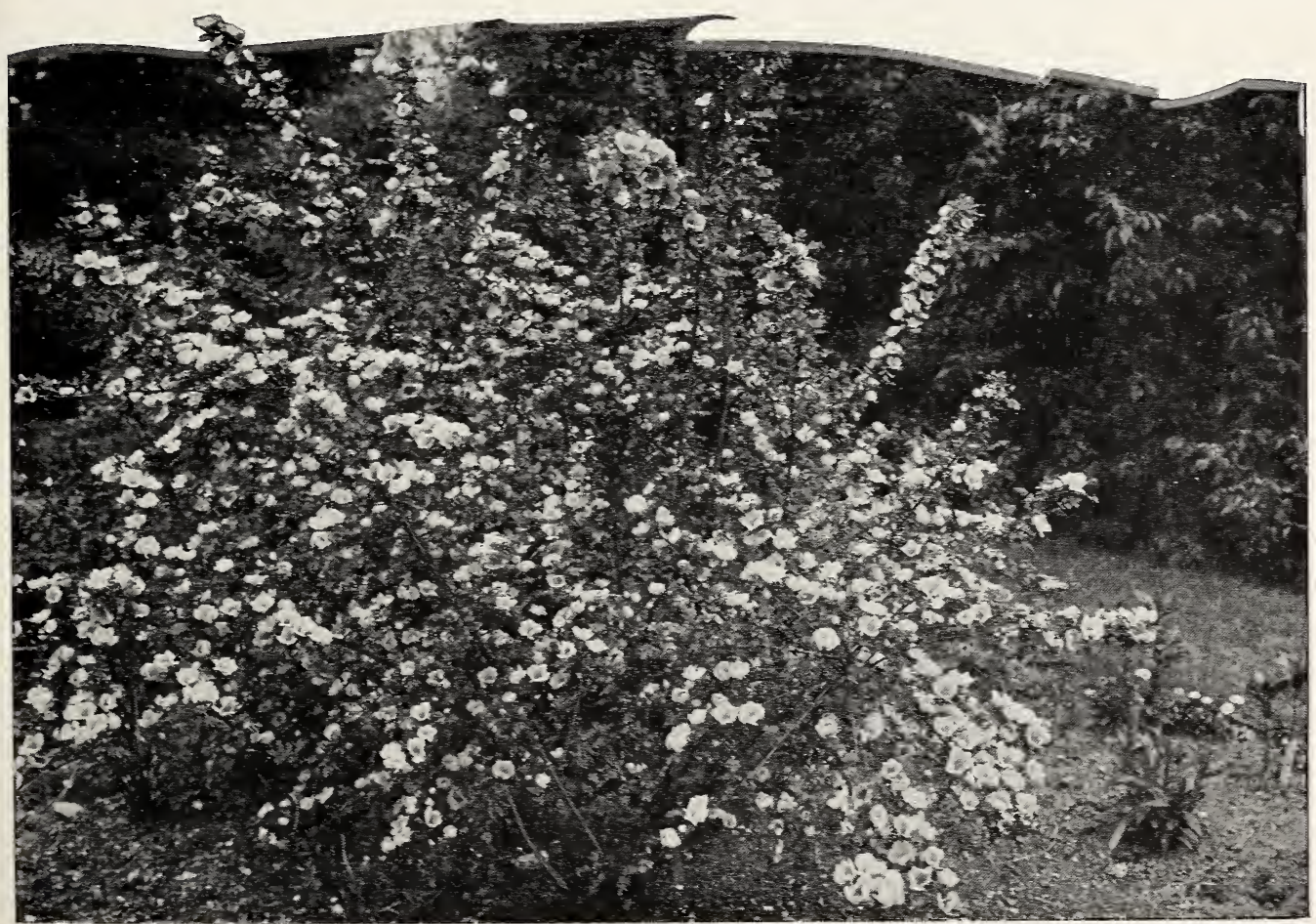

Rosa hugonis. Delightfully informal, with myriads of exquisite flowers long before other Roses bloom. See page 33 


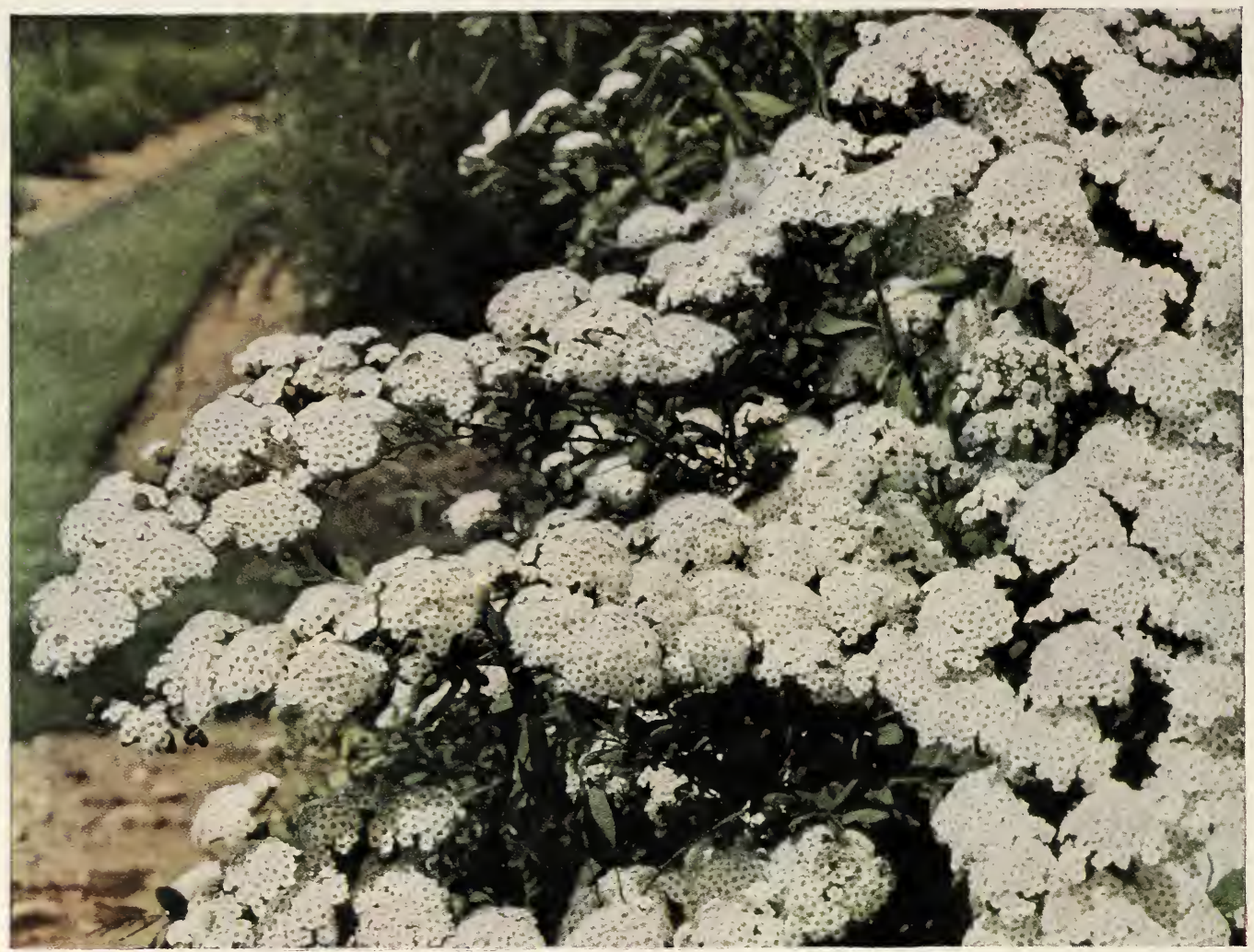

Spiræa trichocarpa. Korean Spirea. Larger and showier than the famous Van Houtte Spirea, and a very valuable new shrub. See page 35

\section{POTENTILLA}

Potentilla fruticosa. Shrubby Cinquefoil. (M) A smallish shrub producing numerous, bright yellow flowers throughout the summer. It thrives in either dry or wet soil and is excellent for rockeries. 2 to $3 \mathrm{ft}$., 90 cts. each, $\$ 7.50$ for $10 ; 18$ to 24 in., 75 cts. each, $\$ 6$ for 10 .

\section{PRUNUS • Plum and Almond}

This is a group of delightful, early-flowering shrubs and small trees beaming with beauty and cheerfulness. Their earliness commends them to all discriminating planters. Certain tree-forms will be found under "Deciduous Trees."

Prunus glandulosa albiplena. Double Pink-flowering Almond. (M) Produces very double, rosecolored flowers in great profusion in the spring. One of the most charming early-flowering shrubs. 3 to $4 \mathrm{ft}$., $\$ 1.25$ each, $\$ 10$ for $10 ; 2$ to $3 \mathrm{ft}$., $\$ 1$ each, $\$ 8$ for 10 .

P. glandulosa sinensis. Double White-flowering Almond. (M) Similar to the pink variety but produces an abundance of double white flowers in May. 3 to $4 \mathrm{ft}$., $\$ 1.25$ each, $\$ 10$ for 10 .

†\$P. maritima. Beacb Plum. (S) A handsome thorny plant, of picturesque growth and spectacularly beautifuI when covered with its billows of shining white flowers in early spring. Desirable shrub for seaside planting and bleak situations. It grows much taller inland and frequently becomes a small tree. 2 to $3 \mathrm{ft}$., 75 cts. each, $\$ 6.50$ for 10 ; 18 to 24 in., 60 cts. each, \$5 for 10

P. triloba. Flowering Plum. (M) A vigorous shrub, having broad, pointed leaves and delightful light pink, double flowers in early spring. 3 to $4 \mathrm{ft}$., $\$ 1$ each, \$9 for 10 .
PRUNUS, continued

P. virginiana. Common Cboke Cherry. (L) Bush or small tree, with rough speckled bark. The fragrant flowers appear in the spring with the leaves in long finger-like racemes, and are followed by red fruit in the summer. 3 to $4 \mathrm{ft}$., $50 \mathrm{cts}$. each, $\$ 4$ for 10 .

\section{RHAMNUS • Buckthorn}

\$Rhamnus cathartica. Common Buckthorn. (M) Fine spiny shrub, with dark green foliage, white flowers, and small fruits. An excellent hedge plant that thrives in partial shade. 3 to $4 \mathrm{ft}$., $60 \mathrm{cts}$. each, $\$ 5$ for $10 ; 2$ to $3 \mathrm{ft}$., 50 cts. each, $\$ 3.60$ for 10 .

R. frangula. Glossy Bucktborn. A handsome shrub or small tree 12 feet high with dark glossy foliage and glittering red fruit which later turns black. Very hardy and persistent. 3 to $4 \mathrm{ft}$., $60 \mathrm{cts}$. each, $\$ 5$ for 10 .

\section{RHODORA}

Rhodora canadensis. Rbodora. (D) Very closely related to the azaleas, which it resembles, this dwarf shrub is covered with rosy purple flowers appearing in May. In the wild it grows in moist places but it does well in drier locations. It blooms at the same time as Azalea vaseyi. 15 to 18 in., $\$ 2$ each, $\$ 18$ for 10 .

\section{RHODOTYPOS}

†Rhodotypos kerrioides. Jetbead. (M) A bushy shrub from Japan, bearing snowy white flowers in May, followed by shining black berries. It strongly resembles Kerria japonica in all but the color of its flowers. Grows in all soils and in shady places. 3 to $4 \mathrm{ft}$., $90 \mathrm{cts}$. each, $\$ 8$ for $10 ; 2$ to $3 \mathrm{ft}$., $75 \mathrm{cts}$. each, \$6 for 10 . 


\section{RHUS • Sumac}

A family of rather curious, big shrubs that deserves notice wherever boldness and decisiveness of effect are wanted.

†Rhus canadensis. Fragrant Sumac. (M) A spreading shrub with clusters or short spikes of small yellow flowers before the leaves. The thick, fragrant foliage turns dark crimson in autumn. 2 to $3 \mathrm{ft}$. $\$ 1$ each, $\$ 9$ for 10 ; 18 to 24 in., 90 cts. each, $\$ 7.50$ for 10 .

R. cotinus. Common Smoke Tree. (L) A muchadmired shrub for its clouds of purplish misty flowers borne in early June. In the fall the leaves change to brown, red, and yellow. 4 to $5 \mathrm{ft}$., $\$ 1.50$ each; 3 to $4 \mathrm{ft}$., $\$ 1.25$ each, $\$ 10$ for 10 .

tR. glabra. Smootb Sumac. This large shrub has smooth bark and attractive crimson seeds and foliage in autumn. Excellent for masses. 5 to $6 \mathrm{ft}$., 90 cts. each, $\$ 7.50$ for $10 ; 4$ to $5 \mathrm{ft}$., $75 \mathrm{cts}$. each, $\$ 6$ for $10 ; 3$ to $4 \mathrm{ft}$., $60 \mathrm{cts}$. each, $\$ 5$ for 10.

†R. typhina. Staghorn Sumac. (L) A bold tree-like shrub with velvety hairy stems and tropicallooking foliage which turns brilliant scarlet in the fall. Its pointed heads of crimson berries persist all winter. Thrives in poor, rocky soil. Especially fine for hillside planting. 5 to $6 \mathrm{ft}$., $90 \mathrm{cts}$. each, $\$ 7.50$ for $10 ; 4$ to $5 \mathrm{ft}$., 75 cts. each, $\$ 6$ for 10 ; 3 to $4 \mathrm{ft}$., 60 cts. each, $\$ 5$ for 10 .

\section{ROBINIA}

Robinia hispida. Rose Acacia. (M) Highly ornamental shrub, bearing drooping clusters of beautiful rose-colored flowers, like pea-blossoms, on long stems during May and June. Especially attractive in large masses. Will grow in any soil. 3 to $4 \mathrm{ft}$, $\$ 1$ each, $\$ 9$ for $10 ; 2$ to $3 \mathrm{ft}$., $75 \mathrm{cts}$. each, $\$ 6.50$ for 10 .

\section{ROSA}

Wild Roses or Rose Species

The Wild Roses surely merit the attention of everyone. Their delicate fragrance and the fragile beauty of their flowers are one of the most beautiful things in Nature. They vary widely in their habits, from erect, almost climbing plants like Rosa setigera and $R$. multiflora, to flat, almost evergreen creepers like $R$. wichuraiana. The Rugosas are especially fine for bold masses, even on the seashore; and a few Sweetbriers should be intermingled in every shrub planting for the delicious fragrance of their leaves when wet with dew or rain.

§Rosa blanda. Meadow Rose. (M) A slender, erect, red-branched, almost thornless variety, with thin, pale green foliage and single flowers of bright pink, in clusters in May. The stems and red berries are very bright against the winter snow. 2 to $3 \mathrm{ft}$., $75 \mathrm{cts}$. each, $\$ 6$ for 10 .

R. hugonis. Hugonis Rose. This big, arching shrub, with spiny stems, blooms very early in May, in long garlands of bright yellow, single flowers which are followed by red, translucent fruits. The best single yellow Rose for shrub use and especially in the background of the rock garden. Give it a warm, sunny exposure to induce it to flower early. The plant is perfectly hardy. 2 -yr., $\$ 1.25$ each, $\$ 11$ for 10.

$\dagger \S$. lucida. Virginia Rose. (D) A dwarf native variety, with prickly stems, dark green leaves, and single, rosy pink flowers about 2 inches across. It does well on poor soil and is often used for roadside edging. 18 to 24 in., 60 cts. each, $\$ 5$ for 10 .

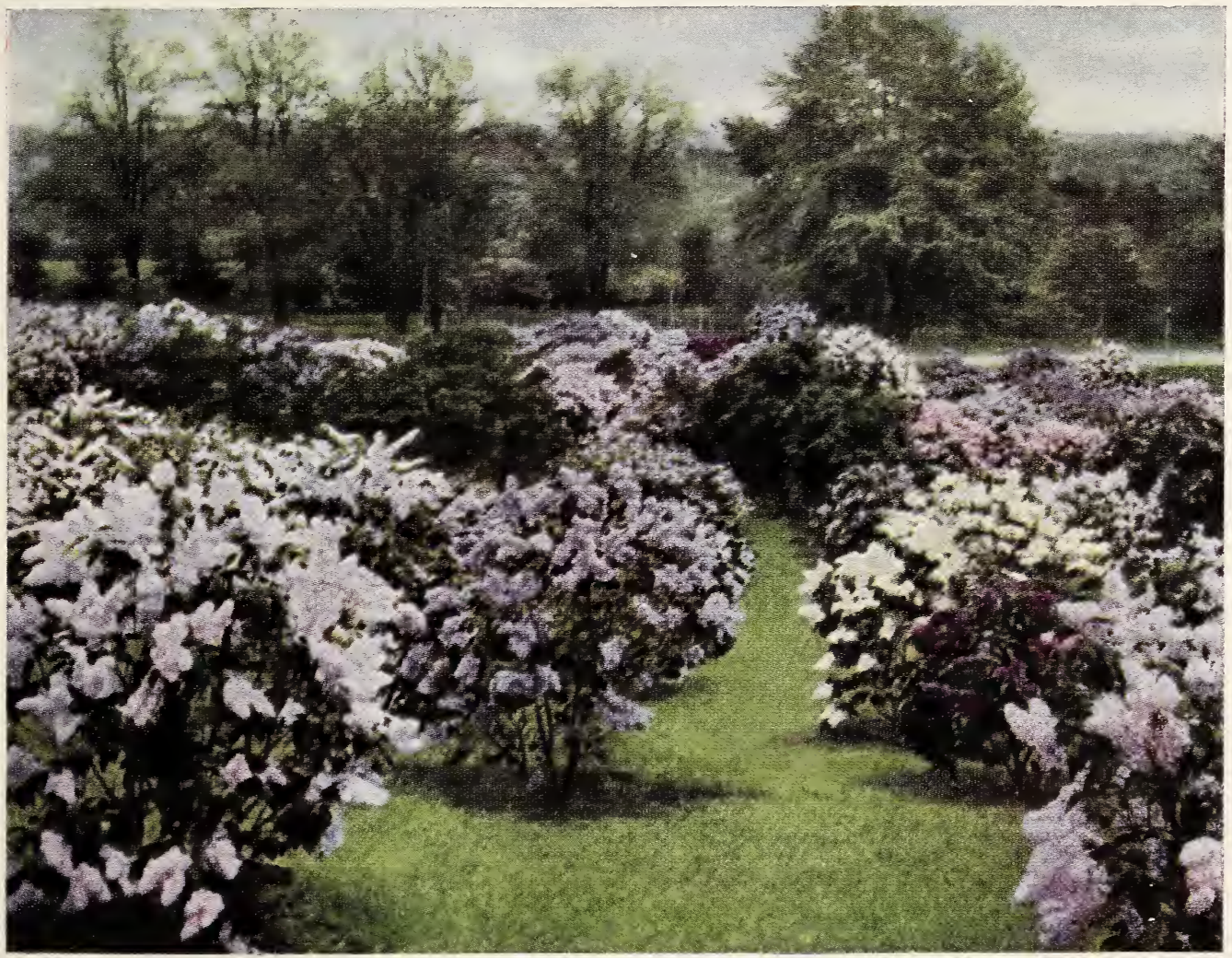

Most people do not realize the variety of color in the marvelous Hybrid Lilacs. See page 36 


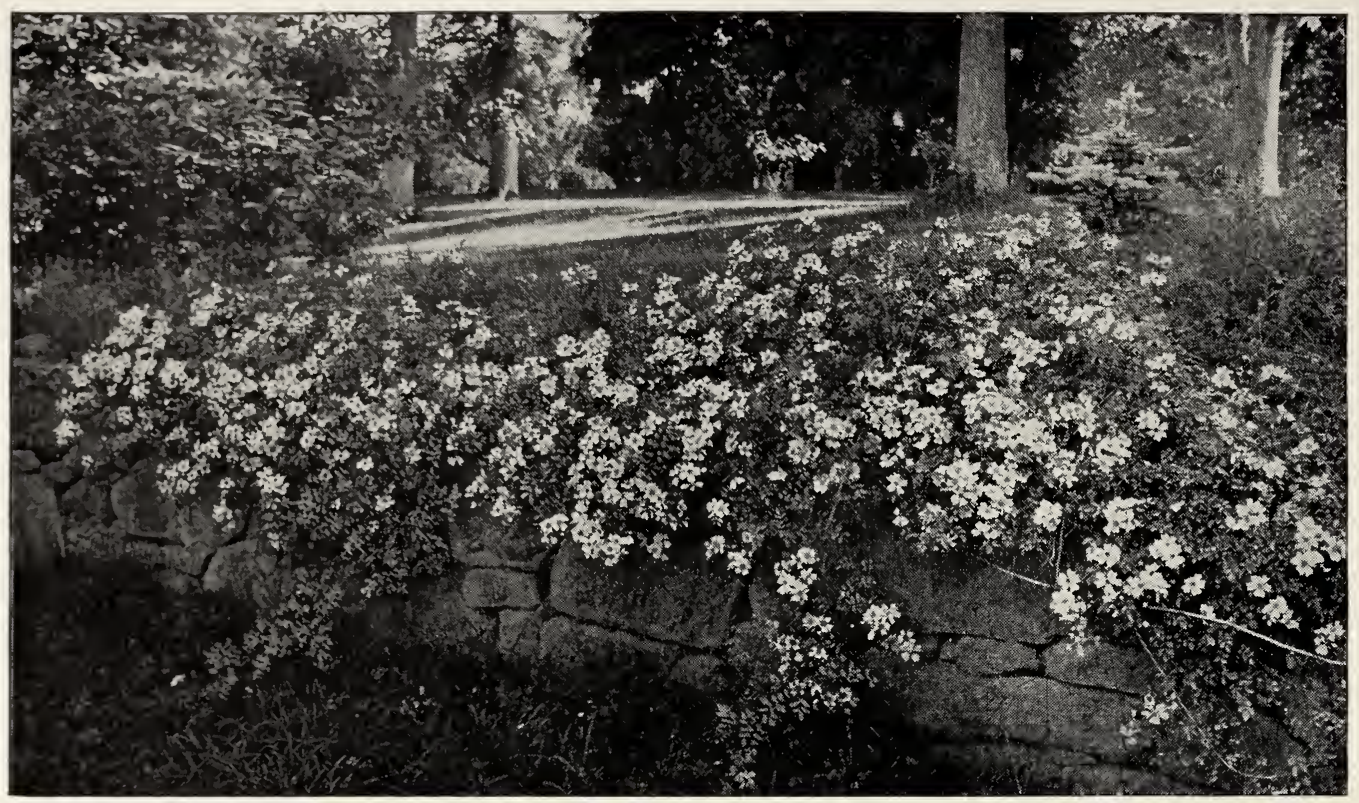

Rosa wichuraiana is beautiful in leaf and habit as well as when in flower

\section{ROSA, continued}

§R. multiflora japonica. Japanese Rose. (L) A Japanese native of rapid growth, forming a round, drooping shrub of fine proportions when standing alone; its proper place, however, is mixed with other shrubbery. Its bunches of single, pure white flowers which look like clustered blackberry blossoms, are produced in great quantities, and are followed by handsome sprays of small scarlet fruits. 3 to $4 \mathrm{ft}$., $60 \mathrm{cts}$. each, $\$ 5$ for 10 .

$\dagger \S$ R. nitida. Bristly Rose. (D) A very dwarf, erect plant whose branches are completely covered with straight prickles and bristles. The foliage is bright green and very glossy, and the flowers bright pink. 18 to 24 in., 50 cts. each, $\$ 4.50$ for 10 .

$\dagger$ R. palustris. Swamp Rose. (L) The tall-growing wild Rose, with single pink flowers produced during the summer months. Its bright red fruit is very showy. This variety is especially adapted to damp ground. 18 to 24 in., $50 \mathrm{cts}$. each, $\$ 4$ for 10.

$\dagger \S$ R. rubiginosa. Sweetbrier Rose. (L) A well-known variety with delicately fragrant foliage and small, pink, fragrant flowers, followed by quantities of bright fruit. It is especially good in a mixed border where its slender sprays of pretty leaves arch above the lower shrubs. 3 to $4 \mathrm{ft}$., 75 cts. each, $\$ 6$ for 10 ; 2 to $3 \mathrm{ft}$., $60 \mathrm{cts}$. each, $\$ 5$ for 10 .

§R. rubrifolia. Red-leaved Rose. (L) Slender, ercet, purplish branches, covered with a bluish bloom. The foliage is bluish green, tinged with red, and is very effective as a colored shrub. Its flowers are tiny and very vivid pink, sparkling like stars. 2 to $3 \mathrm{ft}$., $75 \mathrm{cts}$. each, $\$ 6.50$ for $10 ; 18$ to 24 in., 60 cts. each, $\$ 5$ for 10.

$\dagger \S$ R. rugosa. Rugosa Rose. (L) A stout, upright shrub, 6 to 8 feet high, densely covered with prickles, and having bold, wrinkled foliage, immune to insects and disease. The flowers are very large, single, usually purplish red, and very fragrant, followed by crimson-scarlet fruit. 2 to $3 \mathrm{ft} .60 \mathrm{cts}$. each, \$5 for $10, \$ 39$ per $100 ; 18$ to 24 in., 50 cts. each, $\$ 4.50$ for $10, \$ 33$ per 100

†R. rugosa alba. White Rugosa Rose. (L) The habit and foliage are similar to the prececling, but the fragrant flowers are pure white. Makes a splendid flowering hedge, particularly at the seashore. 18 to 24 in., 60 cts. each, \$5 for 10.

\section{ROSA, continued}

FR. setigera. Prairie Rose. (L) Large, single flowers of deep rose-color. It is a straggly climber, and when trained over the veranda of a rustic cottage, it makes a beautiful display. Especially handsome on stone piles or walls, and is perfectly at home in a fence corner. 3 to $4 \mathrm{ft}$., $60 \mathrm{cts}$. each, $\$ 4.50$ for $10 ; 2$ to $3 \mathrm{ft}$., $50 \mathrm{cts}$. each, $\$ 4$ for 10 .

R. spinosissima. Scotch Rose. A low-growing, very spiny bush, covered in spring with a mass of smaII, single white flowers. Very attractive because of its dense habit and beautiful foliage. 2 to $21 / 2 \mathrm{ft}$., 90 cts. each, $\$ 8$ for 10 ; 18 to 24 in., 75 cts. each, $\$ 6.50$ for 10 .

$\nmid$ R. wichuraiana. Wichurian Rose. (D) Used extensively for covering embankments and stonework, as it creeps rapidly over the surface, forming a mat of glossy foliage. The flowers are pure white, borne in clusters late in the season, and are very fragrant. 3-yr., 75 cts. each, $\$ 6$ for 10 ; 2 -yr., 60 cts. each, $\$ 4.50$ for 10 .

\section{RUBUS}

Rubus odoratus. Flowering Raspberry. (M) A low shrub with very Iarge foliage and showy rosy purple blossoms in clusters, followed by large, flattish red fruits. Excellent for massing under trees and on steep banks. 2 to $3 \mathrm{ft}$., $50 \mathrm{cts}$. each, $\$ 4$ for 10.

\section{SAMBUCUS • Elder}

†Sambucus canadensis. American Elder. (L) A well-known, very hardy native shrub with big, light green foliage, flat heads of creamy white flowers of the utmost daintiness and charm in June and July, followed by reddish purple berries in autumn. 3 to $4 \mathrm{ft}$., $60 \mathrm{cts}$. each, $\$ 5$ for $10 ; 2$ to $3 \mathrm{ft}$., 50 cts. each, $\$ 4$ for 10.

S. canadensis acutiloba. Cut-leaved Elder. A very handsome type of the foregoing, with finely cut foliage and excellent habit. Distinct. 3 to $4 \mathrm{ft}$., 75 cts. each, $\$ 6.50$ for 10 .

S. nigra aurea. Golden European Elder. (L) One of the best of the yellow foliage shrubs if grown in full sunlight. 3 to $4 \mathrm{ft}$., 75 cts. each, $\$ 6$ for 10 ; 2 to $3 \mathrm{ft}$., $60 \mathrm{cts}$. each, $\$ 5$ for 10 . 


\section{SAMBUCUS, continued}

S. racemosa. European Red Elder. A very vigorous 12 -foot shrub with large leaves, cream-yellow flowers, and scarlet berries. Showy and desirable border shrub. 4 to $5 \mathrm{ft}$., $\$ 1.25$ each, $\$ 11$ for 10 3 to $4 \mathrm{ft}$., $\$ 1$ each, $\$ 9$ for 10 .

\section{SPIR EA - Meadowsweet}

A vast and important family of extraordinarily beautiful shrubs. All have great charm of foliage and the profusion of flowers they produce is remarkable. The famous Bridal Wreath is familiar to everybody; and there are other sorts just as charming, with different seasons of bloom and unusual diversity of habit. We recommend them highly.

†Spiræa arguta. Garland Spirea. (M) The best early-flowering Spirea, producing, in May, sheets of flowers like drifts of snow across the border. Very hardy and beautifuI, and we consider it one of the best of the very early-flowering shrubs. 5 to $6 \mathrm{ft}$, 90 cts. each, $\$ 7.50$ for $10 ; 4$ to $5 \mathrm{ft}$., $75 \mathrm{cts}$. each, $\$ 6$ for $10 ; 3$ to $4 \mathrm{ft}$., $60 \mathrm{cts}$. each, \$5 for 10 .

†S. bumalda. Bumalda Spirea. (D) A very different bushy, dwarf plant, with Iarge, flat heads of rosy ink flowers in great profusion from July until frost. Especially good for low masses of subdued color. 2 to $21 / 2 \mathrm{ft}$., 75 cts. each, $\$ 6.50$ for $10 ; 18$ tc 24 in., 60 cts. each, $\$ 5$ for 10

†S. bumalda, Anthony Waterer. Antbony Waterer Spirea. (S) An improved form of S. bumalda. A very free-blooming, compact shrub, with bright crimson flowers in broad, flat heads. The foliage is often variegated with crimson, white, and yellow, especially in spring, and sometimes tinted with pink. Makes a desirable low flowering hedge. 2 to $21 / 2 \mathrm{ft}$., 60 cts. each, $\$ 5$ for $10 ; 18$ to 24 in., 50 cts. each, $\$ 4.50$ for 10 .

†S. bumalda froebeli. Froebel Spirea. (S) Similar to Anthony Waterer but grows taller and less compact bearing bright crimson flowers over a long period. An effective plant for broad low masses of subdued color. 3 to $4 \mathrm{ft}$., $75 \mathrm{cts}$. each, $\$ 6.50$ for $10 ; 2$ to $3 \mathrm{ft}$., 60 cts. each, $\$ 4.50$ for 10 .

S. fortunei. Fortune's Spirea. (S) A handsome shrub with upright branches and young leaves of fine purplish color. In June, its pretty pink flowers appear in Iarge, Ioose panicles. 3 to $4 \mathrm{ft}$., $60 \mathrm{cts}$. each, $\$ 4.50$ for 10 .

S. japonica ovalifolia. White Japanese Spirea. (D) This delightful, dwarf white-flowering shrub is of bushy, symmetrical form, suitable for hedges or borders. 2 to $3 \mathrm{ft}$., $60 \mathrm{cts}$. each, $\$ 5$ for $10 ; 18$ to 24 in., 50 cts. each, $\$ 4$ for 10 .

S. prunifolia. Bridal Wreath. (M) Graceful shrub, with frne, tiny double white flowers in great masses along the stems in May. This is a very weIl known and long popular plant, as the common name indicates. Lately there has been a tendency to apply the name Bridal Wreath to $S$. vanboutte which has become much more common. 3 to $4 \mathrm{ft}$., 75 cts. each, $\$ 6.50$ for 10.

S. reevesiana. Reeves' Spirea. (M) Noted for its dark green narrow foliage which is pale bluish green beneath, and its large pure white flowers. Similar to $S$. vanbouttei except that its leaves turn scarlet in the autumn. 3 to $4 \mathrm{ft}$., $60 \mathrm{cts}$. each, $\$ 5.50$ for 10 .

S. superba. Striped Spirea. (D) Quite dwarf, with striped, dark brown stems and pinkish white flowers through June and Julv. 2 to $3 \mathrm{ft}$., $60 \mathrm{cts}$. each, $\$ 4.50$ for 10 ; 18 to 24 in., 50 cts. each, $\$ 3.50$ for 10 .

S. thunbergi. Thunberg's Spirea. (M) Of especially graceful habit, growing about 5 feet tall, and bearing abundant small white flowers in May. Extensively used in shrub borders, because of its fine feathery foliage which turns orange and scarlet in autumn. 3 to $4 \mathrm{ft}$., $90 \mathrm{cts}$. each, $\$ 7.50$ for $10 ; 2$ to $3 \mathrm{ft}$., $75 \mathrm{cts}$. each, $\$ 6$ for 10 .

\section{SPIRÆA, continued}

S. trichocarpa. Korean Spirea. A spreading, arching shrub bearing mounded clusters of snowy flowers in the manner of Vanhoutte's but Iarger, broader, and blooms Iater. A very new variety and a welcome member of this interesting group of shrubs. 3 to $4 \mathrm{ft}$., $\$ 2$ each, $\$ 18$ for $10 ; 2$ to $3 \mathrm{ft}$., $\$ 1.50$ each, $\$ 13.50$ for 10 .

S. vanhouttei. Vanboutte's Spirea. (L) The finest of all Spireas. Its gracefully arching branches are covered in June with beautiful bunches of tiny white flowers. When out of flower its handsome bluish green foliage makes it very desirable. Unsurpassed for flowering hedges. 4 to $5 \mathrm{ft}$., $90 \mathrm{cts}$. each, $\$ 6$ for 10 ; 3 to $4 \mathrm{ft}$., 75 cts. each, $\$ 5$ for $10, \$ 33$ per $100 ; 2$ to $3 \mathrm{ft}$., 50 cts. each, $\$ 4$ for $10, \$ 30$ per 100 .

\section{STEPHANANDRA}

Stephanandra flexuosa. Cutleaf Stephanandra. (M) A beautiful Japanese shrub, closely allied to the spireas, of fountain-like habit, with graceful, spreading and drooping branches, and handsome, deeply cut foliage. In June its pure white flowers appear in panicled racemes. A valuable subject for shrubberies and rocky banks. 2 to $3 \mathrm{ft}$., $60 \mathrm{cts}$. each, $\$ 5$ for 10 .

\section{SYMPHORICARPOS}

Symphoricarpos chenaulti. A bushier variety than the common Snowberry, covered with light pink berries in summer and autumn. 3 to $4 \mathrm{ft}$., $\$ 1.25$ each, $\$ 10$ for $10 ; 2$ to $3 \mathrm{ft}$., $\$ 1$ each, $\$ 9$ for 10 .

†S. racemosus. Common Snowberry. (M) A fine, bushy shrub with very decorative leaves and slender branches which bend gracefully under a load of white, waxy berries, in autumn. The flowers are rose-pink and appear in July and August. It flourishes in partial shade. 3 to $4 \mathrm{ft}$., $75 \mathrm{cts}$. each, $\$ 6$ for $10 ; 2$ to $3 \mathrm{ft}$., 60 cts. each, $\$ 4.50$ for 10 .

†S. vulgaris. Coralberry. (M) Of more compact growth than the former. The flowers are greenish red and are followed by dark, purplish red berries in clusters. Excellent for massing on hillsides and rough places, or in partial shade. 3 to $4 \mathrm{ft}$., $60 \mathrm{cts}$. each, $\$ 4.50$ for $10 ; 2$ to $3 \mathrm{ft}$., 50 cts. each, $\$ 4$ for 10 .

\section{SYRINGA • Lilac}

Again we come upon a family of shrubs too familiar to require description; but who could describe their charm and beauty anyway? There's a nobility and a haunting aura of romance and memory about the Lilacs that make them almost enchanted things. They are a necessary part of every planting.

Syringa chinensis. Cbinese Lilac. (M) This variety grows about 12 feet high and resembles the Persian Iilacs in its Iarge, open heads of violet-blue flowers which appear in June. One of the finest. 3 to $4 \mathrm{ft}$., $\$ 1.25$ each, $\$ 11$ for $10 ; 2$ to $3 \mathrm{ft}$., $90 \mathrm{cts}$. each, $\$ 8$ for 10 .

S. josikæa. Hungarian Lilac. (L) A sturdy, vigorous shrub with tree-like growth, dark, shining leaves, and bluish purple flowers in June. It is especially valuable for its Iate bloom which prolongs the Lilac season. 4 to $5 \mathrm{ft}$., $\$ 1.50$ each, $\$ 13.50$ for $10 ; 3$ to $4 \mathrm{ft}$., $\$ 1$ each, \$9 for 10 .

S. persica. Persian Lilac. (M) One of the famous Lilacs with arching branches and very fragrant, pale purple flowers in rather loose, broad panicles, opening late in the spring. 4 to $5 \mathrm{ft}$., $\$ 1.50$ each; 3 to $4 \mathrm{ft}$., $\$ 1$ each, $\$ 9$ for $10 ; 2$ to $3 \mathrm{ft}$., $75 \mathrm{cts}$. each, $\$ 6.50$ for 10 .

S. villosa. Late Lilac. (L) A stout-branched shrub with bright green foliage like that of the white fringe tree. The flowers, which are borne in panicles, are light purple in bud, rosy white when open, and very fragrant. Valuable for Iate blooming. 3 to $4 \mathrm{ft}$., $\$ 1.25$ each, $\$ 11$ for 10 . 


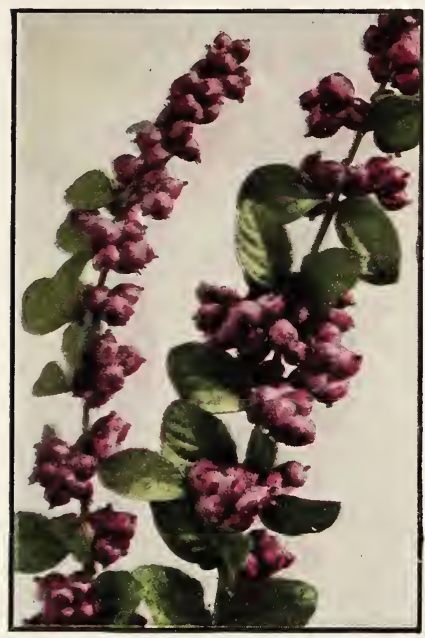

Symphoricarpos vulgaris

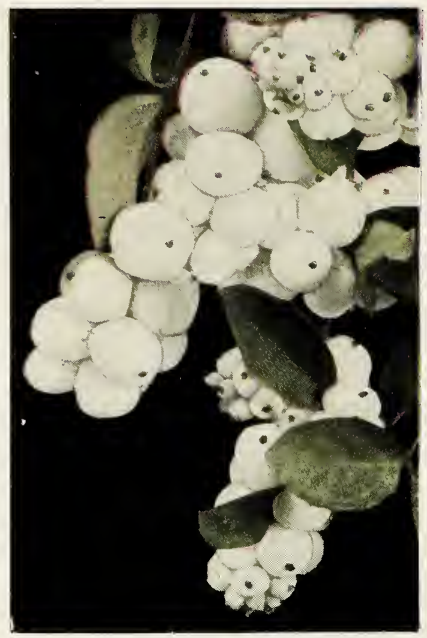

Symphoricarpos racemosus

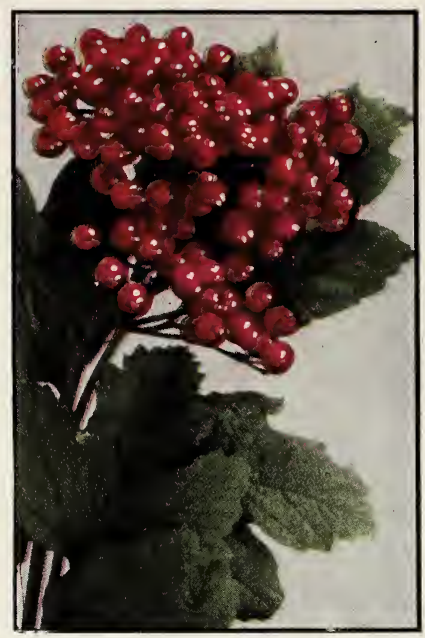

Viburnum opulus
SYRINGA, continued

†S. vulgaris. Common Lilac. (L) The best known of all Lilacs. It is a strong, vigorous, upright shrub, with rich, dark green foliage and large clusters of very fragrant purplish flowers in May. A desirable plant for a flowering hedge or large masses. 4 to $5 \mathrm{ft}$., $\$ 1.75$ each, $\$ 16$ for $10 ; 3$ to $4 \mathrm{ft}$., $\$ 1.25$ each, $\$ 11$ for $10 ; 2$ to $3 \mathrm{ft}$., $\$ 1$ each, $\$ 9$ for 10 .

†S. vulgaris alba. Common White Lilac. (L) Similar to $S$. vulgaris, with white flowers a week earlier than those of any other variety. Is also desirable for a flowering hedge or bold clump. 3 to $4 \mathrm{ft}$., $\$ 1.25 \mathrm{each}$, $\$ 11$ for $10 ; 2$ to $3 \mathrm{ft}$., $\$ 1$ each, $\$ 9$ for 10 .

\section{Hybrid Lilacs}

To those of us who were for a long time familiar with only the white and purple kinds of old dooryards, the hybrid double and improved varieties seem too splendid to be true. Unlike the old sorts, they bloom when very small plants and can be kept in fairly limited space so it is a very tiny garden indeed that cannot find room for a really representative collection of these splendid Lilacs.

Alphonse Lavallee. Double pale bluish lilac flowers. 3 to $4 \mathrm{ft}$., $\$ 2$ each; 2 to $3 \mathrm{ft}$., $\$ 1.50$ each.

Charles Joly. Double dark purplish red flowers. One of the darkest and handsomest. 2 to $3 \mathrm{ft}$., $\$ 1.50$ each; 18 to 24 in., $\$ 1.25$ each.

Charles X. Magnificent clusters of single, dark reddish purple flowers. Leaves Iarge and shining. 3 to $4 \mathrm{ft}$., $\$ 1.75$ each; 2 to $3 \mathrm{ft}$., $\$ 1.50$ each.

Claude Bernard. Large, double bright lilac-mauve flowers in full trusses. 2 to $3 \mathrm{ft}$., $\$ 1.75$ each.

Hugo Koster. Handsome pyramidal clusters of large, single, pure lilac-colored flowers. A new variety. 2 to $3 \mathrm{ft}$., $\$ 1.50$ each; 18 to 24 in., $\$ 1.25$ each.

Ludwig Spaeth. Very attractive, dark red, single flowers. One of the very brightest of the dark varieties. 3 to $4 \mathrm{ft}$., $\$ 1.75$ each; 2 to $3 \mathrm{ft}$., $\$ 1.50$ each.

Marie Legraye. A very fine single-flowering white Lilac, perhaps the most popular of its color. 3 to $4 \mathrm{ft}$., $\$ 2$ each; 2 to $3 \mathrm{ft}$., \$1.50 each.

Mme. Casimir Perier. Double, cream-white flowers. 3 to $4 \mathrm{ft}$., \$1.75 each; 2 to $3 \mathrm{ft}$., \$1.50 each.

Mme. Lemoine. Large, double, white flowers in immense clusters. 3 to $4 \mathrm{ft}$., $\$ 1.75$ each; 2 to $3 \mathrm{ft}$., S1.25 each.
HYBRID LILACS, continued

Mrs. Edward Harding. Giant, full trusses of Iarge, double bright carmine flowers. 2 to $3 \mathrm{ft}$., $\$ 5$ each.

Pascal. Single, pure lilac-colored flowers, borne in great profusion. 2 to $3 \mathrm{ft}$., $\$ 1.50$ each.

President Grevy. Fine double variety, with Iarge panicles of beautiful pale blue flowers. 3 to $4 \mathrm{ft}$., $\$ 1.75$ each; 2 to $3 \mathrm{ft}$., $\$ 1.50$ each.

Red Marly. Flowers single, rich rosy purple. An exceedingly free bloomer. 3 to $4 \mathrm{ft}$., $\$ 2$ each; 2 to $3 \mathrm{ft}$., $\$ 1.50$ each.

Vestale. Giant trusses of single, pure white, hyacinthlike flowers of perfect shape. Very beautiful. 2 to $3 \mathrm{ft}$., $\$ 1.50$ each; 18 to 24 in., $\$ 1.25$ each.

\section{Standard Hybrid Lilacs Tree Form}

4 to $5 \mathrm{ft}$., $\$ 3$ each, except as noted

Charles X. Single; dark reddish purple.

Hugo Koster. Single; pure lilac.

Jan Van Tol. Single; pure white; choice variety. $\$ 3.50$ each.

Ludwig Spaeth. Single; dark red.

Marie Legraye. Single; white.

Michel Buchner. Double, pale Iilac.

Mme. Lemoine. Double; white.

President Grevy. Double; pale blue.

\section{TAMARIX • Tamarix}

Tamarix africana. African Tamarix. (L) An ornamental shrub of graceful appearance, with light, feathery foliage and long, slender racemes of pinkish flowers in early summer. Forms a striking picture planted at the edge of an evergreen border. 3 to $4 \mathrm{ft}$., 60 cts. each, $\$ 5$ for 10 .

\section{VACCINIUM - Blueberry}

†Vaccinium corymbosum. Higbbush Blueberry. A handsome shrub 4 to 12 feet high, much valued for its large, blue-black berries of excellent flavor but favored perhaps even more for its brilliant colored fall foliage which gives a distinct naturalistic effect. The plants we offer are stocky. 3 to $4 \mathrm{ft}$., $\$ 2$ each, $\$ 18$ for $10 ; 2$ to $3 \mathrm{ft}$., $\$ 1.25$ each $\$ 11$ for 10 . 


\section{VIBURNUM}

Here is a group of tremendously important shrubs embracing great variety, from the old-time beauty of the Snowball to the fascinating delicacy of the lace-like Viburnum tomentosum, which some think has the Ioveliest flower of any shrub or tree. Most of them are prolific bloomers, do well in semi-shade, and follow their flowers with a profusion of handsome fruits of varying colors. This is a group that no one interested in shrubs, and especially native shrubs, can afford to overlook.

Viburnum acerifolium. Mapleleaf Viburnum. A good shrub for dry soil under trees. Flowers yellowish; foliage interesting and maple-like; fruits blackish. This is the Dockmackie of northeastern North America whose foliage is so handsome in late autumn. 2 to $3 \mathrm{ft}$., $\$ 1$ each, $\$ 9$ for 10 .

V. americanum. American Cranbern Busb. This very decorative native shrub is of open habit, with attractive flowers and bunches of berries which begin to turn red in July, remaining on the plant until the following spring. 3 to $4 \mathrm{ft}$., $\$ 1$ each, $\$ 8.50$ for 10 ; 2 to $3 \mathrm{ft}$., 75 cts. each, $\$ 6.50$ for 10 .

V. carlesi. Fragrant Viburnum. A low, round bush of rather stubby growth which, in spring, bears charming clusters of pale rosy white flowers of the most delicious fragrance. Rare and much prized. $21 / 2$ to $3 \mathrm{ft}$., $\$ 5$ each; 2 to $21 / 2 \mathrm{ft}$., $\$ 4$ each; 18 to 24 in., \$3 each, \$27 for $10 ; 12$ to 18 in., \$2 each, \$18 for 10 .

$\dagger$ V. cassinoides. Witbe-rod. (M) Slender, uprightgrowing, well furnished with dull green foliage. It has creamy white flowers in June, followed by clusters of dark blue fruit in autumn. Fine for waterside planting or shrub borders, and makes a desirable tall narrow hedge. 4 to $5 \mathrm{ft}$., $\$ 2 \mathrm{each}$, $\$ 18$ for $10 ; 3$ to $4 \mathrm{ft}$., $\$ 1.25$ each, $\$ 10$ for $10 ; 2$ to $3 \mathrm{ft}$., 90 cts. each, $\$ 7.50$ for 10 .

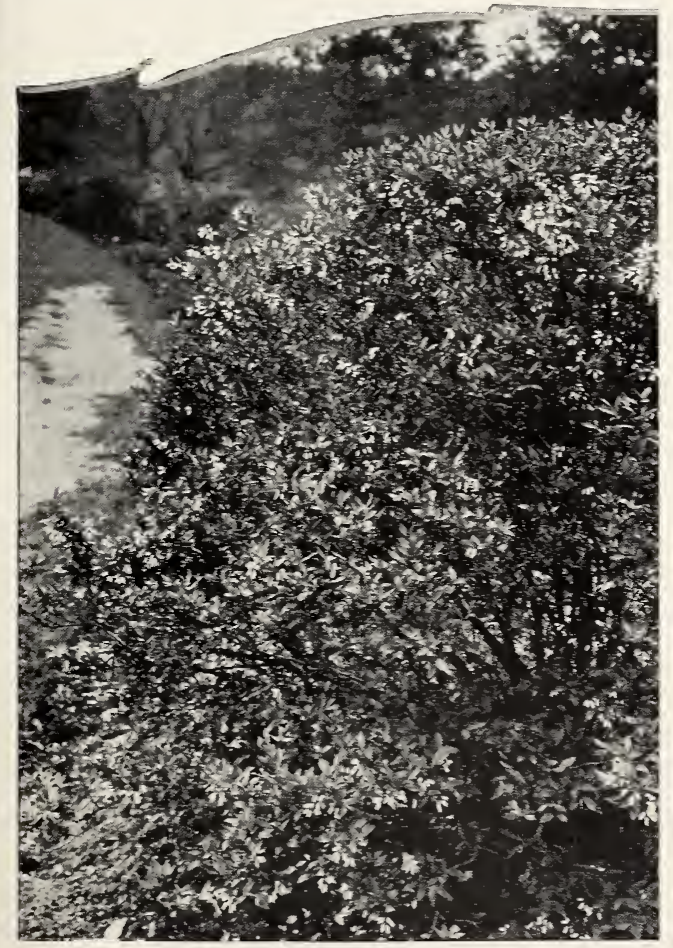

Vaccinium corymbosum

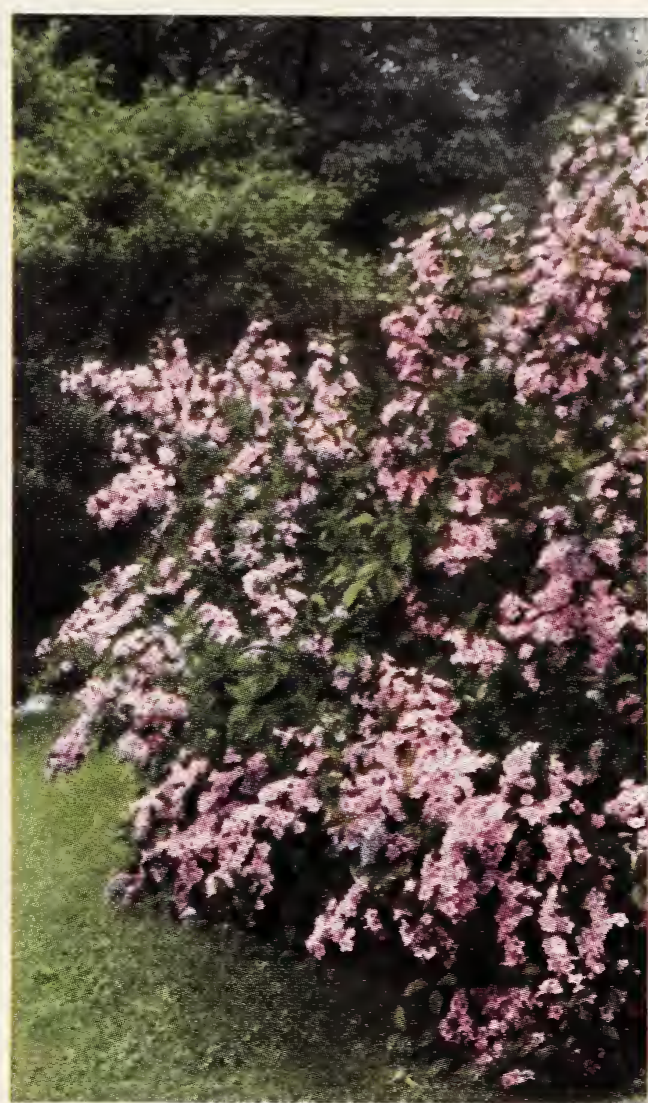

Weigela rosea. See page 38

†V. dentatum. Arrow-uood. (L) A very handsome, native shrub with glossy green foliage, and white flowers in June, followed by crimson berries which turn blue in autumn. Like the other Viburnums, this variety will flourish in partial shade and likes a moist soil. 4 to $5 \mathrm{ft}$., $\$ 1.25 \mathrm{each}, \$ 10$ for $10 ; 3$ to $4 \mathrm{ft}$., 90 cts. each, $\$ 7.50$ for $10 ; 2$ to $3 \mathrm{ft}$., 75 cts. each, $\$ 6$ for 10.

V. lantana. Wavfaring Tree. (L) Of robust growth, having large foliage which is silvery underneath. It produces clusters of white flowers in May followed by red fruit, turning black in autumn. Especially good on dry, limestone soils. 3 to $4 \mathrm{ft}$., $\$ 1$ each, $\$ 8$ for $10 ; 2$ to $3 \mathrm{ft} ., 75 \mathrm{cts}$. each, $\$ 6$ for 10

$\dagger$ V. lentago. Nanniberr. (L) A vigorous shirub which may become a small tree. It has creamy white, very fragrant flowers, light glossy green foliage, and bluish black fruit. 5 to $6 \mathrm{ft}$., $\$ 1.25$ each, $\$ 10$ for $10 ; 4$ to $5 \mathrm{ft}$., $\$ 1$ each, $\$ 8$ for $10 ; 3$ to $4 \mathrm{ft}$., 75 cts. each, $\$ 6.50$ for 10 .

V. molle. Kentucky Viburnum. (M) While this is a native shrub, it is quite rare and is seldom seen. It resembles $V$. dentatum, but has broader, darker foliage, larger fruits, and is a splendid novelty in the shrub border. 4 to $5 \mathrm{ft}$., $\$ 1$ each, $\$ 9$ for $10 ; 3$ to $4 \mathrm{ft}$., 75 cts. each, $\$ 6.50$ for 10 .

†V. opulus. European Cranberr Busb. (L) One of the best shrubs for general planting. It has white flowers in panicles and red berries, resembling cranberries, which remain until early winter. The foliage is large and healthy, seldom attacked by insects. 3 to $4 \mathrm{ft}$., $\$ 1$ each, $\$ 9$ for $10 ; 2$ to $3 \mathrm{ft}$., 75 cts. each, $\$ 6.50$ for 10 .

V. opulus nanum. Dwarf Cranberr Busb. A dwarf variety of the foregoing, compact and small-leaved. It rarely flowers. 12 to 18 in., 90 cts. each, $\$ 8$ for 10 


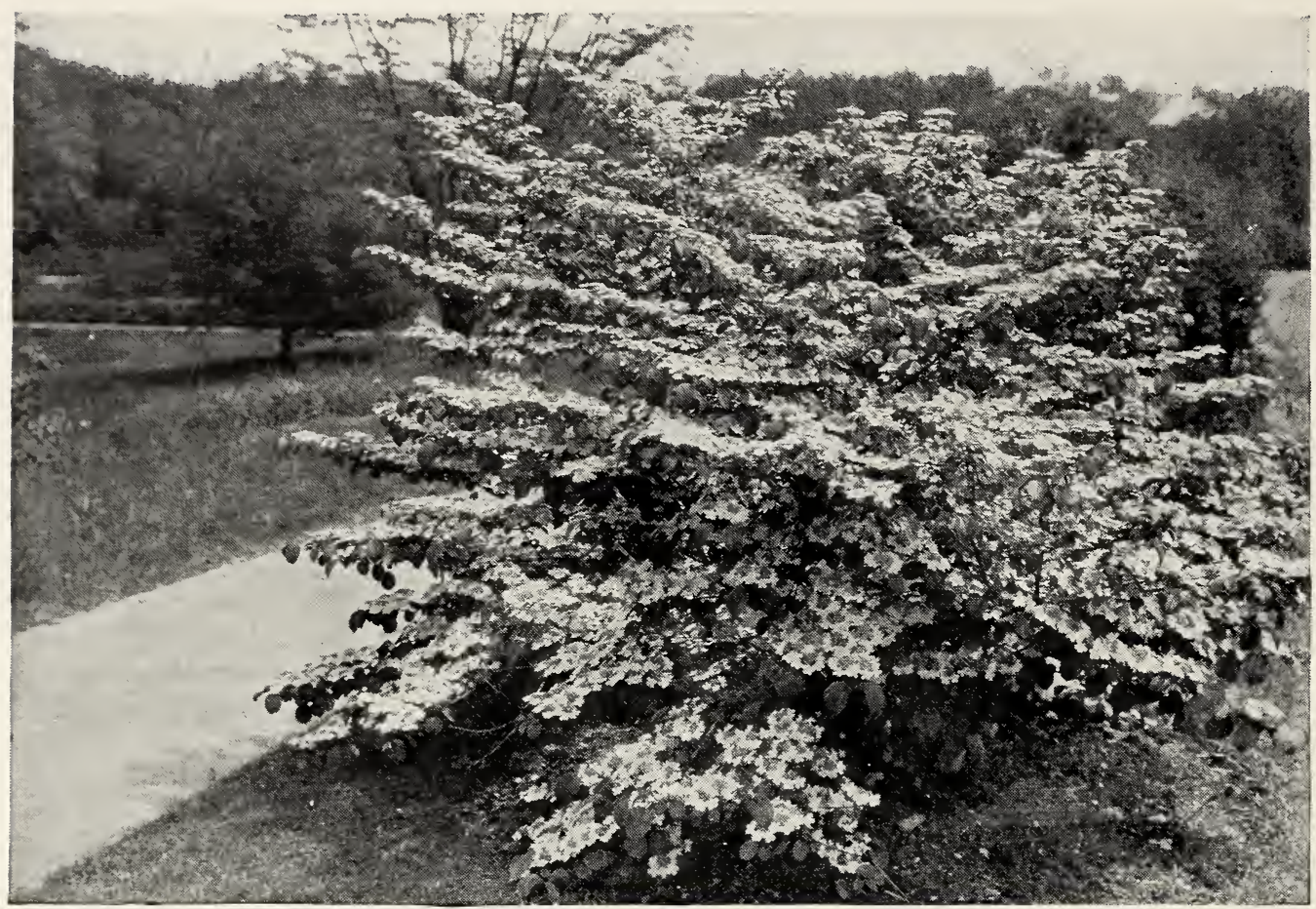

Viburnum tomentosum. Double-file Viburnum. Words cannot do its beauty justice-it must be seen.

VIBURNUM, continued

V. opulus sterile. Common Snowball. (L) A wellknown, large shrub, producing large, snowballlike flowers in May. 4 tc $5 \mathrm{ft}$., $\$ 1.25$ each, $\$ 10$ for 10 ; 3 to $4 \mathrm{ft}$., very heavy, $\$ 1$ each, $\$ 8.50$ for 10 .

V. sieboldi. Siebold's Viburnum. (M) This vigorous-growing plant has unusually large, rich green foliage, and white flcwers in clusters. 3 to $4 \mathrm{ft}$., $\$ 1.25$ each; 2 to $3 \mathrm{ft}$., \$1 each, \$9 for 10 .

V. tomentosum. Double-file Viburnum. (M) Foliage resembles the Japanese Snowball, and the flowers are white, in flat racemes, and borne in great profusion, followed by red berries changing to bluish black. Beyond question the most beautiful of all Viburnums, and possibly of all shrubs. 3 to $4 \mathrm{ft}$., $\$ 1.25$ each, $\$ 11$ for $10 ; 2$ to $3 \mathrm{ft}$., $\$ 1$ each, $\$ 8$ for 10 .

V. tomentosum plicatum. Japanese Snowball. (M) It has handsome leaves and globular heads of pure white flowers in June. Better than the Common Snowball in foliage and flower. 3 to $4 \mathrm{ft}$., $\$ 1.2 .5$ each, $\$ 11$ for $10 ; 2$ to $3 \mathrm{ft}$., $\$ 1$ each, $\$ 8$ for 10 .

\section{WEIGELA}

The flowers of the Weigelas have a certain resemblance to those of the wild azaleas and, like them, have been confused with honeysuckles. These pretty shrubs bloom for a Iong time and in reckless profusion. They are valuable for hardluck situations, and furnish generous variety to any shrub border.

Weigela floribunda. Crimson Weigela. A rather wellknown and popular leafy shrub with an abundance of tubular crimson flowers. 3 to $4 \mathrm{ft}$., 75 cts. each, \$6 for $10 ; 2$ to $3 \mathrm{ft}$., $60 \mathrm{cts}$. each, $\$ 5.50$ for 10 .

W. rosea. Pink Weigela. A verv free-flowering shrub somewhat similar to the preceding with bright pink flowers which are considerably larger. 3 to $4 \mathrm{ft}$. 60 cts. each, $\$ 5$ for $10 ; 18$ to 24 in., 50 cts. each, $\$ 3.50$ for 10 .

\section{WEIGELA, continued}

W. rosea nana variegata. Variegated Weigela. A dwarfish sort with white-margined leaves and almost pure white flowers. 2 to $3 \mathrm{ft}$., 75 cts. each, $\$ 6$ for 10 ; 18 to 24 in., 60 cts. each, $\$ 4.50$ for 10 .

\section{Hybrid Varieties of Weigela}

Candida. Snow Weigela. A fine white variety with unusually large and attractive flowers. Very pretty for cutting. 3 to $4 \mathrm{ft}$., $60 \mathrm{cts}$. each, $\$ 5$ for 10 .

Eva Rathke. Perhaps the most showy of all, with dark brownish red flowers, brightened by a light center. Very profusely flowering. A well-known variety that has been popular for a long time. 3 to $4 \mathrm{ft}$., 90 cts. each, $\$ 7.50$ for $10 ; 2$ to $3 \mathrm{ft}$., 75 cts. each, $\$ 6.50$ for 10.

Hendersoni. Henderson Weigela. A handsome variety with bright, light crimson flowers. Very attractive. 3 to $4 \mathrm{ft}$., $60 \mathrm{cts}$. each, $\$ 5.50$ for $10 ; 2$ to $3 \mathrm{ft}$., $50 \mathrm{cts}$. each, $\$ 4.50$ for 10 .

\section{ZANTHORHIZA}

Zanthorhiza apiifolia. Yellow-Root. (D) Native shrub of low, slender growth, bearing cloudy sprays of plum-colored flowers, like tiny black stars, in April. Valuable for its foliage and dwarf habit, and much used for ground-cover. Very hardy and desirable. In autumn the foliage is gorgeous golden yellow. 15 to 18 in., 50 cts. each, $\$ 4.50$ for 10 ; 12 to 15 in., 40 cts. each, $\$ 3.60$ for 10 .

\section{ZENOBIA}

Zenobia pulverulenta. Dusty Zenobia. An arching shrub with oval leaves covered with a dusty bloom and clusters of tiny white flowers like lilies-of-thevalley. This very showy and handsome plant is distinctly unusual, and should have a place in every planting of any size. 2 to $3 \mathrm{ft}$., $\$ 1.50$ each. 


\section{HEDGE PLANTS}

25 or more of one size at the 100 rate

BARBERRY, Japanese (Berberis tbunbergi). One of the most popular hedge plants. Thorny, dense, man-, dog-, and boy-proof. May be left unsheared or clipped to an even, rounded form. Pretty clusters of red berries in autumn and winter.

$\begin{array}{rlrrr}2 \text { to } 21 / 2 \text { ft., bushy plants...... } \$ 4 & 00 & \$ 27 & 00 \\ 18 \text { to } 24 \text { in., bushy plants....... } & 2 & 50 & 18 & 00 \\ 15 \text { to } 18 \text { in., bushy plants....... } & 2 & 00 & 12 & 00 \\ 12 \text { to } 15 \text { in., bushy plants....... } & 1 & 50 & 9 & 00\end{array}$

PRIVET, Amur (Ligustrum amurense). Erect, dense hedge of dark, lustrous green. Can be trimmed to any form and is very quick-growing and hardy.

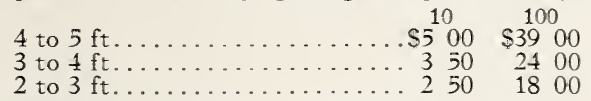

California (L. ovalifolium). Used in great quantity everywhere, and the most commonly used hedge plant in America. The dark, shining green foliage is almost evergreen, and the hedge can be trimmed to any size, height, or shape. Our plants have stocky tops and heavy roots.

$10 \quad 100$

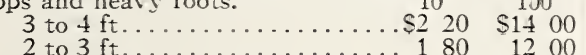

18 to 24 in.................. $150 \quad 1000$

Ibolium (L. ibolium). A vigorous, swiftly growing hybrid between the California Privet and the Ibota Privet, combining the beautiful foliage of the former with the greater hardiness of the latter.

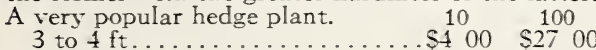

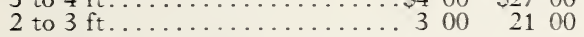

Privet, Ibota ( $L$. ibota). Tall, woody growth, with relatively large leaves and arching branches. Very hardy and quick-growing. 10100 3 to $4 \mathrm{ft} \ldots \ldots \ldots \ldots \ldots \ldots \ldots \ldots+50 \ldots \ldots 2700$

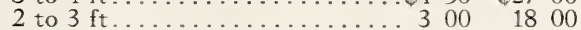

Regel (L. ibota regelianum). Low, horizontally branching, which requires little or no trimming to make a perfect hedge. Very hardy. $\$ 10 \quad$\begin{tabular}{ll}
100 \\
\hline 3
\end{tabular} 18 to $21 / 2 \mathrm{ft} \ldots \ldots \ldots \ldots \ldots \ldots . \$ 3500 \quad \$ 3900$

ROSE, F. J. Grootendorst. A fine shrub with handsome foliage and clusters of small, bright crimson flowers all summer. Excellent at summer places along the sea, where an abundance of flowers from July to October is wanted. Perfectly hardy. Plant 1 foot apart. 2-vr., \$1 each, \$9 for 10,\$80 per 100.

Pink Grootendorst. Like F. J. Grootendorst, except that the flowers are pretty shell-pink. 2 -rr., \$1 each, \$9 for 10, \$80 per 100.

Rugosa (Rosa rugosa). Vigorous and erect, with big, handsome foliage and large, rosy purple flowers all summer, followed by showy red and vellow fruits. It makes one of the best hedges near the seashore, withstanding much exposure and $\begin{array}{lll}\text { salt-spray. } & 100 & 100 \\ 2 & 3 & \end{array}$ 18 to 24 in...................... $450 \quad 3300$

WILLOW, Laurel (Salix pentandra). Quick-growing, slender, small trees with handsome foliage, especially useful for tall screens to hid objectionable views or objects.

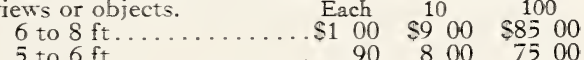
4 to $5 \mathrm{ft}$

\section{A List of Particularly Interesting Items}

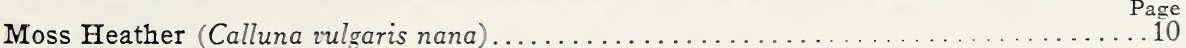

European White Birch (Betula alba)..................................... 16

Red Maple (Acer rubrum) ............................................. 15

Carolina Rhododendron (Rbododendron carolinianum) . . . . . . . . . . . . . . . . 13

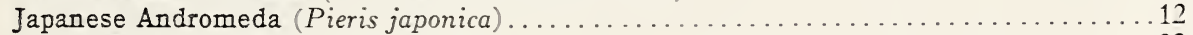

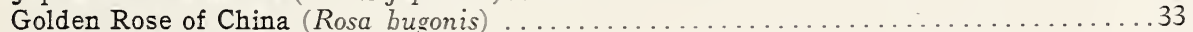

Vernal Witch-Hazel (Hamamelis vernalis) . . . . . . . . . . . . . . . . . . . . . . . 28

Yeddo Euonymus (Euonymus yedoensis) . ..............................

White Fringe Tree (Cbionantbus virginica) . . . . . . . . . . . . . . . . . . . 17

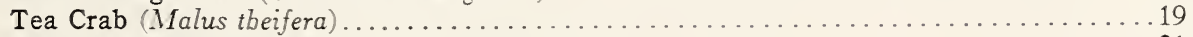

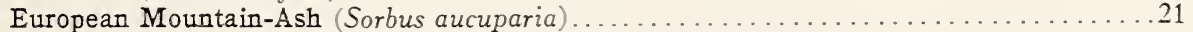

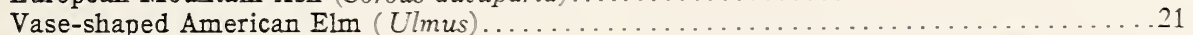

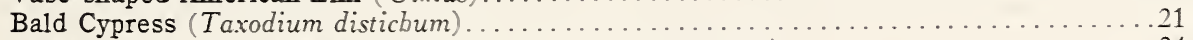

Red-leaved Japan Barberry (Berberis tbunbergi atropurpurea) ................... 24

European Burning Bush (Euonymus europæus) . . . . . . . . . . . . . . . . . . . . . 27

Common Witch-Hazel (Hamamelis rirginiana) . . . . . . . . . . . . . . . . . . 28

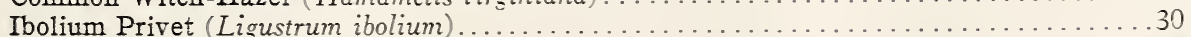

Scotch Rose (Rosa spinosissima) ...................................... 34

Fragrant Viburnum (Viburnum carlesi) . . . . . . . . . . . . . . . . . . . . . . 37

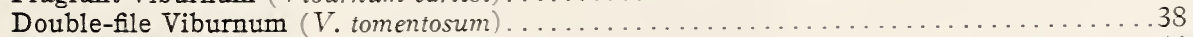

Porcelain Ampelopsis (Ampelopsis beteropby-lla) .........................4

Chinese Fleece Vine (Polv'gonum auberti) . . . . . . . . . . . . . . . . . . . . . 45

Rose, F. J. Grootendorst . . . . . . . . . . . . . . . . . . . . . . . . . 42

Columnar Chinese Juniper (Juniperus cbinensis columnaris) ................... 3

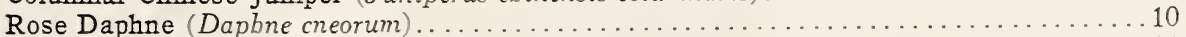

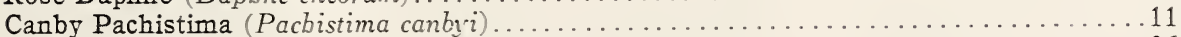

Rock Cotoneaster (Cotoneaster borizontalis) ................................ 26

Baby Wintercreeper (Euon mus radicans minimus) .......................... 11 


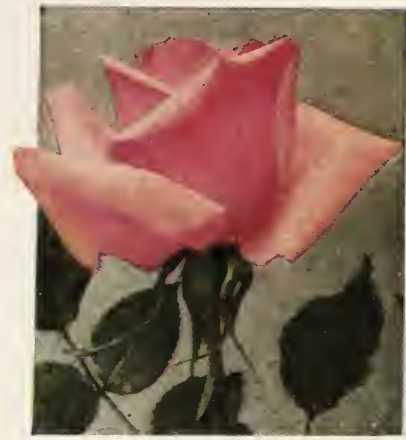

Betty Uprichard

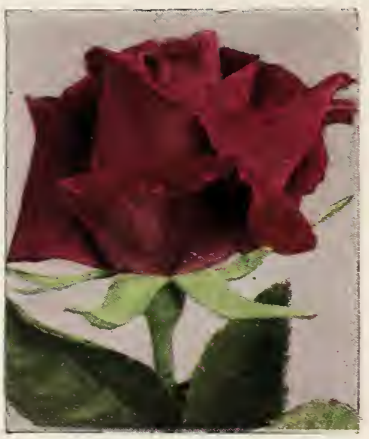

Etoile de Hollande

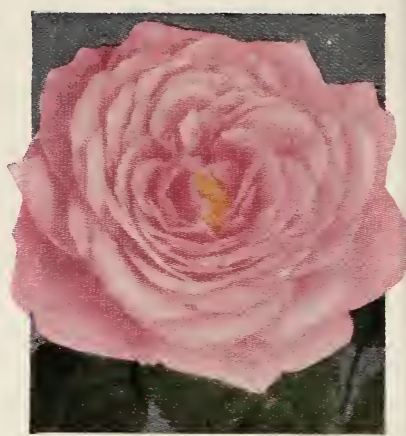

Lady Alice Stanley

\section{ROSES}

$\mathrm{N}^{\circ}$ ONE needs an introduction to Roses. Everybody who has a few square feet of ground would like to have them-and can have them. We have chosen varieties carefully to insure a good start. The soil should be prepared as for a good crop of vegetables, and be kept thoroughly cultivated about the Roses aII season. They should be fed liberally with liquid manure made from fresh cow manure or from the commercial dried sheep manure, and should be dusted with sulphur and arsenate of lead regularly to keep off pests. Cut the flowers freely with long stems and hill up the plants with earth at the approach of winter, covering the tops with leaves or evergreen boughs when the ground is frozen.

These simple methods will insure a bountiful crop of supreme flowers, and we urge all our friends to give Roses a chance to show what they can do.

A special illustrated leaflet telling "How Roses Should Be Planted" will be sent on request and a copy will be enclosed with each shipment of Roses

\section{HYBRID TEAS}

These are the dwarf everblooming Roses which produce the beautifuI, Iong-stemmed flowers everyone so much admires. They should be planted about 15 inches apart in rather narrow beds and in lots of not less than three, and preferably a half-dozen or more, of one kind.

Our Hybrid Teas are 2-year-old, field-grown, budded plants, thoroughly dormant for early spring planting. Price $\$ 1$ each; 5 or more of one kind, $90 \mathrm{cts}$. each, except as noted. We will furnish 10 or more in varieties of our own selection at $90 \mathrm{cts}$. each.

Betty Uprichard. One of the most vigorous and dependable decorative bedding Roses. Flowers semidouble, brilliant copper and salmon, very freely produced. Unusually good.

Columbia. Beautifully formed flowers of firm texture, with stiff, curled petals, opening pink, darkening to glowing rose as they age. Stems long and strong and almost thornless.

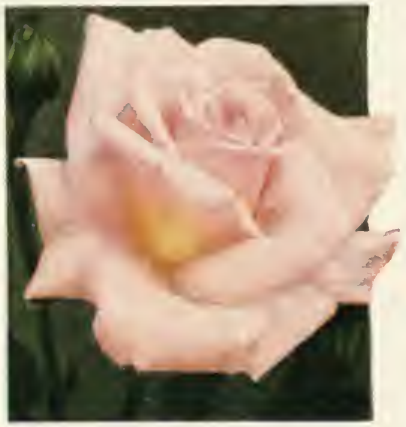

Mme. Butterfly

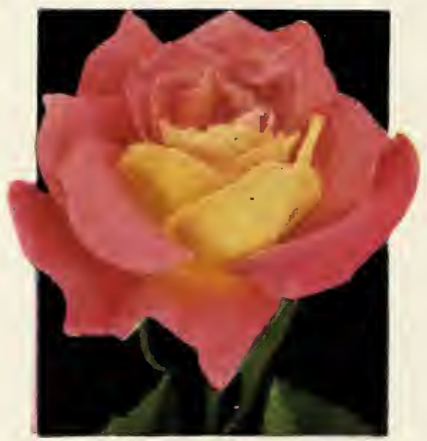

Talisman

\section{HYBRID TEA ROSES, continued}

Dame Edith Helen. Very large, beautifully shaped, extremely double flowers of pure, light pink; very fragrant, and long lasting. Regarded as the handsomest of the very new varieties. \$1.50 each.

Duchess of Wellington. Particularly admired for its gigantic, long, richly tinted buds of apricot and yellow. The flowers are very large, not fully double when open, and much lighter in color.

Edel. A noble, perfectly shaped, white Rose of great size and substance. Very handsome, both as a bud and open flower.

Etoile de Hollande. Glowing scarlet-crimson, fragrant, and free-flowering. Generally considered the best dark red bedding Rose for the amateur's garden. $\$ 1.50$ each.

General MacArthur. Long known as the best red Rose for the garden. Bright, pure color, and one of the most floriferous.

Golden Ophelia. A dark yellow variation of the popular Ophelia.

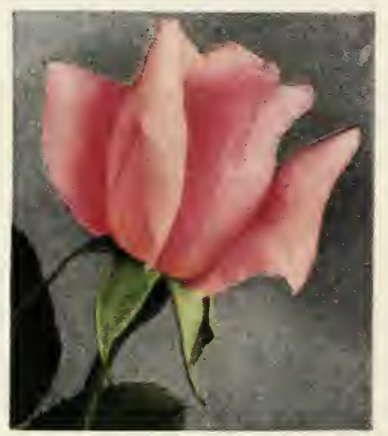

Willowmere 


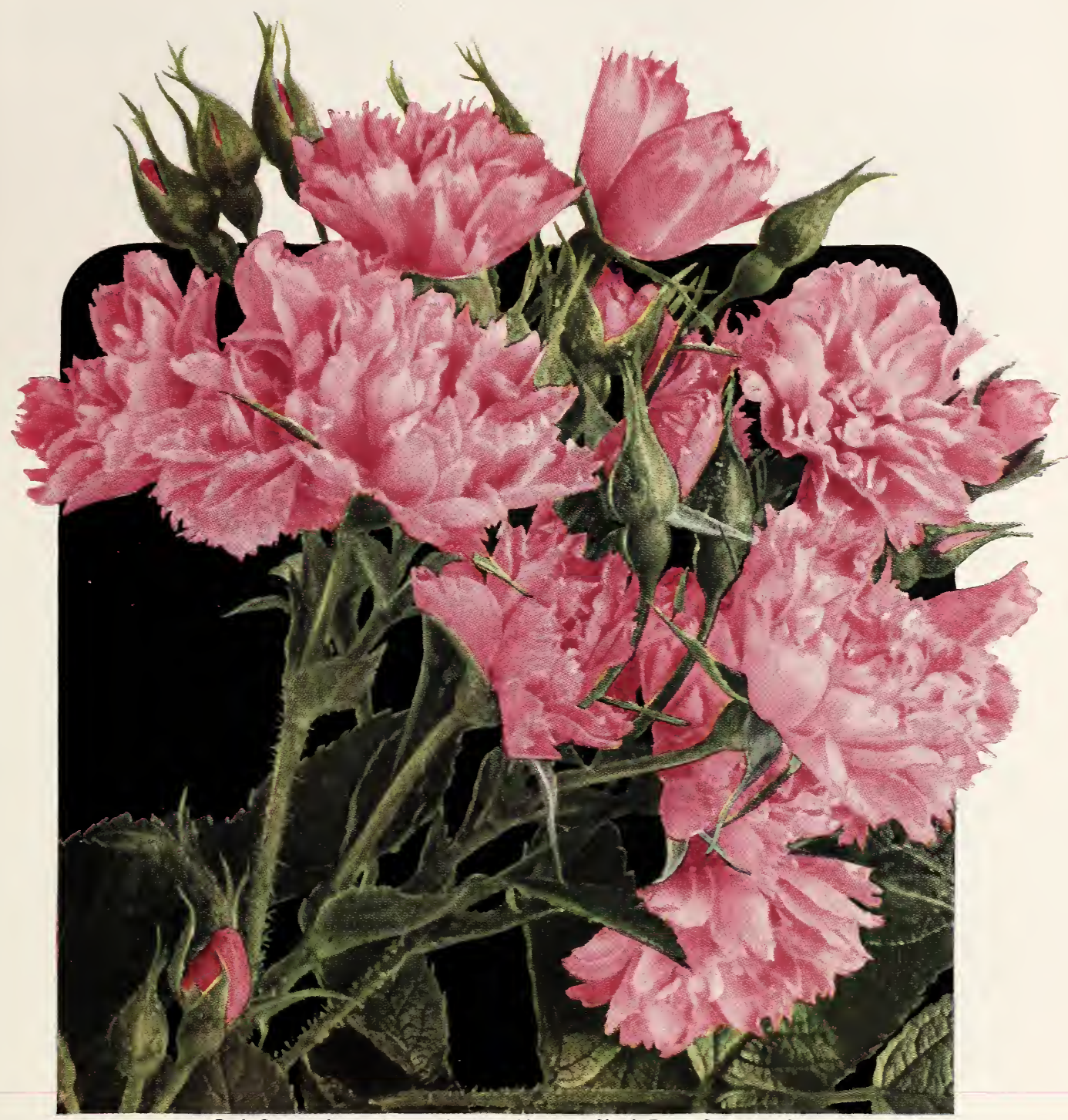

Pink Grootendorst. A marvelous everblooming Shrub Rose. See page 42

\section{HYBRID TEA ROSES, continued}

Gruss an Teplitz. This is different from other Hybrid Teas in its tall, bushy growth, and rather small, nodding flowers in clusters. It is, beyond question, the best outdoor decorative red Rose in existence, but should be planted in masses by itself or in a border around the Hybrid Tea garden proper.

Independence Day. A brilliant orange-yellow Rose with striking flame-color tints, borne very freely on low, branching plants which look best in big masses. The buds are almost unbeatable, but the open flowers are not as double as some.

Kaiserin Auguste Viktoria. This has Iong been known as the most beautiful white Rose in the world. The bush does not grow very strong, but it is worth having for its unsurpassed beauty of form and color

Killarney Queen. The Killarney Roses have always been popular and this is the best of the bright pink ones. The buds are splendid.

Killarney White. Typical of the Killarney type, but the big-petaled blooms are snowy white. A very fine white Rose.

Lady Alice Stanley. One of the most handsome and easily grown of the very fine pink Roses. A general favorite with beginner and expert alike.
Lady Margaret Stewart. Large, deep buds and blooms of golden yellow and apricot, flamed with bronze and scarlet. Growth and foliage vigorous and healthy. \$2 each.

Los Angeles. A flame-pink Rose of unusual beauty and delicious fragrance. The plants are not always reliable, but they are decidedly worth growing for the extraordinary beauty of the flower.

Miss Willmott. Very large flowers of glistening white, daintily tipped with fawn and pink. Without doubt the best white Rose for the garden. It has better flowers than Mme. Jules Bouché and is not so embarrassingly vigorous as Frau Karl Druschki.

Mme. Albert Barbier. Large, round, perfectly double flowers of pale peach-pink and yellow. A dwarf, stocky. grower, holding the fiowers stiffly erect. Very charming and popular.

Mme. Butterfly. An exquisite Rose of firm texture and perfect form, shaded with pale-pink, cream, and gold. It is universally acclaimed as a close approach to the ideal garden Rose.

Mme. Edouard Herriot. The blazing copper-red bloom is of almost violent intensity, paling as it opens to soft shrimp-pink. One of the finest Roses. 


\section{HYBRID TEA ROSES, continued}

Mrs. Aaron Ward. This is a charming little Rose of unusual form, opening rich, golden fawn, paling as it ages to cream, very pale pink, and white. The low, spreading bush has splendid foliage.

Mrs. William C. Egan. Exquisite, Iong-pointed buds of delicate rosy white and pale pink. The flowers are very large and star-like. A strong grower and free flowering. Very fine.

Ophelia. Very similar to Mme. Butterfly, but a shade or two lighter. We like to call it pearly white, because of the beautiful iridescent shades of faint pink, gold, and lilac which play over its waxen petals.

Padre. Brilliant copper-red, almost single flowers, borne on tal!, slender stems. Plant the bushes closely together in masses. It makes a stunning show.

Radiance. This is generally considered the best allround Rose for the beginner. The plants are very strong and they bloom with the greatest freedom producing big, round flowers of sparkling pink al summer and fall.

Red Radiance. Very much like Radiance in every respect, except that the flowers are bright, light red instead of pink. Some say it grows even better.

Rev. F. Page-Roberts. Large, golden yellow flowers stained red and copper on the buds and outside of the petals; very fragrant. One of the most beautiful Rose known. \$1.50 each.

Souvenir de Claudius Pernet. This is the best pure yellow Rose for the garden. The plants grow stiffly erect, with shining leaves, and bright, unfading yellow flowers. They are best in the bud and before they are fully open.

Talisman. A gorgeous novelty of 1929. Golden yellow buds and flowers splashed and shaded with vivid scarlet-crimson. Blooms continuously and the plant is both vigorous and healthy. Rare and very fine. $\$ 2$ each, \$18 for 10 .

Ville de Paris. Large, globular flowers of pure yellow which do not fade lighter. The plants are tall and wiry and bloom profusely. Foliage leathery and very resistant to disease. A handsome and well-liked new variety.

Wilhelm Kordes. Very showy; salmon and flaming orange shades mingle in the lovely, firm, curled petals. Best in cooler weather but very changeable and lovely at all times. $\$ 1.50$ each.

William R. Smith. A low, wide-spreading bush bearing large, beautifully pointed white flowers delicately tinted with pale pink and cream. Very fine.

Willowmere. Soft, golden pink, with Iuminous lights all through its shell-like petals. The buds are very large, exquisitely curled, and the open flowers are magnificent. The bush is very strong and blooms twice as much as most Roses.

\section{HYBRID RUGOSA ROSES}

Our Hybrid Rugosa Roses are $\$ 1$ each, or 5 or more of one kind at $90 \mathrm{cts}$. each, except as noted

Blanc Double de Coubert. An excellent, vigorous variety with pure white, semi-double, fragrant flowers.

Conrad Ferdinand Meyer. Very strong, sturdy growth, often reaching 10 to 12 feet. Flowers large, very beautifully formed, and clear light silvery pink.

F. J. Grootendorst. A perfectly hardy everblooming shrub Rose suitable for hedges, specimens or border planting. The plant is similar to the vigorous Rugosas in growth, with large, glossy foliage which is seldom attacked by insects or disease. The flower are small, bright red, fringed like little carnations, and are borne unceasingly from early summer until late autumn in large clusters. We consider it one of the most valuable introductions of recent years.

Pink Grootendorst. A charming, bright shellpink variation of the scarlet F. J. Grootendorst, like it in all other respects and equally valuable. We find it very popular with those who do not care for the hard brilliance of the red variety and believe it is really a more attractive plant. The color is very soft and appealing and makes a charming effect in the mass. See illustration in color on page 41 .

Sarah Van Fleet. A boId, handsome plant of very vigorous growth, with large, semi-double, intensely fragrant flowers of pure pink-the clearest shade of this color in the family. $\$ 1.50$ each.

\section{POLYANTHAS}

The name means "many-flowered." They bear small flowers in big clusters steadily throughout the summer and make dwarf bushy plants suitable for edging beds of Hybrid Perpetuals, paths, fountains, pools, or shrubbery borders. Undoubtedly the most continuous blooming type of Roses.

\section{Our Polyantha Roses are $\$ 1$ each, or 5 or more of one} kind at $90 \mathrm{cts}$. each

Baby Rambler. Its big clusters of light, purplish crimson flowers are borne in the greatest profusion throughout the summer. Very good.

Chatillon Rose. Brilliant pink, semi-double flowers in giant clusters very freely produced. This variety has a liveliness of color and a persistency in blooming unsurpassed by any other sort.

Ideal. The best dark red Polyantha. Flowers are in large clusters, freely produced. Dwarfer than most.

Katharina Zeimet. Wbite Baby Rambler. Tiny, very double, snowy white, button-like flowers in tremendous clusters.

La Marne. A very beautiful single variety with great clusters of soft pink flowers with lighter edges and golden centers. Excellent for edging and dwarf hedges.

\section{HYBRID PERPETUALS}

These Roses are bigger, stronger, and hardier than the Hybrid Teas. 'They are essentially coldcountry Roses, and delight in cool weather in spring and summer. Their magnificent blooms are produced in early summer and again in late faII, surpassing all other Roses in brilliance of color and in fragrance.

Feed them heavily and protect them somewhat from the most severe winters.

\section{All Hybrid Perpetual Roses are $\$ 1$ each, or 5 or more} of one kind at $90 \mathrm{cts}$. each

Fraul Karl Druschki. The best white Rose for the garden. Buds are pinkish, but the delightfully shaped flowers are pure, snowy white. The plant grows very large and blooms continuously like a Hybrid Tea. Its flowers have no scent.

General Jacqueminot. This is the old-fashioned, rich, sparkling red Rose of fragrant memory. It is still one of the best red varieties, and should be in every garden.

Harison's Yellow. This is not a Hybrid Perpetual, but a big, bushy, briar Rose, common in old-time gardens, where it blooms in great billows of bright yellow very early in the season. Undoubtedly the finest hardy yellow Rose there is, and it should be freely planted for specimens, borders, and hedges.

Mrs. John Laing. Very symmetrical, smooth flowers of soft, glowing pink, deliciously sweet. It blooms very dependably from early summer until late fall and is always one of the loveliest things in the garden.

Paul Neyron. A big, handsome flower of light purplish pink, sweetly fragrant, and very persistent in blooming. This is the Rose most people mean when they say American Beauty.

Ulrich Brunner. Bright, sparkling crimson flowers of cup-like form, and richly fragrant. The bush is particularly strong and blooms most profusely in early summer. 


\section{CLIMBING ROSES}

Perhaps there is no one group of plants that is so useful and so beautiful in so many different ways as the Climbing Roses. They are suitable for all uses to which most climbers may be put, and surpass almost all of them in the massed splendor of their flowers. They are delightful when trained over a stone wall or grouped to form a hedge-fence, when trained upon a rustic arbor, over a perola, at the corners of a porch, or over a trellis about the windows of the house. They may adorn garden arches, gateways, fence-corners, or they may be tied to sim posts as pillars where they will make splendid spires of beauty throughout the garden. The range of color is almost limitless, and the flowers vary from tiny clustered rosettes to big blooms for cutting, borne on fine Iong stems.

Strong, 2-year, field-grown plants, $75 \mathrm{cts}$. each, $\$ 6$ for 10 , except where noted

Remember, 5 of more plants of one kind are sold at the 10 rate

American Pillar. A very lusty climber with bold, waxy foliage, bearing tremendous clusters of Iarge, sparkling pink, single flowers with a round white eye and bright golden stamens.

Aviateur Bleriot. Beautiful twining growth with holly-like leaves and lemony buds which open to clusters of medium-sized, beautifully shaped, white flowers with pale yellow centers. $\$ 1$ each, $\$ 9$ for 10 .

Climbing American Beauty. A moderate-growing pillar Rose which blooms very early, producing very large flowers of delightful shape and a rare shade of light purple-red unlike any other. The blooms are richly fragrant, and it is one of the most desirable varieties. 75 cts. each, $\$ 6.50$ for 10 .

Dr. W. Van Fleet. A vigorous, shining-leaved climber which produces beautiful Roses of the Hrbrid Tea type on long stems suitable for cutting. It blooms with the greatest profusion rather late in the season. The flowers are of the palest possible shade of pink, with a slightly darker center. Undoubtedly the most beautiful hardy climbing Rose introduced to date.

Dorothy Perkins. Immense clusters of tiny, exquisitely formed little Roses of rich shell-pink in varying shades of softness and intensity. One of the very best climbers in vigor and abundance of blooms.

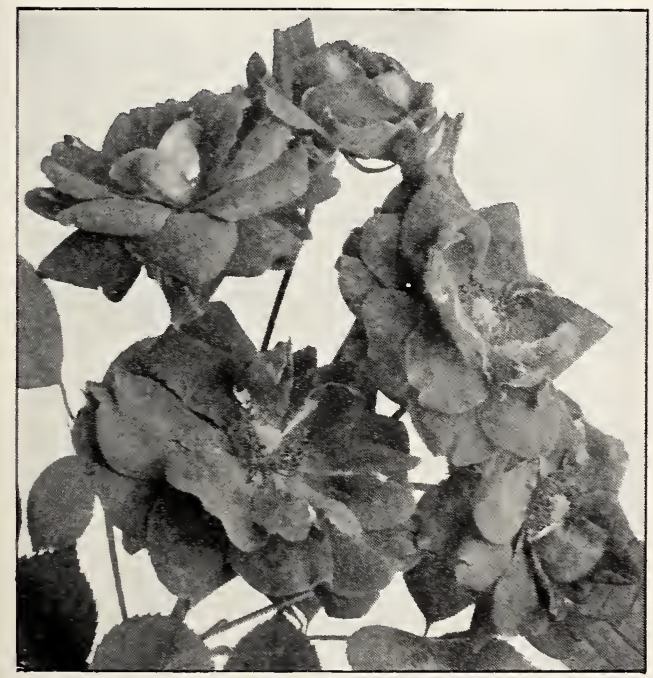

Paul's Scarlet Climber

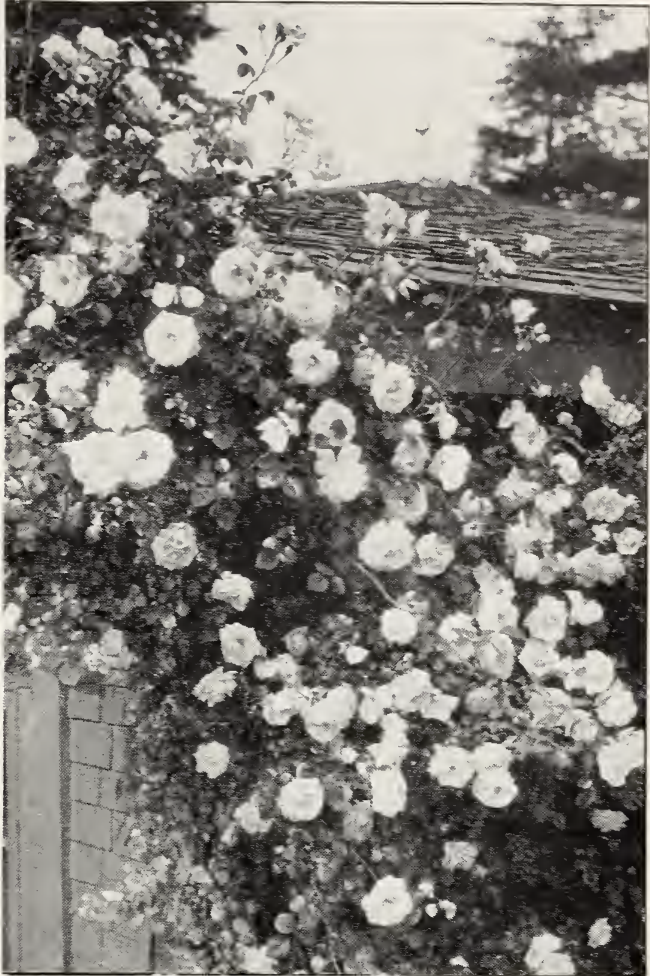

Dr. W. Van Fleet covering a garage

CLIMBING ROSES, continued

Emily Gray. The most beautiful yellow climbing Rose, with large, golden $\tan$ and buff flowers of exquisite beauty. The plant needs protection in severe winters and exposed situation but is worth it. $\$ 1$ each, $\$ 9$ for 10.

Excelsa. Similar to Dorothy Perkins in all respects except the flowers are bright, light crimson.

Gardenia. A strong climber with beautiful foliage and rich yellow buds opening to creamy white flowers with soft yellow centers. One of the hardiest vellow climbers, which are mostly rather tender. 75 cts. each, $\$ 6.50$ for 10 .

Hiawatha. A showy, brilliant red climber with immense trusses of vivid carmine, single flowers with a white eve and a big bunch of yellow stamens. This is one of the brightest and most spectacular Roses grown.

Mary Wallace. Another I arge-flowered climber of the trpe of Dr. W. Van Fleet, except that the blooms are brilliant pink with a yellow undertone and are borne in big clusters. It is a very fine new sort which is becoming verv popular. S1 each, \$9 for 10 .

Paul's Scarlet Climber. Brilliant scarlet flowers of large size on a moderately growing plant suitable for tying to a post or pillar. Very showy.

Primrose. A new, truly vellow variety with large, light primrose-yellow flowers. It has especially handsome foliage, is a good grower, and is much hardier than Emily Gray which is its only rival. We feel that Primrose is the most promising introduction in many vears in the direction of a truly hardy, genuinely yellow, hardy climbing Rose. $\$ 1.50$ each, $\$ 13.50$ for 10 .

Silver Moon. A very strong climber with beautiful waxy green foliage and very large, pure white, semidouble flowers with golden centers.

Tausendschon. A rapid climber with smooth, almost thornless stems and big clusters of large ruffled flowers of many different shades of pink.

White Dorothy. Snowy white double flowers in immense clusters. Plant very vigorous and easily trained 


VINes ANd Climbers $\quad$ THE BAY STATE NURSERIES

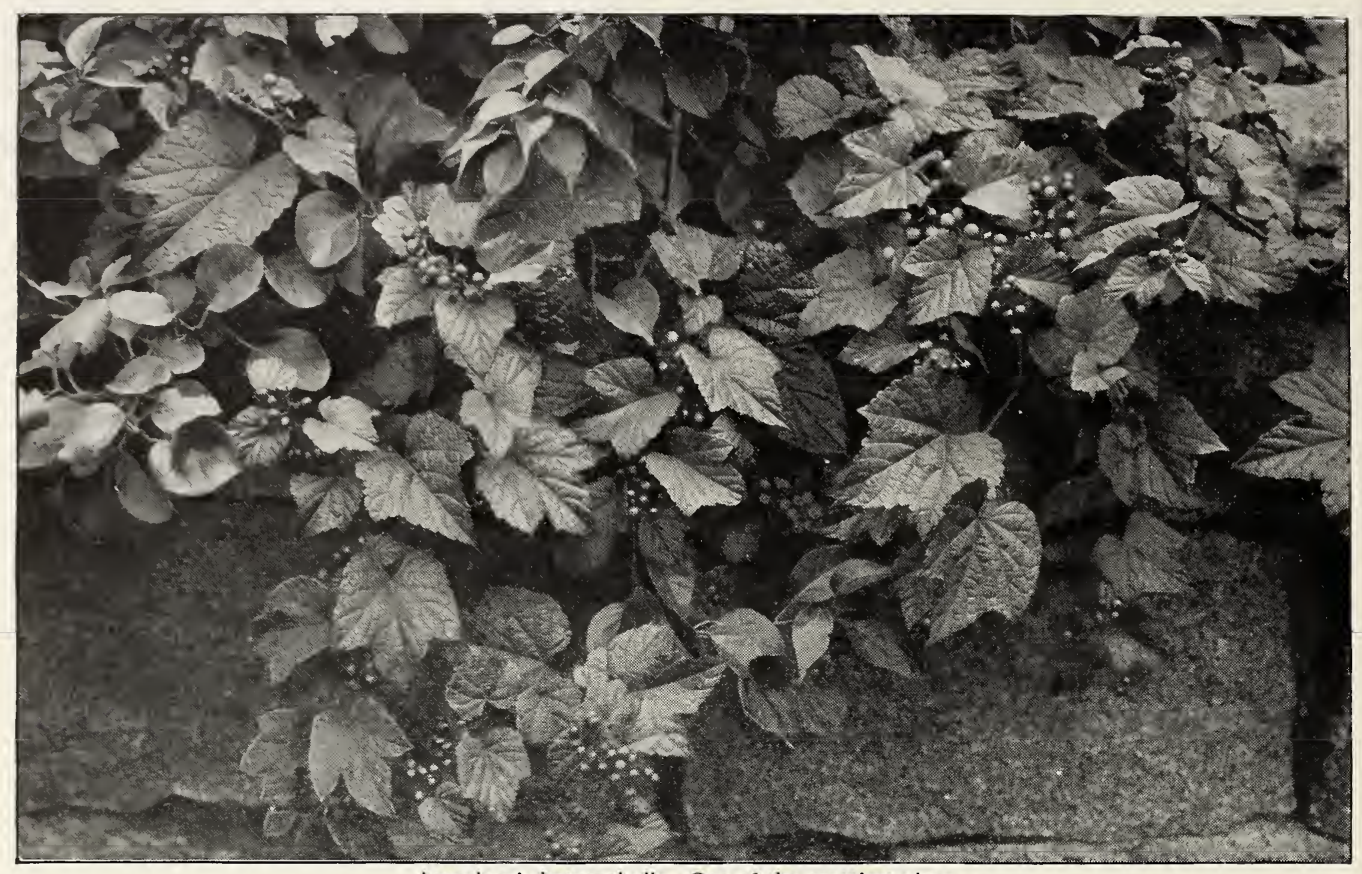

Ampelopsis heterophylla. One of the prettiest vines

\section{VINES AND CLIMBING PLANTS}

$\mathrm{V}$

INES are the gardener's greatest aid in covering up mistakes and concealing ignorance in planning or constructing anything from a garage to a spite fence. They also mitigate the harshness of Nature, throwing a mantle of beauty over dead trees, unsightly rocks, or rough banks, but they have a more definite, positive use, as well. They enhance the beauty of a wail of brick or stucco or stone and provide the only excuse for the lattice trellises and garden arbors which are so abundant in suburban areas. They are good-natured, sheltering, friendly plants and ought to be used generously wherever there is need for shade and comfort.

\section{ACTINIDIA}

Actinidia arguta. Bower Actinidia. A strong-growing Japanese vine, with rather Iarge, handsome leaves. White flowers with purple center and round, edible fruit of sweetish flavor. 3-yr., $\$ 1.25$ each, $\$ 11$ for 10 ; 2 -yr., \$1 each, $\$ 8.50$ for 10 .

\section{AKEBIA}

Akebia quinata. Five-leaved Akebia. A very graceful and rapid-growing vine which is hardy and not attacked by insects. The foliage is fine and it bears rosy purple flowers in early summer, followed by ornamental fruit. 3-yr., 75 cts. each, $\$ 6.50$ for 10.

\section{AMPELOPSIS}

Ampelopsis aconitifolia. Monksbood Vine. A very handsome vine with deeply cut foliage and small blue berries which turn orange as they ripen. 2-yr., 90 cts. each.

A. heterophylla. Porcelain Ampelopsis. Has deeply Iobed leaves, striped with creamy white, and clusters of light blue, showy berries. Good for Iow trelliswork. 3-yr., 90 cts, each, $\$ 7.50$ for $10 ; 2-y r ., 75$ cts. each, \$6.50 for 10 .

A. quinquefolia. Virginia Creeper. A vigorous, high-climbing vine of rapid growth, with rich crimson foliage in autumn. Valuable for covering walls or old tree trunks. $3-y r ., 60$ cts. each, $\$ 4.50$ for 10 ; $2-y r ., 50$ cts. each, $\$ 3.50$ for 10 .
AMPELOPSIS, continued

A. quinquefolia engelmanni. Engelmann Creeper. Quite similar to the preceding variety but has smaller and neater foliage, which adapts it to less rustic effects. It is also a better climber, sticking closer to walls and other supports than Virginia Creeper. 3-yr., 60 cts. each, $\$ 4.50$ for 10.

A. tricuspidata. Japanese Creeper; Boston Ivy. A very useful climber, clinging firmly and covering walls, rocks, and stumps densely. The glossy foliage stands smoke and dust well and turns to a brilliant orange and scarlet in the fall. ,The best substitute for English Ivy. From 4 -in. pots, 75 cts. each, $\$ 7$ for 10; from 3-in. pots, 60 cts. each, $\$ 5.50$ for 10 .

A. tricuspidata robusta. Similar to above, but a stronger grower, with rich, dark foliage. 3-yr., field-grown, 90 cts. each, $\$ 7.50$ for 10 .

\section{ARISTOLOCHIA}

Aristolochia sipho. Dutchman's Pipe. This very vigorous vine is excellent for porches, its immense leaves providing a cool, dark shade. The purple flowers are of most curious, and interesting pipe-like form. 5-yr., $\$ 1.75$ each, $\$ 15$ for 10; 4-yr., $\$ 1.50$ each, $\$ 14$ for 10 ; 3-yr., \$1.25 each, \$11 for 10 .'

A. tomentosa. Southern Dutchman's Pipe. A native species of climbing habit and rapid growth. Good green foliage a little smaller than the preceding variety and the numerous, pipe-shaped flowers are yellow. 3-yr., $\$ 1$ each, $\$ 8.50$ for 10 . 


\section{BIGNONIA}

Bignonia radicans. Trumpet Creeper. A hardy, highclimbing plant, with Iarge, trumpet-shaped flowers of glowing orange-red in August. 4-yr., 60 cts. each, $\$ 5$ for $10 ; 3-y r ., 50$ cts. each, $\$ 4.50$ for 10 .

\section{BOSTON IVY}

See Ampelopsis tricuspidata

\section{CELASTRUS}

Celastrus orbiculatus. Oriental Bittersweet. Ordinarily this plant assumes a shrub-like form, but if given an opportunity will make a tall and vigorous climber. It has bright green leaves and crimson fruit which is handsome in fall and winter. 5-yr. $\$ 1$ each, \$8 for 10; 4-yr., 90 cts. each, \$7.50 for 10 .

C. scandens. American Bittersweet. A native climber, with glossy leaves which turn bright. yellow in autumn, and big clusters of orange and crimson fruit. 2-yr., 75 cts. each, \$6 for 10.

\section{CLEMATIS}

Clematis paniculata. Sweet Autumn Clematis. By far the best of the fall-blooming species. It thrives best in sunny situations, and will stand severe pruning in winter. A Iuxuriant grower and profuse bloomer with fine foliage. The flowers are mediumsized, pure white, very fragrant, and are borne in great profusion. 4-yr., 75 cts. each, $\$ 6$ for 10 ; 3-yr., 60 cts. each, $\$ 5$ for $10 ; 2$-yr., 50 cts. each, $\$ 4$ for 10 .

C. texensis. Scarlet Clematis. A pretty sort, with a profusion of bell-shaped, brilliant scarlet flowers which make a showy display. Foliage light green. 2-yr., 60 cts. each, $\$ 5.50$ for 10.

C. virginiana. Virgin's Bower. This rapid-growing native sort produces clouds of white flowers in August, followed by feathery seeds which are decorative in winter. 3-yr., 50 cts. each, $\$ 3.50$ for 10.

\section{Hybrid Large-Flowering Clematis}

Clematis henryi. A robust, free-blooming plant with creamy white, large, handsome flowers.

C. jackmani. Flowers broad, velvety purple, with ribbed bar down the center. Very popular.

C., Mme. Edouard Andre. Large crimson flowers. Persistent bloomer.

C., Ramona. One of the prettiest of the Clematises with dainty light blue flowers.

C. viticella. Italian Clematis. One of the parents of the large-flowered hybrid Clematis, with bluish purple flowers. 8 to 12 feet high. 40 cts. each, $\$ 3.50$ for 10 .

Any of the above, except where noted, 2-yr. heavy plants, from 6-in. pots, $\$ 1.50$ each, $\$ 12.50$ for 10

\section{HYDRANGEA}

Hydrangea petiolaris. Climbing Hydrangea. A very beautiful, rather rare variety of Climbing Hydrangea, with overlapping, mosaic-like Ieaves and round flat clusters of white flowers. Delightful on a stone wall, and will grow to great height. The fragrance is distinct and delightful and pervades the air for a great distance from the plant. Plants from 3 -in. pots, 75 cts. each, $\$ 7$ for 10 .

\section{LYCIUM}

Lycium chinense. Chinese Matrimony Vine. A vigorous climber, branching freely, and covered with bright purple, star-shaped flowers, which are succeeded by brilliant scarlet berries almost an inch long. 3-vr., $50 \mathrm{cts}$. each, \$4 for 10 .

\section{LONICERA}

Lonicera japonica halliana. Hall Japanese Honeysuckle. A vigorous grower with fragrant yellow and white flowers from midsummer until frost. This makes a good ground-cover. 4 -yr., 60 cts. each, $\$ 4.50$ for 10 3-yr., 50 cts. each, $\$ 4$ for 10.

L. periclymenum belgica. Dutch Woodbine. A Iow climber with very fragrant flowers, pale purple outside, from June till September. $1 \frac{1}{2}$ to $2 \mathrm{ft}$., $75 \mathrm{cts}$. each, \$6.50 for 10 .

L. sempervirens. Trumpet Honevsuckle. One of the best varieties. Its deep crimson flowers are borne profusely in bunches at intervals throughout the summer followed by scarlet berries. 4 -yr., 60 cts. each, $\$ 4.50$ for $10 ; 3-y r ., 50 \mathrm{cts}$. each, $\$ 3.50$ for 10 .

\section{POLYGONUM}

Polygonum auberti. Cbinese Fleece Vine. A tallgrowing, hardy vine, with bronzy young leaves which turn green. The white flowers are borne abundantly in feathery sprays. Very quick-growing and desirable. 2 -yr. plants from 6-in. pots, $\$ 1.75$ each, $\$ 15$ for 10 .

\section{PUERARIA}

Pueraria thunbergiana. Kudzu Bean. A most worthy ornamental vine. It is a very rapid grower, bearing rosy purple, pea-shaped flowers in August. 2 -yr., 50 cts. each, $\$ 3.50$ for 10 .

\section{TECOMA RADICANS. See Bignonia}

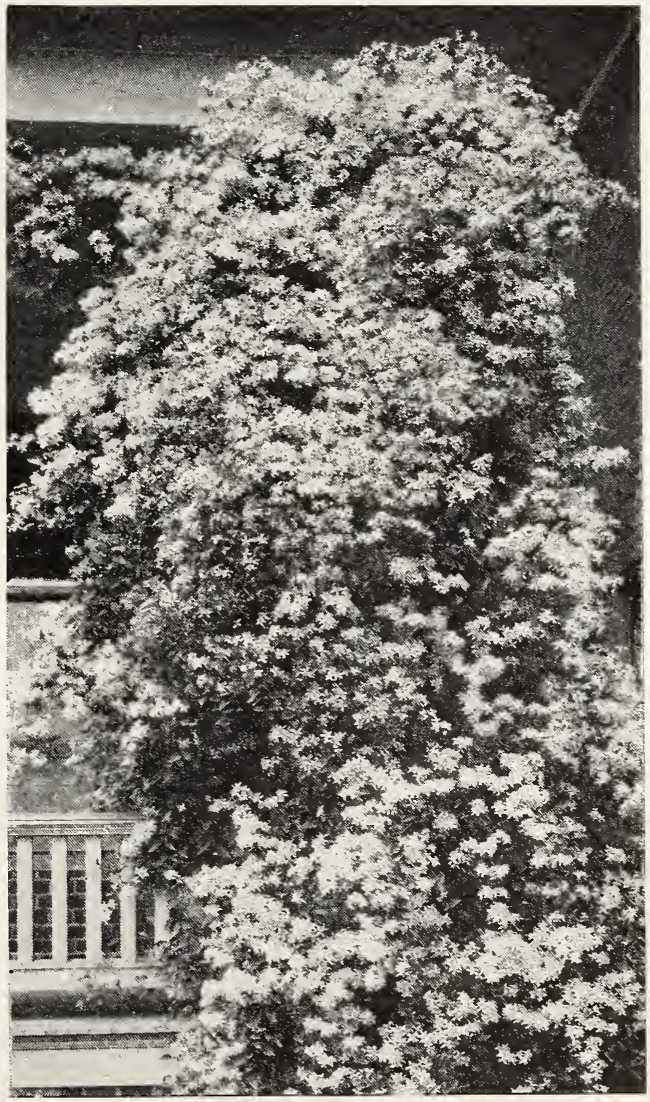

Sweet Clematis. Clematis paniculata makes a cloud of misty, fragrant flowers 


\section{VITIS}

Vitis æstivalis. Summer Grape. A tall climber with large foliage and small, black, tough-skinned berries. 2-yr., 60 cts. each, $\$ 5$ for 10 .

V. cordifolia. Frost Grape. A very vigorous Wild Grape, attaining majestic size with age and providing abundance of foliage for shade. The fruit is black and very good after it has been frosted. 2-yr., 60 cts. each, $\$ 5$ for 10 .

V. heterophylla. See Ampelopsis heterophylla.

V. labrusca. Fox Grape. A strong native vine thought to be the ancestor of most of our finest American Grapes. Especially suited for naturalizing in thickets and wooded corners. 3-yr., 90 cts. each, $\$ 7$ for 10 .

\section{WISTERIA}

Wisteria frutescens magnifica. Yellow-eye Wisteria. Resembles W. frutescens, but produces larger and denser clusters of lilac-colored flowers with yellow spots. 3-yr., 90 cts. each, $\$ 7.50$ for 10 .

W. sinensis. Cbinese Wisteria. Hardy, fast, tall-growing climber, with pale green, compound foliage and long clusters of purplish peashaped flowers in May. 5-yr., $\$ 1.25$ each, $\$ 10$ for $10 ; 4$-yr., $\$ 1$ each, $\$ 8$ for 10 ; 3-yr., 75 cts. each, $\$ 6$ for 10 . 3-yr. plants, grown from cuttings from a blooming plant and sure to bloom, $\$ 1.50$ each.

W. sinensis alba. White Chinese Wisteria. A white-flowered variety of the preceding. 4-yr., $\$ 1$ each, $\$ 8$ for $10 ; 3-y r$. , grafted plants, $\$ 1.50$ each, $\$ 13.50$ for 10 .

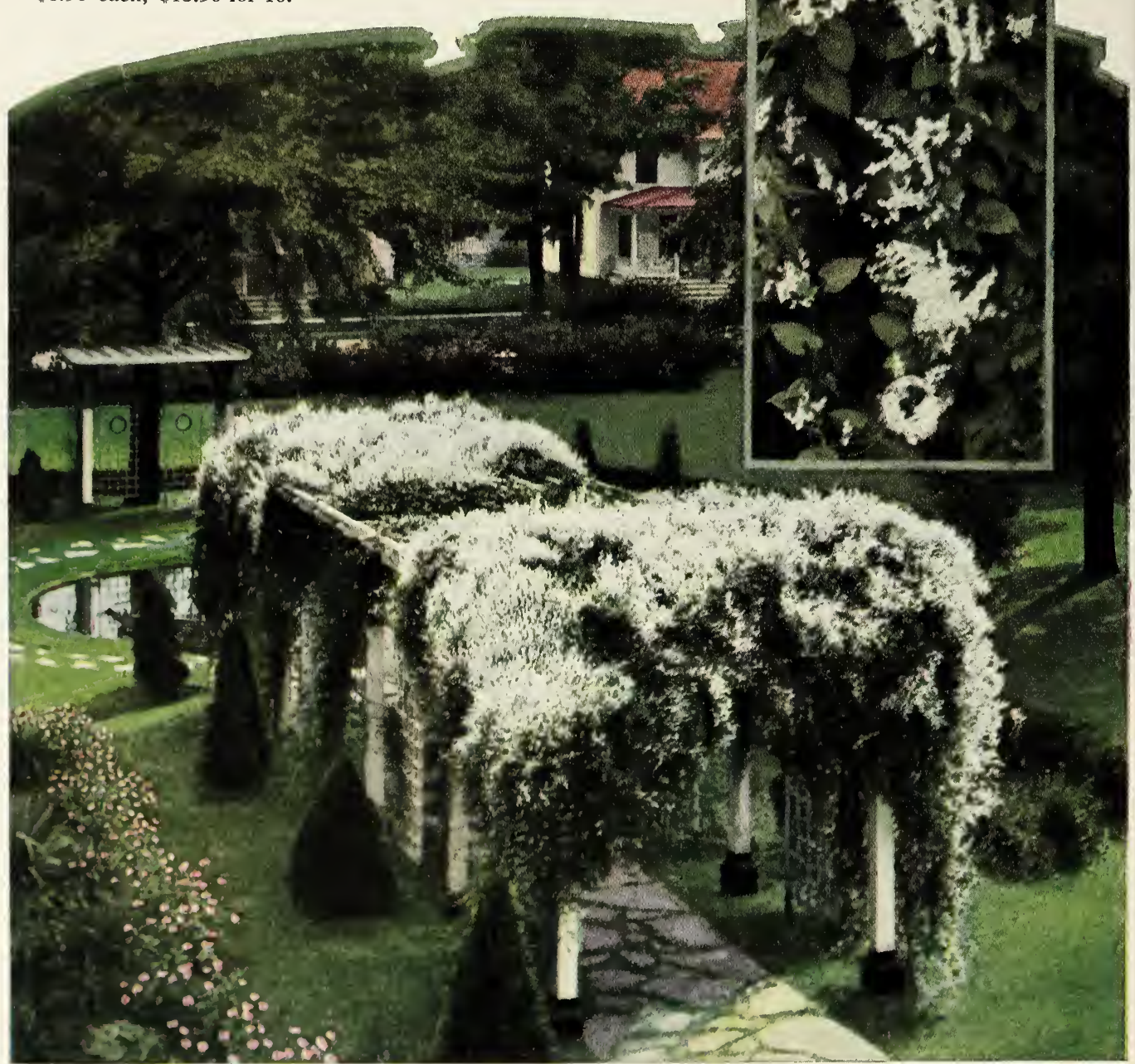

Polygonum auberti. Chinese Fleece Vine. It is next to impossible to give a really good idea of the extreme delicacy of the Chinese Lace Vine, Polygonum auberti, by either words or pictures. Its cob webby beauty is as difficult to fix as the iridescence on a soap-bubble as fragile as frost. See page 45 . 


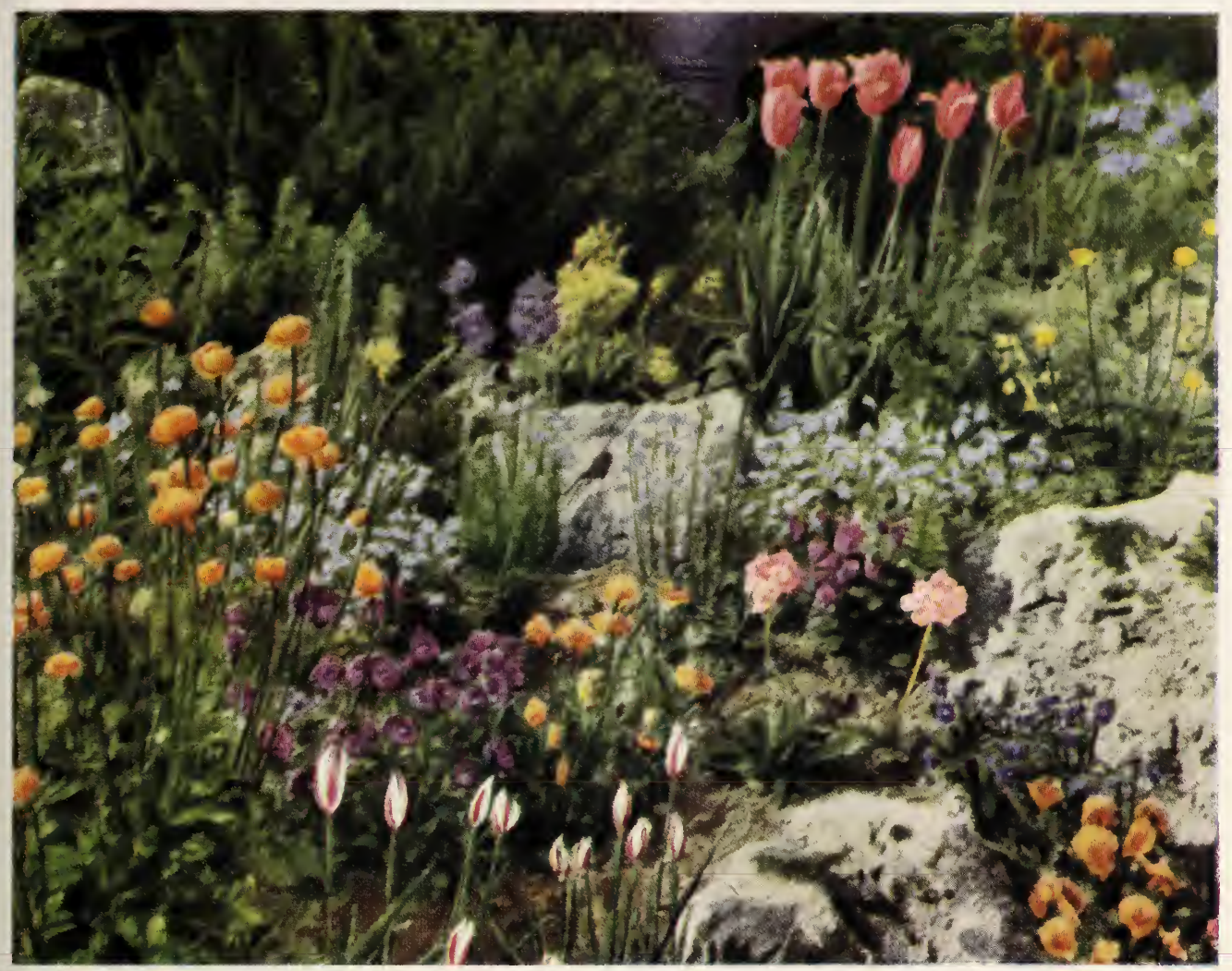

The beauty of a spring rock grden full of charming little perennials such as are marked with the astorisk (*) in the following list

\section{HARDY PERENNIALS}

No experienced flower-lover needs be told about the importance of Hardy Perennials in successful gardens. Beginners should understand that these plants are long-lived, growing Iarger and finer from year to year, and if the soil is well and deeply prepared for them at the start, they need not be reset for several seasons. They comprise most of the showiest and the strongest-growing flowers, and must form the foundation of any garden.

They exist in infinite variety, ranging in size from the tiniest edging material to tall, robust plants suitable for massing as a background, and in color through all the shades of the rainbow and a lot more.

A garden wholly of perennials is possible, and it is a delightful game to plan its arrangement so that one variety may succeed another in bloom, and provide a season-long procession of different flowers, in evervarying forms and colors.

For best effect it is essential to plant in clumps, masses, or drifts of one kind. Such masses should be large enough to do justice to the flowers. The bigger the plants grow, naturally the fewer are required to make a proper display. Generally, however, at least five or six are required, even of the largest kinds, and the smaller sorts should be planted by the dozen or even hundred.

We have grown Perennials successfully for a number of years, and our acreage has been extended from year to year to supply the increasing demand for them.

We add new and choice sorts every year, and our stock includes an unusually large variety. In our descriptions we have indicated the height each plant attains and the months when the flowers appear.

About Prices. We do not sell one plant of a kind, except Astilbes, Irises, and Peonies. Our price is based on About Prices. 3 of one kind. Too many people try to make gardens by using only one plant of a variety, a procedure bound to lead to disappointment. Three plants at least and, better still, five or ten of a kind, are almost always necessary to do justice to a variety or to produce the mass and color effect desired.

Except where otherwise indicated, the price of all Hardy Perennials listed is $90 \mathrm{cts}$. for $3, \$ 2.40$ for 10 , $\$ 18$ per 100

Five or more plants of one kind will be sold at the 10 rate and 25 or more of one kind at the 100 rate when it is given. Ten plants of different kinds, such as 10 different varieties of Asters, will not be sold at the 10 rate. The lower rate applies only when five or more plants of one variety are ordered.

By consulting the following list, one can plant a garden or border which will produce a succession of bloom from early spring until late in the autumn. Almost all our plants are strong, freld-grown sorts, except a few species which transplant better if they are grown in pots.

Those marked with an asterisk (*) are particularly adapted to the rock garden 


\section{ACANTHUS}

Acanthus mollis latifolius. Broadleaf Acantbus. $2 \mathrm{ft}$. July and August. Purple flowers in loose spikes high above the ornamental foliage. Good in the border or rock garden. $\$ 1.20$ for $3, \$ 3.50$ for 10 , $\$ 24$ per 100.

\section{ACHILLEA - Yarrow}

The Achilleas are a large family and provide many useful garden plants. They vary immensely from flat, mat-like forms to tall, bold specimens closely approaching shrubs. As they delight in dry, sunny locations, they are useful in many difficult places in the garden or border. Most of them have pungent, aromatic foliage.

*Achillea ageratum. Sweet Yarrow. 12 to 18 in. July to October. Flat heads of pale yellow flowers and silvery fern-like foliage. Excellent for covering dry, bare places.

*A. filipendulina. Fernleaf Yarrow. 3 to $4 \mathrm{ft}$. June to September. Flowers bright yellow, in flat heads. Neat foliage. A bold, handsome plant. 75 cts. for $3, \$ 2.20$ for $10, \$ 15$ per 100 .

*A. millefolium. Common Yarrow. 18 to 24 in. July. Fine fern-like leaves and flat heads of white flowers. 75 cts. for $3, \$ 2.20$ for $10, \$ 15$ per 100 .

*A. millefoiium, Cerise Queen. 15 to 20 in. June to November. A highly developed form of the above with cherry-red flowers on long stems.

*A. millefolium rosea. Pink Yarrow. $18 \mathrm{in.} \mathrm{June} \mathrm{to}$ October. Rosy pink flowers in dense heads. Effective on edge of shrubbery or in border. $75 \mathrm{cts}$. for $3, \$ 2.20$ for $10, \$ 15$ per 100 .

A. ptarmica, Boule de Neige. 12 to $18 \mathrm{in.} \mathrm{A} \mathrm{fine}$ white variety similar to The Pearl, but has fuller and more perfect flowers, and does not grow as talI.

A. ptarmica, Perry's White. $2 \mathrm{ft}$. June to September. A choice new variety, bearing pure white flowers over an inch across, with broad, overlapping petals. Nothing better for cutting.

A. ptarmica, The Pearl. $2 \mathrm{ft}$. July to October. Small heads of pure white flowers borne in great profusion on strong wiry stems. It is of great value for mixing with other cut-flowers. 75 cts. for 3 , $\$ 2.20$ for 10 , \$15 per 100 .

*A. tomentosa. Woolly Yarrow. 5 to 6 in. JuIy to September. Bright yellow woolly flowers. Excellent for edging and rockeries.

\section{ACONITUM • Monkshood}

One of the difficult garden problems is solved by the Aconites. They provide the rare and highly prized blue color late in the season, when there is a predominance of yellow and red, and make an excellent substitute for DeIphiniums which are past their best when the Aconites begin. Then, too, they seem to be indifferent, more or less, to Iocation, thriving weIl in the shade. Contrasted with Helianthus and Rudbeckias, or the white Cbrysantbemum maximum and the forms of Anemone japonica, they are especially pleasing. They require several seasons to get in their best form and should therefore be disturbed as infrequently as possible.

Aconitum autumnale. Autumn Monkshood. 4 to $5 \mathrm{ft}$. September to frost. Large spikes of dark blue, curiously hooded flowers. Especially good for shady places. $\$ 1.50$ for $3, \$ 4$ for $10, \$ 25$ per 100 .

A. autumnale barbatum. $11 / 2$ to $3 \mathrm{ft}$. June and July. Flowers are bluish violet tipped darker. An excellent early-flowering dwarf sort. \$1.05 for 3 , S3 for 10 .

A. fischeri. Azure Monksbood. $11 / 2$ to $2 \mathrm{ft}$. September and October. Short spikes of Iarge, clear blue flowers and bright, glossy foliage. One of the finest for late flowers. \$1.20 for 3, \$3.50 for $10, \$ 25$ per 100 .

\section{ACONITUM, continued}

A. fischeri wilsoni. 5 to $6 \mathrm{ft}$. September. A recent introduction from northern China, of strong, stately habit, with light violet-blue flowers. This is an extremely handsome variety, producing a profuse display of lovely light blue at the time this color is rarest and most appreciated in the garden. The stock has been extremely scarce. $\$ 2.25$ for $3, \$ 6$ for 10 , $\$ 50$ per 100 .

A. lycoctonum. Wolfsbane. $3 \mathrm{ft}$. June to September. A very curious species with yellow flowers, making a decided contrast with the dark blue of the other varieties. $\$ 1.20$ for $3, \$ 3.50$ for 10 .

A. napellus. Aconite. 3 to $4 \mathrm{ft}$. JuIy and August. Long spikes of Iarge, dark blue flowers. One of the oldest and best-liked varieties. $\$ 1.05$ for $3, \$ 2.70$ for $10, \$ 24$ per 100 .

A. napellus bicolor. Bicolor Aconite. 2 to $21 / 2 \mathrm{ft}$. July and August. This variety has variegated blue and white flowers, which are very effective. $\$ 1.20$ for $3, \$ 3.50$ for 10 .

A. napellus, Sparks. Sparks'Aconite. $21 / 2$ to $4 \mathrm{ft}$. July. Very dark blue flowers. One of the finest Aconites because of its free-blooming quality, and makes a fine display for a long time. $\$ 1.05$ for $3, \$ 3$ for $10, \$ 25$ per 100 .

A. uncinatum. Clambering Monksbood. 3 to $5 \mathrm{ft}$. June to September. Stems slender, inclined to climb, with thick, deeply cut leaves and dark purple flowers $\$ 1.05$ for $3, \$ 2.50$ for $10, \$ 20$ per 100 .

\section{ACORUS - Sweet Flag}

Acorus calamus. Sweet Flag. $2 \mathrm{ft}$. June and early July. A swamp or water plant. Slender, sword-like leaves. 75 cts. for $3, \$ 2.20$ for $10, \$ 15$ per 100 .

A. calamus variegatus. Yellow-stripe Sweet Flag. Same as the preceding, except the ribbon-like foliage is striped with green and gold. 75 cts. for $3, \$ 2.20$ for 10 .

\section{ACTÆA - Baneberry}

Actæa alba. White Baneberry. 1 to $2 \mathrm{ft}$. May and June. Similar to Red Baneberry but the berries are china white on red stems. Very decorative. Best in shady places.

A. rubra. Red Baneberry. $1 \frac{1}{2}$ to $2 \mathrm{ft}$. May and June. An erect plant with showy spikes of white flowers, followed by handsome clusters of red berries.

\section{ÆEGOPODIUM • Goutweed}

* Egopodium podograria variegatum. Silver-edge Goutweed. 12 to $15 \mathrm{in.}$ Late in May and June. A rapid-growing plant with decorative whitemargined leaves. Fine for edgings, rock gardens, and for covering barren places.

\section{AJUGA}

*Ajuga genevensis. Geneva Bugle. 6 to 8 in. May. Long, showy spikes of bright blue flowers. Adapted for carpeting or bedding in shady borders.

*A. reptans rubra. Purple-leaved Bugle. 5 to 6 in. Early May to mid-June. A dense, creeping plant with numerous blue flewers on erect spikes. Good for carpeting shady places.

\section{ALLIUM}

*Allium thibetica. A fine rock plant, with a cluster of dark green, slender foliage from which rise slender stems, 6 to 8 inches high, bearing clusters of Iilac-mauve flowers in June and July.

\section{ALTHÆA ROSEA - Hollyhock}

Like roses, no one needs an introduction to the Hollyhocks. They are familiar, friendly flowers which have that home-like, old-fashioned air so desirable in the garden. Especially effective against 


\section{ALTHFA ROSEA, continued}

a fence or stone wall, massed in corners, or clustered against a gate, they are also splendid at the back of the flower-border, or wherever a tall, slender, but self-supporting plant is desired. Their color-range is almost limitless, blue and golden yellow alone being missing. We grow all the good strains obtainable, and offer strong, freld-grown plants.

Double Varieties. Apple-blossom, Blood-Red, Crimson, Deep Rose, Dr. Faust, Pink, Salmon, White, and Yellow. 75 cts. for 3, \$2.20 for $10, \$ 15$ per 100 Single Varieties. Pink, Red, White, and Yellow. 75 cts. for $3, \$ 2.20$ for 10 , \$15 per 100 .

Allegheny. This strain produces giant fringed flowers in a wide range of handsome colors. 75 cts. for 3 $\$ 2.20$ for 10 , \$15 per 100 .

Orange King. A double variety with yellow outer Detals and a tufted center of orange-apricot. One of the most intensely colored and beautiful of all. $\$ 1.20$ for $3, \$ 3.50$ for 10 .

\section{ALYSSUM}

The Alyssums are useful edging plants. The annual Sweet Alyssum is probably more used than any other kind. The perennial sorts offered here are somewhat taller and some of them bloom very early in the season, providing low edging plants at a time most annual edgings are not yet in flower. Good rock plants and require no special treatment, although they like plenty of sunlight.

*Alyssum argenteum. Silver Alissum. 12 to 15 in. June to August. The yellow flowers come in dense clusters, with small white leaves beneath, giving a peculiarly beautiful silver effect. Suitable for rock garden and border. 75 c. for $3, \$ 2.20$ for $10, \$ 15$ per 100 .

*A. rostratum. Yellow-bead Alyssum. $1 \mathrm{ft}$. June and July. Bright golden yellow flowers in dense heads. A very useful sort.

*A. saxatile compactum. Duarf Goldentuft. $1 \mathrm{ft}$. Mid-April to June. A very showy spring plant for the rockery or border, having fragrant yellow flowers in clusters, and silvery foliage. 75 cts. for $3, \$ 2.20$ for $10, \$ 15$ per 100 .

*A. saxatile sulphureum. $1 \mathrm{ft}$. April to June. The very abundant flowers are a soft creamy shade of sulphur-yellow which combines well with soft blue blooms, like forget-me-nots. 90 cts. for 3 , $\$ 2.50$ for 10 , $\$ 20$ per 100 .

\section{AMSONIA}

Amsonia salicifolia. Willow Amsonia. $11 / 2$ to $21 / 2 \mathrm{ft}$ Late May and early June. Shrubby habit, with stiff willow-like leaves which are held Iate, and smal light blue flowers with white throats.

A. tabernæmontana. Willow Amsonia, 2 to $3 \mathrm{ft}$ Late May and early June. Small gravish blue flowers in panicles, but the beauty of the plant is in its stiff olive-like foliage which remains in perfect condition all season.

\section{ANCHUSA • Bugloss}

A very variable race of plants which provides the much-desired blue flowers. They do well in borders in full sun, but the Dropmore variety seems to prefer a little shade.

Anchusa barrelieri. Early Bugloss. 2 to $3 \mathrm{ft}$. May and June. A bushy plant bearing an abundance of small, dark blue flowers with light pink or yellowish throats.

A. italica. Italian Bugloss. 3 to $4 \mathrm{ft}$. Large heads of fine blue flowers in June, similar to very large forgetme-nots. Rough leaves and stems.

A. italica, Dropmore. Dropmore Bugloss. 4 to $5 \mathrm{ft}$. May. An improved variety of the preceding, with rich gentian-blue flowers. One of the most desirable perennials.
ANCHUSA, continued

A. italica, Opal. Opal Bugloss. 3 to $4 \mathrm{ft}$. Summer. Much like Dropmore but has very beautiful Iarge pale blue flowers.

*A. myosotidiflora. Siberian Bugloss. 10 to 12 in. April and May. A distinct, dwarf perennial variety from Russia, with clusters of charming blue flowers resembling forget-me-nots. An effective rock plant for shady places. \$1.20 for 3, \$3.50 for $10, \$ 24$ per 100 . A. sempervirens. Evergreen Bugloss. $3 \mathrm{ft}$. July. Lavender-blue flowers and broad, almost evergreen leaves.

\section{ANEMONE}

There are two distinct classes of Anemones. The early sorts are mostly dwarf, and are charming little plants for woodland or rockery. The Japanese sorts bloom in Iate summer and faII, are much taller, and form fine big clumps that have an artistic grace unequaled by any other flowers in their season. They look especially well against a background of evergreens, and are equally effective in the middle of the perennial border.

Anemone canadensis. Meadow Anemone. 1 to $2 \mathrm{ft}$. May to July. White, cup-shaped flowers an inch across, borne in a cluster of three large leaves. One of the best of our native Anemones and adapted to shady positions where it makes a fine level growth of lovely foliage. Fine for naturalizing.

A. hupehensis. Cbinese Anemone. A perfect little gem, closely allied to $A$. japonica which it resembles in a miniature way. It grows from 18 to 24 inches high, and produces an abundance of pleasing mauverose flowers about $11 \%$ inches across, from early in August until late in autumn. 90 cts. for 3, \$2.50 for $10, \$ 20$ per 100 .

A. japonica. Japanese Anemone. $2 \mathrm{ft}$. Fall. Beautiful rosy red flowers with bright yellow stamens.

A. japonica alba. Wbite Japanese Anemone. $3 \mathrm{ft}$. Fall. Glistening white flowers, useful for cutting.

A. japonica, Alice. 2 to $3 \mathrm{ft}$. Autumn. Verv Iarge flowers of pale silvery rose-pink. $90 \mathrm{cts}$. for 3, \$2.50 for $10, \$ 20$ per 100 .

A. japonica, Lady Ardilaun. 2 to $3 \mathrm{ft}$. Fall. Pure white variety, with overlapping petals.

A. japonica, Mt. Rose. $3 \mathrm{ft}$. September to November. Very large, double flowers of delightfuI rose-pink color. 90c. for $3, \$ 2.50$ for $10, \$ 20$ per 100 .

A. japonica, Prince Heinrich. 2 to $3 \mathrm{ft}$. Fall. Large, very double, dark pink, almost red flowers, borne very freely. 90 cts. for $3, \$ 2.50$ for $10, \$ 20$ per 100.

A. japonica, Queen Charlotte. $3 \mathrm{ft}$. Fall. Large, semi-double, deep pink flowers. Desirable for cutting; is well known and widely planted.

A. japonica, Richard Arends. $4 \mathrm{ft}$. Autumn. Glistening white, single flowers, sometimes tinted with lavender. Vigorous plant. 90 cts. for $3, \$ 2.50$ for $10, \$ 20$ per 100 .

A. japonica rosea superba. $2 \mathrm{ft}$. Fall. Flowers of medium size, delicate silvery rose-color, borne profusely on rigid stems.

A. japonica, Whirlwind. $3 \mathrm{ft}$. Fall. Large, semidouble, snowy white flowers with a whorl of green around base of petals.

*A. pulsatilla. European Pasque Flouer. 9 to 12 in. April and May. Well adapted for border or rockwork. Flowers blue to reddish purple.

*A. pulsatilla rubra. Red European Pasque Flower. 9 to $12 \mathrm{in.} \mathrm{April} \mathrm{and} \mathrm{May.} \mathrm{A} \mathrm{red-flowering} \mathrm{form} \mathrm{of}$ A. pulsatilla. Fine for rockery or border. \$1.05 for 3, \$2.70 for $10, \$ 24$ per 100 .

*A. sylvestris. Snowdrop Anemone 12 to 15 in. April to July. Large creamy white flowers which nod gracefully. Foliage deeply cut at top, hairy beneath. Good in border or partial shade.

\section{ANTENNARIA}

*Antennaria dioica. Common Pusst-Toes. A low, rosette-like plant for rockery. White, woolly flowers on short, erect stems. Suitable for dry, sunny places 


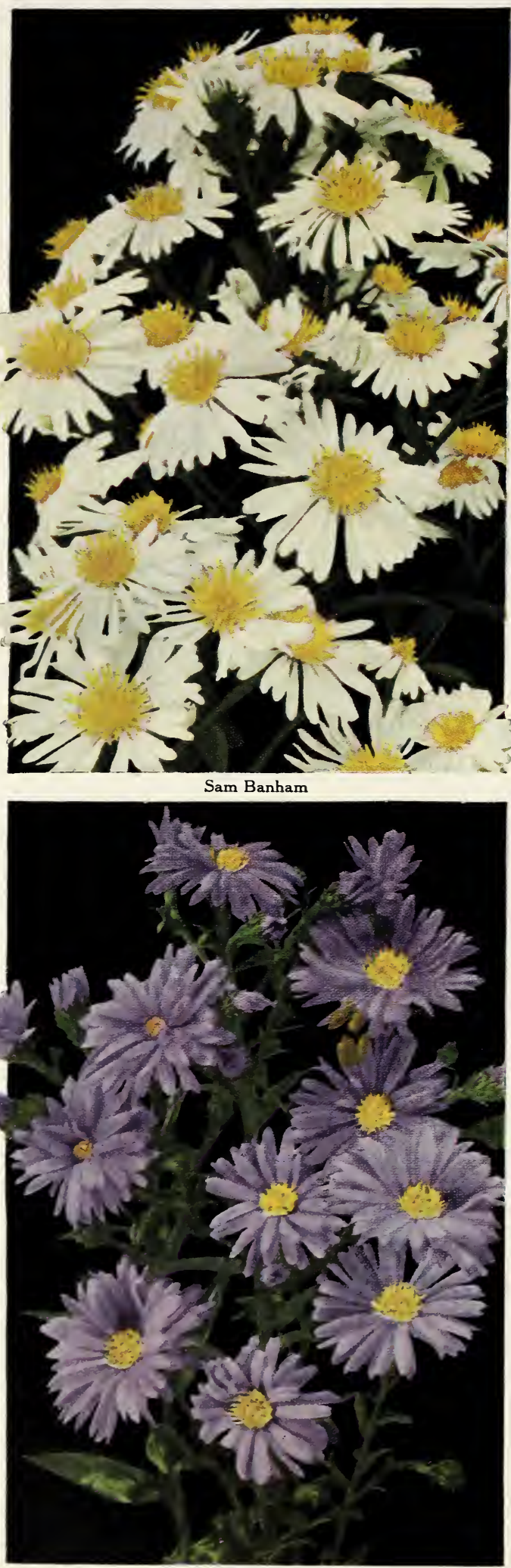

Blue Gem

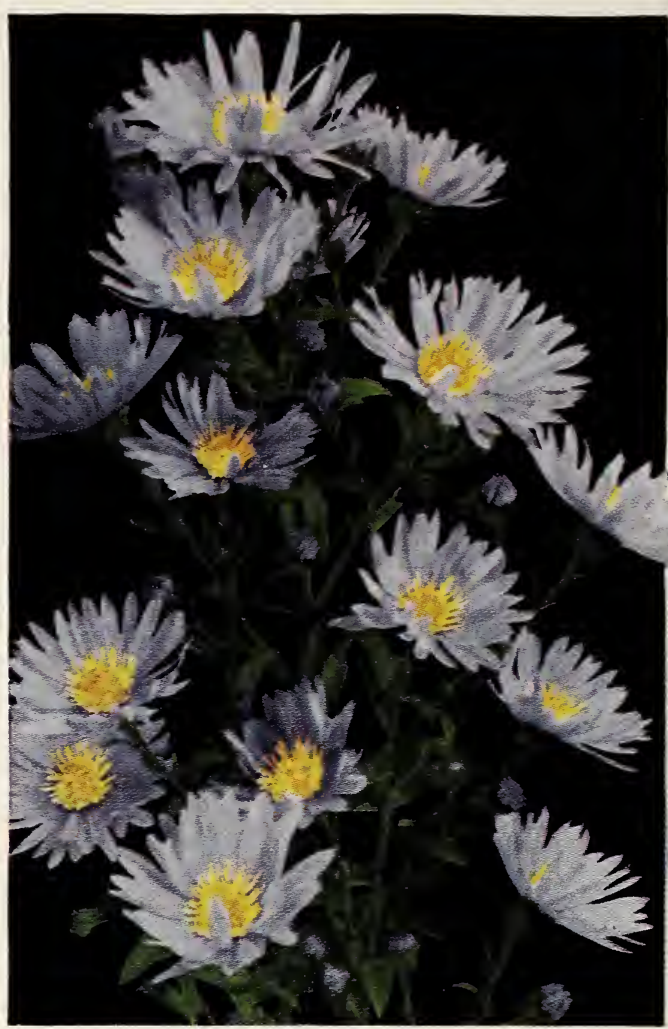

Queen Mary

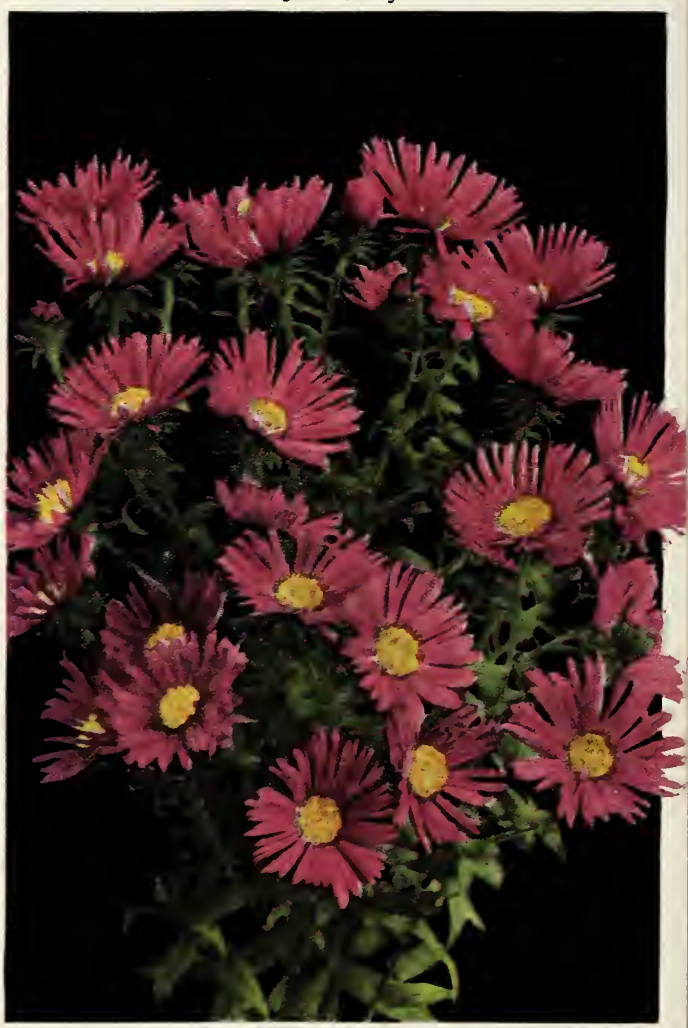

Roseus superbus

Distinct and charming Hardy Asters. See page 53 


\section{ANTHEMIS - Camomile}

These are very hardy bushy plants with daisylike flowers and strongly scented pungent foliage. They are excellent and enduring subjects for the perennial border and require only ordinary soil and full sunlight.

Anthemis nobilis. Common Camomile. 18 in. Summer. Single, white-rayed flowers. A beautiful bushy plant with fern-like foliage. Well-known medicinal herb.

A. tinctoria. Yellow Camomile. 2 to $3 \mathrm{ft}$. June to November. Of bushy habit, with angular stem and daisy-like golden yellow flowers, 1 to 2 inches across.

A. tinctoria kelwayi. Kelway Camomile. 2 to $3 \mathrm{ft}$. June to October. Pretty Iemon-yellow flowers similar to the preceding. Good for cutting and for the border.

A. tinctoria, E. C. Buxton. 2 to $3 \mathrm{ft}$. June to October. A similar variety to above, with creamcolored flowers. 90 cts. for $3, \$ 2.50$ for $10, \$ 20$ per 100 .

\section{ANTHERICUM}

Anthericum liliago. St. Bernard's Lily. 2 to $3 \mathrm{ft}$. May and June. A very decorative specimen or border plant with slender, ribbon-like Ieaves and tall stems bearing loose spikes of starry white flowers tipped with green. Of very easy culture. $\$ 1.05$ for $3, \$ 2.70$ for $10, \$ 20$ per 100 .

A. liliago giganteum. See Paradisea.

\section{AQUILEGIA - Columbine}

The Columbines are among the best-known and best-liked plants, thriving, as they do, under many diverse conditions of sun, shade, and varying soil. They are especially good at the edge of a shady border or among the ground-cover beneath densely foliaged trees. They combine well with almost all plants, but show up especially well with hemerocallis, pachysandra, wild ferns, Filipendula bexapetala, various irises, trollius, and Iupines. For rockeries, the native Canadensis is superb. They are persistent perennials, although they are likely to disappear unaccountably. As they seed very freely, there are always new plants to replace missing ones.

*Aquilegia cærulea. Colorado Columbine. 1 to $11 / 2 \mathrm{ft}$. May to July. Outside petals blue and throat white. Long-spurred flowers.

*A. canadensis. American Columbine. $2 \mathrm{ft}$ May and June. Our weII-known native species, with scarlet sepals and bright yeIlow petals. One of the gayest of aII flowers and most usefuI for rock gardens. 75 cts. for 3 , $\$ 2.20$ for $10, \$ 15$ per 100 .

*A. chrysantha. Golden Columbine. $3 \mathrm{ft}$. June to August. Numerous fragrant and showy golden yellow flowers, with long, slender spurs.

*A. flabellata nana. Fan Columbine. 8 to 12 in. June. Dwarf, compact species with showy purple or Iilac flowers. Excellent for rock gardens. $75 c$. for $3, \$ 2.20$ for $10, \$ 15$ per 100 .

*A. flabellata nana alba. Wbite Fan Columbine. 8 to 12 in. June. A dwarf white form of the above. 75 cts. for $3, \$ 2.20$ for 10 $\$ 15$ per 100 .

*A. formosa, Long-spurred Hybrids. California Columbine. 2 to $3 \mathrm{ft}$. May to July. Large flowers of a bewildering wealth of del icate colors. Spurs very long and fine. Foliage broad and ornamental.

A. skinneri. Mexican Columbine. $2 \mathrm{ft}$. May and June. Crimson sepals lined with light green petals and long, straight, crimson spurs. Good border plants. 75 cts. for $3, \$ 2.20$ for 10 , $\$ 15$ per 100 .

\section{AQUILEGIA, continued}

A. vulgaris. European Columbine. $2 \mathrm{ft}$. May to July. Flowers in all shades of blue, white, red, and purple. Strong, vigorous habit of growth. An effective border plant. 75 cts. for $3, \$ 2.20$ for 10 , $\$ 15$ per 100

A. vulgaris alba. Wbite European Columbine. 2 to $3 \mathrm{ft}$. May and June. Large, pure white flowers valuable for cutting.

A. vulgaris nivea. Munstead Wbite Columbine. 2 to $3 \mathrm{ft}$. Early spring. Produces a great profusion of large, pure white flowers. 75 cts. for $3, \$ 2.20$ for 10 , $\$ 15$ per 100.

A., Mrs. Scott Elliott's Hybrids. Various shades of pink. $\$ 1.05$ for $3, \$ 2.70$ for $10, \$ 20$ per 100 .

\section{ARABIS - Rock Cress}

These are edging plants of the highest quality, producing a mat of white flowers very early in the season, and providing a soft, grayish green carpet throughout the rest of the season. Splendid both for rockwork and edging borders.

*Arabis albida. Wall Cress. 6 to 9 in. May. Fragrant white flowers in clusters. Especially adapted to stony banks.

*A. albida flore-pleno. Double-flowering form of the above. Very desirable. $\$ 1.05$ for 3, \$3 for 10 .

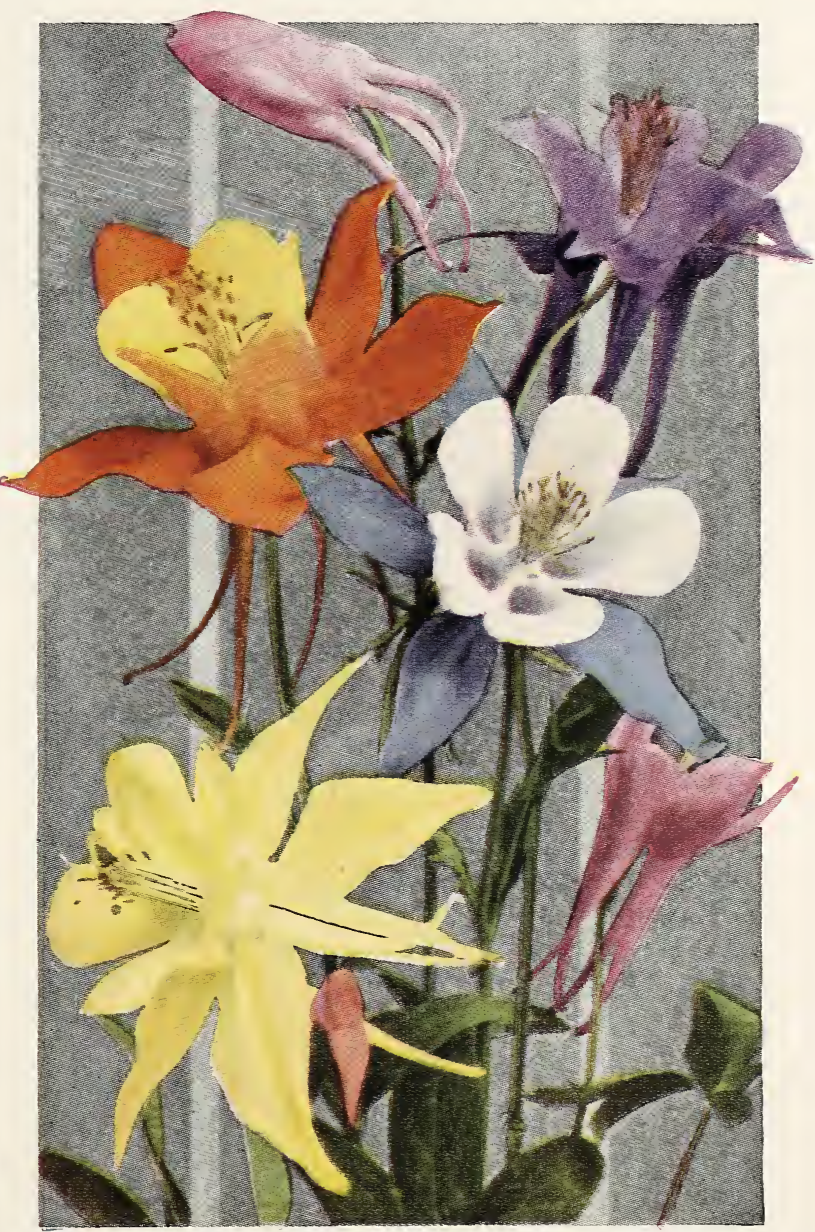

A mere suggestion of the many tints and colors in the Columbines 


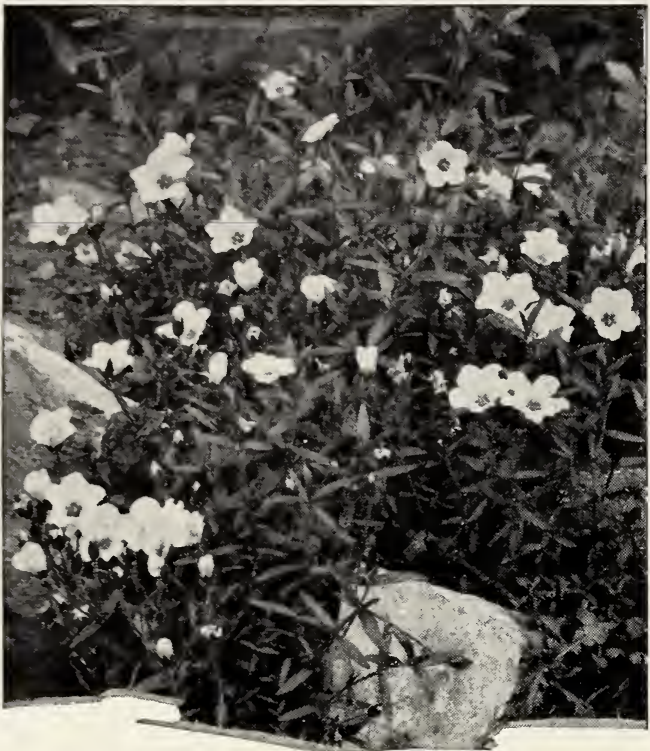

Arenaria montana. A glittering white gem for the rock garden ARABIS, continued

*A. alpina. Alpine Rock Cress. 9 in. April and May. Flowers smaller but similar to the former variety and produced in even greater profusion. One of the best rock plants. 75 cts. for $3, \$ 2.20$ for 10 , $\$ 15$ per 100 .

*A. alpina nana compacta. Dwarf Alpine Rock Cress. 6 in. or Iess. April and May. Similar to the preceding but lower and denser.

*A. mollis. Early spring. Glossy tufted plants bearing clouds of white flowers. Foliage attractive all season. $\$ 1.05$ for $3, \$ 3$ for $10, \$ 20$ per 100 .

\section{ARENARIA - Sandwort}

*Arenaria balearica. Corsican Sandwort. 4 in. June. White flowers. Suitable for rockwork. $\$ 1.05$ for 3 . $\$ 2.70$ for $10, \$ 24$ per 100 .

*A. montana. Mountain Sandwort. 4 to 6 in. May and June. Very desirable evergreen trailing plant, forming a dense carpet of foliage and covered with large white flowers. Splendid for the rock garden.

*A. verna cæspitosa. Moss Sandwort. 1 to 3 in. June. A compact, mossy plant with smalI flowers on thread-like stems which creeps along the ground and between stones. Excellent for the rock garden and informal flagged walks.

\section{ARMERIA . Thrift}

For the edging plants which are commonly called Armeria, see Statice.

\section{ARRHENATHERUM • Oat Grass}

*Arrhenatherum bulbosum variegatum. Variegated Oat Grass. 6 to 12 in. A dwarf grass with variegated green and white leaves. Makes a fine edging along a shrub-border, or good foliage masses among other perennials.

\section{ARTEMISIA • Wormwood}

This family embraces many aromatic and bitter herbs from which various drugs are extracted. Mostly they are used in the garden for their beautiful foliage effects, but $A$. vulgaris lactiflora is a handsome flowering plant which has attracted considerable attention and has found many decorative uses in garden schemes. AII these plants delight in poor, dry soil and in sunny situations, a fact that gives them unusual importance.

Artemisia abrotanum. Old Man; Southernwood. 3 to $4 \mathrm{ft}$. Flowers inconspicuous. Foliage deep green, pleasantly fragrant, and frnely cut. $\$ 1.50$ for 3 , $\$ 4.50$ for 10 .

A. absinthium. Common Wormwood. 2 to $4 \mathrm{ft}$. Flowers unimportant. An old-fashioned garden herb from which the bitter wormwood tea is brewed.

A. dracunculus. Tarragon. $3 \mathrm{ft}$. Another oldfashioned herb with dark green, pointed foliage, which is used for flavoring. $\$ 1.05$ for $3, \$ 2.70$ for 10 , $\$ 20$ per 100 .

A. pontica. Roman Wormwood. 9 to 12 in. Shrubby, erect plants with handsome silvery foliage and whitish yellow flowers in nodding heads.

A., Silver King. Ghost Plant. $3 \mathrm{ft}$. July. White, silvery leaves and sprays of mist-like flowers, useful for cutting and for lightening heavy color combinations in the border. Sprays keep indefinitely and may be dried for winter bouquets. A very useful plant. 90 cts. for $3, \$ 2.50$ for $10, \$ 20$ per 100 .

*A. stelleriana. Old Woman; Dusty Miller; Beacb Wormwood. $2 \mathrm{ft}$. Attractive for its silvery, fine-cut foliage, which makes a splendid edging, especially when mixed with pinks or some Iow blue flower. 75 cts. for $3, \$ 2.20$ for $10, \$ 15$ per 100 .

A. vulgaris lactiflora. White Mugwort. 3 to $4 \mathrm{ft}$. August and September. Unlike the other varieties, which are grown for their foliage, this introduction from China bears sprays of creamy white flowers on tall, erect stems which are clothed with fine-cut, dark green foliage. It makes a splendid cut-flower for mixing with flowers of decided color or form, such as delphiniums. $\$ 1.05$ for $3, \$ 2.70$ for $10, \$ 20$ per 100 .

\section{ARUNCUS • Goatsbeard}

Aruncus sylvester. Common Goatsbeard. $4 \mathrm{ft}$. June. A bold, and highly ornamental perennial, resembling the astilbes but taller, and producing long, feathery plumes of white flowers. $\$ 1.05$ for $3, \$ 3$ for $10, \$ 20$ per 100.

\section{ASCLEPIAS - Milkweed}

Asclepias incarnata. Swamp Milkweed. 3 to $4 \mathrm{ft}$. July. Leafy and branching with nodding heads of showy purplish red flowers. The seed-pods are curiously owl-like and they are fascinating in winter. 90 cts. for 3, $\$ 2.40$ for 10 .

A. tuberosa. Butterfly Weed. 18 to 24 in. July to September. A handsome low, bushy plant, with heads of dazzling orange-colored flowers. Fine plant for naturalizing. $\$ 1.05$ for $3, \$ 2.70$ for $10, \$ 21$ per 100 .

\section{ASPERULA • Woodruff}

*Asperula odorata. Sweet Woodruff. 6 to 8 in. May. Erect little plants with fine-toothed leaves in clusters of eight, and heads of snowy white flowers. Increases rapidly and is used for carpeting shady places and for edgings. A fine scented herb. 90 cts. for $3, \$ 2.40$ for 10.

\section{ASPHODELINE • Jacob's-Rod}

Asphodeline lutea. Common Jacob's-Rod. A fine border plant, having tall spikes of very fragrant, bright yellow, Iily-like flowers and sword-like foliage.

\section{ASTER}

A very beautiful class of hardy plants, including a great variety of forms which vary a great deal in time of blooming, size of flowers, and stature. The dwarf, alpine species indicated below bloom early and are splendid decorative plants for either rockery or border. The tall, fall-blooming kinds, or Michaelmas Daisies, are descendants from the beautiful wild New England Aster so common in Massachusetts, and many other native species. 


\section{ASTERS, continued}

The Asters are 75 cts. for $3, \$ 2.20$ for $10, \$ 15$ per 100 except where noted otherwise

Aster acris. $1 \mathrm{ft}$. September. Large blue flowers with handsome Iong rays. Very showy.

*A. alpinus. Rock Aster. 6 to 9 in. Late May to June. Large, showy blue flowers, each on good stem for cutting. Desirable for rock garden or border.

*A. alpinus albus. 6 in. White flowers similar to the preceding.

*A. alpinus, Dark Beauty. 6 in. May and June. Large, dark violet-blue flowers.

*A. alpinus giganteus. 12 to $15 \mathrm{in.} \mathrm{Soft} \mathrm{blue} \mathrm{flowers}$ of unusually large size. A more robust plant than alpinus.

A. alpinus ruber. 6 in. to $1 \mathrm{ft}$. May and June. Bright reddish Iavender flowers.

*A. longifolius. Long-leaved Aster. 12 to 18 in Similar to Alpinus but larger and with broad leaves 3 to 5 inches long. Flowers are large and vary from violet to white.

A. amellus bessarabicus. Bessarabian Aster. 18 in. August. Showy dark, purplish blue flowers, with orange center. Good for cutting.

A. amellus elegans. 12 to 18 in. August. A fine free-blooming sort with bright bluish lilac flowers.

A. amellus roseus. 12 to 18 in. August. Rich purple-rose flowers, with golden centers. $90 \mathrm{cts}$. for 3 , $\$ 2.40$ for $10, \$ 18$ per 100 .

A. ericoides. Heath Aster. 18 in. October. Neat little plants with heath-like foliage and arching sprays of fairy-like white flowers with yellow centers. A small but elegant variety.

A., Japanese. $2 \mathrm{ft}$. An unnamed variety from Japan which is entirely distinct from all other hardy Asters. The symmetrical plants bear double white flowers something like the double white feverfew, from July to September. 90 cts. for 3, $\$ 2.40$ for 10 .

A. lævis. Smootb Aster. 3 to $4 \mathrm{ft}$. Early fall. Large blue flowers.

A., Mauve Cushion. 9 in. October and November. A cushion-like plant. The flowers are delicate mauve and are produced in great numbers. A recent importation from Japan and of unusual beauty. $90 \mathrm{cts}$. for $3, \$ 2.40$ for 10 . $\$ 18$ per 100 .

A. multiflorus. Wreath Aster. 18 in. Multitudes of small white flowers. A native which is happy in dry places.

A. novæ-angliæ. New England Aster. 3 to $5 \mathrm{ft}$ August and September. Our grandest American species which adorns our Massachusetts hills and fields everywhere, with thousands of large violetpurple flowers. One of the finest for mass effects

A. novæ-angliæ, Mrs. F. W. Raynor. $4 \mathrm{ft}$. Sep tember and October. Large flowers of an unusua shade of very dark rosy crimson. 90 cts. for 3 $\$ 2.40$ for 10 .

A. novæ-angliæ roseus. 3 to $4 \mathrm{ft}$. August and September. A charming variety of the above in all shades of rose-pink. Some think it the most beautiful of aII hardy Asters.

A. novæ-angliæ roseus superbus. 3 to $4 \mathrm{ft}$. August and September. An almost red form of the preceding, and a profuse bloomer. $\$ 1.20$ for 3 , $\$ 3.50$ for $10, \$ 24$ per 100 .

A. novi-belgi. New York Aster. 3 to $5 \mathrm{ft}$. September and October. Pale blue flowers of medium size One of the most distinct and beautiful. Excellent in shrubbery and border.

A. ptarmicoides. White Upland Aster. 18 in August and September. Produces a multitude of small white and sometimes faintly yellow flowers in flat sprays. Useful for cutting. The plant is bushy.

A. spectabilis, Nenco. Seaside Aster. $2 \mathrm{ft}$. A stout little plant with very large lavender-purple flowers. Does well near the coast. 90 cts. for $3, \$ 2.40$ for 10 $\$ 18$ per 100 .

A. tataricus. 5 to $6 \mathrm{ft}$. October to December A very tall variety with Iarge blue-violet flowers. The Iatest Aster to bloom.

\section{Named Hardy Asters}

The Aster family is almost endless, and European hybridizers have produced an amazing number of very beautiful forms, of which we offer the choicest. They abound in shades of Iavender, pink, and bluish purple, and produce an indescribably beautiful mass effect at the back of the border or at the edge of a shrubbery. They will thrive in poor soil, but to be seen at their best they should be weIl treated. They are worth it.

Abendroth. $5 \mathrm{ft}$. September and October. Bright rosy red flowers in great profusion. One of the best. 90 cts. for 3, $\$ 2.40$ for $10, \$ 18$ per 100 .

Anita Ballard. $41 / 2 \mathrm{ft}$. August and September. Very Iarge, pale, cornflower-blue, semi-double flower with incurved rays. $\$ 1.05$ for 3, \$3 for $10, \$ 21$ per 100 .

Beauty of Colwall. $4 \mathrm{ft}$. August and September. Charming double flowers of soft Iavender. $90 \mathrm{cts}$ for $3, \$ 2.40$ for $10, \$ 18$ per 100 .

Blue Gem. 4 to $5 \mathrm{ft}$. September and October. Very Iarge, double flowers of a glorious shade of rich dark blue. One of the handsomest ever introduced. $\$ 1.20$ for $3, \$ 3.50$ for $10, \$ 24$ per 100 .

Climax. $5 \mathrm{ft}$. August to October. One of the finest Asters, producing Iarge flowers (2 inches across) of clear light blue with golden central disk. $90 \mathrm{cts}$. for $3, \$ 2.40$ for $10, \$ 18$ per 100 .

Elta. 3 to $4 \mathrm{ft}$. October. Semi-double flowers of a handsome pale Iilac shade, which last weIl when cut. $\$ 1.20$ for $3, \$ 3.50$ for $10, \$ 24$ per 100 .

Feltham Blue. $2 \frac{1}{2}$ to $4 \mathrm{ft}$. August and September. A decorative, free-blooming variety with bright blue flowers, having yellow centers. 90 cts. for $3, \$ 2.40$ for $10, \$ 18$ per 100 .

Grey Lady. 3 to $4 \mathrm{ft}$. Large, semi-double flowers of a most exquisite shade of opal-gray, resembling small chrysanthemums. $\$ 1.20$ for $3, \$ 3.50$ for $10, \$ 24$ per 100.

King of the Belgians. $3 \mathrm{ft}$. September. Immense, semi-double, Iavender-blue flowers with bright golden centers. $\$ 1.20$ for $3, \$ 3.50$ for $10, \$ 24$ per 100 .

Lady Lloyd. 3 to $4 \mathrm{ft}$. August and September. A very beautiful variety with large heads of clear rosepink flowers. 90 cts. for $3, \$ 2.40$ for $10, \$ 18$ per 100 .

Lady Trevellyn. 3 to $4 \mathrm{ft}$. Immense heads of white flowers with yellow centers. Most conspicuous and ornamental.

Mme. Emile Thoury. $3 \mathrm{ft}$. August. Profuse bloomer; flowers light ageratum-blue. Earlier than Climax. $\$ 1.20$ for $3, \$ 3.50$ for $10, \$ 24$ per 100 .

Peggy Ballard. $3 \mathrm{ft}$. Large, pyramidal sprays of double rosy mauve flowers on compact plants. A fine thing. 90 cts. for $3, \$ 2.40$ for $10, \$ 18$ per 100 .

Perry's Favorite. 18 to 24 in. A very showy variety with erect, bright reddish pink flowers of medium size. 90 cts. for $3, \$ 2.40$ for $10, \$ 18$ per 100 .

Perry's White. $2 \mathrm{ft}$. August and September. White flowers over $2 \frac{1}{2}$ inches across, with a golden disk that turns to rich maroon.

Queen Mary. 3 to $4 \mathrm{ft}$. Enormous rich blue flowers in Iarge, conical trusses. A new sort of great merit, much praised abroad. $\$ 1.20$ for $3, \$ 3.50$ for $10, \$ 25$ per 100.

Sam Banham. 3 to $4 \mathrm{ft}$. August. Long, feathery sprays of large, pure white flowers. $\$ 1.20$ for 3 , $\$ 3.50$ for $10, \$ 24$ per 100 .

Snowflake. 24 in. August and September. Flowers snow-white. Fine.

St. Egwin. 18 to 24 in. September and October. A charming bright pink Aster produced on strong, symmetrical plants. 90 cts. for $3, \$ 2.40$ for $10, \$ 18$ per 100.

Thomas Ware. 3 to $4 \mathrm{ft}$. Late. Effective delicate pink flowers. Very dense habit.

White Climax. $5 \mathrm{ft}$. August. A pure white form of the ever-popular Climax. 90 cts. for $3, \$ 2.40$ for 10 , $\$ 18$ per 100.

Ypres. 12 to 18 in. Neat, compact bushy plants with profuse clusters of rosy red flowers. $\$ 1.05$ for 3 , $\$ 2.70$ for $10, \$ 20$ per 100 . 


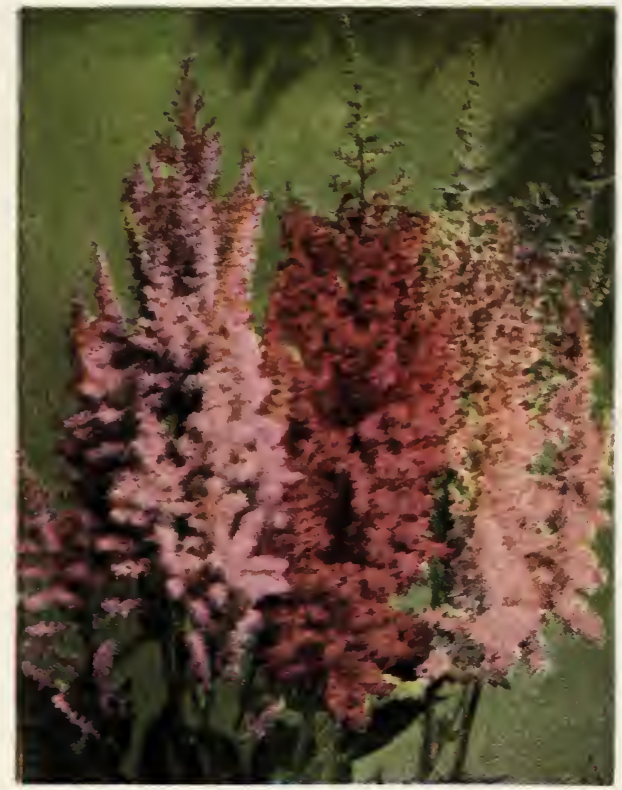

Astilbes: Gloria, Salland, Queen Alexandra

\section{ASTILBE}

The fluffy plumes of the Astilbes have an airiness and a laciness about them unequaled by any perennial of similar habit. They are not very common in gardens, although they succeed weIl in ordinary soil, and even in partial shade if they are given plenty of water during the growing and flowering season. They are most familiar as pot plants from the florists, who usually call them "Spireas," which they are not.

They have an indescribable beauty when used as an edging to a border of shrubs or evergreens, and the many varieties shade into each other in delicate tints of white, cream, pink and rose. We recommend them highly.

Astilbe arendsi. This is a horticultural name given to a number of hybrids of $A$. davidi, all of exquisite beauty, and of which a representative collection follows:

America. A charming, pale pink, medium tall variety which is much used for early forcing. 50 cts. each, \$4 for $10, \$ 30$ per 100.

Betsy Cupereus. $5 \mathrm{ft}$. Stout, well-filled spikes, tipped with drooping sprays of pure white flowers dotted with pink in the center. 60 cts. each, \$5 for 10.

Ceres. $21 / 2$ to $3 \mathrm{ft}$. Last of July to August. Wellbranched panicles of brilliant rosy lilac flowers. 50 cts. each, $\$ 4$ for 10 .

Crepuscule. $2 \frac{1}{2}$ to $3 \mathrm{ft}$. Flesh-colored flowers in large sprays. $50 \mathrm{cts}$. each, $\$ 4$ for 10.

Feerie. 18 to 24 in. Very handsome panicles of pale flesh-white flowers of great delicacy and charm. 50 cts. each, $\$ 4.50$ for 10 .

Gerbe d'Argent. 2 to $3 \mathrm{ft}$. The big sprays of almost pure white flowers are most handsome. 50 cts. each, \$4 for 10, \$30 per 100.

Gloria. $2 \mathrm{ft}$. July and August. Compact dwarf plants with dense, plumy sprays of deep pink flowers. 40 cts. each, \$3.50 for $10, \$ 25$ per 100 .

Juno. $3 \mathrm{ft}$. Plumes rich violet-rose. $50 \mathrm{cts}$. each, $\$ 4$ for $10, \$ 30$ per 100 .

Marguerite van Rechteren. $5 \mathrm{ft}$. August. A handsome, tall sort with fringy red flowers tinted with Iilac. 60 cts. each, $\$ 5$ for 10 .

\section{ASTILBE, continued}

Meta Immink. $3 \mathrm{ft}$. Deep pink flowers in dense plumes. 50 cts. each, $\$ 4$ for $10, \$ 30$ per 100.

Moerheim. $4 \mathrm{ft}$. Its well-branched, erect spikes of flowers have a length of over 2 feet and are pure white. 50 cts. each, \$4 for 10.

Pyramidal. 2 to $3 \mathrm{ft}$. Very fine panicles of pure milky white. 50 cts. each, $\$ 4$ for $10, \$ 30$ per 100 . Rose Pearl. 21/2 ft. July and August. Shell-pink flowers of a very delicate and appealing shade. 40 cts. each, $\$ 3.50$ for $10, \$ 30$ per 100

Salland. $6 \mathrm{ft}$. Gigantic feathery sprays of rich red flowers. 50 cts. each, $\$ 4$ for $10, \$ 30$ per 100 .

Vesta. $3 \mathrm{ft}$. Very graceful plumes of light mauve and Iilac. 40 cts. each, $\$ 3.50$ for $10, \$ 30$ per 100 .

A. astilboides. Goatsbeard Astilbe. 2 to $3 \mathrm{ft}$. The erect branching panicles are crowded with dense clusters of white flowers. 35 cts. each, $\$ 2.70$ for $10, \$ 20$ per 100 .

A. chinensis. Cbinese Astilbe. 18 in. July and August. Finely cut foliage. Pink flowers in fine sprays which are effective in masses and in the border. 35 cts. each, $\$ 2.70$ for $10, \$ 20$ per 100 .

A. davidi. David Astilbe. July and August. The flower-spikes are 5 feet high, like a gigantic Astilbe japonica, of lovely pink. $50 \mathrm{cts}$. each, $\$ 4$ for 10 .

A. japonica. Japanese Astilbe. $1 \mathrm{ft}$. June and July. Its plume-like spikes of pure white flowers and pretty dark green foliage make this a valuable sort for shady places in the garden or forcing. $35 \mathrm{cts}$. each, $\$ 2.70$ for 10 , \$20 per 100 .

A. japonica, Peach Blossom. 15 to $18 \mathrm{in.} \mathrm{July} \mathrm{and}$ August. Soft pink flowers. 40 cts. each, $\$ 3.50$ for 10 , $\$ 27$ per 100.

A. japonica, Queen Alexandra. $2 \mathrm{ft}$. A very fine early-flowering variety of soft creamy pink color. 40 cts. each, $\$ 3.50$ for 10 , \$24 per 100 .

A. japonica, W. E. Gladstone. $2 \mathrm{ft}$. Similar to Queen Alexandra, but has feathery plumes of pure white flowers. 50 cts. each, $\$ 4$ for $10, \$ 30$ per 100 .

\section{AUBRIETIA}

Charming little plants closely related to the Alyssum tribe and used for the same purpose, providing a wide range of purple, violet, and pink shades in ideal plants for rockwork or edging.

*Aubrietia deltoidea. Common Aubrietia. 3 to 4 in April and May. Small, showy purple flowers which almost hide the silvery foliage, making a closely woven mat between rocks and along edges of borders. $\$ 1.05$ for $3, \$ 2.70$ for $10, \$ 20$ per 100 .

*A. deltoidea bougainvillei. Bougainville Aubrietia. 4 in. A more compact little plant than the foregoing, with flowers of light violet. $\$ 1.05$ for $3, \$ 2.70$ for $10, \$ 20$ per 100 .

*A. deltoidea græca. Greek Aubrietia. 3 to 4 in. May. A rock plant of trailing habit, thickly covered with dark violet flowers larger than other Aubrietias. $\$ 1.05$ for $3, \$ 2.70$ for $10, \$ 20$ per 100 .

*A. deltoidea purpurea. Purple Lady Aubrietia. 4 to 5 in. Large, purple flowers and a more erect growth. $\$ 1.05$ for $3, \$ 2.70$ for $10, \$ 20$ per 100 .

\section{BAPTISIA • Wild Indigo}

Baptisia australis. Blue Wild Indigo. 2 to $3 \mathrm{ft}$. Late May and June. A handsome plant, with deep blue, Iupine-like flowers in long, curving racemes. Easily cultivated and adapted to any garden soil.

B. tinctoria. Yellow Wild Indigo. 2 to $3 \mathrm{ft}$. July. A bushy plant with dark green, deeply cut foliage and showy spikes of bright yellow flowers. $75 \mathrm{cts}$. for $3, \$ 2.20$ for $10, \$ 15$ per 100 .

\section{BELAMCANDA - Blackberry Lily}

Belamcanda chinensis. Blackberry Lily. 2 to $3 \mathrm{ft}$. July and August. A Ioosely formed, iris-like plant with slender, much branched stems bearing bright orange-yellow, lily-like flowers, spotted with brown. 


\section{BELLIS • English Daisy}

The true Daisies make dense rosettes of dark green leaves and bloom profusely early in the spring. They are especially charming edging plants and do well in half-shady places in the rockery. They must be kept dry in winter and should have slight protection. Bellis perennis. Englisb Daisy. April to June. 3 to 6 in. Densely double flowers of rosy red, white, and pink. 75 cts. for $3, \$ 2.20$ for $10, \$ 15$ per 100 .

$*$ B. perennis, Giant White. A Iarger flowered type. This variety and the next, when mixed with forgetme-nots, make a lovely edging. 75 cts. for $3, \$ 2.20$ for $10, \$ 15$ per 100 .

*B. perennis, Giant Pink. A pink form of the preceding. 75 cts. for $3, \$ 2.20$ for $10, \$ 15$ per 100 .

\section{BOCCONIA • Plume Poppy}

Bocconia cordata. Pink Plume Poppy. 5 to $8 \mathrm{ft}$. JuIy and August. A big, Iusty plant with Iarge, ruffled foliage and nodding clusters of creamy flowers which are followed by grayish seeds that make a pleasant rattle in the wind. Good in wild garden or shrubbery and for subtropical effects. 75 cts. for 3 , $\$ 2.20$ for $10, \$ 15$ per 100 .

\section{BOLTONIA}

A group of plants closely related to the hardy asters and useful for the same purposes. Their stems are stiffer and wirier, requiring less support. They are very easy to grow and take care of themselves when once established.

Boltonia asteroides. Wbite Boltonia. 5 to $6 \mathrm{ft}$. September and October. Branching stems, bearing numerous aster-Iike white flowers. One of the best Iate-flowering perennials. 75 cts. for $3, \$ 2.20$ for 10 , $\$ 15$ per 100.

B. latisquama. Violet Boltonia. $4 \mathrm{ft}$. July to October. A handsome plant with Iarge showy heads of pale Iilac-purple flowers. Especially good for cutting and an attractive plant in rough places and in the border. 75 cts. for $3, \$ 2.20$ for $10, \$ 15$ per 100 .

B. latisquama nana. Dwarf Pink-rayed Boltonia. $2 \mathrm{ft}$. Similar to the foregoing but dwarfer and has beautiful pink flowers.

B. lævigata. 6 to $7 \mathrm{ft}$. October. Flowers are pink, fading to white and borne in great profusion. A strong-growing plant for the middle or back of the border. 75 cts. for $3, \$ 2.20$ for $10, \$ 15$ per 100 .

\section{BUPHTHALMUM - Oxeye}

Buphthalmum salicifolium. Willowleaf Oxeye. $11 / 2 \mathrm{ft}$. June and JuIy. A showy garden plant of compact habit, with a profusion of flowers like big, clear yeIlow daisies. $\$ 1.05$ for $3, \$ 2.70$ for $10, \$ 20$ per 100.

B. speciosum. Heart-leaved Oxeye. 3 to $4 \mathrm{ft}$. June and JuIy. A much Iarger plant than the preceding, with very big, heart-shaped leaves and Iarge, yellow flowers. It grows very thickly and makes splendid masses. $\$ 1.05$ for $3, \$ 2.70$ for $10, \$ 20$ per 100 .

\section{CALIMERIS}

Calimeris incisa. Starwort. 1 to $2 \mathrm{ft}$. JuIy and August. A plant of easy culture in any good soil. Similar to the hardy asters and makes a brave display of Iarge, purple-rayed flowers shading to pale lavender with yellow centers.

\section{CALTHA}

Caltha palustris. Marsb Marigold. $1 \mathrm{ft}$. May and June. A cheerful little plant for marshy places and by the sides of streams and ponds. Flowers bright yellow and look like clusters of big buttercups.

\section{CAMPANULA • Bellflower}

No one interested in rock gardening can afford to pass by the Bellflowers, and perennial borders rely upon them for some of their finest effects. They form a very large and much-varied family, containing plants of absorbing interest and beauty for every purpose. The taller sorts are indispensable for handsome garden effects, and the dwarfer types are equally at home in the rockery or at the edge of garden beds.

*Campanula alliariæfolia. $11 / 2$ to $2 \mathrm{ft}$. July. Erect, pyramidal plants of vigorous habit. Flowers beIIlike, white, fringed at the edge, 2 inches long. $\$ 1.20$ for $3, \$ 3.50$ for 10 .

*C. carpatica. Carpatbian Bellflower. A pretty species, growing in compact tufts not exceeding 8 inches high. Flowers clear blue, held erect on wiry stems. It begins blooming in June, continuing until October. As an edging for a hardy border or for the rockery, it is unsurpassed.

*C. carpatica alba. Wbite Carpatbian Bellflower. 9 in. or more. June to September. A pure, glistening white-flowered variety, almost indispensable in the rock garden. Prettier than the blue variety, of which it is a variation, and the appearance of which is much improved when the white variety is pIanted with it.

*C. carpatica turbinata. Top Bellflower. $2 \mathrm{ft}$. June. Rich purple flowers of top-shape and Iarger than the above. $\$ 1.05$ for $3, \$ 2.70$ for 10 .

*C. carpatica turbinata alba. Wbite Top Bellflower. Similar to the one above, but has white flowers. $\$ 1.05$ for 3, $\$ 2.70$ for 10 .

*C. garganica. Gargano Harebell. 3 to 4 in. A gem for the rock garden. Forms a low, spreading tuft which in June is covered with starry, light blue flowers having a white eye. Exquisite hanging over a rock. $\$ 1.05$ for $3, \$ 2.70$ for $10, \$ 24$ per 100 .

*C. glomerata dahurica. Daburian Bellflower. 11/2 to $2 \mathrm{ft}$. June and July. A splendid form bearing rich purple flowers in clusters on the ends of the shoots. Especially good for cutting. $\$ 1.05$ for 3 , $\$ 2.70$ for $10, \$ 20$ per 100 .

C. glomerata superba. Sbowy Cluster Bellflower. $21 / 2 \mathrm{ft}$. June and JuIy. Large clusters of violetblue flowers. 90 cts. for $3, \$ 2.40$ for 10 .

*C. lactiflora. Milky Bellflower. $2 \mathrm{ft}$. July and August. One of the best Campanulas and finest of perennials. Wonderful blue flowers and blooms over a long period.

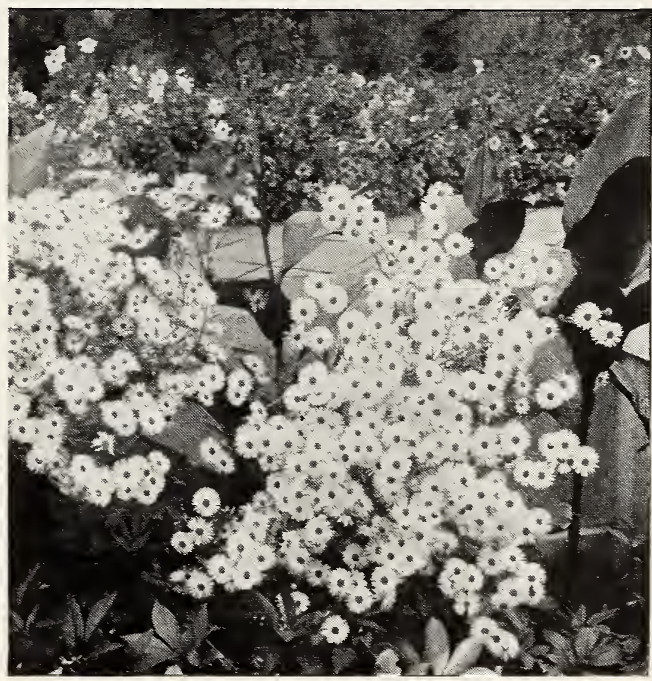

Boltonia latisquama. Splendid for cutting

Except where otherwise indicated, all Perennials are $90 \mathrm{cts}$. for $3, \$ 2.40$ for $10, \$ 18$ per 100 
CAMPANULA, continued

C. latifolia macrantha. Royal Bellflower. $3 \mathrm{ft}$. June and July. Very handsome, enormous drooping bells of fine satiny lilac and deep purplish shades in splendid spikes. Similar to but larger than the preceding variety.

*C. latiloba (grandis). Olympic Bellflower. $11 / 2 \mathrm{ft}$. May and June. Very showy, Iarge, saucer-shaped flowers of rich violet-blue often 2 inches across.

C. latiloba alba. A charming form of the above. C. medium. Canterbury Bells. 2 to $3 \mathrm{ft}$. Late June and July. Very large, bell-shaped flowers of blue, white, pink, and mixed. This is, perhaps, the most delicately beautiful of all. The white and pink kinds are especially lovely. Colors separate or mixed as desired.

C. medium calycanthema. Cup-and-Saucer Bellflower. 2 to $3 \mathrm{ft}$. July. The enlarged calyx is of the same color and texture as the flower, giving a cup-and-saucer effect. Pink, Blue, White, and Mixed. Sold in separate colors or mixed, as desired.

C. muralis (C. portenscblagiana). 6 to 9 in. A profuse, blue-flowering trailer similar to $C$. garganica but with differently shaped flowers. $\$ 1.05$ for 3 . $\$ 2.70$ for $10, \$ 24$ per 100 .

C. persicifolia. Peacbleaf Bellflower. 2 to $3 \mathrm{ft}$. June and July. Broad, single, blue, bell-shaped flowers arranged along a tall flower-spike. One of the most desirable border plants.

C. persicifolia alba. White Peacbleaf Bellflower. Similar to the above, but has white flowers.

C. persicifolia, Feltham Beauty. $3 \mathrm{ft}$. June, July. A delightful new variety with large, single bells of soft, light blue. Most attractive. $\$ 1.05$ for 3, $\$ 3$ for $10, \$ 24$ per 100 .

C. persicifolia moerheimi. Moerbeim Bellflower. $2 \mathrm{ft}$. June and July. A handsome plant of free, sturdy habit, with large, pure white, semi-double flowers, borne on a stiff, erect flower-stalk. An excellent variety.

\section{CAMPANULA, continued}

C. pulcherrima. $2 \mathrm{ft}$. July. A variety with numerous small blue bells. 75 cts. for $3, \$ 2.20$ for 10 , $\$ 15$ per 100.

C. punctata. Spotted Bellflower. $1 \mathrm{ft}$. A very pretty little plant, quite hairy, with large whitish flowers spotted with purple inside. One of the most interesting of the whole family.

C. pyramidalis. Cbimney Bellflower. 4 to $6 \mathrm{ft}$. July and August. Forms a pyramid composed of numerous stems, crowded with large, handsome: blue, salver-shaped flowers. This is undoubtedly the choicest variety of Bellflowers. $\$ 1.05$ for $3, \$ 2.70$ for $10, \$ 20$ per 100 .

C. pyramidalis alba. White Cbimney Bellflower. Similar to the above, but has white flowers. $\$ 1.05$ for $3, \$ 2.70$ for $10, \$ 20$ per 100 .

*C. rotundifolia. Harebell. $1 \mathrm{ft}$. June to August. In the wild it is more slender and taller than in the garden. Clear blue flowers. Especially suited for crevices in the rock garden or steep slopes, where it can show its pendent habit. This is the true Bluebell of Scotland.

*C. trachelium. Coventry Bells. 2 to $3 \mathrm{ft}$. July and August. Sturdy, hairy plant, with drooping, light purple, somewhat downy flowers.

\section{CAREX - Sedge}

*Carex morrowi variegata. Silver-edged Morrow Sedge. $1 \mathrm{ft}$. A handsome, grass-like plant suited for the border. The stiff, clean, white-edged foliage keeps in condition for months. Perfectly hardy, holding its foliage all winter. $\$ 1.05$ for $3, \$ 3$ for 10 .

\section{CASSIA}

Cassia marilandica. Wild Senna. 3 to $4 \mathrm{ft}$. June to September. A splendid border plant with bright yellow flowers in clusters at the tops of the stems. Fine light green foliage. Good for planting among shrubbery.

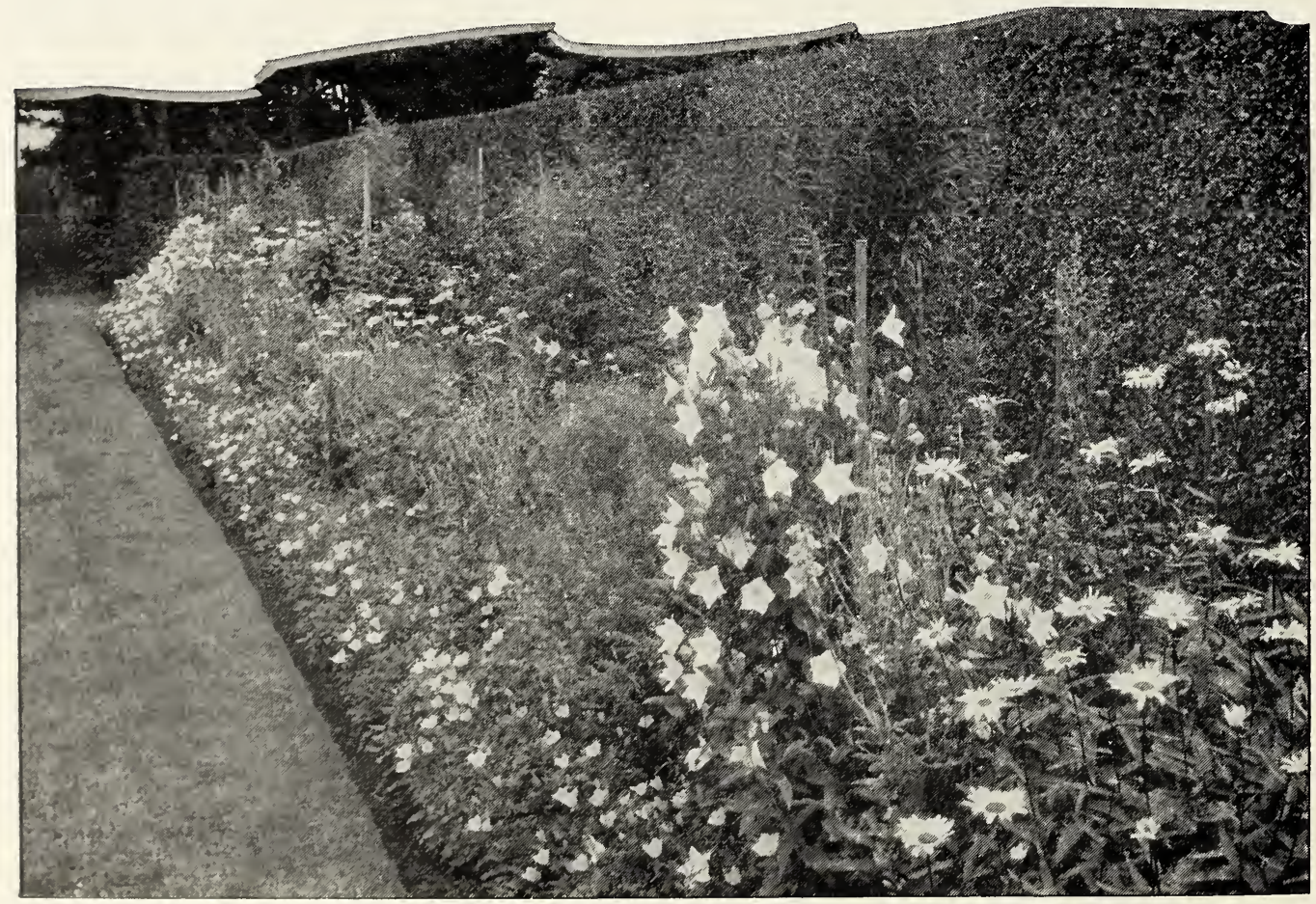

Campanula carpatica used as an edging to a perennial border planting 


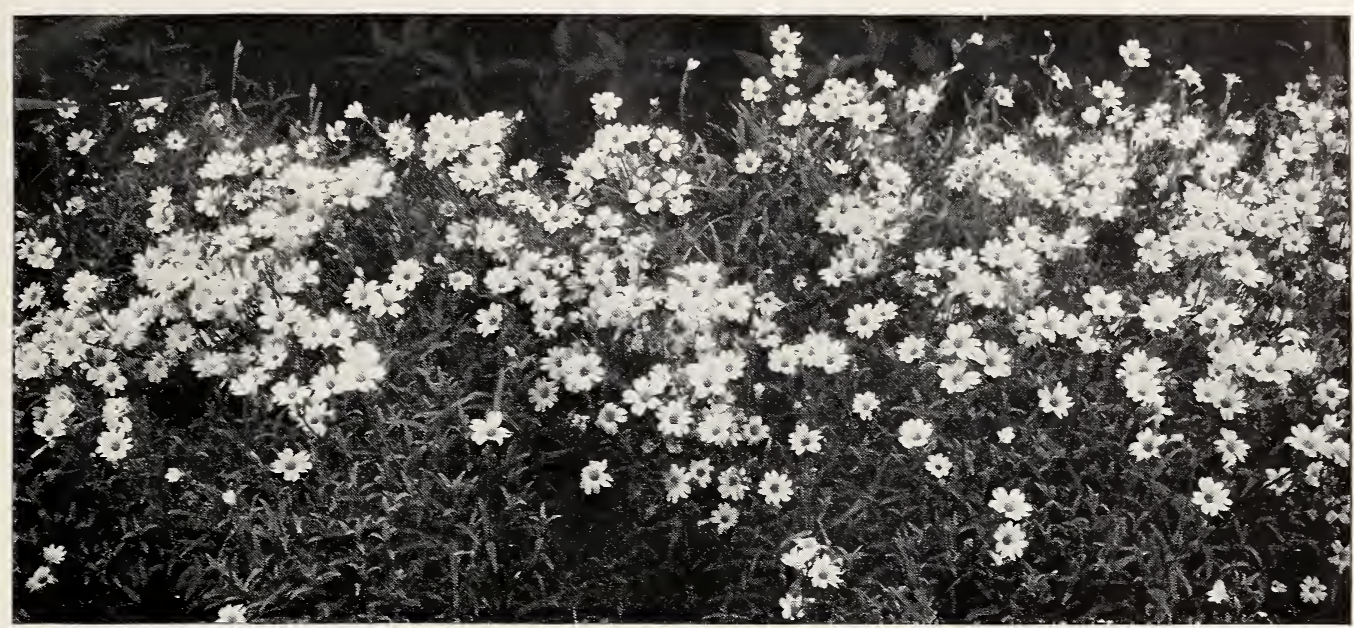

Cerastium tomentosum. A delightful edging or rock plant

\section{CATANANCHE - Cupids-Dart}

Catananche cærulea. Blue Cupids-Dart. 1 to $2 \mathrm{ft}$. July and August. Heads of pretty, deep blue, daisylike flowers on long stems. An everlasting. An oIdfashioned herb once famed as the chief ingredient of witch's love-philter.

C. cærulea alba, White Cupids-Dart. A white form

\section{CEDRONELLA}

*Cedronella cana. Hoary Cedronella. 12 to 18 in. July to October. A fine aromatic herb with purplecrimson flowers borne in whorls on Iong spikes. $\$ 1.05$ for 3, \$2.70 for 10 , \$21 per 100 .

\section{CENTAUREA}

The Centaureas are bold flowering plants, with graceful, fluffy flowers resembling thistle-blossoms. They bloom over a long season and are especially useful for cutting.

* Centaurea dealbata. Persian Centaurea. 15 to 24 in. June to August. Large, rosy pink flowers on Ieafy stems, rising from a cluster of very Iarge, bold foliage.

C. macrocephala. Globe Centaurea. $3 \mathrm{ft}$. July to September. Perhaps the most showy Centaurea with enormous flowers of rich golden yellow. UsefuI for cutting.

*C. montana. Mountain Bluet. 20 in. July and August. A low, bushy plant with big bluish violet
flowers, like enormous cornflowers. Valuable for cutting and very effective in the border mixed with pale pink, yellow, or white flowers.

*C. montana alba. Wbite Mountain Bluet. A white form of the above. 9 to 15 in. June.

\section{CENTRANTHUS • Jupitersbeard}

Centranthus ruber. Jupitersbeard. $3 \mathrm{ft}$. June and July. The old-fashioned garden variety, called "Red Valerian," with many crimson and light red flowers produced steadily through the summer. A fine old flower, much neglected nowadays, which ought to be better known.

C. ruber albus. Wbite Jupitersbeard. A white form of the above.

C. ruber roseus. Pink Jupitersbeard. $2 \mathrm{ft}$. July. A rare and attractive pink-flowering type, like the preceding in other respects.

\section{CEPHALARIA}

Cephalaria tatarica. Tatarian Cepbalaria. $6 \mathrm{ft}$. July and August. Flat heads of showy cream-white flowers on good stems for cutting. Suited for rear of border, where bold and striking effects are desired. 75 cts. for $3, \$ 2.20$ for 10 , \$15 per 100 .

\section{CERASTIUM}

*Cerastium argenteum (C. grandiflorum). 6 to 8 in. Silvery gray foliage and white, almost transparent, flowers. Plant creeping and suitable for rockwork. $\$ 1.20$ for 3, \$3.50 for 10, \$27 per 100.

*C. biebersteini. Taurus Cerastium. 6 in. May and June. A creeping pIant with white flowers and woolly, dark green foliage.

*C. tomentosum. Snow-in-Summer. 3 to 6 in. May and June. Spreading plant with silvery foliage covered with a sheet of smaII white flowers. Used principally for edging and rockwork. It is especially good in the corners of stone steps and its gray foliage looks well with low pink flowers. 75 cts. for 3, \$2.20 for $10, \$ 15$ per 100 .

\section{CERATOSTIGMA}

*Ceratostigma plumbaginoides. Larpente Plumbago. One of the most desirabie border and rock plants. It is of dwarf, spreading habit, growing 6 to 8 inches high, covered with deep blue flowers during summer and fall. Comes up very late in spring so the ground should not be disturbed until it appears. $\$ 1.05$ for 3, \$2.70 for $10, \$ 21$ per 100 .

\section{CHEIRANTHUS}

*Cheiranthus allioni. Wallflower. 6 to 12 in. May to July. Small plants, with erect stems crowned by flat heads of dazzling orange-yellow flowers. One of the finest plants for massing or edging. A very peculiar, modernistic color combination is to plant it with pale blue forget-me-nots. It also looks exceedingly weII with dark purple, not violet flowers; white is not very good with it.

\section{CHELONE - Turtlehead}

Chelone glabra. White Turtlebead. $2 \mathrm{ft}$. July and August. Spikes of curiously shaped creamy white flowers. Does best in moist soil and likes some shade.

C. Iyoni. Pink Turtlebead. 2 to $3 \mathrm{ft}$. August and September. Produces rosy purple flowers in profusion. Foliage dark glossy green. It prefers a moist, half-shady situation. 


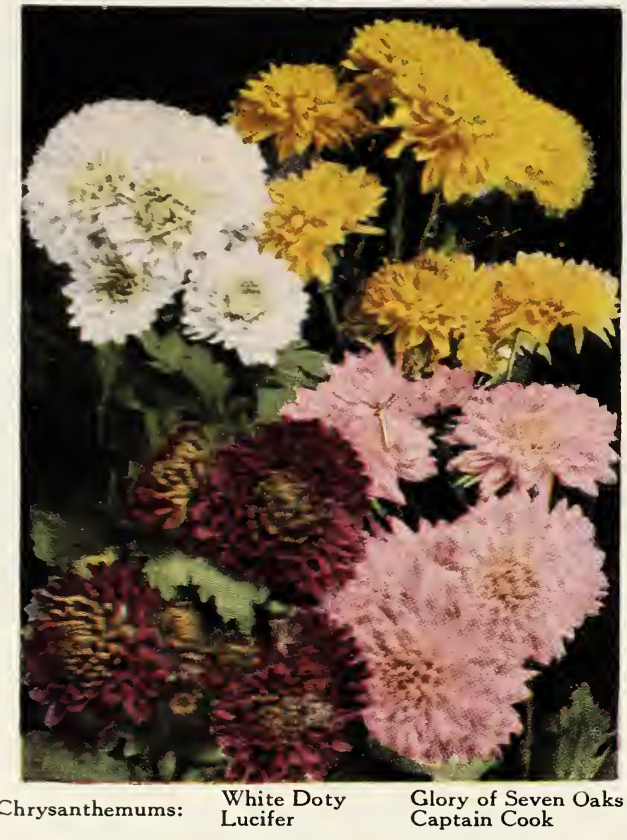

\section{CHRYSANTHEMUM}

Under this name we find many of the daisy-like flowers referred to as Shasta Daisies, Arctic Daisies, Marguerites, Pyrethrums, and others, as weIl as the typical fall-blooming Chrysanthemums which are so useful for late color in the garden. AII of them are of the easiest culture, thriving even under abuse, but they repay careful attention. Certainly no garden is complete without an adequate representation of this marvelous family of flowers.

*Chrysanthemum arcticum. Arctic Chrysanthemum. $11 / 2 \mathrm{ft}$. September and October. This charming plant forms an attractive rosette of dark green foliage, covered in September with multitudes of blush-white, daisy-like flowers from 2 to $2 \frac{1}{2}$ inches in diameter.

C. coccineum. See Pyrethrum at end of Chrysanthemum list.

C. coreanum. Korean Chrysanthemum. 2 to $3 \mathrm{ft}$. September and October. A superb garden plant, coming into bloom before the frrst frosts. Flowers are single, 2 to 3 inches across, white at first, acquiring a rose-pink tinge with age. Showy in masses and charming when cut. $\$ 1.05$ for $3, \$ 2.70$ for $10, \$ 20$ per 100 .

C. maximum, Alaska. $2 \mathrm{ft}$. AII summer. Large white flowers which are splendid for cutting and much used by the florists.

C. maximum, Burbank's Frilled. $21 / 2 \mathrm{ft}$. A gorgeous new variety. produced by the creator of the original Shasta Daisy. The Iarge, white flowers have great substance and are beautifully undulated and frilled. The stock is scarce and in great demand. At the Harvard Botanic Garden, in Cambridge, it has been tremendously admired, and everyone who has seen it has demanded plants at once. We have watched it in our nursery with increasing enthusiasm from year to year and believe it is superior to existing varieties in size, floriferousness, habit, and form of flower. Strong plants, $75 \mathrm{cts}$. each.

C. maximum, King Edward. $3 \mathrm{ft}$. July to October. New. One of the largest and finest varieties, producing Marguerite-like flowers of glistening white. C. maximum, Triumph. 2 to $3 \mathrm{ft}$. Gigantic white flowers 4 inches across, on very long stems. Very showy.

\section{CHRYSANTHEMUM, continued}

C. maximum, Shasta Daisy. $21 / 2 \mathrm{ft}$. One of the handsomest and hardiest. Remarkable for its gracefulness and the pure whiteness of its extremely large flowers which are desirable for cutting. 75 cts. for 3 , $\$ 2.20$ for $10, \$ 15$ per 100 .

C. maximum, The Speaker. $21 / 2 \mathrm{ft}$. July to October. A new variety which has extremely large, ivorywhite flowers nearly 6 inches in diameter. $\$ 1.05$ for $3, \$ 2.70$ for $10, \$ 20$ per 100 .

C. uliginosum. Giant Daisy. 4 to $5 \mathrm{ft}$. July to September. A fine, tall-growing variety, bearing a profusion of Iarge, pure white flowers with yellow centers; foliage light green. Desirable for shrubbery border. 75 cts. for $3, \$ 2.20$ for $10, \$ 15$ per 100 .

\section{Named Hardy Chrysanthemums}

Late in autumn, in the midst of frosts and freezes, these Hardy Chrysanthemums make the garden gay with color. They should be planted most generously in order to provide a brave display, for they are almost the only things in bloom at their season. They may be inter-planted with earlier flowers, or moved in to follow such things as Canterbury bells. A very successful way of handling them is to grow them all summer in an out-of-the-way place-a nursery or even in the vegetable-gardenand move them to the places where they are to flower when the ground is cleared of other plants. They may be moved when in full bloom without interfering with their beauty, and live on from year to year, spreading rapidly, but should have a light covering after the ground has frozen.

Except where noted, all named Hardy Chrysanthemums are $90 \mathrm{cts}$. for 3 of one kind, $\$ 2.40$ for 10 of one kind ( 5 of one kind sold at this rate), $\$ 18$ per 100 of one kind ( 25 of one kind sold at this rate). Do not order less than 3 of one kind. We cannot furnish 10 plants of 10 varieties for $\$ 2.40$.

Aberdeen. Pompon. Flowers of bright maroon.

Autumn Glow. Large flowers of rosy crimson.

Baby Marguerite. Button. Pure white.

Barbara Cumming. Single. Large, semi-double, decorative flowers, 3 inches across, clear yellow shading to orange-brown at center. August to October. New and very fine. $50 \mathrm{cts}$. each, $\$ 4$ for 10 .

Boston. Pompon. October and November. Golden bronze flowers with open center; tall and bushy.

Brutus. Pompon. Flowers of old-gold.

Captain Cook. Pompon. October and November. Dark rose.

Eve. October. Large flowers of rich, deep pink.

Excelsior. October. Large, single flowers of bronzy yellow

Field of Snow. Button. White, tinged pink.

Glory of Seven Oaks. Large flowers. September and October. Golden yellow. One of the best.

Golden Pheasant. Pompon. Orange-yellow.

Gypsy Girl. Single. Large flowers with a double row of petals. Bright crimson shaded with chestnutbrown. Begins blooming in early October and continues through the frosts. A new and dependable variety. 50 cts. each, $\$ 4$ for 10 .

Hilda Wells. Late blooming, producing fine single flowers of brownish red, yellow at base.

James Boone. Pompon. Late. Pure white flowers in profuse sprays.

Julie Lagravere. Pompon. November. Rich velvety maroon.

Lucifer. Early, shaggy flowers of star-form. Deep ox-blood-red of great depth and brilliance.

Mrs. Albert Phillips. Single. Early October. Beautiful rosy pink and cream blooms. Very lovely.

Oconto. Large flowers. October. Splendid pure white.

October Girl. Single. Medium size, semi-double flowers 2 inches across. Clear rose-pink turning to lavender. Blooms very early (October 1 ) and is very prolific and bushy. New and very desirable. $50 \mathrm{cts}$. each, $\$ 4$ for 10. 


\section{COREOPSIS, continued}

and are invaluable for maintaining continuous color and life in the garden.

Coreopsis delphinifolia. Larkspur Coreopsis. $2 \mathrm{ft}$. July to September. Deeply cut foliage and yellow flowers with dark brown disk. 75 cts. for 3, $\$ 2.20$ for $10, \$ 15$ per 100 .

C. grandiflora. Big Coreopsis. 2 to $3 \mathrm{ft}$. May to November. Very Iarge, golden yellow flowers. Superb for cutting. 75 cts. for $3, \$ 2.20$ for 10 , $\$ 15$ per 100.

C. lanceolata. Lance Coreopsis. $2 \mathrm{ft}$. June to September. Large, cosmos-like flowers of pure yellow. An excellent showy garden plant and beautiful when cut. 75 cts. for $3, \$ 2.20$ for $10, \$ 15$ per i00.

*C. rosea. Rose Coreopsis. $1 \mathrm{ft}$. July and August. Beautiful rosy pink flowers, with yellow centers. A fine rock plant. 75 cts. for $3, \$ 2.20$ for $10, \$ 15$ per 100.

C. verticillata. Tbreadleaf Coreopsis. $11 / 2$ to $2 \mathrm{ft}$. June to September. A pretty variety with narrow, dark green foliage and small, lemon-yellow flowers. $75 \mathrm{cts}$. for $3, \$ 2.20$ for $10, \$ 15$ per 100 .

\section{CORONILLA}

*Coronilla varia. Crownvetch. 1 to $2 \mathrm{ft}$. June to October. A trailing plant with showy pink, peashaped flowers. Fine for covering rough banks and ledges.

\section{COTULA}

* Cotula squalida. 1 to 2 in. A flat, creeping little plant from New Zealand, with dark green, very finely divided leaves somewhat like those of Acbillea tomentosa. White flowers like tiny daisies on short, erect stems. An excellent rock plant for crevices and carpeting. It likes moisture and full sun, although it does not insist upon them. Grows quickly and soon forms a dense green carpet. Rare. S1 each, $\$ 8$ for 10 .

\section{CYNANCHUM}

Cynanchum acuminatifolium. Mosquito-trap. $1 \mathrm{ft}$. July. A plant with attractive, neat foliage and pretty glossy white flowers that resemble lilies-of-the-valley

\section{CYPRIPEDIUM}

Cypripedium acaule. Pink Ladyslipper. 8 to 12 in. May, June. A hardy native Orchid, with curious pocket-like flowers of vinous pink. It does best in a dry, sourish soil in open places in the woods, or in a half-shady border. From 4-in. pots.

C. pubescens. Yellow Ladyslipper. 1 to $2 \mathrm{ft}$. May, June. TalI, leafy stems surmounted by yellow, saclike flowers stained brown. Very beautiful and long-lasting. Likes moist, sour soil in a shady place. $\$ 1.05$ for $3, \$ 3$ for 10

C. spectabile. Sbowy Ladyslipper. 1 to $3 \mathrm{ft}$. June. The largest and handsomest of our native Orchids. The large-pouched flowers are pale pink or white, stained with crimson, and last for many days. Not hard to grow if given damp, sour soil and either dense or partial shade. $\$ 1.05$ for $3, \$ 3$ for 10 .

\section{DELPHINIUM · Larkspur}

More and more we rely upon the Hardy Larkspurs for the wonderful tints and shades of blue, lavender, and purple which they provide. Incredible improvements have been made in the types and size of the oider kinds, so that the new beauties are almost unbelievable until one has grown them. They should be well cared for, given a good soil and an occasional taste of Jime, which will improve their foliage and color.

Delphinium belladonna. Pale blue flowers, occasionally touched with mauve, in spreading sprays which bloom almost ail season. This is especially good near pink rambler roses or among Madonna lilies.

\section{DELPHINIUM, continued}

D. bellamosum. Dark blue form of Belladonna.

D. elatum. Bee Larkspur. 5 to $6 \mathrm{ft}$. June to September. Dark blue flowers in long spikes. If plants are cut back when through flowering, they will blossom a second time.

D. formosum. Hardv Larkspur. 3 to $4 \mathrm{ft}$. June and July. A splendid old hardy plant, with rich blue flowers, tinged with purple, and having white eye. One of the finest for permanent effects because it persists so long.

D. formosum colestinum. Sky-blue Larkspur. A light blue form of Formosum.

D. grandiflorum chinense. Slender Larkspur. 2 to $3 \mathrm{ft}$. June to August. One of the finest of the Iowergrowing types, with numerous very large flowers of varying shades of blue, lilac, mauve, and pale blue.

D. grandiflorum album. White Siberian Larkspur. A pure white-flowering form.

D. grandiflorum azureum. A selected pure blue form. Very choice.

\section{Mixed Hybrids \\ Blackmore \& Langdon's Hybrids}

Seedlings from the famous prize-winning strain of one of the greatest Delphinium growers in the world. These make tall, sturdy. plants of perfect habit, with large flowers in all shades of blue, lavender, violet, and mauve. This strain is famous wherever Delphiniums are grown and always arouses great enthusiasm. $50 \mathrm{cts}$. each, $\$ 4$ for $10, \$ 35$ per 100 .

Gold Medal Hybrids. 3 to $5 \mathrm{ft}$. June and July. Stately, decorative plants for masses, beds, and clumps. The flowers range in color from light azure to deep blue and from delicate lavender to purple. A splendid strain of high-class Delphiniums for mass planting and general garden effects.

\section{Named Delphiniums}

The following list represents a carefuI selection from the many improved, named varieties which have been imported and tested. These are hybrids of many types and vary tremendously in height, form of spike, and in delicacy of shades and combinations of tints. They are the supreme product of the best hybridizers, and we recommend them highly. They have been carefully selected from seedlings of the best named varieties from English seed and are strong, heavy plants. We believe they are really superfine varieties bound to make a sensational display, and a source of continual pleasure and satisfaction.

Advancement. 7 to $8 \mathrm{ft}$. Enormous flowers and gigantic spikes nearly a foot in diameter at the base tapering to a symmetrical cone. Clear, reddish blue, with mauve center. \$5 each.

Bay State Seedling. An unusual variety with double, delicate mauve blossoms. 90 cts. each, $\$ 7.50$ for 10 .

Countess Cowley. $5 \mathrm{ft}$. Light blue and mauve, semi-double flowers of wonderfully fine form; black eye. Magnificent spikes. \$3 each.

Edward Bromet. $5 \mathrm{ft}$. The purplish blue ground is especially rich and the white eye extremely large. Individual pips are of enormous size and are well set on immense spikes. $\$ 2.50$ each.

Glory. $4 \mathrm{ft}$. Mauve and ultramarine-blue, shaded rose with white eye. Stout, sturdy plant, producing a very long spike. $\$ 1.50$ each.

Great Strides. 4 to $5 \mathrm{ft}$. Long spires of giant, semidouble flowers of pale blue, blended with pinkish mauve, emphasized by a striking black center. \$3 each.

Happy Thought. $5 \mathrm{ft}$. Enormous flowers with medium blue outer petals, shaded pansy-violet and amethyst with a bright gold and brown bee. Late flowering. \$3 each. 


\section{DELPHINIUMS, continued}

Lamartine. 3 to $4 \mathrm{ft}$. Large, single, dark gentianblue flowers, borne on branching plants similar to Belladonna in habit. 90 cts. each, \$7.50 for 10 .

Moerheimi. 5 to $6 \mathrm{ft}$. June until autumn. A beautiful new hybrid producing pure white flowers without any shading. A free and continuous bloomer. 90 cts. each, $\$ 7.50$ for 10 .

Moerheimi, Improved. 5 to $6 \mathrm{ft}$. June to October. Strong, hardy grower with Iarger, whiter flowers than the preceding. $90 \mathrm{cts}$. each, \$7.50 for 10 .

Mrs. Norman Holden. $5 \mathrm{ft}$. Mauve and blue, semidouble flowers of unusual size, set off by a glittering black eye. Very handsome. \$3 each.

Mrs. Shirley. 5 to $6 \mathrm{ft}$. Lovely lilac-mauve variety, with white and sulphur eye. \$2 each.

Mrs. Townley Parker. $5 \mathrm{ft}$. Single. Sky-blue, white eye. $\$ 1.50$ each.

R. A. Pilkington. $5 \mathrm{ft}$. Very Iarge, semi-double flowers of rich purple-violet, edged blue. $\leqslant 3$ each.

The Bishop. $5 \mathrm{ft}$. Bright royal-blue, Iarge and conspicucus white center. An outstanding variety.
S3 each.

The Shah. $5 \mathrm{ft}$. Large, semi-double, circular flowers consisting of several rows of deep rosy lavender petals with dark eye. Spikes extra Iong and finely proportioned. \$3 each.

\section{DIANTHUS • Pink}

Delightful edging or border plants, aIso including a great many excellent rock plants. The Dianthus family is extensive and has long been one of the most popular garden flowers, embracing the fragrant, old-fashioned Pinks and Carnations, and the charming China Pinks and the beloved Sweet Williams. As a race they like good soil and a situation which will be dry in winter. They should be planted in masses to get the best effects.

*Dianthus alpinus. 3 in. A dainty little Pink from the Tyrolean AIps, with pure pink flowers in great abundance. A splendid rock-garden subject and suitable for edging paths. Likes gritty, well-drained, limestone soil. $\$ 1.20$ for 3, \$3.50 for 10 .

*D. arenarius. Sand-loving Pink. 5 to 8 in. July to September. White, fragrant flowers, with occasional purple tints, produced in masses over the mat-like foliage. An excellent rock plant.

D. allwoodi. Allwood's Pinks. 12 to 15 in. May to October. An ever-flowering race of Pinks, with very fragrant, single or double flowers on long stems suitable for cutting or garden decoration. The colors run through many shades of white, pink, and crimson.

D. allwoodi, Jean. Pure white, with deep violetcrimson center. $\$ 1.05$ for 3, \$3 for 10 .

D. allwoodi, Robert. A delicate shade of old-rose, with light maroon center. \$1.05 for 3, \$3 for 10

D. barbatus. Sweet William. 10 to 20 in. June and July. One of the oldest garden flowers, which perpetuates itself by self-sowing. Flat heads of fringed flowers, many marked with a distinct eye, varying through shades of pink, red, and white. 75 cts. for $3, \$ 2.20$ for $10, \$ 15$ per 100 .

D. barbatus, Newport Pink. An especially choice variety of a lovely salmon-pink color.

D. barbatus, Scarlet Beauty. A deep rich scarlet. For Double Sweet William, see D. latifolius

*D. cæsius. Cbeddar Pink. 3 to 6 in. May to July. Makes close tufts of grayish foliage from which it produces its delicate pink, fragrant flowers. Excellent in sunny place in the rock garden or as an edging.

D. caryophyllus. Hardy Carnations. 12 to 20 in. June and July. Fine double-flowering border plants producing great quantities of Iovely pink, scented flowers which are splendid for cutting or garden decoration.

D. caryophyllus, Grenadin. 12 in. A fine doubleflowering scarlet type of compact growth.

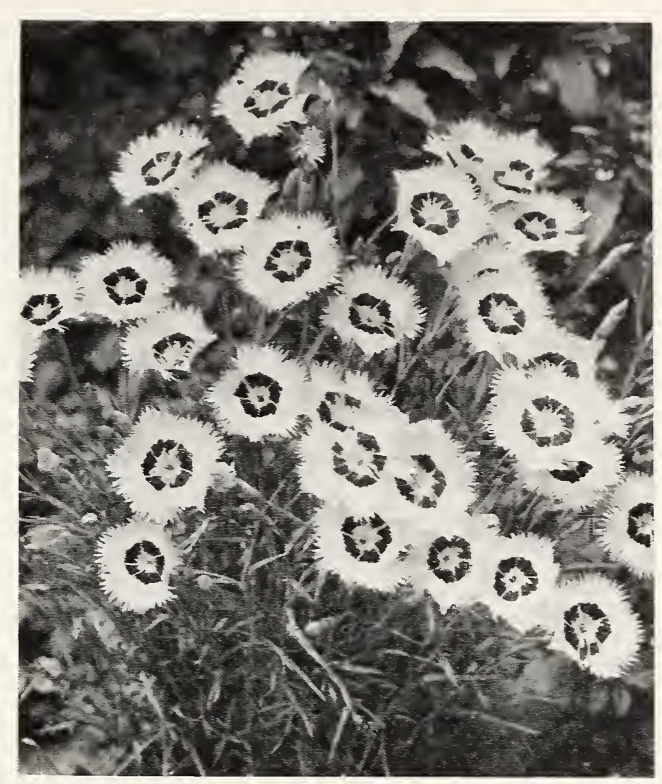

Dianthus plumarius. One of the daintiest Pinks

\section{DIANTHUS, continued}

D. caryophyllus, Grenadin White. A white variety which is a delightful border plant.

D. chinensis Heddewigi. Heddewig Pink. 6 to 9 in. June to autumn. Flowers are very Iarge and vary from pure white to richest crimson, many curiously marbled and streaked and fringed. Very charming.

*D. deltoides. Maiden Pink. 6 in. June and July. One of the prettiest border Pinks of creeping habit, with dark pink, crimson-eyed flowers on slender, erect stems. Good for rock-garden and edging purposes.

*D. deltoides albus. Wbite Maiden Pink. 6 in. June and July. A variety with white flowers.

*D. deltoides, Brilliant. 6 to 9 in. June and July. An improved variety with tiny, rosy crimson flowers.

*D. dentosus. Ragged Pink. 6 in. June and July. Flowers single, fringed and zoned on purple base, much like $D$. chinensis in appearance. Not fragrant. Very pretty and informal among rocks or in border.

*D. latifolius atrococcineus fl.-pl. Double Cluster Pink. 6 to 8 in. June to October. A hybrid, everblooming Sweet William, producing masses of the brilliant, double, fiery crimson flowers. Excellent for border or rock garden.

*D. neglectus. 3 to 6 in. A fine Iarge-flowered Pink from the Alpes-Maritimes, and one of the gems of the family. The fringed flowers vary from deepest carmine-pink to palest rose, and are mostly pale buff-yellow on the backs of the petals. Thrives on well-drained, sunny slopes, and is a perfect rockgarden subject because of its compact, dwarf habit. 90 cts. for $3, \$ 2.50$ for 10 .

*D. plumarius. Grass Pink. 9 to 12 in. June. Pink, purplish, and white, fragrant flowers. An old-fashioned favorite much used for edging and bedding. Especially good for border or rock garden. Blooms continuously if flowers are cut when they begin to fade. 75 cts. for $3, \$ 2.20$ for $10, \$ 15$ per 100 .

D. plumarius semperflorens. Perpetual Pink. Charming pink flowers produced throughout the summer. 75 cts. for $3, \$ 2.20$ for $10, \$ 15$ per 100 .

$* D$. speciosus. Lacy, fragrant flowers of Iavenderpink, especially adapted to hot and dry positions.

D. superbus. Lilac Pink. 10 to 20 in. June to August. A charming variety, with fringed lavenderpink flowers which are very fragrant. 90 cts. for 3 , \$2.40 for 10 . 


\section{Hardy Garden Pinks}

This group contains hybrids of many of the preceding species and selected garden strains. AII are charming subjects, most of which are delightful when cut, for the delicate poise of the flowers and their delicious fragrance. To enjoy them fully they should be planted in masses. They make compact cushions of gray foliage which is very decorative in the border or when used for edging.

Abbotsford. Rich crimson flowers, marked white. *Carmen. 6 in. Light pink; fragrant.

Delicata. 12 in. May and June. Large, single flowers of rose-pink sometimes striped with red 90 cts. for $3, \$ 2.50$ for $10, \$ 20$ per 100 .

*Essex Witch. Bright but delicate pink, finely fringed flowers.

*Fürst Bismarck. 6 to 8 in. Never out of bloom during summer. Same shade as Paul Neyron rose slightly darker. Dark green foliage. Lovely hardy Pink. $\$ 1.05$ for $3, \$ 3$ for $10, \$ 20$ per 100 .

*Her Majesty. Very large, smooth-edged flowers of pure, glistening white.

*Homer. Rosy red, with a dark center. $\$ 1.05$ for 3 $\$ 2.70$ for $10, \$ 20$ per 100 .

*Lord Lyons. A beautiful, fully double variety of soft Iavender-pink.

*Louisa M. Alcott. Large, deep pink.

*Mrs. Sinkins. Large, white, fragrant fringed flowers delightful for cutting.

*Rose de May. 9 to 15 in. Everyone who has seen this Pink has liked it. The delicate pink blossoms, which are borne steadily throughout the summer will delight you with their exquisite fragrance. Add several of them to your garden. $\$ 1.05$ for $3, \$ 2.70$ for $10, \$ 20$ per 100 .

*White Reserve. Exceptionally fragrant, pure white flowers produced continuously.

\section{DICENTRA}

*Dicentra eximia. Fringed Bleeding-beart. $1 \mathrm{ft}$. AIl summer. A delicate-looking, plume-like plant with fern-like foliage and drooping racemes of curious rose-colored blooms. Excellent in shady places, rock garden, and mixed border. $\$ 1.05$ for $3, \$ 2.70$ for $10, \$ 20$ per 100 .

*D. formosa. Western Bleeding-heart. 15 in. April to August. Similar to the preceding, with finely cut foliage and showy pink flowers. $\$ 1.05$ for $3, \$ 2.70$ for $10, \$ 20$ per 100 .

D. spectabilis. Bleeding-beart. $2 \mathrm{ft}$. Late Apri to July. Large, rosy red, heart-shaped flowers. A fine old-fashioned flower desirable for planting in the shade. 75 cts. each, $\$ 7$ for 10,60 per 100 .

\section{DICTAMNUS • Gas Plant}

Dictamnus albus. Gas Plant. 2 to $3 \mathrm{ft}$. June and July An old garden favorite, with white flowers which will sometimes give a flash of light on a summer evening when a lighted match is held near the base of the flower-spike, leaving a strong scent of lemons. A fine permanent border plant which endures for many years. $\$ 1.20$ for $3, \$ 3.50$ for 10 .

D. albus caucasicus. Giant Gas Plant. 3 to $4 \mathrm{ft}$ June and July. Similar to D. albus but Iarger in al respects, producing flower-spikes fully twice as Iong. $\$ 1.35$ for $3, \$ 4$ for $10, \$ 35$ per 100 .

D. albus ruber. Purple Gas Plant. 2 to $3 \mathrm{ft}$. June and July. Similar to the above, but has very fragrant flowers of reddish color. $\$ 1.20$ for $3, \$ 3.50$ for $10, \$ 25$ per 100 .

\section{DIGITALIS • Foxglove}

There is an uncommon dignity and stateliness to the Foxgloves which make them invaluable for permanent and settled effects in the garden. They seem to add an air of calmness and peace to any

\section{DIGITALIS, continued}

situation, and are best at the back of the border, or grouped in a little bay in the shrubbery. Should be planted in bold masses to get best effect.

Digitalis ambigua. Yellow Foxglove. 2 to $3 \mathrm{ft}$. June and July. A hardy plant, with slender spikes of medium-size yellowish flowers, marked with brown. Effective in groups in wild garden and when near pale mauve or magenta flowers.

D. lanata. Grecian Foxglove. 2 to $3 \mathrm{ft}$. July and August. A slender persistent perennial, with spikes of rather small grayish or purplish yellow flowers. A very different and interesting form.

D. purpurea. Common Foxglove. 2 to $3 \mathrm{ft}$. July to September. Handsome tubular flowers in tall terminal racemes. The blooms are purple on the outside, marked inside with dark purple spots, edged with white. The old-fashioned garden favorite adapted to wild garden or border, or for planting among shrubbery.

D. purpurea alba. Common White Foxglove. A beautiful white form of the Common Foxglove. D. purpurea gloxiniæeflora. Gloxinia Foxglove. 3 to $4 \mathrm{ft}$. June and July. A highly improved popular variety, with Iarge flowers ranging from pure white to deep purple. Robust habit.

D. purpurea gloxiniæflora rosea. 2 to $3 \mathrm{ft}$. June and July. A selected form with charming rosecolored flowers.

D., Shirley Hybrids. A magnificent strain raised by the originator of the famous Shirley poppies. The plants grow 5 to 7 feet taII, with flower-spikes 4 feet long, carrying blooms of enormous size, ranging from white to dark rose-purple, handsomely spotted with crimson, maroon, and dark mahogany-brown. \$1.05 for $3, \$ 3$ for $10, \$ 24$ per 100 .

\section{DODECATHEON}

*Dodecatheon meadia. Common Shootingstar. 1 to $2 \mathrm{ft}$. May and June. A tufted plant from which arise tall slender stems bearing a cluster of rosecolored flowers Iike small cyclamens, with the petals bent backward and the stamens forming a sharp point. A most interesting and beautiful plant for grouping in shady places. 90 cts. for $3, \$ 2.40$ for 10 .

\section{DORONICUM - Leopardbane}

Doronicum caucasicum. Caucasian Leopardbane. $1 \mathrm{ft}$. May and June. Yellow daisy-like flowers generally borne one to a stem. Succeeds well in ordinary soil and is very good for cutting. $50 \mathrm{cts}$. each, $\$ 4$ for 10 .

D. clusi. Downy Leopardbane. $2 \mathrm{ft}$. Larger flowers than $D$. caucasicum and blooms a little later. The foliage and stems are covered with silky hairs. $50 \mathrm{cts}$. each, $\$ 4$ for $10, \$ 36$ per 100 .

D. magnificum. Sunflower Leopardbane. A very attractive sort with Iarge flowers resembling a single sunflower. 50 cts. each, $\$ 4$ for $10, \$ 36$ per 100 .

D. plantagineum excelsum. Showy Leopardbane. 2 to $3 \mathrm{ft}$. May and June. Vigorous, bushy plants with showy orange-yellow flowers about 4 inches across. 50 cts. each, $\$ 4$ for $10, \$ 36$ per 100 .

\section{DRABA}

Draba fladnizensis. Arctic Whitlowgrass. 4 in. A fine little rock plant of creeping habit, with yellowish white flowers in early spring. $\$ 1.50$ for $3, \$ 4$ for 10 . *D. repens. 2 to 3 in. Dense little rosettes of leaves covered with yellow flowers in early spring. Handsome in the mass and a splendid rock plant. $\$ 1.50$ for $3, \$ 4$ for $10, \$ 30$ per 100 .

\section{ECHINACEA}

Echinacea purpurea. Purple Coneflower. 2 to $31 / 2 \mathrm{ft}$. July and August. Large, reddish purple, daisyIike flowers, with drooping rays which increase in length as the flower opens. Showy, vigorous plants. 


\section{ECHINOPS • Globe Thistle}

Echinops pumilum. Globe Thistle. $3 \mathrm{ft}$. August. Dark bue heads, somewhat smaller than $E$. ritro. 75 cts. for $3, \$ 2.20$ for $10, \$ 15$ per 100 .

E. ritro. Steel Globe Tbistle. $4 \mathrm{ft}$. July and August. Handsome thistle-like foliage and large, globular heads of blue flowers. A wild-garden plant and looks weIl combined with yellow Helianthus or even Bocconia cordata.

E. sphærocephalus. Common Globe Tbistle. 5 to 7 ft. A much more vigorous background plant, with bluish flowers and yellowish spines. 75 cts. for 3 , $\$ 2.20$ for $10, \$ 15$ per 100 .

\section{EPIGÆA - Trailing Arbutus}

*Epigæa repens. Trailing Arbutus. 4 in. Apri May. Matted evergreen sub-shrub or trailer with clusters of intensely fragrant, delicately pink flowers of exquisite beauty. Give it shade, good drainage, and a sour, peaty soil. $\$ 1.05$ for $3, \$ 2.70$ for 10 $\$ 20$ per 100 .

\section{EPILOBIUM}

Epilobium angustifolium. Blooming Sallv. 3 to $4 \mathrm{ft}$. June to August. A very handsome plant which spreads rapidly. Valuable for shrubberies or along streams, producing showy spikes of clear red flowers.

\section{EPIMEDIUM}

Choice plants for the rock garden or shady places in the border. They belong to the very interesting Barberry family, aII of which are curious and beautiful. They do weIl in most soils. The foliage of all is attractive.

*Epimedium alpinum. Alpine Epimedium. 9 in. May and June. A charming little plant with bronzy foliage and sprays of curious, spurred flowers of grayish red and yellow. $50 \mathrm{cts}$. each, $\$ 4.50$ for 10 .

*E. macranthum niveum. Snowy Epimedium. 9 in. April and July. A very pretty plant with leaves in groups of three and clusters of pure white flowers with prominent spurs. One of the finest. 50 cts. each, $\$ 4.50$ for 10 .

*E. pinnatum elegans. 9 in. June to August. A woollier plant than the previous kinds, with many bright red flowers. Very pretty. $50 \mathrm{cts}$. each.

*E. pinnatum sulphureum. 8 to 10 in. April to July. A form similar to the preceding but with large, pale yellow flowers of almost orchid-like quality. A very precious little plant. $50 \mathrm{cts}$. each, $\$ 4.50$ for 10

\section{ERIGERON - Fleabane}

Perennials of very easy culture, producing aster. like flowers on slender stems rising from a compact rosette of foliage. They bloom early and are very showy planted in masses in the border or rockery, showing up much better in big clumps than as scattered plants.

*Erigeron caucasicus. 12 in. Early. Large flowers with bright violet rays and rich yellow centers. $\$ 1.50$ for $3, \$ 4$ for 10 .

*E. coulteri. 15 in. July. A native of the Rocky Mountains, producing charming pearly white flowers, two or three together on slender stems.

*E. glabellus. Smooth Fleabane. 6 to 8 in. Large flowers with small golden eye. Rays very slender and violet-purple. Attractive and variable in height, blooming in clusters on slender leafless stems.

*E. speciosus. Oregon Fleabane, $2 \mathrm{ft}$. June and JuIy. Large, handsome blue flowers, tinted violet, with yellow centers. Very desirable for cutting. Plant in masses in rock garden or border.

*E., Quakeress. 18 in. June and July. A choice hybrid variety with mauve-pink flowers frequently borne all season.

\section{ERINUS}

Erinus alpinus. Alpine Liver Balsam. 3 to 4 in. April to June. A tiny plant suitable for massing on banks or among stones which it covers with a mantle of rosy purple flowers. $\$ 1.05$ for $3, \$ 3$ for 10 .

$*$ E. alpinus albus. A form of the foregoing, with white flowers. $\$ 1.05$ for $3, \$ 3$ for 10 .

\section{ER YNGIUM • Eryngo}

Eryngium alpinum. Bluetop Eryngo. $2 \mathrm{ft}$. A bold, picturesque plant with numerous heads of flowers of attractive blue, which color extends to the leaves of the upper part of the plant.

E. amethystinum. Ametbyst Eryngo. $2 \mathrm{ft}$. June to September. The handsome flowers, foliage, and stems are deep amethyst-blue. A useful plant for winter decoration, when colored and dried.

E. aquaticum. Button Snakeroot. 2 to $6 \mathrm{ft}$. A strong erect plant suited to wet soil. The bluish heads are large and attractive.

\section{ER YSIMUM}

*Erysimum pulchellum. Rockery Blister Cress. 6 to 12 in. A dwarf rock plant bearing tufts of light sulphur-yellow flowers. Closely related to the waIlflowers.

\section{EUPATORIUM}

Eupatorium aromaticum melissoides (frazeri) Melissa Thoroughwort. 2 to $3 \mathrm{ft}$. August to October. Delicate white flowers in Iarge terminal heads. Useful for cutting and grows well in poor, sandy soil.

E. cœlestinum. Mist flower. $2 \mathrm{ft}$. August to October. A wiry plant producing heads of misty flowers of delicate heliotrope-purple. Splendid for mass planting, blending well with early yellow chrysanthemums. $\$ 1.05$ for 3, $\$ 2.70$ for $10, \$ 20$ per 100 .

E. purpureum. Joe-Pye-Weed. 6 to $7 \mathrm{ft}$. Autumn. A gigantic perennial with whorled leaves and branching heads of purple flowers 18 inches across. Naturalizes well on banks of streams or wet meadow-land. 75 cts. for $3, \$ 2.20$ for $10, \$ 15$ per 100 .

E. urticæfolium (ageratoides). Snow Thoroughwort. 2 to $3 \mathrm{ft}$. August and September. A superb native plant with handsome heads of feathery pure white flowers. $\$ 1.05$ for $3, \$ 2.70$ for $10, \$ 20$ per 100 .

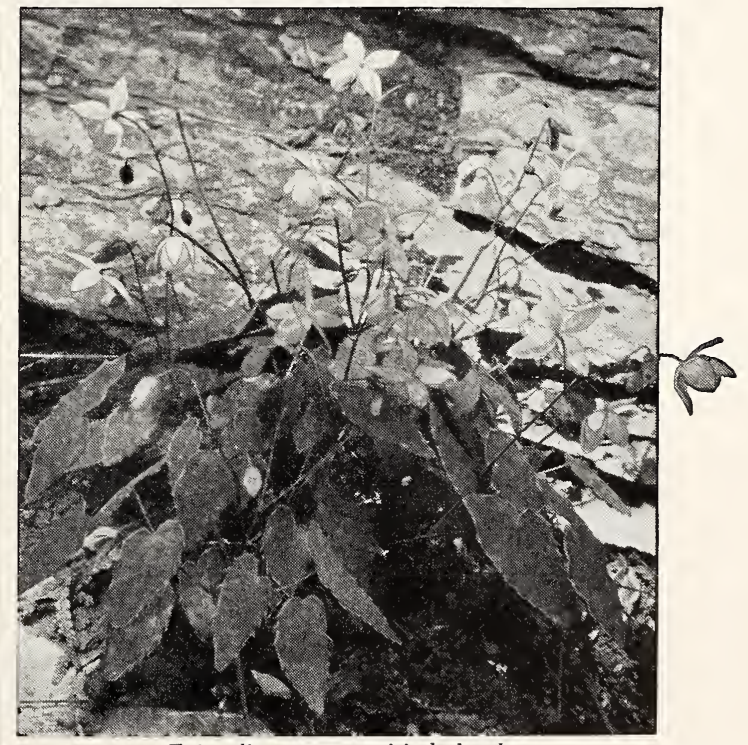

Epimediums are exquisitely lovely 


\section{EUPHORBIA}

Euphorbia corollata. Flowering Spurge. 18 in. July and August. An erect plant bearing broad clusters of pure white flowers with green eye which can be used like gypsophila for mixing with other flowers. 75 cts. for $3, \$ 2.20$ for $10, \$ 15$ per 100 .

E. myrsinites. 4 to 6 in. May and June. A very pretty creeper with thick bluish leaves and yelloworange flowers. $\$ 1.05$ for $3, \$ 2.70$ for $10, \$ 20$ per 100 .

\section{HARDY FERNS}

The Ferns of New England take as readily to cultivation as the common garden flowers. While flowers require a sunny place, Ferns delight in some shady nook; they also can be grown in boxes or pans on the porch, in the house or under trees, any place that is shady, but are not suitable for house culture in winter, for that is their time of rest.

The price of all hardy Ferns is 90 cts. for 3 of a kind, $\$ 2.40$ for $10, \$ 18$ per 100

*Adiantum pedatum. American Maidenbair Fern. 12 to 15 in. One of the finest native Ferns. Grows with exceedingly graceful fan-like foliage which produces a handsome effect when massed in broad patches. Plant 8 inches apart.

*Asplenium platyneuron (ebeneum). Ebonv Spleenwort. 6 to 15 in. A splendid Fern for stony places and in dry woodlands and very desirable for rock-garden work.

*Athyrium filix-femina. Lady Fern. 2 to $3 \mathrm{ft}$. Finely cut foliage of rich green, making a handsome specimen plant if well grown in moist soil, either in sun or shade. Massed $2 \frac{1}{2}$ to 3 feet apart it makes a splendid rich display.

*Cryptogramma acrostichoides. American Rockbrake. 6 in. A small, evergreen Fern of delightful form which is eminently adapted to the rock garden and for edging shady borders.

*Dennstedtia punctilobula. Hay-scented Fern. $11 / 2$ to $2 \mathrm{ft}$. A good massing Fern, with broad fronds. Increases rapidly and good for naturalizing.

Dryopteris goldiana. Goldie's Fern. 2 to $4 \mathrm{ft}$. Very stately Fern with handsome fronds 12 to 18 inches wide. Its unusual beauty and grace make it desirable in all fern-plantings.

*D. marginalis. Leatber Woodfern. $2 \mathrm{ft}$. An evergreen species with leathery, rather stiff foliage, adapted especially to rocky places. Good when cut for mixing with flowers.

D. spinulosa. Toothed Woodfern. $11 / 2$ to $2 \mathrm{ft}$. Very strong evergreen Fern which makes a splendid ground-cover under shrubs and deserves a place in any collection of Ferns.

Onoclea sensibilis. Sensitive Fern. $1 \mathrm{ft}$. A rather rough Fern with large, triangular fronds. It likes a moist situation and will grow in places too wet for other Ferns.

Osmunda cinnamomea. Cinnamon Fern. 2 to $5 \mathrm{ft}$. Very handsome Fern of perfect habit with big fronds in circular clusters. Woolly when young and its big "fiddleheads" are interesting and amusing in the spring. Likes rich, moist soil, where it develops noble proportions.

O. regalis. Royal Fern. 2 to $5 \mathrm{ft}$. This very handsome form grows to perfection in thin shade with plenty of moisture. Its spore-bearing fronds rise high above the plant and are most unusual.

Polypodium vulgare. Common Polypody. 4 to 10 in. A good evergreen Fern for rockwork and borders, forming mats of durable foliage. Plant in well-drained soil, about 4 to 5 inches apart.

*Polystichum acrostichoides. Christmas Fern. $1 \mathrm{ft}$. Very hardy evergreen Fern which is useful in almost all positions, especially in the rockery. Very pretty and needs only common, well-drained soil.

Pteretis nodulosa. Ostrich Fern. 2 to $4 \mathrm{ft}$. One of the handsomest, with big feathery fronds 6 to 10 inches wide. Good at the background of other Ferns or suitable as a specimen. It needs good soil, and will thrive in the sunlight.

\section{FESTUCA - Fescue}

*Festuca glauca. Blue Fescue. 10 to 12 in. An ornamental grass which makes dense tufts of very narrow bluish leaves, excellent in contrast with darker foliage. Desirable for rock-garden or edging purposes.

\section{FILIPENDULA · Meadowsweet}

These are handsome, spirea-like flowers blooming in early midsummer. They delight in cool, rich soil, and look especially well at the back of the border, where their fern-like foliage and feathery and foamy flowers form an admirable background for the plants in front of them. Plant them in bold, broad masses or considerable drifts to give a permanent, stable effect.

Filipendula camtschatica (Spiræa gigantea) Kamcbatka Meadowsweet. 5 to $6 \mathrm{ft}$. July. A bold background plant with frothy, white flowers held well above the foliage.

*F. hexapetala (Spiræa filipendula). Dropwort. 2 to $3 \mathrm{ft}$. June and July. This fine perennial bears clusters of rather large, cream-white flowers. It prefers a rather dry situation in full sunlight.

*F. hexapetala flore-pleno. Double Dropwort. 18 to 24 in. A handsome double-flowering form of the preceding. 90 cts. for $3, \$ 2.40$ for 10 .

F. purpurea (Spiræa palmata). Japanese Meadowsweet. 2 to $4 \mathrm{ft}$. June to August. Undoubtedly the finest of the Meadowsweets, with carmine or dark pink flowers in large clusters on strong wiry dark crimson stems. Very desirable. $\$ 1.05$ for $3, \$ 2.70$ for $10, \$ 20$ per 100 .

F. purpurea alba. White Japanese Meadowsweet 2 to $4 \mathrm{ft}$. June to August. A dainty white variation of the preceding. $\$ 1.05$ for $3, \$ 2.70$ for $10, \$ 20$ per 100.

F. purpurea elegans. Showy Japanese Meadowsweet. 2 to $4 \mathrm{ft}$. June, July. One of the most useful hardy plants, with dark green foliage, and purple-red stems and branches, passing into the silvery pink of the broad corymbs of flowers which are very freely produced.

F. rubra venusta. Carmine Meadowsweet. 4 to $5 \mathrm{ft}$. June and July. A vigorous plant for the back of the border with very Iarge heads of rich, carmine-pink flowers. $\$ 1.05$ for $3, \$ 3$ for $10, \$ 24$ per 100 .

F. ulmaria. Queen of the Meadows. 4 to $5 \mathrm{ft}$. June and August. Pure white foam-like, fragrant flowers in dense heads. A fine, old-fashioned garden plant, very widely cultivated.

F. ulmaria flore-pleno. Double European Meadowsweet. 3 to $4 \mathrm{ft}$. June to August. Dense panicles of double white flowers. 75 cts. for $3, \$ 2.20$ for 10 , $\$ 15$ per 100 .

\section{GAILLARDIA}

Gaillardia aristata. Common Perennial Gaillardia. $11 / 2$ to $2 \mathrm{ft}$. June to November. The blooms are 2 to 3 inches across with dark red and brown centers, and orange, crimson, and red rays shaped into rings of color. 90 cts. for $3, \$ 2.50$ for $10, \$ 20$ per 100 .

G. aristata, Golden Gleam. Pure yellow flowers without marks or other colors, of great size, and carried erect on stout, wiry stems. Good as a cutflower and a garden plant of fine habit and effective color. $\$ 1.05$ for $3, \$ 3$ for 10 .

G. aristata grandiflora. $2 \mathrm{ft}$. July to autumn. Large, gorgeous flowers of crimson and gold are borne throughout the season. 75 cts. for $3, \$ 2.20$ for 10 , $\$ 15$ per 100.

G. aristata, Portola. A much improved variety with flowers of exceptional size and substance, brilliantly colored. This is a decided improvement in color, habit, and refinement over the varieties commonly grown. 90 cts. for $3, \$ 250$ for $10, \$ 20$ per 100 . 


\section{GALAX}

Galax aphylla. 8 to 10 in. June. Large, round, varnished, evergreen leaves, which turn deep bronze in autumn. The slender spike of white flowers is pretty and graceful. Demands acid soil, moisture, and heavy shade. Foliage fine for Christmas greens. 90 cts. for $3, \$ 2.40$ for ${ }^{10} 0, \$ 18$ per 100 .

\section{GALEGA - Goatsrue}

Galega heldreichi. 2 to $3 \mathrm{ft}$. June to frost. Very bushy plants with large lavender flowers like pea blossoms, borne in fine clusters. A good and seldom seen perennial. $\$ 1.05$ for $3, \$ 2.70$ for $10, \$ 20$ per 100 .

G. officinalis. Common Goatsrue. 2 to $3 \mathrm{ft}$. June to September. A slender, bushy plant with lilac-purple flowers in compact racemes. $\$ 1.05$ for $3, \$ 2.70$ for 10 , \$20 per 100 .

G. officinalis alba. Albino Goatsrue. Form and habit same as the above, but flowers are white. $\$ 1.05$ for 3 , \$2.70 for 10 , \$20 per 100 .

G. officinalis hartlandi. Hartland Goatsrue. An excellent form of the Common Goatsrue with variegated flowers of white and Iavender. $\$ 1.05$ for $3, \$ 2.70$ for 10 , $\$ 20$ per 100 .

\section{GALIUM}

Galium boreale. Nortbern Bedstraw. 2 to $3 \mathrm{ft}$. June to September. The delicate sprays of minute white flowers and fine slender leaves in whorls make this an excellent variety for cutting, giving a light, airy effect to masses of heavier flowers.

\section{GAULTHERIA · Wintergreen}

*Gaultheria procumbens. Wintergreen. A Iow, smallleaved evergreen, which bears clusters of bright red aromatic berries, sought for their fragrance and flavor. It grows in association with Epigæa repens and enjoys the same sharp acid soil and good drainage. Makes a fine evergreen carpet where it is happy.

\section{GERANIUM • Cranesbill}

A group of delightfuI spring-flowering plants which are very effective among stones and in semishaded places. The common Wild Geranium is one of the handsomest wild flowers, and it takes kindly to cultivation. It blooms with the pale vellow Rosa bugonis and makes a delightful combination of color when planted beneath and in front of that shrub.

*Geranium grandiflorum. Lilac Cranesbill. $1 \mathrm{ft}$. June to August. Large, open, violet-blue flowers with a satiny Iuster. Especially suited to rock gardens.

G. maculatum. 12 to 18 in. April to August. The Wild Geranium of our woods and frelds. Its rather Iarge, light purple flowers are borne in loose clusters above the mound of foliage. A delightful plant which takes kindly to gardens and may be successfully combined with many other flowers.

*G. sanguineum. Bloodred Cranesbill. 18 in. May to October. The plants are of compact habit, with bright blood-red flowers. Good for wild garden, rock garden, or border.

\section{GEUM - Avens}

Geum chiloense. 1 to $1 \frac{1}{2} \mathrm{ft}$. May to July. Bright red, single flowers in terminal clusters, very bright and showy. A good low border plant. \$1.50 for 3 , \$4 for 10 .

G. chiloense atrosanguineum atrococcineum fl.-pl. Dwarf plant with dark red, rose-like flowers. Similar to $G$. atrosanguineum, but flowers are larger and more double.

$*$ G. chiloense, Lady Stratheden. $2 \mathrm{ft}$. June. Deeply crimped, semi-double, pure golden yellow flowers. Like the more common Mrs. Bradshaw except in color. $\$ 1.05$ for $3, \$ 3$ for 10 .

\section{GEUM, continued}

G. chiloense, Mrs. Bradshaw. 12 to 15 in. June to September. A very choice variety with large, double, brilliant scarlet flowers. $\$ 1.05$ for $3, \$ 3$ for $10, \$ 20$ per 100 .

\section{GILLENIA}

Gillenia trifoliata. Bowmansroot. $3 \mathrm{ft}$. June and July. A graceful spirea-like plant, with slender, dark red stems, clothed with pretty, star-shaped, rosepink and white flowers. Effective planted liberally with Iilies and irises. $\$ 1.05$ for $3, \$ 2.70$ for $10, \$ 20$ per 100 .

\section{GLADIOLUS BULBS}

Most gardeners find that Gladiolus interplanted with the early-flowering perennials, shoot up a mong them, and take possession of their space when they are through blooming, thus giving a second period of very desirable bloom. Of course, they are splendid when bedded by themselves, and that is really the best way to grow them for either garden display or for fine, individual cut spikes.

Our list of Gladiolus is not Iong, but it includes splendid varieties in a fine assortment of colors. We offer good, frrst-class bulbs of flowering size.

Alice Tiplady. Orange-yellow and saffron. Good grower, and very showy. 75 cts. for $10, \$ 6$ per 100 .

Baron Hulot. Deep violet-blue. One of the best of its color. 75 cts. for 10, \$7 per 100.

Carmen Sylva. Snow-white, penciled with lavender in the throat. 75 cts. for $10, \$ 7$ per 100.

Flora. Almost pure golden yellow. Flowers Iarge, and a strong grower. 75 cts. for $10, \$ 7$ per 100 .

Mrs. Dr. Norton. La-France-pink, shading to rose and tinted with sulphur-yellow. 75 cts. for $10, \$ 7$ per 100.

Mrs. Francis King. Light salmon-scarlet; very large and fine. 75 cts. for $10, \$ 6.50$ per 100

Mrs. Frank Pendleton. Salmon-pink, blotched with velvety maroon. 75 cts. for $10, \$ 6.50$ per 100

Peace. Large, white flowers veined lilac on the lower petals. Late blooming. 75 cts. for $10, \$ 7$ per 100.

Pink Wonder. Many massive light pink flowers open at once on heavy spikes. 75 cts. for $10, \$ 7$ per 100 .

Purple Glory. Deepest velvety maroon flowers with darker blotches; petals ruffled at the edges. $\$ 1$ for 10 , $\$ 8$ per 100.

Rose Ash. Flowers duIl ash-rose color, very different from all other shades. 75 cts. for $10, \$ 7$ per 100 .

Scarlano. Light, bright orange-red, with edges finely ruffled. 75 cts. for $10, \$ 7$ per 100 .

War. Large flowers of dark glowing red. Very tall spikes. 75 cts. for $10, \$ 6.50$ per 100 .

Exhibition Mixture. Fine varieties. $\$ 5$ per 100

\section{GYPSOPHILA}

Essential plants in every garden, not so much for their own flowers as for the assistance they render by contrast of color and form to showier plants. This use extends to the cut-flowers which are an important part of every artistic flower arrangement. No satisfactory substitute exists for the feathery, airy grace of Baby's Breath in bouquets of showier, heavier flowers.

Gypsophila acutifolia. Green Gypsopbila. 2 to $3 \mathrm{ft}$. July and August. A plant of feathery habit similar to the popular $G$. paniculata but much brighter and greener bearing. Rose-colored flowers in large panicles. A fine border plant. 90 cts. for 3, \$2.40 for 10 .

*G. cerastioides. Mouse-Ear Grpsopbila. 3 to 4 in. A woolly little plant which forms a dense mat-like growth over rockwork or along edgings, and covers itself with Iarge lilac or white flowers veined pink. 


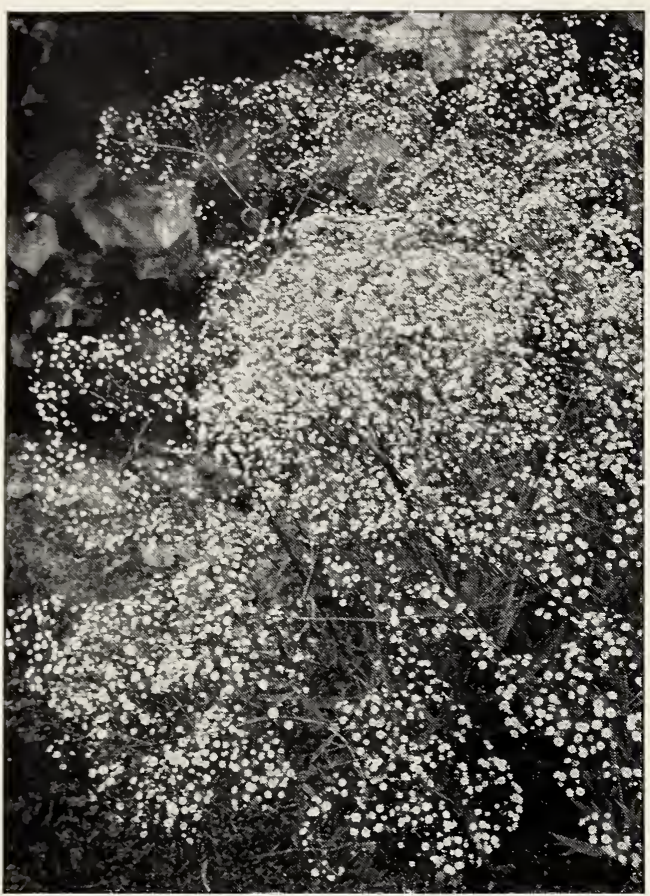

Gypsophila paniculata fl..pl., Bristol Fairy

\section{GYPSOPHILA, continued}

G. paniculata. Baby's Breatb. 2 to $3 \mathrm{ft}$. July and August. A very popular, graceful plant good in the border and large rock garden, where it has a charming, misty, soft gray quality. Flowers small, white, in large, loose panicles, excellent for cutting and mixing with other flowers.

G. paniculata flore-pleno. Double Baby's Breath. $3 \mathrm{ft}$. July and August. A beautiful, double, whiteflowering form of the above. $\$ 1.20$ for $3, \$ 3.50$ for 10 , \$30 per 100 .

G. paniculata fl.-pl., Bristol Fairy. 2 to $3 \mathrm{ft}$. June to October. This is a highly improved form of the preceding variety, with flowers two to three times as big, beginning to bloom two weeks earlier and continuing throughout the whole season, blooming on the tips of new side shoots. The flowers are Iarger, double, with a clearness of color Iacking in the older type; and graceful, delicate, and misty as the common variety is, Bristol Fairy is far superior in appearance, usefulness, and general desirability. The stock is still moderately scarce. 75 cts. each, \$6 for $10, \$ 50$ per 100 .

*G. repens. Creeping Gypsopbila. 6in. June and July. This trailing, spreading plant is fine for steps and rock garden, with myriads of tiny, white flowers in graceful panicles.

\section{HELENIUM • Sneezeweed}

An important group of late summer and autumn flowers, bearing some resemblance to the rather common daisy-like type of flower, but distinguished by curiously reflexed rays and a profusion of massed bloom which is quite distinct. The colors are warm and lively, and combine well with other autumn flowers to give color and comfort to the late season. For best effect, of course, they should be planted in broad masses against the shrubbery, and in particular they look well with some of the misty lavender hardy asters.

\section{HELENIUM, continued}

Helenium autumnale. Common Sneezeweed. 4 to $6 \mathrm{ft}$. August and September. An elegant autumn plant with showy golden yellow flowers borne at the top of branching stems. Suitable for planting among shrubbery.

H. autumnale pumilum. Dwarf Sneezeweed. 1 to $2 \mathrm{ft}$. August and September. A very free-flowering dwarf sort much liked for cut-flowers and the front of the border. $\$ 1.50$ for 3, $\$ 4$ for 10 .

H. autumnale pumilum magnificum. $11 / 2 \mathrm{ft}$. June to September. A very fine and vigorous plant which produces throughout the summer a continuous supply of splendid, soft, pale yellow flowers. $\$ 1.50$ for $3, \$ 4$ for $10, \$ 30$ per 100 .

H. autumnale, Riverton Beauty. 4 to $5 \mathrm{ft}$. August to October. A distinct novelty. Its flowers are of a rich lemon-yellow with a large cone of purplish black. $\$ 1.05$ for $3, \$ 2.70$ for $10, \$ 20$ per 100 .

H. autumnale, Riverton Gem. 4 to $5 \mathrm{ft}$. August to November. The flowers on opening are old-gold, suffused with bright terra-cotta, changing as they mature to mahogany-red. $\$ 1.05$ for $3, \$ 2.70$ for 10 , $\$ 20$ per 100.

H. autumnale rubrum. $4 \mathrm{ft}$. September and October. In color the flowers resemble the blood-red English wallflowers. Fine for cutting. $\$ 1.20$ for 3 , $\$ 3$ for $10, \$ 24$ per 100 .

H. hoopesi. Orange Sneezeweed. 11/2 to $2 \mathrm{ft}$. May to August. A fine border plant with very showy, bright orange-yellow flowers. Especially useful for cutting. $\$ 1.05$ for $3, \$ 2.70$ for $10, \$ 20$ per 100 .

\section{HELIANTHEMUM • Sun Rose}

The surprising beauty of the Sun Roses astonishes everyone who is not familiar with them. The wiry little plants form dense, springy tufts which are covered by the dainty, rose-like flowers in a great variety of delicate shades of pink, copper, and yellow. The various kinds are much alike in habit but are most variable in the color of the flowers, many of which come double at times. It is an indispensable rock plant and should be used liberally wherever there is opportunity.

*Helianthemum chamæcistus (vulgare). Common Sun Rose. 8 to 10 in. June and July. A pretty, almost shrubby evergreen plant having narrow rather wiry foliage with a silvery sheen, which makes a low, thick carpet. Flowers yellow, like small single roses. Desirable for rock garden.

*H. chamæcistus, Bride. 8 to 10 in. Very dainty; delicately white.

*H. chamecistus, Fireball. 4 to 5 in. A dazzling double red variety of an amazingly bright shade.

*H. chamæcistus tomentosum (angustifolium). Rosemary Sun Rose. A similar plant with slightly woolly foliage and pretty yellow, rose-like flowers.

*H. chamrecistus citrinum. 6 in. A beautiful, pale yellow, single-flowered sort, similar to the preceding in other respects.

*H. chamæcistus cupreum (hyssopifolium cupreum). 6 in. A variety with flat, narrow leaves, glossy on the upper surface, and large, coppercolored flowers. It is especially fine in a dry, sunny position in the rock garden.

*H. chamæcistus macranthum. 6 to 12 in. June and July. Pure white flowers of exquisite texture, blotched with yellow at the base of the petals. $\$ 1.05$ for $3, \$ 3$ for 10 .

*H. halimifolium multiflorum. Morocco Sun Rose. 4 to 6 in. June to September. A charming rock plant of spreading growth. Flowers bright orangepink and most attractive.

*H. perfoliatum roseum. 6 to 8 in. June to August. A new trailing. plant producing a profusion of single salmon-pink flowers with yellow centers. Valuable for rock garden.

*H. præcox. 8 in. June and July. A beautiful, silveryleaved variety with Iarge, single, pale yellow flowers. $\$ 1.05$ for $3, \$ 3$ for 10 . 


\section{HELIANTHUS • Sunflower}

For the most part, this group is composed of big showy plants suitable for bordering woodland paths or massing in a naturalistic fashion along streams or before shrubbery. They are very effective planted close to the eupatoriums, either cœlestinum or purpureum, and look well mingled with the great violet ironweed and various of the darker purple hardy asters. Their beauty is in the mass of color they make, and they should be used generously for bold effects.

Helianthus decapetalus. Tbinleaf Sunflower. 4 to $5 \mathrm{ft}$. August to October. A frne free-blooming form, with clear yellow flowers in immense panicles. One of the best late-blooming plants. Desirable for shrubbery border and naturalistic effects. 75 cts. for 3 $\$ 2.20$ for $10, \$ 15$ per 100 .

H. decapetalus multiflorus flore-pleno. Double Golden Tbinleaf Sunflower. Similar to above, but the flowers are double. \$1.05 for 3, \$2.70 for 10 .

H. maximiliani. Maximilian Sunflower. 5 to $7 \mathrm{ft}$ The latest of all to bloom, perfecting its fine golden yellow flowers in long, graceful sprays during October, when all others have finished flowering. 75 cts. for $3, \$ 2.20$ for $10, \$ 15$ per 100 .

H. mollis. Asby Sunflower. 3 to $4 \mathrm{ft}$. July to September. Large, single, Iemon-yellow flowers and downy white foliage. 75 cts. for $3, \$ 2.20$ for 10 , $\$ 15$ per 100.

H. orgyalis. 6 to $8 \mathrm{ft}$. September. Tall and gracefuI, with very leafy stems and flowers 3 to 4 inches in diameter, produced abundantly. Plant among shrubs. 90 cts. for $3, \$ 2.40$ for 10 .

H. rigidus. Prairie Sunflower. 2 to $3 \mathrm{ft}$. July and August. A showy plant making a great display of large, semi-double golden yellow flowers over a very long season.

H. scaberrimus, Miss Mellish. 5 to $6 \mathrm{ft}$. Late August and September. Vigorous, leafy plant with large, graceful, yellow flowers. A very desirable variety either isolated or massed in waste places.

H. scaberrimus, Wolley Dod. $6 \mathrm{ft}$. September. One of the best autumn-flowering varieties, producing great quantities of deep yellow flowers. Entirely distinct.

\section{HELIOPSIS - False Sunflower}

This family of False Sunflowers is closely related to the preceding group and may be used for the same purposes, supplying lower, denser-growing subjects than in helianthus. It is very useful for that reason, and striking effects may be obtained by large-scale planting.

Heliopsis helianthoides (lævis). Sunflower Heliopsis. 3 to $5 \mathrm{ft}$. July to October. An erect, robust plant, producing fine heads of golden yellow flowers. H. helianthoides pitcheriana. Pitcber Heliopsis. 2 to $3 \mathrm{ft}$. July to October. A choice dwarf variety with deep orange-yellow flowers of great value for cutting all through the summer. Especially good for dry situations.

H. helianthoides pitcheriana semi-plena. $21 / 2$ to $3 \mathrm{ft}$. July to October. Semi-double form of the above, with curious, narrow petals of the same orange color issuing from the center of the flowers. 90 cts. for 3 , $\$ 2.40$ for 10 .

\section{HEMEROCALLIS • Day Lily}

Much attention has been paid of late to improving the Day Lilies, and now a proper selection of varieties will enable one to have them in flower the greater part of the season. They are very decorative, with their ribbon-like foliage and their beautiful lilylike flowers, especially when grown in clumps at prominent places in the border. The pale lemon types are lovely with light blue flowers such as Belladonna delphiniums, and soft magenta or mauve tones find a happy combination with them. The richer yellow flowers give opportunity for combinations with darker blues and purples, as well as bolder, tawnier flowers. They are very hardy, very persistent, and make permanent borders when established.

Hemerocallis aurantiaca major. Great Orange Das Lily. $11 / 2$ to $2 \mathrm{ft}$. June to September. A splendid variety from Japan, with large, trumpet-shaped, sweetly scented flowers of deep orange. $\$ 1.05$ for $3, \$ 3$ for 10

H. citrina. Citron Day Lilv. $3 \mathrm{ft}$. June and July. A broad-leaved sort with very fragrant long flowers of pale sulphur-yellow, borne on tall, graceful stems. Highly desirable for cutting.

H. dumortieri. Earlv DavLilv. $11 / 2$ to $2 \mathrm{ft}$. May and June. Rich cadmium-yellow buds and reverse of petals bronze-yellow.

H. dumortieri sieboldi (Blooms three weeks after Dumortieri). $11 / 2$ to 2 it. June and July. Flowers orange-yellow; large leaves, Iong, narrow and tapering.

H. flava. Lemon Day Lily. $3 \mathrm{ft}$. May and June. Flowers clear lemon-yellow and very fragrant. Fine for cutting. Charming in masses on the banks of streams and in clumps in border or rock garden. $\$ 1.20$ for 3 , $\$ 3$ for $10, \$ 24$ per 100 .

H. fulva. Tawny Day Lily. $3 \mathrm{ft}$. June and July. Handsome foliage with trumpet-shaped flowers of dusty orange with darker, almost crimson, shading. Attractive in semi-wild spots on the edge of water. A very vigorous and persistent plant. 75 cts. for 3 , $\$ 2.20$ for $10, \$ 16$ per 100

H. gracilis. $2 \mathrm{ft}$. Grass-like foliage, yellow flowers. $\$ 1.05$ for 3, \$2.70 for 10, \$20 per 100 .

H. luteola. Golden Day Lily. $4 \mathrm{ft}$. Golden yellow flowers 6 inches across. A splendid variety which is effective both in the garden and when cut. $\$ 1.20$ for $3, \$ 3$ for $10, \$ 21$ per 100 .

H. middendorffi. A mur Day Lily. 2 to $3 \mathrm{ft}$. June and July. Handsome golden orange flowers especially good for cutting.

H. thunbergi. Japanese Day Lily. $3 \mathrm{ft}$. July. Rich, clear buttercup-yellow, sweet-scented flowers.

New Varieties. We are the introducers of Betscher's remarkable Hemerocallis Hybrids. Described and offered on page 68.

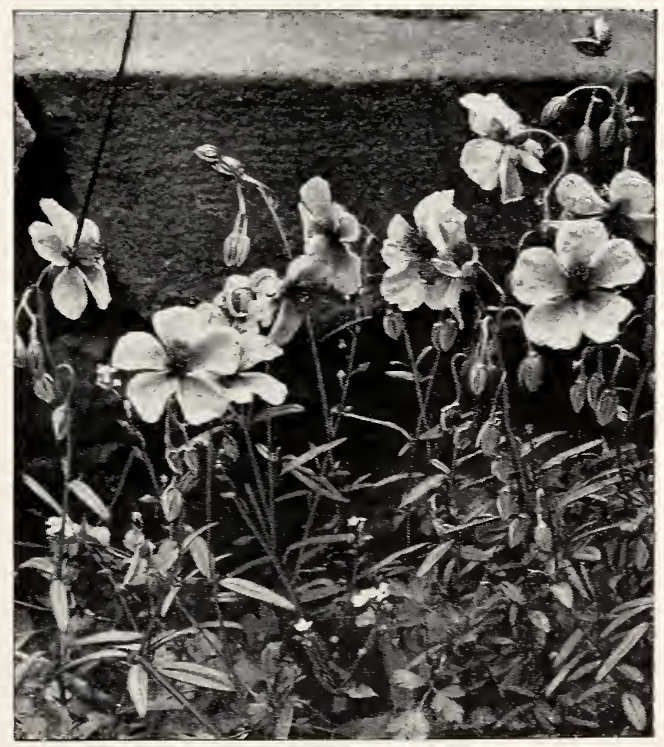

Helianthemums in a rock garden 


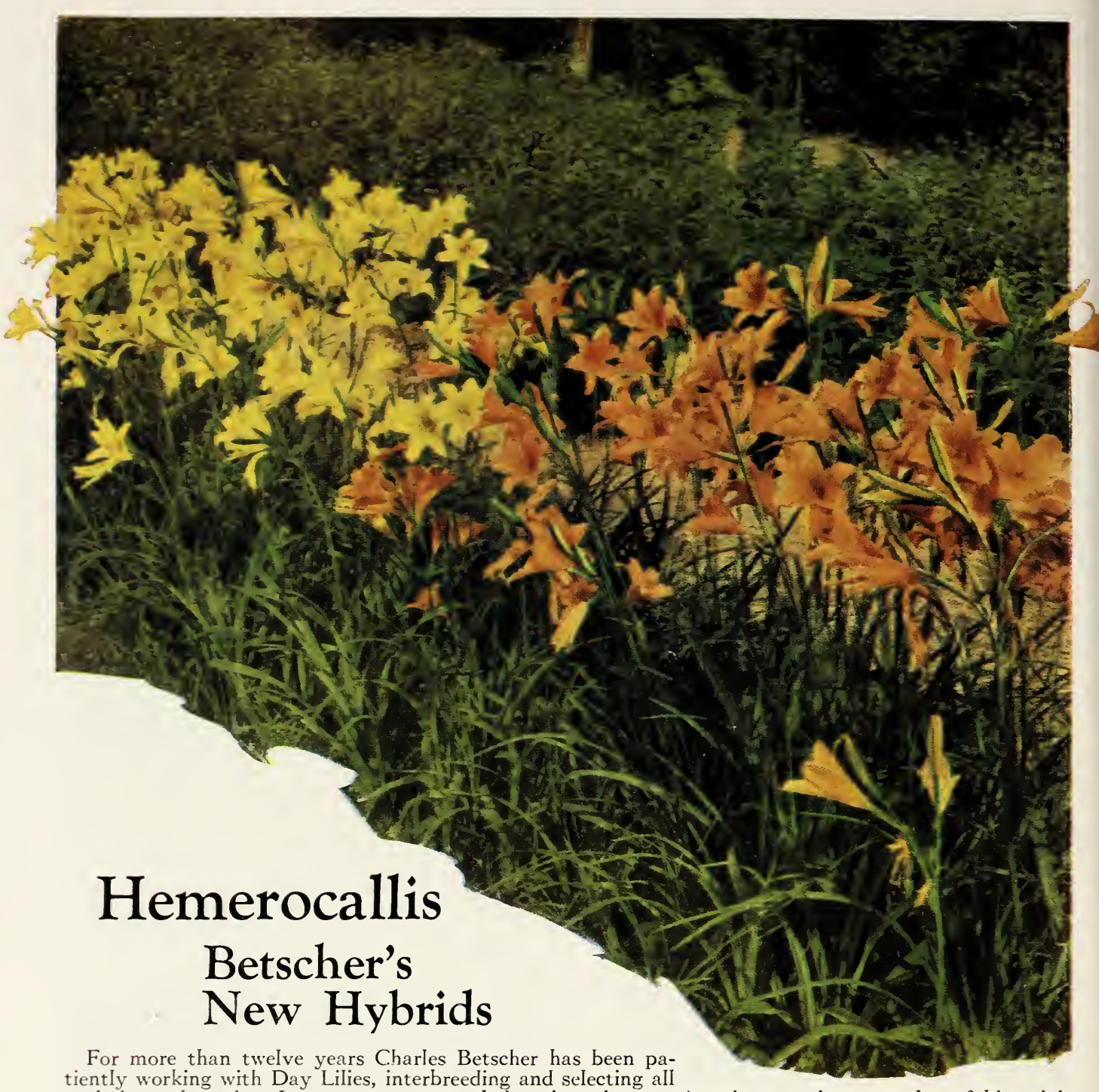

tiently working with Day Lilies, interbreeding and selecting all

varieties and species. Last year we were glad to introduce to American gardeners twelve of his originations which he selected, and three of which he named for us.

We have been growing them in our nursery for over three years, and we are just as enthusiastic about them now as when we first saw them. Last year we offered them for sale for the first time and had an excellent demand for them. Visitors who saw them in our nursery were particularly interested in them. We trust that you will be able to come to our nursery and see them this summer.

We can supply strong plants of the varieties described at $\$ 2.50$ each, $\$ 22.50$ for 10

Bay State. Tall variety with deep yellow blossoms a shade lighter than Goldeni, and having wavy edge. A persistent bloomer from early July to middle August.

Cressida. A lovely deep reddish orange with narrow band across center. It is of medium height, with heavy foliage, and blooms from middle of July to middle of August.

D. D. Wyman. Light golden yellow at first, with a tawny splash across center of petal, becoming paler with maturity. Blooms from July 10 to early August. Goldeni. A bushy sort with heavy foliage and deep orange flowers on short stems in July.

Gypsy. Orange-yellow blooms not quite so large as some of the other varieties. Very tall and strong; neat in appearance. This past year it bloomed from July 9 to August 20.

Harvest Moon. Plants of medium height. Flowers with long, slender petals of clear orange-sherbet color appear in July.

J. A. Crawford. Very open, apricot-yellow blossoms appearing early in July. Plant of medium height.

Lemona. A splendid pale lemon-yellow which grows about 4 feet high and blooms in late July and into August.

Modesty. Medium to Iarge, pale yellow blooms on slender stems from middle to late July.

Mrs. A. H. Austin. Handsome, large flowers of deep golden yellow. Very fine variety which blooms over a long period beginning about July 10 .

Mrs. W. H. Wyman. A wonderful sort and the very last to bloom. About same height as Lemona but just a shade lighter. Blooms from mid-July to latter part of August.

The Gem. Deep yellow blossoms of very fine substance, wavy edge. Medium height; light foliage. One of the first to bloom. 


\section{Hybrid Hemerocallis}

These are all highly improved sorts, with purer color and flowers of higher finish than the species. Very splendid garden pictures can be made by placing them in appropriate locations. They look especially weIl near pools, although they are in no sense water-plants. A remarkable, new set of varieties is offered on preceding page.

Apricot. $2 \mathrm{ft}$. A very pretty clear bright orange flower of excellent size and finish. $\$ 1.05$ for $3, \$ 2.70$ for 10 , $\$ 20$ per 100 .

Aureole. $3 \mathrm{ft}$. May and June. A splendid early sort of rich orange-yellow.

Betscher's Hybrids. See preceding page.

Dr. Regel. $1 \frac{1}{2} \mathrm{ft}$. May and June. A very fragrant sort of pure orange-yellow. One of the finest named sorts and excellent for cutting.

Gold Dust. $2 \mathrm{ft}$. June. Very Iarge, golden yellow flowers.

Kwanso flore-pleno. 2 to $3 \mathrm{ft}$. June and July. Double flowers of rich orange-copper.

Orangeman. $3 \mathrm{ft}$. June and July. Very large flowers of bright orange-yellow.

\section{HEPATICA}

*Hepatica acutiloba. Sharplobe Hepatica. 6 in. April and May. The flowers vary from pure white to purple and into shades of pink. It has leathery, three-lobed Ieaves resembling the following, but lobes more pointed.

*H. triloba. Roundlobe Hepatica. 6 in. Late April and early May. Flowers white, dark rose, or purple. Good for eastern and northern exposures in the rock garden and shady places generally.

\section{HESPERIS - Rocket}

*Hesperis matronalis. Dame's Rocket. 2 to $3 \mathrm{ft}$. June and July. Fragrant purple flowers in showy spikes. Desirable for wild garden, shrubbery, or mixed border.

*H. matronalis alba. Wbite Dame's Rocket. Same height and season as above, but showy terminal spikes of white flowers.

\section{HEUCHERA • Alum-Root}

Abroad, these pretty perennials are called "Fairy Flowers," a name they deserve for their delicacy and grace. They make handsome rosettes or mats of good-looking leaves from which rise slender, swaying stems bearing showers of tiny bells. They look weIl about a sun-dial, at the edge of a pool, or planted among rocks, or in the perennial border. The descriptions of the many kinds sound much alike, but they have a varied charm and aII are beautiful in their different ways.

*Heuchera brizoides. Pink Bells. $1 \mathrm{ft}$. June to August. Pale pink flowers on slender red stems. A very interesting plant because of its bigeneric origin, being a variety of Tiarella. $\$ 1.05$ for $3, \$ 2.70$ for 10 , $\$ 24$ per 100

*H., Hybrids. $11 / 2 \mathrm{ft}$. Plants of similar habit and flowers of various shades of best red. Twice as I arge as $H$. sanguinea. $\$ 1.05$ for $3, \$ 2.70$ for $10, \$ 24$ per 100.

*H., Perry's White. 1 to $2 \mathrm{ft}$. May to September. A charming pure white variety of unusual grace. $\$ 1.50$ for $3, \$ 4.50$ for 10 .

H., Rosamundi. A very strong grower, producing an abundance of taII, strong stems crowned with intense coral-pink flowers in great profusion, which last over two months. Finest of the pink varieties. $\$ 1.20$ for $3, \$ 3$ for $10, \$ 24$ per 100 .

*H. sanguinea. Coral Bells. 12 to 18 in. June to September. A splendid border or rock plant with big rosettes of leaves from which rise clusters of slender stems bearing showers of tiny crimson bells. Pretty for cutting and excellent for the rock garden. $\$ 1.05$ for $3, \$ 2.70$ for $10, \$ 24$ per 100 .

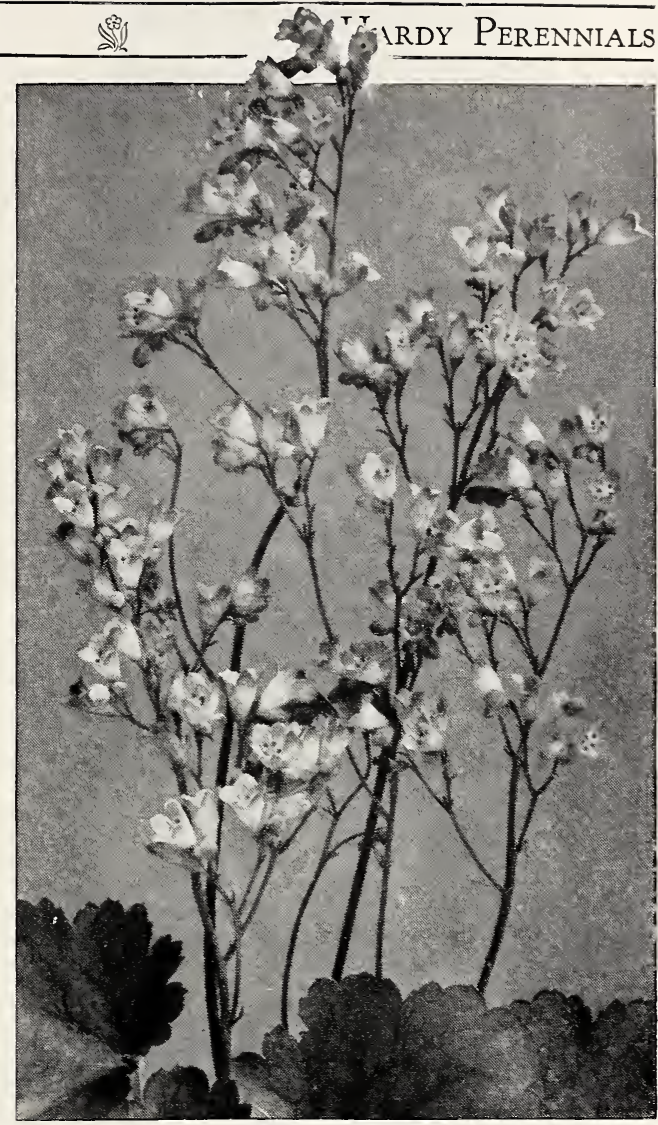

Heuchera sanguinea

HEUCHERA, continued

*H. sanguinea alba. White Coral Bells. A variety of the above having white flowers.

*H. sanguinea gracillima (gracilis rosea). Grassleaf Coral Bells. A slender and even more dainty plant than $H$. sanguinea. Suited to similar situations. $\$ 1.05$ for $3, \$ 2.70$ for $10, \$ 24$ per 100 .

*H., Splendens. Crimson Bells. 18 in. May to September. A very rich, dark crimson form which blooms over a very long season. $\$ 1.05$ for $3, \$ 2.70$ for $10, \$ 24$ per 100 .

\section{HIERACIUM}

Hieracium aurantiacum. Orange Hawkweed. 6 to 12 in. June to October. A low herb, producing small clusters of dandelion-like orange flowers, on leafless stems, rising from tufts of shaggy foliage. Good ground-cover for sterile waste land or wild garden. *H. pilosella. Yellow Hawkweed. 4 to 12 in. Bloom all season. Plant creeping or spreading; rough foliage; flowers pale yellow, sometimes tinged with purple. A quick ground-cover.

\section{HIBISCUS • Rose Mallow}

The native Mallows are almost aIl swamp plants, but their garden forms seem to thrive well in dry places. They are big and bold, almost shrub-like, and look weIl against a shrub background. As they come up very Iate in the spring, their positions ought to be marked so that they will not be overlooked and cut with the hoe or other cultivating tools.

Hibiscus militaris. Soldier Rose Mallow. $5 \mathrm{ft}$. August. A strong-growing plant, with small leaves and large blush or pale rose flowers with purple eye. 


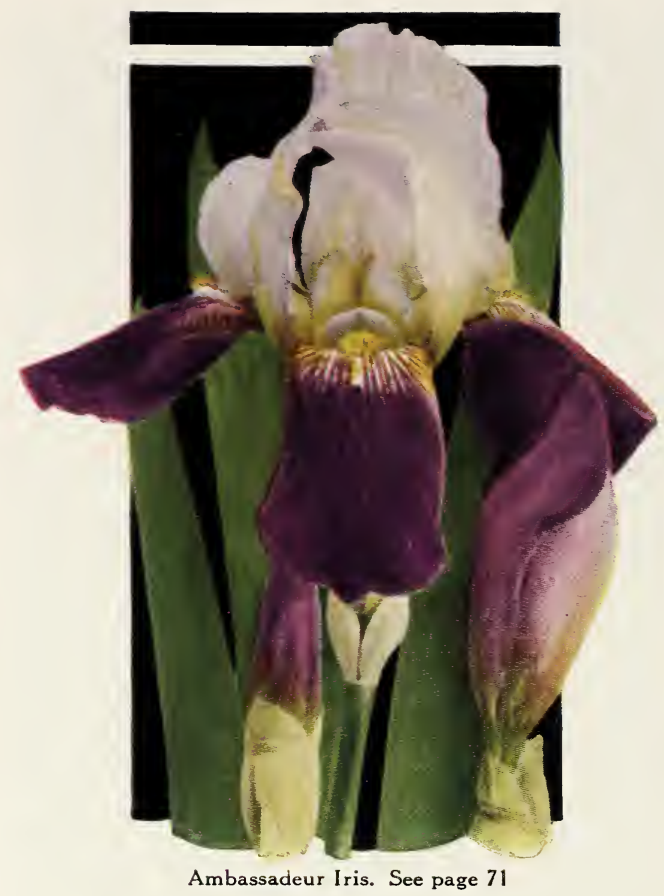

HIBISCUS, continued

H. moscheutos. Common Rose Mallow. 3 to $4 \mathrm{ft}$. August and September. Large flowers of light rosered. Excellent for water edge or bog-garden.

H. moscheutos, Marvel Mallows, Red, White, Pink, and Mixed. 3 to $6 \mathrm{ft}$. August and September. Robust plants with giant flowers often 10 to 12 inches in diameter, of varying shades from white to dark red. Useful in shrub border to give color when the shrubs are out of flower, but highly decorative in any situation. They do weIl in almost any location, but enjoy moisture at the root. Few plants are more spectacular.

H. oculiroseus. Crimson-Eye Rose Mallow, 3 to $6 \mathrm{ft}$. August and September. A similar plant to $H$. moscbeutos but has very Iarge snow-white flowers with a quiet crimson center. Very showy and does well in almost all locations, even very wet ones.

\section{HOLL YHOCKS. See Althæa}

\section{HOSTA (Funkia) • Plantain Lily}

Shade-loving plants that look well just at the edge of a heavy shrub border, or along shady paths. The flowers are like small, clustered lilies and rise on tall stems above the big, glossy leaves. Decorative in or out of flower.

Hosta cærulea. Blue Plantain Lily. 1 to $2 \mathrm{ft}$. July and August. Pretty masses of shiny foliage and deep violet-blue flowers on spreading stems.

H. lancifolia. Lance-leaf Plantain Lilv. $2 \mathrm{ft}$. August. Spikes of pale lilac flowers; deep green narrow foliage.

H. lancifolia albo-marginata. Silver-edge Lanceleaf Plantain Lily. 1 to $2 \mathrm{ft}$. A fine foliage plant with handsome leaves, variegated with white. One of the best for edging.

H. lancifolia undulata variegata. Wavy-leaf Plantain Lilv. $1 \mathrm{ft}$. June and July. Fine variegated foliage and blue flowers. Very attractive for border. H. ovata. $11 / 2 \mathrm{ft}$. June. Large, handsome, glossy green foliage and big spikes of trumpet-shaped, lilac-colored flowers. $\$ 1.20$ for $3, \$ 3$ for $10, \$ 24$ per 100 .

H. plantaginea grandiflora. Big Plantain Lily. This is the variety found in old gardens and yards, with big ribbed leaves and tall stems of waxy white flowers. $50 \mathrm{cts}$. each, \$4.50 for $10, \$ 39$ per 100 .

H. sieboldiana. Cusbion Plantain Lily. Flowers pale blue and leaves metallic blue. \$1.20 for 3, $\$ 3.50$ for $10, \$ 30$ per 100 .

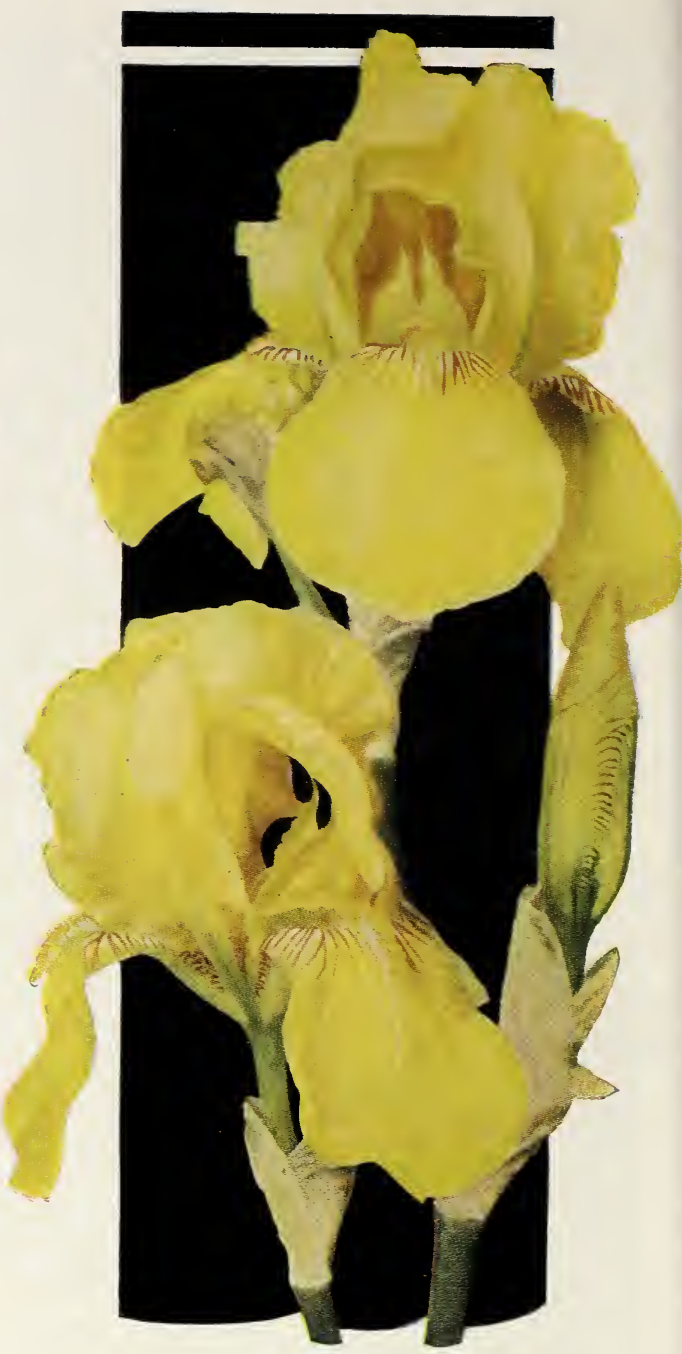

Shekinah Iris. See page 73

\section{HYPERICUM}

*Hypericum repens. 4 to 6 in. A creeping plant with dark foliage and bright yellow flowers $11 / 2$ inches in diameter. A wonderful little plant. $\$ 1.20$ for 3 , $\$ 3.50$ for $10, \$ 25$ per 100 .

\section{HYSSOPUS}

*Hyssopus officinalis. Hyssop. 1 to $2 \mathrm{ft}$. June to August. Aromatic shrubby herb of culinary and medicinal value with bluish purple flowers in leafy spikes. Good for edging and can be trimmed like box.

*H. officinalis rosea. A seedling variety which originated in our frelds. Similar to the species but the flowers are pink.

Iberis and Incarvillea will be found on page $\mathbf{7 4}$

\section{INULA}

*Inula ensifolia. Swordleaf Inula. 6 to 8 in. July and August. A narrow-leaved sort with large, bright yellow flowers. Showy for a bold clump in the rockery. $\$ 1.20$ for $3, \$ 3$ for $10, \$ 24$ per 100

I. glandulosa. Caucasian Inula. $11 \frac{1}{2}$ to $2 \mathrm{ft}$. July. Large, bright yellow, aster-like flowers with fringed petals. A good border plant.

I. salicina. Willowleaf Inula. $2 \mathrm{ft}$. July and August. A vigorous variety producing a profusion of pretty yellow flowers. 


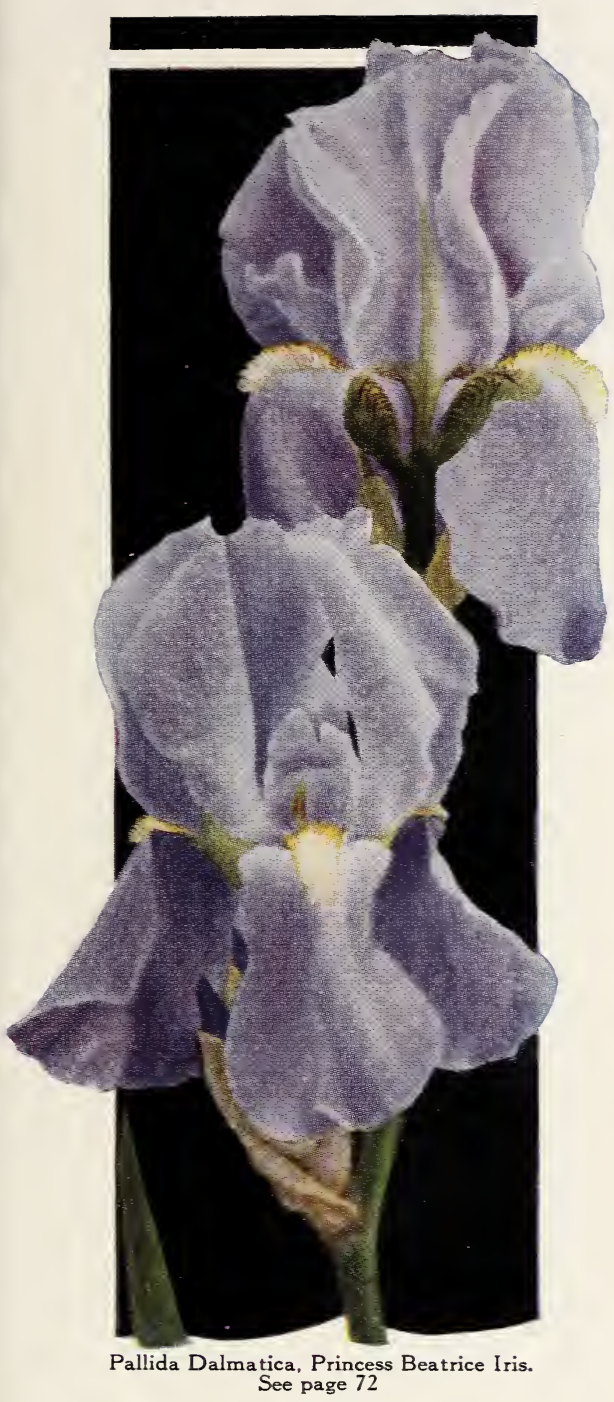

IRIS

Irises appeal both to the connoisseur who enjoys their delicacy of texture, beauty of form, and the exquisite colorings, ever modified by the interplay of light, shadows, and reflections within the complexity of the flower, but also to the "quick and easy" back-yard gardener because of their everlasting willingness to grow anywhere and bloom their heads off without any attention at aII.

They rank among the most important of all plants and share the top of the perennial list only with the peony.

We have upward of one hundred and fifty varieties in our collection, including all classes in both named varieties and separate colors.

\section{German Iris - Tall Bearded Iris}

This class of Iris is particularly adapted for the wildgarden, shrubbery border, or any well-drained garden soil. They bloom early and their variety of color is infinite. Very useful for cutting, the buds opening rapidly in water.

The following list includes many old varieties with certain characteristics that make them still greatly desirable, and we have added a number of newer

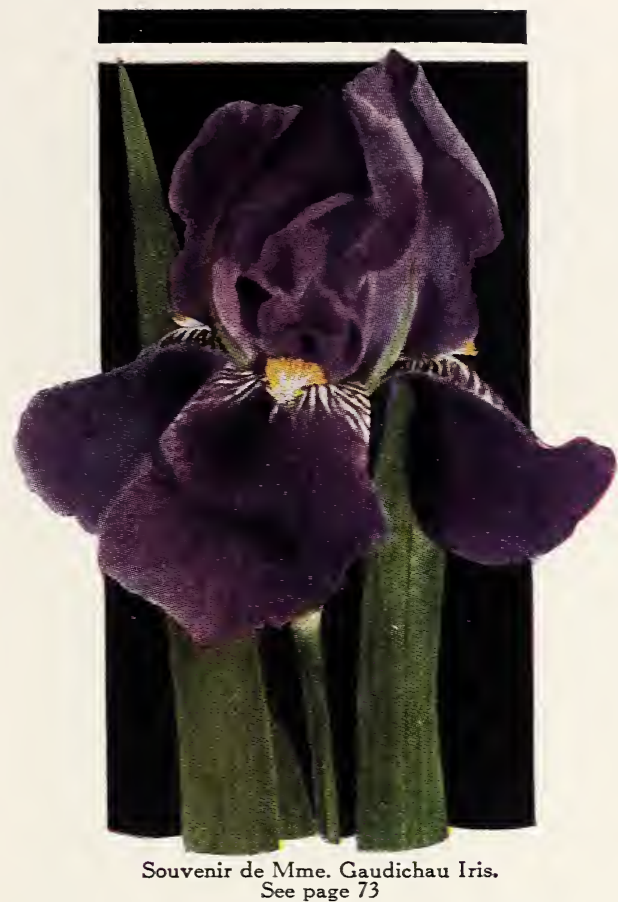

varieties of real value. The figures which follow the names of the originators denote the rating according to the symposium of the American Iris Society, published in May, 1922.

They should be planted in full sunlight, in welldrained soil, and it is conceded that a little lime now and then is beneficial. There is considerable prejudice among Iris fanciers against using manure, and fertilization is usually accomplished by the use of bone-meal or some commercial product.

Admiral Togo. White, faintly tinted Iavender; F. and S. Iightly bordered purple; of the habit of Mime. Chereau. 30 cts. each, \$2.40 for $10, \$ 18$ per 100.

Afterglow. (Sturtevant, 1917.) 8.6 Soft grayish pink, shading to rich yellow through the center. $3 \mathrm{ft}$. $75 \mathrm{cts}$. each.

Alcazar. (Vilmorin, 1910.) 8.9 S. Iight bluish violet; F. deep purple, with bronze-veined throat. 3 to $4 \mathrm{ft}$. 40 cts. each, \$3 for $10, \$ 27$ per 100

Amas. (Foster, 1885.) 7.8 S. rich bue; F. violet very large, beautifuI flower. $2 \mathrm{ft}$. $40 \mathrm{cts}$. each, $\$ 3.50$ for 10 .

Ambassadeur. (Vilmorin, 1920.) 9.4 S. Iavender with smoky stains and crystalline texture; F. glorious purple with a silky velvety sheen of glowing crimson. One of the tallest, largest, and most beautiful Irises in the world. 60 cts. each, $\$ 5$ for 10 .

Archeveque. (Vilmorin, 1911.) 8.3 S. deep purpleviolet; F. deep velvety violet. $2 \mathrm{ft}$. $50 \mathrm{cts}$. each, S4 for 10 .

Atroviolacea. (Salter, before 1859.) S. violet-blue; F. deep purple. 30 cts. each, \$2.40 for $10, \$ 18$ per 100 . Attraction. (Sir Robert PeeI, 1885.) S. pale blue; F. darker blue, penciled white on lower half; anthers white, tipped yellow. 30 cts. each, $\$ 2.40$ for $10, \$ 18$ per 100.

Augustina. Tbunbergian. S. yellow: F. rellow and maroon. 30 cts. each, $\$ 2.40$ for $10, \$ 18$ per 100 .

Aurea. (Jacques, 1830.) S. and F. rich chrome-yellow. Large flowers of perfect form. $35 \mathrm{cts}$. each, \$3 for $10, \$ 24$ per 100

Canary Bird. (Barr, 1910.) S. canary-yellow; F. crimson-purple; very distinct. $30 \mathrm{cts}$ each, $\$ 2.40$ for 10, S18 per 100 .

Candelabre. (Vilmorin, 1911.) 6.6 S. pale Iavenderviolet, flecked darker at base; $F$. velvety purple, densely veined. $2 \mathrm{ft}$. $30 \mathrm{cts}$. earh, $\$ 2.40$ for 10 , S18 per 100.

Caprice. (Vilmorin, 1898.) 7.5 S. rosy red; F. deeper rosy red. 35 cts. each, \$3 for $10, \$ 24$ per 100 . 


\section{GERMAN IRIS, continued}

Cecil Minturn. (Farr, 1922.) S. light lavenderpink; F. pale purple, center violet stained, and illumined by a golden beard. Medium-sized flower on stems 27 in. high. A wonderful "pink" Iris for specimen clumps or broad landscape effect. 60 cts. each, $\$ 5$ for 10 .

Charles Dickens. (1889.) S. blue; F. dark blue, suffused and veined dark violet; anthers white, tipped yellow. 30 cts. each, $\$ 2.40$ for $10, \$ 18$ per 100 .

Cherubim. (Vilmorin, 1911.) 6.8 S. pinkish violet or mauve; F. rosy lavender, veined darker. $30 \mathrm{cts}$. each, $\$ 2.40$ for 10 , \$18 per 100 .

Darius. (Parker, 1873.) S. chrome-yellow; F. purple, margined pale yellow and reticulated white. $30 \mathrm{cts}$. each, $\$ 2.40$ for $10, \$ 18$ per 100 .

Eldorado. (Vilmorin, 1910.) 7.8 S. bronzy yellow stained mauve; F. violet and yellow-bronze. $21 / 2 \mathrm{ft}$. 30 cts. each, \$2.40 for $10, \$ 18$ per 100 .

Flavescens. (De Candolle, 1813.) S. and F. creamy white and pale yellow; very fragrant. Free blooming. Early. 30 cts. each, \$2.40 for $10, \$ 18$ per 100 .

Florentina alba. (Italy, 1500.) Creamy white, with a faint lavender cast. A variety of the following and both bloom very early in the season. $30 \mathrm{cts}$. each, $\$ 2.40$ for 10 , \$18 per 100 .

Florentina, Blue (Iris germanica). S. and F. blue; fragrant, free bloomer. 30 cts. each, $\$ 2.40$ for 10 , $\$ 18$ per 100.

Garrick. (Caparne, 1901.) S. lilac; F. dark violetblue. 30 cts. each, $\$ 2.40$ for $10, \$ 18$ per 100 .

Gen. Grant. (Dutch, 1889.) S. pale lemon; F. purple, striped white on the lower half, narrowly bordered with Iemon. 30 cts. each, \$2.40 for $10, \$ 18$ per 100.

Gold Imperial. (Sturtevant, 1924.) S. and F. rich golden yellow, intensified by a bright orange beard. Flower of medium size on tall stems, 33 inches. One of the rare choice Irises. Good, pure yellow varieties are very scarce. $\$ 1.25$ each, $\$ 10$ for 10 .

Hector. (Lemon, 1840.) S. dark blue; F. purple. 30 cts. each, $\$ 2.40$ for $10, \$ 18$ per 100 .

Her Majesty. (Perry, 1903.) 7.3 S. rose-pink; F. bright crimson, shaded darker. 22 in. 35 cts. each, \$3 for 10, \$21 per 100 .

Herant. (1889.) S. bright bue; F. much deeper in color. A beautiful broad-leaved sort; very earlyflowering. $30 \mathrm{cts}$. each, $\$ 2.40$ for $10, \$ 18$ per 100 .

Horatius. S. buff, shaded blue; F. blue, veined deeper blue and chocolate. 30c. each, \$2.40 for $10, \$ 18$ per 100 .

Iris King. (Goos \& Koenemann, 1907.) $7.9 \mathrm{~S}$. Iemon-yellow; F. rich maroon, bordered yellow. $22 \mathrm{in}$. 35 cts. each, \$3 for 10

Isoline. (Vilmorin, 1904.) 8.6 S. rosy lilac; F. darker, veined brown at the base, with a bright orange beard. Tall, very large, and the falls carried in unique style. Very fine. 25 cts. each, $\$ 2.20$ for $10, \$ 15$ per 100 .

Johan de Witte. S. light lilac-blue; F. purple. 30 cts. each, $\$ 2.40$ for $10, \$ 18$ per 100 .

Juniata. (Farr, 1909.) $8.1 \mathrm{~S}$. and F. clear blue. Large, fragrant flowers. 44 in. 35 cts. each, $\$ 3$ for $10, \$ 24$ per 100.

Kochi. S. and F. dark, rich purple, very broad and large. An excellent early sort 12 to 18 inches high. 30 cts. each, $\$ 2.40$ for 10 , \$18 per 100 .

Lent A. Williamson. (Williamson, 1918.) 9.0 S. mysterious lavender-violet with silky sheen; F. velvety purple with a dull blackish shadow and rich velvety texture. Center brightened by a showy gold-orange beard. One of the finest Irises in existence. Flowers very large on stems 4 feet high. 60 cts. each, $\$ 5$ for 10 .

Lohengrin. (Goos \& Koenemann, 1910.) 8.2 S. and F. light Iilac-pink with a soft, silvery sheen. Strong, erect stems. Very handsome. $35 \mathrm{cts}$. each, $\$ 3$ for 10 $\$ 25$ per 100.

Lord of June. (Yeld, 1911.) 9.1 S. light silvery blue; F. darker, marked with brown at the base. Very Iarge, stately flowers on tall stems. One of the most beautiful of all Irises. $60 \mathrm{cts}$. each, $\$ 5$ for 10.

Loreley. (Goos \& Koenemann, 1909.) 7.9 S. light vellow; F. deep sea-blue, with creamy edging. 32 in. 35 cts. each, $\$ 2.70$ for 10 , \$20 per 100 .
Loute. (Vilmorin, 1904.) 6.8 S. light mauve with an overlay of bronze; $F$. reddish violet. Large. 35 cts. each, $\$ 3$ for $10, \$ 27$ per 100 .

Malvina. (Lemon, 1857.) S. yellow, blotched with brown; F. rich purple, flecked with white, the middle striped white, base tinted yellow. 30 cts. each, $\$ 2.40$ for $10, \$ 18$ per 100

Mexicana. (Salter, before 1859.) S. yellow, suffused with old-gold on the tips; F. purple, tipped old-gold with yellow base. 30 cts. each, $\$ 2.40$ for $10, \$ 18$ per 100.

Midnight. A rich velvety dark purple. 28 in. $30 \mathrm{cts}$. each, \$2.40 for 10 , \$18 per 100 .

Mme. Chereau. (Lemon, 1844.) S. and F. white, edged and feathered with violet and pale blue. Very free. 30 cts. each, $\$ 2.40$ for $10, \$ 18$ per 100 .

Monsignor. (Vilmorin, 1907.) 8.4 S. pale violet; F. with a groundwork of the same color but richly overlaid and veined with deep purple. 28 in. $50 \mathrm{cts}$. each, $\$ 4$ for 10 .

Mother of Pearl. (Sturtevant, 1921.) S. and F. pale bluish lavender with a faint creamy undertone. Large flowers of exceptional substance and perfect form on well-branched stems. $75 \mathrm{cts}$. each, $\$ 6$ for $10, \$ 50$ per 100.

Mrs. Horace Darwin. (Foster, 1903.) 6.8 S. pure white; F. slightly reticulated violet at the base. $2 \mathrm{ft}$. 30 cts. each, $\$ 2.40$ for $10, \$ 18$ per 100 .

Niebelungen. (Goos \& Koenemann, 1910.) 7.3 S. fawn-yellow; F. violet-purple on bronze. Large. $21 / 2 \mathrm{ft}$. 35 cts. each, $\$ 2.70$ for $10, \$ 20$ per 100 .

Nuee d'Orage. (Verdier, 1905.) 7.6 S. pale mauve or slate-color; F. reddish purple. Free-flowering. $3 \mathrm{ft}$. 30 cts. each, \$2.40 for 10, \$18 per 100 .

Oroya (Charles Dickens). S. purple; F. purple, penciled white and mauve; limb purple, splashed with darker shade. 30 cts. each, \$2.40 for $10, \$ 18$ per 100 .

Pallida Dalmatica, Princess Beatrice. True Pallida Dalmatica, and still one of the most attractive varieties as well as most satisfactory. Large flowers of a clear lavender-blue, shading to a pale silvery blue at the base, and sweetly scented. $40 \mathrm{cts}$. each, \$3 for 10, \$24 per 100.

Parc de Neuilly. (Verdier, 1910.) 8.1 Flowers rich plum-purple; S. arching, ruffled; F. drooping. $21 / 2 \mathrm{ft}$ 50 cts. each, \$4 for 10.

Parisiana. (Vilmorin, 1911.) S. white, dotted with rosy purple; $F$. white, edged with violet. $30 \mathrm{cts}$. each, $\$ 2.40$ for $10, \$ 18$ per 100 .

Pauline. (Farr, 1913.) S. bright bue; F. dark blue. 30 cts. each, $\$ 2.40$ for $10, \$ 18$ per 100 .

Perfection. (Barr.) 7.8 S. light blue; F. velvety purple-black, with conspicuous orange beard. $3 \mathrm{ft}$. 35 cts. each, \$3 for 10, \$21 per 100 .

Pocahontas. (Farr, 1915.) 7.7 S. and F. pure white, with S. faintly bordered pale blue. 28 in. 50 cts. each.

Princess Victoria Louise. (Goos \& Koenemann, 1910.) 7.2 S. sulphur-yellow; F. rich plum, bordered cream. $21 / 2 \mathrm{ft}$. $35 \mathrm{cts}$. each, $\$ 2.70$ for $10, \$ 20$ per 100 .

Prosper Laugier. (Verdier, 1914.) 8.3 S. light bronzered; F. deep velvety crimson, richly veined at the throat. 35 cts. each, $\$ 2.70$ for $10, \$ 20$ per 100 .

Purple King. A bright purple. 30 cts, each, $\$ 2.40$ for 10, \$18 per 100 .

Quaker Lady. (Farr, 1909.) 8.4 S. smoky Iavender with yellow shading; $F$. ageratum-blue and oldgold. 32 in. 40 cts. each, $\$ 3.50$ for $10, \$ 30$ per 100.

Queen Caterina. (Sturtevant, 1918.) 9.1 S. and F. light, silvery blue, with a very faint lavender tinge, veined bronze in the heart of the flower, and bearing a rich orange beard. 40 cts. each, $\$ 3.50$ for 10 , \$27 per 100.

Queen of May. (Salter, before 1859.) S. most delicate rose-pink. 30 cts. each, \$2.40 for 10 , \$18 per 100 .

Rebecca. (Lemon, 1840.) S. golden yellow; F. yellow, splashed and veined golden brown. 30 cts. each, $\$ 2.40$ for $10, \$ 18$ per 100 .

Rhein Nixe. (Goos \& Koenemann, 1910.) 8.4 S. pure white; F. deep violet-blue with white edge. $3 \mathrm{ft}$. 35 cts. each, $\$ 3$ for $10, \$ 21$ per 100 . 


\section{GERMAN IRIS, continued}

Shekinah. (Sturtevant, 1918.) 8.8 S. and F. pale lemon-yellow, shading to buff and straw-color, and a strong orange beard. A fine tall plant and one of the very few good, tall yellow varieties. $50 \mathrm{cts}$. each, S4 for 10 .

Sherwin-Wright. (Kohankie, 1915.) 7.6 Fine golden yellow; vigorous grower. $2 \mathrm{ft}$. $35 \mathrm{cts}$. each, $\$ 3$ for $10, \$ 24$ per 100.

Souvenir de Mme. Gaudichau. (Millet, 1914.) 9.3 A splendid early variety of rlear, distinct bluepurple, very dark and fine. Excellent substance and tall stems. S1 each, \$8 for 10 .

Speciosa. (Old French, before 1830.) S. dark lavender; F. light purple. 30 cts. each, $\$ 2.40$ for 10 , $\$ 18$ per 100 .

St. Clair. (Lemon, 1854.) S. and F. white, with welldefined blue borders half an inch wide. One of the best. $3 \mathrm{ft}$. 30 cts. each, $\$ 2.40$ for 10 , \$18 per 100.

Striata. S. pure yellow; F. white, with yellow border penciled dark brown. 30 cts. each, $\$ 2.40$ for 10 , \$18 per 100 .

Swerti. (Ancient, before 1612.) White bordered light blue; tall and late. Similar to St. Clair but smaller in all its parts. 30 cts. each, $\$ 2.40$ for 10 , $\$ 18$ per 100.

Violetta. (Dykes, 1921.) S. white; F. blue, striped Iavender. 30 cts. each, $\$ 2.40$ for $10, \$ 18$ per 100 White Knight. (Saunders, 1916.) 8.3 A beautiful absolutely pure white variety without markings; well formed: sweet-scented. 18 in. 35 cts, each, \$3 for 10

William III. (Amas.) (Col. by Foster, 1885.) Dark violet, very large flower; late and beautiful; very fragrant. 30 cts. each, \$2.40 for $10, \$ 18$ per 100 .

\section{Iris kaempferi · Japanese Iris}

Extremely showy plants, bearing enormous, flat, salver-like flowers in many shades of white, lavender. purple, violet, blue, and beautifully veined types. They bloom about one month after the German Iris varieties, usually in mid-July.

They like a moist, wet spot and full sun, but do well in dry soil, if plenty of water is supplied at bloomingtime. This is one of the finest groups of perennials. They are so distinct from other Irises that they seem to belong to a different family.

Prices of Japanese Iris, except where otherwise noted are $50 \mathrm{cts}$. each, $\$ 4$ for $10, \$ 36$ per 100 . We wil furnish 10 named Japanese Iris of our own selection for \$4-all good varieties (10 named Japanese Iris, your selection, would cost $50 \mathrm{cts}$. each).

Alida. White, six-petaled variety, with stripe of light blue.

Aspasie. (Vilmorin, 1905.) Single; soft mauve-blue

Astarte. (Vilmorin, 1903.) Double; beautiful dark violet.

Babylon. (Hallock, 1889.) Reddish purple; very rich color; extra-large flowers.

Band of Clouds. (Kumo-no-Obi.) Bright clear purple with distinct rays and halo of white surrounding the golden throat.

Blue Belle. Beautiful deep blue, yellow center; Iate.

Blue Bird. (Hallock, 1889.) Intense blue throughout; large and full.

Blue Danube. (Hallock, 1889.) Pure rich blue, yellow center; six petals.

Commodore Perry. Very dark violet-red; six petals; medium size.

Double Blue Belle. Beautiful, double, deep blue flowers; very late.

Gold Bound. (Hallock, 1885.) Large white flowers, yellow center; six petals.

Harlequin. (Elliott.) Whitish Iavender; Iarge.

Helen Von Siebold. Deep pink, white lines.

Hercules. (Vilmorin, 1910.) Light blue, shaded with violet.

Iso-no-Nami. Cerulean-blue on gray-lilac, flaked and speckled, large yellow blotches; six petals.

Kamaochi-guma. Dark purplish indigo; midseason double.

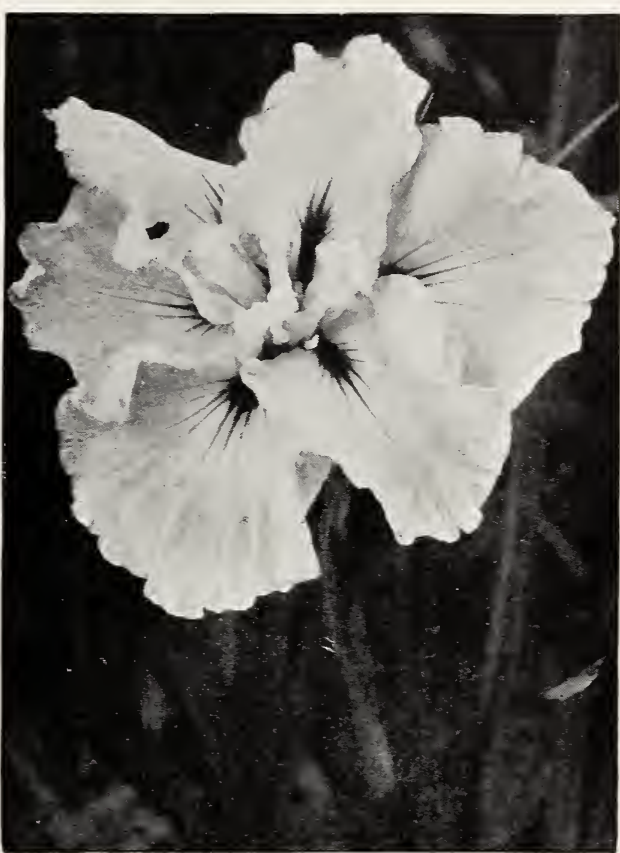

Japanese Iris. Iris kaempferi.

JAPANESE IRIS, continued

Mahogany. (Hallock, before 1893.) Dark red, shaded maroon; six petals; very distinct.

Maple Cascade. A choice double variegated variety; bright crimson-purple, beautifully feathered in white.

Melpomene. (Vilmorin, 1906.) Double; charming shades of lilac and blue.

Minerve. (Vilmorin, 1908.) Single; a lovely pink shade, tinted rose.

Moonlight Waves. (Gekka-no-nami.) White, overlaid light pink; yellow center. A very choice variety. $75 \mathrm{cts}$. each, \$7 for 10

Navy Blue. Rich dark blue, yellow at base; six petals.

Neptune. (Vilmorin, 1906.) Violet, overlaid dark blue; single.

Norma. (Hallock, 1893.) Double. Shining lavenderpink, tinged blue and gold at center. Large and fine.

Oscar. (Hallock, 1885.) Dark red, changing to a very light color.

Painted Lady. White, richly suffused and striped with bright pink; very showy.

Paragon. (Hallock, 1885.) Rich velvety purple; six petals.

Patrocle. (Vilmorin, 1907.) Single; superb dark reddish violet.

Proserpine Vilmorin. (Vilmorin, 1908.) Rich Iavender, stippled on grayish ground, center lavenderviolet edged white.

Purple and Gold. Enormous double flowers; early and free blooming. Color rich violet-purple with white petaloids.

Purple Emperor. (Wallace, 1910.) Very dark purple, yellow center; large flower and strong grower.

Pyramid. (Hallock, before 1893.) Lilac-blue veined with white in center of petals; six petals.

Reine des Bulgares. (Vilmorin, 1910.) Single; the three Iarge outer petals of soft lilac-blue finely veined with white, the lilac a little more pronounced in the small center petals, half yellow.

Turban. (Hallock, 1889.) Beautiful light blue and white; six petals. One of the best.

Uchi Wa. Cerulean-blue, yellow blotches surrounded with white halo radiating out into broad line; six petals; very long stems.

Venus. (HaIllock, before 1893.) Pure white. A strong grower and free bloomer. 
JAPANESE IRIS, continued

White Crane. (Manadzuru.) Six Iarge white petals blotched yellow and feathered blue. A very handsome and decorative variety.

William Tell. (Hallock, 1885.) White, veined with indigo; six petals. A very attractive variety. $50 \mathrm{cts}$. each, $\$ 4.50$ for 10 , $\$ 40$ per 100 .

Zama Forest. Large white blossom, the face of which is shaded with purple; three petals.

Kaempferi, Mixed Colors (Mixed Japanese Iris). 35 cts. each, $\$ 3$ for 10 , $\$ 20$ per 100 .

\section{Dwarf Bearded Iris}

Charming, very dwarf plants which bloom very early. The flowers are large and showy, of the same general appearance as the German Iris. They are very easily grown and spread rapidly into a dense mat, which makes them very suitable for edging borders and for rather broad patches in the rock garden. Coming into flower with the daffodils and tulips, they make a splendid prelude to the grand chorus of German and Japanese varieties which follow them.

*Bride. (Caparne, 1901.) A Iarge, showy, pure white. $\$ 1.05$ for $3, \$ 2.70$ for $10, \$ 20$ per 100 .

*Charmer. (Caparne, 1901.) A pretty little light blue flower, delightful in the rock garden. \$1.05 for 3, $\$ 2.70$ for 10 , \$20 per 100 .

*Cyanea. (Goos \& Koenemann, 1899.) Deep blue. $\$ 1.05$ for $3, \$ 2.70$ for $10, \$ 20$ per 100 .

*Excelsa. (Goos \& Koenemann, 1899.) 5 in. A fine yellow form. $\$ 1.05$ for 3, \$2.70 for $10, \$ 20$ per 100 .

* Pumila Atroviolacea. (Todaro, 1856.) A rich royal purple. $\$ 1.05$ for 3, \$2.70 for $10, \$ 20$ per 100 .

*Pumila Aurea. Bright yellow. $\$ 1.05$ for $3, \$ 2.70$ for $10, \$ 20$ per 100 .

*Sambo. (Perry, 1903.) 10 in. Dark purple with crimson veins. $\$ 1.05$ for $3, \$ 2.70$ for $10, \$ 20$ per 100

*Schneekuppe. (Goos \& Koenemann, 1910.) White, slightly veined darker at the base of petals. $\$ 1.50$ for $3, \$ 4$ for 10 .

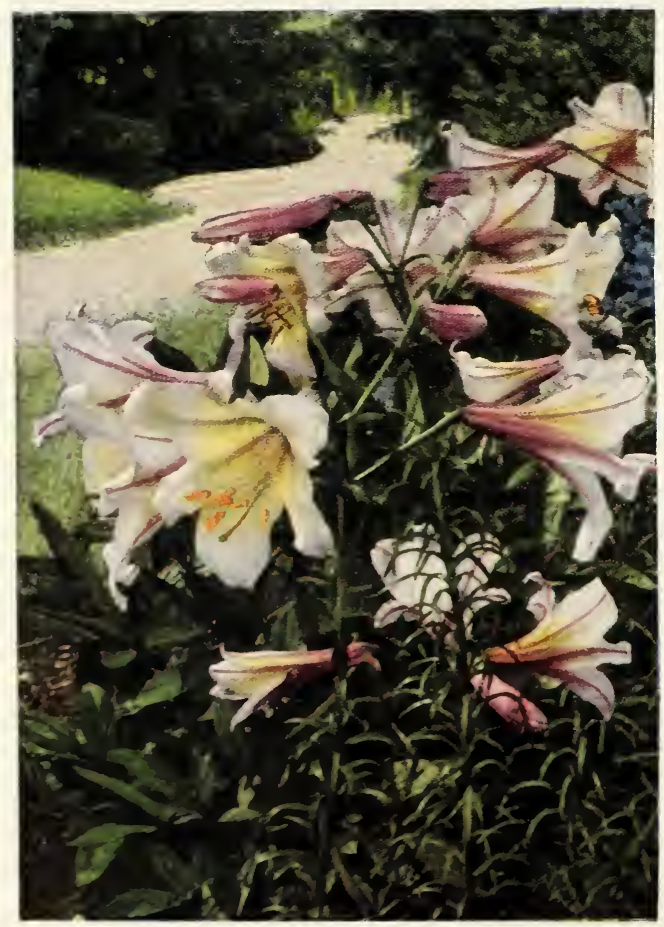

Lilium regale. Royal Lily. See page 76

\section{Miscellaneous Iris}

*Iris cristata. Crested Iris. 4 to 5 in. Early. A very Iow, southern species with charming light blue flowers marked with white. Pretty in open border and on a rock ledge. 90 cts. for $3, \$ 2.40$ for 10 , $\$ 18$ per 100.

I. chrysographes. Goldvein Iris. 2 to $3 \mathrm{ft}$. Rich, dark red-violet flowers of graceful form, conspicuously veined with golden yellow. A handsome late Iris, good for water-planting. $\$ 1.05$ for $3, \$ 2.70$ for 10 , $\$ 20$ per 100 .

1. pseudacorus. $4 \mathrm{ft}$. May and June. The common yellow Water-Flag, suitable for marshes and water-courses. 90 cts. for $3, \$ 2.40$ for $10, \$ 18$ per 100 .

I. sibirica. $3 \mathrm{ft}$. June. Long, narrow leaves; pale blue flowers. Fine for water-garden. 90 cts. for 3, $\$ 2.40$ for $10, \$ 18$ per 100 .

I. sibirica alba. A fine, pure white form. $75 \mathrm{cts}$. for $3, \$ 2.20$ for $10, \$ 15$ per 100 .

I. orientalis. A frne shade of Yale blue. $90 \mathrm{cts}$. for $3, \$ 2.20$ for $10, \$ 15$ per 100 .

1., Snow Queen. (Collected in Japan, 1900.) $3 \mathrm{ft}$. Large, weIl-formed and exquisite snowy white flowers in great abundance. Foliage very graceful. A gem for border or waterside. 90 cts. for $3, \$ 2.40$ for $10, \$ 18$ per 100 .

*I. verna. 4 in. A little Iow Iris with blue flowers, having a yellow center. 90 cts. for $3, \$ 2.40$ for 10 , $\$ 18$ per 100 .

1. versicolor. 20 in A native of stream-sides and swamps, producing its charming light purple flowers very freely in spring and early summer. 75 cts. for 3 , $\$ 2.20$ for $10, \$ 15$ per 100 .

\section{IBERIS}

Edging and rock plants of much refinement and beauty. They should be planted in broad clumps or long lines, and they like to be let alone when once established.

*Iberis gibraltarica. $1 \mathrm{ft}$. May and June. White flowers tinged rose. One of the most striking and showy sorts and not always obtained easily as the true stock is fairly rare.

*I. saxatilis corifolia. 6 in. May and June. The finest of the evergreen Candytufts, with dense clusters of pure white flowers.

*I. sempervirens. Evergreen Candytuft. $1 \mathrm{ft}$. May. Of loose, spreading habit and distinctive narrow evergreen foliage. Flowers pure white, completely covering the plant. Splendid for rock garden; good for edging borders.

*I. sempervirens, Little Gem. 6 in. May. A miniature form of the above which blooms profusely and makes a splendid little evergreen rock plant or edging.

*I. sempervirens, Snowflake. An early-flowering variety, with Iarge, snowy white flowers.

\section{INCARVILLEA}

Incarvillea delavayi. 18 in. June and July. A hardy, tuberous-rooted plant, and one of the choicest perennials yet introduced. The Iarge, rose-colored, trumpet-shaped flowers are produced in clusters and have unusual lasting qualities. Good border plants for sheltered positions. $\$ 1.20$ for $3, \$ 3$ for 10 .

\section{JASIONE}

*Jasione perennis. Sheep's-Bit. 6 to 12 in. July and August. A good rock or border plant of compact habit, bearing numerous round heads of blue flowers. 90 cts. for $3, \$ 2.40$ for $10, \$ 18$ per 100 .

\section{KNIPHOFIA - Torch Lily}

Kniphofia uvaria pfitzeriana. Bonfire Torcb Lilv. 2 to $3 \mathrm{ft}$. August to October. A Iily-like plant which produces extra-fine spikes of orange-scarlet flowers, with long, protruding anthers. 


\section{KNIPHOFIA, continued}

K. uvaria grandiflora. Day.glow Torcb Lily. 3 to $4 \mathrm{ft}$. The old-fashioned, Iate-flowering sort, with rich red flowers, changing to salmon.

K. uvaria nobilis. Giant Torcb Lilv. $4 \mathrm{ft}$. August to November. Immense spikes of orange-red flowers.

\section{LATHYRUS - Pea}

Lathyrus latifolius. Perennial Pea. $4 \mathrm{ft}$. July to September. Clusters of large, bright rosy red flowers, on long stems produced in abundance. Can be used as a tall, bushy perennial, or makes an excellent vine for covering rocks, stumps, and walls.

L. latifolius albus. Wbite Perennial Pea. $4 \mathrm{ft}$. July to September. A white-flowering variety of the above, useful for the same purposes. 90 cts. for 3 , \$2.40 for 10, S20 per 100 .

L. latifolius, Pink Pearl. $4 \mathrm{ft}$. July to September. An improved variety with clusters of large pink flowers. Fine.

*L. vernus. Spring Bittervetch. $1 \mathrm{ft}$. May and June. A compact, tufted little plant with blue-violet flowers. Does well in deep sandy loam either in sun or partial shade. 90 cts. for $3, \$ 2.40$ for 10 .

\section{LAVANDULA}

Lavandula officinalis (vera). True Lavender. $11 / 2 \mathrm{ft}$. July and August. This is the true Sweet Lavender. Delightfully fragrant blue flowers. \$1.05 for 3, $\$ 2.70$ for $10, \$ 20$ per 100 .

*L. officinalis nana. A dwarf, more compact plant than $L$. officinalis, with somewhat darker flowers, and blooms earlier. Good for rock garden. \$1.05 for $3, \$ 2.70$ for $10, \$ 20$ per 100 .

L. spica. Spike Lavender. $1 \mathrm{ft}$. July and August. A little lighter in color than the preceding, with shorter, denser spikes of flowers and even stronger and more pervasive scent. $\$ 1.05$ for $3, \$ 2.70$ for $10, \$ 20$ per 100 .

\section{LEONTOPODIUM • Edelweiss}

*Leontopodium alpinum. 6 to 8 inches. June to August. A famous alpine plant for a dry situation. The flowers are woolly, grayish white, and curiously shaped rosettes on the tops of sturdy stems. $\$ 1.20$ for $3, \$ 3.50$ for $10, \$ 30$ per 100 .

\section{LIATRIS}

Liatris pycnostachya. Cat-tail Garfeatber. 3 to $5 \mathrm{ft}$. August to October. A most striking and desirable plant, with great rocket-like spikes of pale purple flowers. Excellent for the border or among shrubbery.

L. spicata. Spike Gayfeatber. 2 to $3 \mathrm{ft}$. July to September. Slender spikes densely trowded with rosy purple flowers.

\section{LIGULARIA}

Ligularia clivorum. Ragweed. $4 \mathrm{ft}$. June to August. Spikes of yellow flowers and large, shiny green foliage. A bold plant for the waterside. 50 cts. each, $\$ 4$ for 10 , \$30 per 100.

L. veitchiana. $6 \mathrm{ft}$. Bright yellow flowers on tall stems forming spikes 2 feet long. A good border plant with large tufts of spreading foliage for shady places. 60 cts. each, $\$ 5$ for 10.

L. wilsoniana. Giant Groundsel. $4 \mathrm{ft}$. Rich golden yellow flowers and large, handsome foliage. 50 cts. each, $\$ 4$ for $10, \$ 30$ per 100 .

\section{LILIUM • Lily}

The Lilies are a marvelously beautiful and variable race and merit a great deal of attention in all perennial plantings. The white kinds are most highly finished and look best in more or less formal surroundings, while the red and orange kinds are more adapted to the edges of shrubbery or to neadow planting. Most Lilies require a little shade

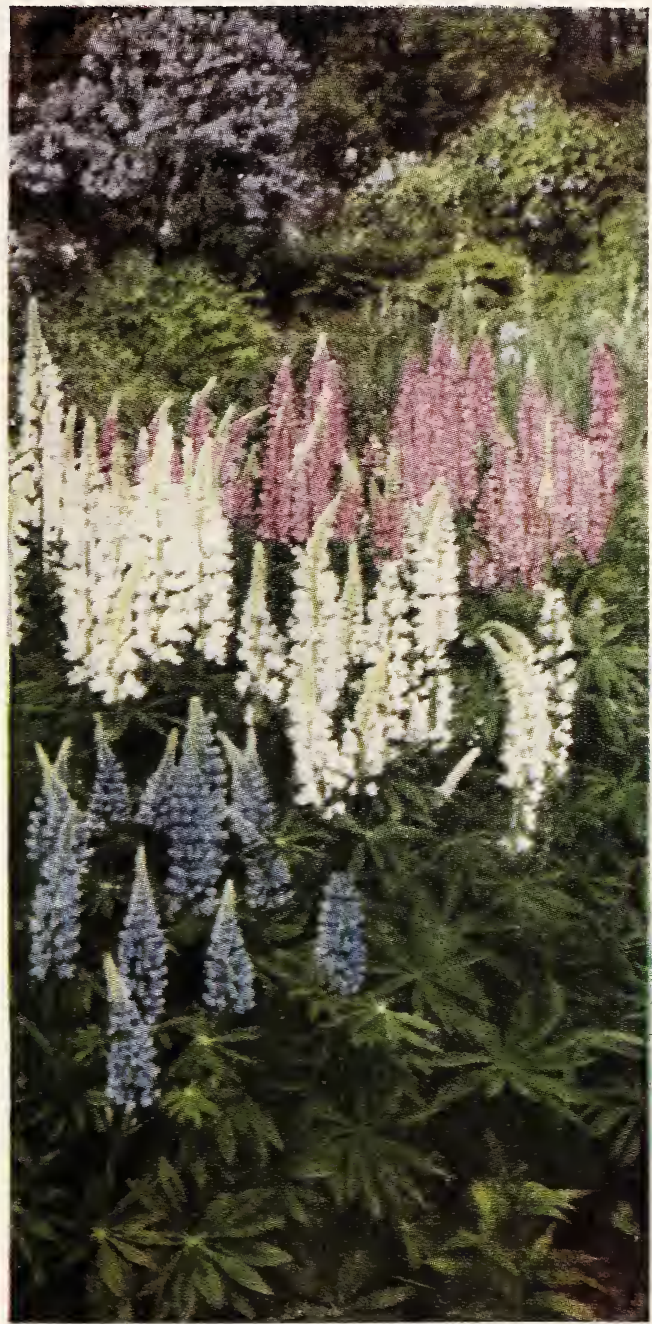

Washington, White Washington, and Blush Lupines. See page 76

LILIUM, continued

about their roots, and for that reason are best planted among low shrubs, or under thin trees. They like good soil, but no manure, and they must not be in wet ground.

Lilium auratum. Goldband Lily. $3 \mathrm{ft}$. July and August. Gigantic, pure white flowers with tiny crimson spots and a broad gold band through each petal. Especially effective scattered in rhododendron beds or massed in border. $\$ 1.50$ for $3, \$ 4$ for 10 , $\$ 30$ per 100.

L. canadense. Canada Lilv. 4 to $6 \mathrm{ft}$. July and August. Slender stems with whorled leaves and big, branching sprays of drooping, bell-like flowers varying from orange-yellow to tawny red.

L. candidum. Madonna Lilv. 2 to $3 \mathrm{ft}$. June and July. The most popular of garden Lilies. The pure white, very fragrant flowers are arranged like a snowy pyramid about the stiff, tapering stem. $\$ 1.20$ for $3, \$ 3.50$ for $10, \$ 30$ per 100 .

L. carolinianum. Carolina Lily. 2 to $4 \mathrm{ft}$. July and August. Same color as $L$. superbum, but with paler, almost white throat. $\$ 1.05$ for 3, \$3 for 10.

L. elegans. $11 / 2 \mathrm{ft}$. A dwarf sort, bearing clusters of erect flowers varying from orange to deep maroon. $\$ 1.05$ for $3, \$ 3$ for 10 . 
LILIUM, continued

L. Hansoni. Japanese Wax Lily. 3 to $4 \mathrm{ft}$. Stiff stems with whorls of narrow leaves, surmounted by sprays of nodding, reflexed flowers with thick, waxy petals of apricot-yellow dotted with brown. Grows well in ordinary garden soil, likes partial shade, and blooms in late spring. A very quaint and charming Lily, and one of the easiest to raise. $\$ 2.25$ for 3 , $\$ 6$ for 10 .

L. Henryi. Henry Lily. 6 to $8 \mathrm{ft}$. July and August. A very tall, sturdy Lily bearing giant sprays of reflexed, bright apricot-orange flowers somewhat like the Speciosums, each marked by a rich emeraldgreen crease at the base of each petal. Needs shade at the root and sun for the flowers. $75 \mathrm{cts}$. each, $\$ 6$ for 10 .

L. longiflorum giganteum. Giant Easter Lily. 4 to $5 \mathrm{ft}$. July and August. The white Lily sold by florists at Easter, and much more beautiful when grown in the garden where the golden anthers give it life and spirit. $\$ 1.80$ for $3, \$ 5$ for 10 .

L. regale. Roval Lily. 2 to $3 \mathrm{ft}$. This variety has enormous white flowers, shaded pink or purple, with a canary-yellow center. Undoubtedly the easiest of the white Lilies to grow and will grow almost anywhere, so long as the flowers can reach the sunlight. Lovely on top of a wall, or in the higher sections of the rock garden where it can be looked up to. $\$ 1.80$ for 3 , $\$ 5.50$ for $10, \$ 50$ per 100 .

L. speciosum album. White Speciosum Lily. $3 \mathrm{ft}$. August and September. Large, pure white, fragrant flowers. Fine for planting among rhododendrons. $\$ 1.50$ for $3, \$ 4.40$ for $10, \$ 40$ per 100 .

L. speciosum rubrum. Red Speciosum Lily. $3 \mathrm{ft}$. August and September. Large, fragrant flowers of light pink with a crimson stripe and many deep pink dots. Fine for planting among rhododendrons. $\$ 1.20$ for $3, \$ 3.50$ for $10, \$ 25$ per 100 .

L. superbum. American Turkscap Lily. 3 to $4 \mathrm{ft}$. July. Flowers bright reddish orange, conspicuously spotted. Especially effective scattered in margin of rhododendron beds. $\$ 1.05$ for $3, \$ 2.70$ for $10, \$ 20$ per 100.

L. tenuifolium. Coral Lily. 18 in. July. Slender, narrow-leaved plants with a few drooping smallish flowers of coral and vermilion. Very pretty and showy. \$1.05 for 3, \$3 for 10, \$25 per 100 .

L. tigrinum. Tiger Lily. 2 to $5 \mathrm{ft}$. August. Nodding, bright red flowers, thickly covered with large purplish spots in a pyramidal cluster. A thoroughly oldfashioned and remarkably useful plant. 90 cts. for 3 , $\$ 2.40$ for 10 , \$20 per 100 .

\section{LIMONIUM • Statice}

*Limonium latifolium. Bigleaf Sea Lavender. $2 \mathrm{ft}$. July and August. A most valuable plant either for the border or for the rockery. It bears tufts of leathery foliage and immense candelabra-like heads of minute, purplish blue flowers, the sprays often $11 / 2$ feet high and 2 feet across. If cut and dried, the flowers last in perfect condition for months.

\section{LINARIA}

*Linaria cymbalaria. Kenilwortb Ivy. A trailing plant or vine with ivy-like leaves and dainty little lavender flowers. A perfect plant for rock-crevices and for flaggings and walls. Also much used in hanging-baskets or wherever a vigorous, persistent trailing plant is desired.

\section{LINUM • Flax}

*Linum flavum. Colden Flax. $1 \mathrm{ft}$. June and July. A neat, bushy plant with numerous yellow flowers. Fine for rock garden. $\$ 1.05$ for $3, \$ 2.70$ for 10 .

*L. narbonnense. Narbonne Flax. 1 to $2 \mathrm{ft}$. May and June. A good, hardy plant of spreading habit, bearing large, azure-blue flowers in loose sprays. 90 cts. for $3, \$ 2.40$ for 10 .
LINUM, continued

*L. perenne. Perennial Flax. $11 / 2 \mathrm{ft}$. May to August. A desirable bushy little plant with wiry stems and a multitude of $[$ arge, clear blue flowers. Good in either border or rockery.

*L. perenne alba. White Perennial Flax. A whiteflowered variety of the above.

\section{LOBELIA}

Lobelia cardinalis. Cardinal Flower. $3 \mathrm{ft}$. July and August. A very showy variety with long spikes of scarlet flowers and handsome green foliage. Desirable for planting along water's edge.

L. siphilitica. Large Blue Lobelia. 2 to $3 \mathrm{ft}$. August and September. An interesting plant with dense spikes of showy deep blue flowers. Useful along edge of ponds or streams.

L. siphilitica alba. Large Wbite Lobelia. A handsome white variety. Good for damp ground or bogs. 90 cts. for $3, \$ 2.40$ for 10 .

\section{LUPINUS Lupine}

The Lupines are a coming flower. While they have long been grown to a limited extent, we are just beginning to realize the possibilities of these beautiful plants. They delight in dry, sunny situations and resent being disturbed when once established. A good, healthy border of them is rivalled in beauty only by the finest Delphiniums. One or two plants do not make much of a show; they should be planted by the dozen or the hundred.

Lupinus polyphyllus. Wasbington Lupine. 2 to $3 \mathrm{ft}$. June to September. Beautiful plants with handsome leaves and deep blue, pea-shaped flowers in bold, long spikes. Cut off faded flowers to insure continuous bloom.

L. polyphyllus albiflorus. White Wasbington Lupine. $3 \mathrm{ft}$. June to September. Fine, bold, showy plant with white flowers.

L. polyphyllus Moerheimi. Moerbeim Lupine. 2 to $3 \mathrm{ft}$. June to September. A new variety and one of the best Lupines. It produces fine long spikes of pink flowers in varying shades. Excellent for the border and cutting. $\$ 1.05$ for $3, \$ 2.70$ for $10, \$ 20$ per 100.

L. polyphyllus roseus. Blush Lupine. $3 \mathrm{ft}$. June to September. Very charming sort with rosy pink flowers. A free bloomer. $\$ 1.05$ for $3, \$ 2.70$ for 10 $\$ 20$ per 100 .

L. polyphyllus, Downer's Hybrids. This fine new strain embraces many shades of pink, white, and both light and dark blues and purples. $\$ 1.05$ for 3 , $\$ 2.70$ for $10, \$ 20$ per 100 .

\section{LYCHNIS • Campion}

A much-varied family of old-fashioned plants which have been grown under various namesViscaria, Lychnis, Agrostemma, etc. They are all permanent and pleasing and full of old-time charm. The individual plants are usually small and should be massed to secure showy effect. This is especially applicable to $L$. cbalcedonica and $L$. coronaria.

*Lychnis alpina. Arctic Campion. 4 in. An attractive alpine plant with tufted foliage and reddish purple flowers. $\$ 1.05$ for $3, \$ 2.70$ for $10, \$ 18$ per 100 .

L. chalcedonica. Maltese Cross. 2 to $3 \mathrm{ft}$. June to August. An old and valued plant with terminaI heads of very showy orange-scarlet flowers.

L. chalcedonica alba. 2 to $3 \mathrm{ft}$. A form of the preceding with white flowers.

L. coronaria. Rose Campion. $18 \mathrm{in}$. A woolly, branching plant with grayish leaves bearing brilliant carmine or crimson flowers. 75 cts. for $3, \$ 2.20$ for 10 , $\$ 15$ per 100 .

L. coronaria alba. White Campion. Same as preceding, except the flowers are white. They look well together. 75 cts. for $3, \$ 2.20$ for $10, \$ 15$ per 100 . 


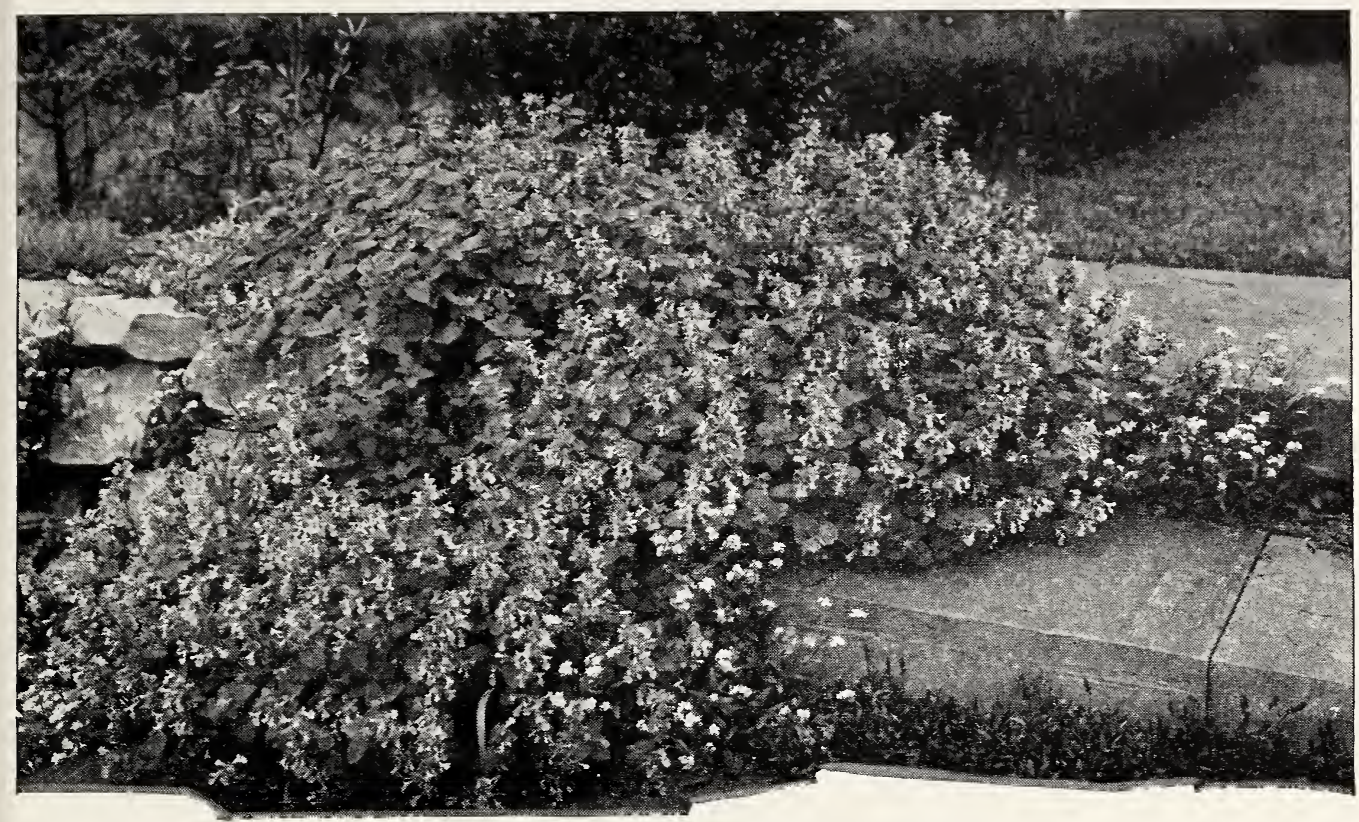

Nepeta mussini. A fine edging or rock plant. See page 78

\section{LYCHNIS, continued}

L. flos-cuculi. Ragged Robin. 12 to 18 in. June to September. A spreading plant with fringed pink flowers in clusters.

L. flos-jovis. Flower-of-Jove. 12 to 18 in. A fine oldfashioned plant making dense rosettes of leaves from which rise clusters of fringed rosy red flowers. L. haageana. Haage Campion. $1 \mathrm{ft}$. June to August. A very showy perennial, producing orange-red, scarlet, or crimson flowers nearly 2 inches across.

L. viscaria splendens flore-pleno. Double Rose-pink Campion. 12 to 15 in. June and July. A splendid variety of tufted habit with large, double, rose-colored flowers closely arranged on slender stems. A fine old-fashioned perennial adapted to the rock-garden or border, also good for cutting.

\section{LYSIMACHIA • Loosestrife}

Lysimachia clethroides. Cletbra Loosestrife. $2 \mathrm{ft}$. July. A pretty border perennial with long, dense spikes of starry white flowers and oval foliage with brilliant tints in autumn. Splendid for cut-flowers. 90 cts. for $3, \$ 2.40$ for $10, \$ 20$ per 100 .

*L. nummularia. Moneyuort. 4 in. June and July. A rapid-growing, creeping plant with round, shining leaves arranged in pairs, and small, yellow, bellshaped flowers. For hanging-baskets, rock-work, and walls, where it will make dense mats of foliage and flowers. $75 \mathrm{ctc}$. for $3, \$ 2.20$ for $10, \$ 15$ per 100

L. vulgaris. Golden Loosestrife. 2 to $3 \mathrm{ft}$. A vigorous, branching plant with pointed leaves in whorls, with large yellow flowers like golden stars on thread-like stems among the leaves, and packed into a leafy panicle at the top of the plant. Very showy and easy to grow. $\$ 1.50$ for $3, \$ 4$ for 10 .

\section{LYTHRUM}

Lythrum alatum. Winged Lytbrum. 2 to $3 \mathrm{ft}$. August to October. The very showy, deep purple flowers are borne in Iong spikes. Likes moist soil and is excellent among shrubbery.

L. salicaria roseum. Rose Loosestrife. 4 to $5 \mathrm{ft}$. July to September. A strong, erect plant with spikes of rosy flowers. Splendid for banks of streams.
LYTHRUM, continued

L. salicaria roseum, Perry's Variety. A choice new variety with glistening cherry-red flowers. A fine plant for naturalizing.

L. virgatum. Wand Lytbrum. 4 to $5 \mathrm{ft}$. July to September. A more slender plant than $L$. salicaria with smaller flowers, but of a deeper, more intense shade of rose-pink and purple. An excellent variety for landscape work because of its color value which shows up remarkably at a distance. $\$ 1.05$ for $3, \$ 3$ for 10 .

\section{MALVA - Mallow}

Malva alcea. Hollybock Mallow. $2 \mathrm{ft}$. Round, muchdivided leaves and numerous bright pink flowers; like small hollyhocks. Blooms all summer.

M. moschata. Musk Mallow. $11 / 2$ to $2 \mathrm{ft}$. July to September. Fragrant, rosy-tinted flowers in clusters. A very pretty and deserving plant which should be massed in borders.

M. moschata alba. White Musk Mallow. An exceptionally attractive variety with white, fragrant flowers.

\section{MAZUS}

*Mazus rugosus. 4 in. An interesting alpine plant from the Himalaya Mountains, covered in spring with dainty lilac and white flowers. $\$ 1.05$ for 3, $\$ 2.50$ for $10, \$ 20$ per 100

\section{MELISSA • Balm}

Melissa officinalis. Common Balm. 1 to $2 \mathrm{ft}$. June to August. An old-fashioned sweet herb, grown for its fragrant foliage. White and yellowish flowers in clusters.

\section{MENTHA • Mint}

Mentha piperita. Peppermint. A well-known useful herb with fragrant foliage. Thrives well in any soil. 75 cts. for $3, \$ 2.20$ for $10, \$ 15$ per 100 .

*M. requieni. Requien Mint. 2 to 4 in. This minute, creeping herb has tiny, round leaves and pale mauve flowers. Peppermint scented. $\$ 1.05$ for $3, \$ 3$ for 10 .

M. spicata. Spearmint. Purplish flowers on slender spikes. Foliage has an attractive taste and fragrance. 
MERTENSIA - Bluebells

*Mertensia virginica. Virginia Bluebells. 1 to $2 \mathrm{ft}$. Bears drooping clusters of beautiful blue and pink bell-like flowers in early spring. The foliage is large, light green, and disappears in midsummer. Prefers a moist, shady place.

\section{MISCANTHUS • Eulalia}

Miscanthus sinensis. Eulalia. 4 to $8 \mathrm{ft}$. A fine ornamental grass with ribbon-like leaves 2 to 3 feet Iong, making a big fountain-like clump from which its plumy flowers rise on stiff stems several feet above the leaves. Splendid for specimens and bordering paths or drives. $\$ 1.05$ for $3, \$ 3$ for $10, \$ 20$ per 100 .

M. sinensis variegatus. Striped Eulalia. Similar to $M$. sinensis but the leaves are striped lengthwise with yellowish white. $\$ 1.05$ for $3, \$ 3$ for $10, \$ 20$ per 100 . M. sinensis zebrinus. Zebra Grass. A variety with the leaves crossed with narrow yellowish white bands. Very handsome and effective. $\$ 1.05$ for 3 , $\$ 3$ for $10, \$ 20$ per 100

\section{MITCHELLA}

* Mitchella repens. Partridge Berry. A little trailing evergreen which forms firm mats in shady places and covers itself with sparkling crimson berries. It likes a very sour and a moist but well-drained situation.

\section{MONARDA}

Bold, showy, native plants which grow along streams and in fence-corners, and light up the dark corners of woods or thickets. They are much used in landscape work for broad, showy effects, and do sell at the back of ordinary borders, in full sun.

The flowers have a rich bergamot fragrance.

Monarda didyma. Oswego Beebalm. $11 / 2$ to $21 / 2 \mathrm{ft}$. June to September. Showy heads of brilliant scarlet flowers in rich profusion. Very effective.

M. didyma, Cambridge Scarlet. Beebalm. 2 to $3 \mathrm{ft}$. Heads of brilliant scarlet flowers. An improved variety.

M. didyma salmonea. Salmon Beebalm. A rather uncommon sort with flowers of soft salmon-pink. It likes a moist situation and is a beautiful massing plant. $\$ 1.05$ for $3, \$ 2.70$ for $10, \$ 20$ per 100 .

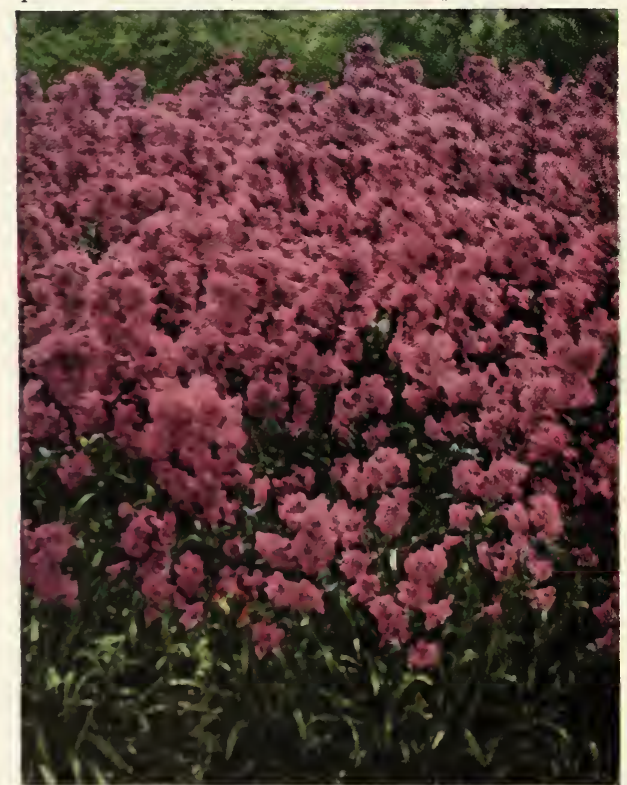

MONARDA, continued

M. didyma violacea superba. Amarantb Beebalm. A distinct sort with bright purple flowers.

M. fistulosa. Wild Bergamot. 2 to $3 \mathrm{ft}$. July and August. A pretty plant, producing fine lavender flowers. It will grow well in dry places.

M. fistulosa alba. White Wild Bergamot. $11 / 2$ to $2 \mathrm{ft}$. White flowers. Striking in masses along banks or in wild places.

\section{MYOSOTIS}

Finest of all edging plants for borders of springflowering bulbs, the Forget-me-nots are equally good for informal rock gardens or stonework of any kind; and the second variety is particularly adapted to the banks of streams or ponds. These are among the prettiest and showiest of flowers without being unduly gaudy, and they are especially fine with pale pink or creamy yellow flowers.

*Myosotis dissitiflora. Swiss Forget-me-not. 6 to 12 in. May to July. The deep sky-blue flowers are borne in small clusters. A good early-blooming variety for rock garden and edging bulb-beds. 75 cts. for $3, \$ 2.20$ for $10, \$ 15$ per 100 .

*M. scorpioides semperflorens. Perpetual Forgetme-not. 8 in. AII summer. Bright blue flowers in clusters, each one lit with a bright yellow eye. A very charming edging or rock-garden plant of more spreading habit then the preceding. Also fine for ponds and streams, growing weIl even in the water. 75 cts. for $3, \$ 2.20$ for $10, \$ 15$ per 100 .

\section{NEPETA}

Nepeta hederacea (glechoma). Ground Ivy. A Iow plant with pretty, round foliage and light blue flowers in early spring. As it creeps extensively, it is desirable for covering banks or under trees, spreading rapidly.

*N. mussini. An excellent plant for any position, but especially useful in the rock garden. It is compact, forming dense tufts about 12 inches high, with masses of small, light violet-blue flowers during July and August. $\$ 1.05$ for $3, \$ 2.70$ for $10, \$ 20$ per 100 .

\section{NIEREMBERGIA • Cupflower}

*Nierembergia rivularis. Wbitecup. Beautiful dwarf alpine plant with large, creamy white, cup-shaped flowers. A very adaptable and extraordinarily persistent plant for stream-banks, dry borders, or rock gardens. $\$ 1.05$ for $3, \$ 2.70$ for $10, \$ 20$ per 100 .

\section{EENOTHERA}

Enothera fruticosa major. Busb Snowdrops, $2 \mathrm{ft}$ June to September. A strong-growing plant, forming a dense bush-like specimen and bearing deep yellow flowers in profusion.

E. fruticosa youngi. Young's Sundrops, $2 \mathrm{ft}$. June to August. Strong, stocky, Iarge-leaved plant with firm. shiny foliage and numerous bright lemonyellow flowers.

*E. missouriensis. Ozark Sundrops. 10 in. June to August. Low-branched, almost prostrate plants, bearing a profusion of large, bright yellow, solitary flowers often 5 inches across. Good for rock garden or border. $\$ 1.20$ for $3, \$ 3$ for $10, \$ 25$ per 100 .

E. speciosa. 18 in. August and September. A fine, hardy plant with Iarge, pure white flowers. Spreads rapidly and is attractive in rock garden or naturalistic planting. $\$ 1.05$ for $3, \$ 2.70$ for $10, \$ 20$ per 100 .

\section{PACHYSANDRA. See Evergreen Shrubs}

\section{PARADISEA}

Paradisea liliastrum giganteum. St. Bruno's Lily. 1 to $2 \mathrm{ft}$. Similar to St. Bernard's Lily, Antbericum liliago, but has Iarger flowers and more of them. A charming lily-like flower. $\$ 1.05$ for $3, \$ 2.70$ for 10 , $\$ 20$ per 100 . 


\section{PAEONIA · Peony}

There is no question but that Peonies are one of the most important of the Hardy Perennials. The plants grow easily, are beautiful in foliage all season long, become larger and finer year by year, and are superbly beautiful when in flower, either for garden decoration or cutting. The numbers following the names of the varieties indicate the rating of their merit upon the basis of 10 as perfection. This rating was determined by a symposium among the members of the American Peony Society.

Albert Crousse. (Crousse, 1893.) 8.6 Large, ball-like flowers of magnificent form, and soft, creamy salmon-pink. One of the very finest. $75 \mathrm{cts}$. each, \$6 for 10 .

Augustin d'Hour. (Calot, 1867.) 7.8 Large, compact bomb-type flower of bright red. \$1 each, \$9 for 10.

Baroness Schroeder. (Kelway, 1889.) 9.0 Very large white flowers sometimes tinted pale pink, fragrant and floriferous. A strong-stem med variety particularly good for cutting. $\$ 1.50$ each, \$14 for 10.

Beaute Francaise. (Guérin, 1850.) 6.5 Pale Iilac-rose. Midseason. 75 cts. each, $\$ 6$ for 10

Comte de Nippon. Large; white with crimson spots. 75 cts. each, \$6 for 10.

Couronne d'Or. (Calot, 1873.) 8.1 Fine, very double flowers of creamy white with a strongly marked band of crimson-flecked petals and bright golden stamens about the center. A late and profuse bloomer. 75 cts. each, \$6 for 10.

Dorchester. (Richardson, 1870.) 7.7 Large, compact flower; pale hydrangea-pink; fragrant. Late. 90 cts. each, \$8 for 10.

Dr. Bretonneau. (Guérin, 1850.) 6.9 Large; pale lilac. Midseason. 75 cts. each, \$6 for 10 .

Duchesse de Nemours. (Calot, 1856.) 8.1 Beautifully cupped, pure white flowers of medium

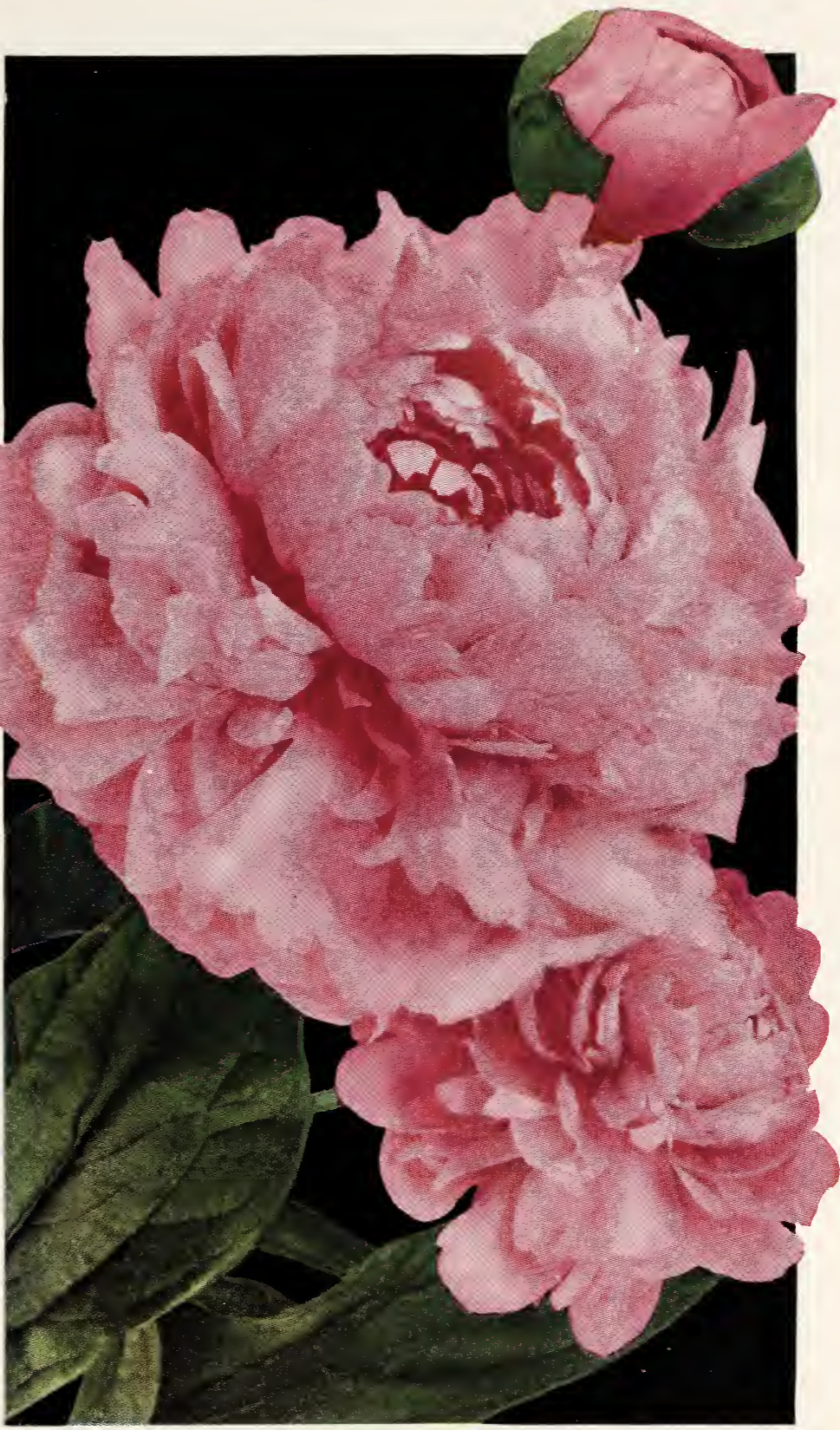
size, with lemon-yellow tints in the depths of its petals and a green base. Medium height; strong stems; early and productive. 90 cts. each, $\$ 8$ for $10, \$ 70$ per 100 .

Edulis Superba. (Lemon, 1824.) 7.6 Splendid, early flowers of rich rose-pink, with a fluffy, mounded or tufted center of lighter shades; fragrant. TaII, but stems bend, and very floriferous. An indispensable variety for its very cheerful, extremely early flowers, and widely popular. $75 \mathrm{cts}$. each, \$6 for 10.

Felix Crousse. (Crousse, 1881.) 8.4 Rich satiny crimson flowers with round, ball-like centers. Stems good; plant very floriferous. One of the very best crimson Peonies, and extremely effective in the garden. \$1 each, \$9 for 10.

Festiva Maxima. (Miellez, 1851.) 9.3 An old variety which carries a very high rating because of its superb, enormous, pure white flowers with occasional crimson flakes, its tall stems, and abundant blooming habit. Early. 75 cts. each, $\$ 6.50$ for $10, \$ 50$ per 100 .

Francois Ortegat. (Parmentier, 1850.) 6.7 Semidouble; I arge; purplish crimson with brilliant golden yellow anthers. $75 \mathrm{cts}$. each, $\$ 5$ for 10.

Golden Harvest. (Rosenfield, 1900.) 7.3 Medium size; pale Iilac-rose; fragrant. Dwarf. Midseason. 75 cts. each, $\$ 6$ for 10

Humei. (Anderson, 1810.) 5.7 Large, cherry-pink, tipped silver; fragrant. Very Iate. 75 cts. each, \$6 for 10. 
PEONIES, continued

Karl Rosenfield. (Rosenfield, 1908.) 8.8 Double, light crimson flowers of shapely form with distinctly waved and curling petals. Vigorous, floriferous plants with tall, strong stems. The finest red Peony at a moderate price, and by some regarded as the best of all. $\$ 1.50$ each, $\$ 14$ for 10 .

Kelway's Glorious. (Kelway, 1909.) 9.8 Immense, pure white flowers with long, deeply fluted petals arranged symmetrically about a lovely, rose-like center. Strong, delicious fragrance. Moderate height, good stems, and a free bloomer when established. One of the finest Peonies in the world and a general favorite for specimens in the Iandscape. \$12 each.

Lady Leonora Bramwell. (Kelway, ante 1895.) 6. Medium silvery pink. 75 cts. each, $\$ 6$ for 10.

Le Cygne. (Lemoine, 1907.) 9.9 A gigantic, ball-like bloom of purest cream-white, the broad, waxen petals incurved and overlapping like the feathers on the breast of a swan. The flower is the most nearly perfect of all Peonies and is correspondingly rated. Plant is not tall, rather compact, and blooms abundantly when once established. No Peony has been more eagerly desired and sought for and the stock is still scarce. \$10 each.

L'Indispensable. 7.3 Large to very Iarge fuIl rose type. Lilac-white, shading to pale violet at the center. \$1 each, \$9 for 10.

Louis Van Houtte. (Calot, 1867.) 6.9 Large, dark crimson-purple variety. None better. Late. 90 cts. each, $\$ 8$ for 10.

Marie Jacquin. (Verdier.) 8.3 A very beautiful cupshaped Peony of pale pink and lilac which opens pure white, with an elusive opalescence that defies description. The incurved petals cluster about its golden center in the most charming fashion and give warrant for its popular name, "The Water Lily Peony." \$1.25 each, \$11 for 10 .

Mary Brand. (Brand, 1907.) 8.7 Large, globeshaped blooms of light, showy crimson, a shade darker than Karl Rosenfield, which it resembles superficially, although it is somewhat Iarger and has other differences. One of the finest red Peonies in beauty of color, growth, and blooming quality. $\$ 2.50$ each, \$24 for 10 .

Mme. Auguste Dessert. (Dessert, 1899.) 8.6 Large flower of beautiful rose-pink, with outer petals and center slightly flecked with crimson. A very fine variety for landscape planting. Early midseason. \$2 each, \$18 for 10.

Mme. de Verneville. (Crousse, 1885.) 7.9 Very large and fragrant pure white with center tinged carmine. $90 \mathrm{cts}$. each, $\$ 8$ for 10 .

Mons. Jules Elie. (Crousse, 1888.) 9.2 An extra-fine early variety with a high mounded center clasped by an enveloping circle of wide, undulating guard petals, all shimmering, silvery pink. One of the finest and largest varieties for all purposes and should be in every garden. $\$ 1.25$ each, $\$ 11$ for 10 .

Officinalis Rosea. Pink. 75 cts. each, $\$ 7$ for 10 .

Officinalis Rubra. Brilliant, glowing, deep crimson. Early. This is the old-fashioned red Peony. \$1 each, \$9 for 10 .

Phoebe Cary. (Brand, 1907.) 8.8 An exquisite, globular flower of pale old-rose-pink with a delicate overcast of silvery lavender and Iilac. Its broad, imbricated petals give it a strongly individual character and charm. A very tall variety with long bending stems. Late-blooming. \$6.50 each.

Rosea Plena Superba. Delicate pink and salmon. $60 \mathrm{cts}$. each, $\$ 5$ for 10.

Rubra Superba. (Richardson, 1877.) 7.2 A beautifuI, rich, brilliant, dark crimson. Very late. $\$ 1$ each, S9 for 10.

Solfatare. (Calot, 1861.) 7.6 Milk-white, with a sulphur-yellow center. Midseason. 90 cts. each, $\$ 8$ for 10

Souvenir de Louis Bigot. (Dessert, 1913.) 9.1 A beautifully cupped, semi-double variety of soft rosepink shaded with shell-pink and illumined by numerous yellow stamens. One of the most exquisitely colored Peonies in existence, approaching Walter Faxon in this respect. Dwarf, free-blooming plants with strong stems. Midseason. S6 each.
Therese. (Dessert, 1904.) 9.8 Very large flowers with long, crisp petals of translucent old-rose-pink, spreading wide as it opens, disclosing a lovely rosebud center. Plant bushy, not tall, and very floriferous. This is one of the best loved Peonies and a prize-winner at all the shows. It carries a rating equal to Kelway's Glorious, and surpassed only by Le Cygne. It is impossible to do justice to its superb beauty here; it must be seen in your own garden to understand the enthusiasm with which all lovers of the Peony regard it. $\$ 3.50$ each, $\$ 33$ for 10 .

Tourangelle. (Dessert, 1910.) 9.4 A delicious variety with pale creamy flowers tinted with appleblossom-pink and pale champagne, deepening to shell-pink at the center. There is probably no Peony of greater delicacy of color and refinement of shape. It is not the most liberal bloomer in the world but is well worth having for its extreme grace and beauty. $\$ 3$ each.

Walter Faxon. (Richardson.) 9.3 Glowing pink of extraordinary brilliance, almost salmon-pink at times. Midseason. See picture in color, page 79 . $\$ 3.50$ each, $\$ 33$ for 10 .

Double Pink, Double Red, and Double White. 50 cts. each, $\$ 4$ for 10 .

\section{Single Peonies}

Camille. (Dessert, 1908.) 7.3 A splendid dark rose (nearly red), single Peony which blooms very late in the season. $\$ 1.50$ each, $\$ 13.50$ for 10 .

Carnot. (Dessert, 1913.) 7.7 A red, single Peony blooming earlier in the season then Camille. This variety has splendid stiff stems, and also a nice quantity of Iaterals. $\$ 2$ each, $\$ 18$ for 10 .

Le Jour. (Shaylor, 1915.) 8.6 Very large, single white flowers with a glorious golden center. We think it is the loveliest of all the single Peonies, from the first unfolding of its waxen buds to the wideflung beauty of its broad, undulating petals held firmly through all weathers. A magnificent variety for landscape use because of its strong stems, its floriferousness, and long blooming season. $\$ 2.50$ each, $\$ 22.50$ for 10 .

Lucienne. (Dessert, 1908.) 7.7 A dainty pink, single Peony whose lateraIs open almost as soon as the main bloom, but which, on account of being a little later, show a deeper pink color. This variety is taller than Nellie. $\$ 2$ each, $\$ 18$ for 10 .

Madeleine Gauthier. (Dessert, 1908.) 8.5 Exquisitely tinted silvery pink; single flowers of great size and charm. $\$ 2.50$ each, $\$ 22.50$ for 10 .

Marguerite Dessert. (Dessert, 1913.) 8.5 Very large, single bloom; pure white dotted carmine, with a crown of golden stamens. Very good. $\$ 4$ each, $\$ 35$ for 10 .

Mikado. (Japan, 1893.) 8.6 A gorgeous Japanese variety brought to the Chicago World's Fair in the Japanese exhibit in 1893. It has a flaring crimson cup surrounding a bronzy yellow tuft of staminodes compactly curled in the center. Extremely showy and brilliant in the landscape, and desirable for its vigorous growth, stiff stems, and great floriferousness. 2.50 each, $\$ 22.50$ for 10 .

Minerve. (Dessert, 1908.) 7.3 A pink, single Peony which is somewhat darker than the excellent variety Nellie, and the same height as that variety. $\$ 1.50$ each, 13.50 for 10 .

Mistral. (Dessert, 1905.) 7.3 This is a deep rose, single Peony, so deep, in fact, that the color approaches red or carmine. It has strong stems and good bloom on its laterals. \$1.50 each, \$13.50 for 10 .

Nellie. (Kelway.) 8.6 Clear, shell-pink, single flowers with a brilliant yellow center. A very beautifully shaped flower. $\$ 1.50$ each, $\$ 13.50$ for 10 .

Othello. (Dessert, 1908.) A deep rose, single Peony with a slightly brighter color-tone than Camille. It has good stems and good Iaterals. $\$ 1.50$ each, $\$ 13.50$ for 10.

Princess Mathilde. (Dessert, 1908.) $7.22 \frac{1}{2} \mathrm{ft}$. Large, single blossom, of white shaded Iavenderpink. $\$ 2.50$ each, $\$ 22.50$ for 10 . 
PEONIES, continued

The Moor. (Barr.) 7.8 Single, dark silky garnet flowers with a Iarge showy mass of golden stamens. A fine dark single. $\$ 1.50$ each, $\$ 13.50$ for 10 .

Vesuve. (Dessert, 1905.) 7.6 Very closely resembles Carnot. Intensely dark red, which contrasts well with golden stamens. \$2 each, \$18 for 10 .

\section{PAPAVER - Poppy}

*Papaver alpinum. 6 in. A pretty little alpin Poppy, with nodding, fragrant yellow flowers $\$ 1.05$ for $3, \$ 2.70$ for 10 .

$*$ P. alpinum album. $\$ 1.05$ for $3, \$ 2.70$ for 10 .

*P. alpinum roseum. The pink-flowered form $\$ 1.05$ for 3, \$2.70 for 10

*P. nudicaule. Iccland Poppy. $1 \mathrm{ft}$. These produce graceful orange, white, and yellow flowers all summer. Good for massing in border or rock garden.

P. orientale. Orientul Poppy. 2 to $3 \mathrm{ft}$. May to July. Glowing scarlet flowers of giant size with black blotch at base of each petal. A good plant for hardy or shrubbery borders. 90 cts. for $3, \$ 2.40$ for $10, \$ 18$ per 100 .

\section{Hybrid Oriental Poppies}

$50 \mathrm{cts}$. each, $\$ 4$ for $10, \$ 30$ per 100

The Hybrid Oriental Poppies are unrivaled in their barbaric splendor of color, ranging from silvery white, soft pink, and salmon to dark blood-crimson and black-maroon. They are very hardy and are one of the most permanent features of the garden. As they thrive in any good garden soil, they can be easily transplanted during their dormant season. In the spring we ship pot-grown plants only.

Beauty of Levermere. $4 \mathrm{ft}$. Enormous flowers of dark blood-red, sometimes a foot in diameter, with crimped petals and glittering black center

Cerise Beauty. Brilliant salmon-cerise with glittering black blotch at the base of each petal $2 \mathrm{I} / 2 \mathrm{ft}$.

Goliath. $31 / 2 \mathrm{ft}$. One of the most effective. Strong, erect stems, with enormous scarlet flowers in great abundance.

Loreley. Orange-scarlet.

Mrs. Perry. $3 \mathrm{ft}$. Beautiful shade of salmon-pink One of the finest.

Olympia. Semi-double flowers, extremely unusual in this family. They are brilliant scarlet overlaid with orange, giving them a blazing, iridescent sheen. Plants bushy and extremely free-flowering.

Orange Queen. Very large flowers of rich orange Free-flowering and extremely showy.

Oriental King. Strong stems of upright habit; large crimson-scarlet flowers.

Oriflamme. Immense, handsome flower of brilliant orange-scarlet.

Perry's White. Enormous flowers of pure satiny white with a striking crimson base. Extremely effective in masses.

Princess Victoria Louise. Soft salmon-pink flowers, shaded to blush-pink.

Queen Alexandra. BeautifuI clear rose-pink, with salmon shades.

Royal Scarlet. Rich glowing scarlet flowers of medium size, produced in greatest profusion. A strong grower.

\section{PENTSTEMON}

Attractive, showy plants for the hardy border allowing great range for choice in color and habit. The species are among the most permanent and hardy plants. They like fuIl sunshine, but the ground must not be too dry, or they are likely to disappear within a season or two.

Pentstemon acuminatus. Stiff Pentstemon. 15 to 18 in. July and August. An attractive and very satisfactory plant with stiff spikes of Iarge lilac flowers changing to purple.
PENTSTEMON, continued

P. arizonicus. 6 to 8 in. A low, somewhat sprawling variety with erect stems bearing slender tubular flowers of purplish blue. $\$ 1.20$ for $3, \$ 3.50$ for 10 , \$27 per 100.

*P. barbatus, Coral Gem. 21/2 ft. Dense, showy spikes of brilliant coral-red flowers. $\$ 1.05$ for $3, \$ 3$ for 10 .

*P. barbatus. Pink Beauty (formerly Huntington's Shell-Pink). 30 in. Clear, bright shelI-pink flowers on good spikes, not stringy like Torreyi. Perfectly hardy and makes a beautiful cut-flower and garden decoration. Very effective with gypsophila. $\$ 1.20$ for $3, \$ 3$ for $10, \$ 24$ per 100 .

P. diffusus. Busby Pentstemon. 1 to $2 \mathrm{ft}$. June and July. Showy spikes of light purple flowers.

P. heterophyllus. Violet Pentstemon. $2 \mathrm{ft}$. June and July. Flowers of a Iovely azure-blue.

P. lævigatus digitalis. Foxglove Pentstemon. $3 \mathrm{ft}$. June and July. Large spikes of Iong, pure white flowers, with purple-spotted throats. Excellent for planting in shrubbery border.

P. torreyi. Torrey's Pentstemon. $21 / 2$ to $31 / \mathrm{ft}$. July. One of the best varieties. Tall, loose spikes of scarlet flowers. Will bloom constantly if flowers are cut.

\section{PHALARIS}

Phalaris arundinacea variegata. Ribbon Grass; Gardener's Garters. 2 to $3 \mathrm{ft}$. An old-fashioned ornamental grass for bedding, specimens, or edging streams and ponds. The leaves are striped lengthwise with yellowish white.

\section{PHLOX}

About the most satisfactory of all perennials is the PhIox. It deserves a good place in the hardy garden or border. The best effects are obtained by planting masses of each color, not less than six, and even as many as two dozen or more of one kind together. They begin blooming in midsummer and continue until frost. In making selections keep in mind that while descriptions are often similar, the varieties have distinct characteristics and usually bloom at different periods. Our collection includes the finest sorts to be found in this country.

The PhInx family is very large and varies widely in habit and time of blooming. While the PanicuIata varieties are fine, showy border or massing plants, there are dwarf, early-flowering types which are splendid ground-covers, edging plants, and rock plants.

*Phlox amœna. Amæna Pblox. 4 to 5 in. April and May. Slender, erect plants, with clusters of bright pink flowers. A charming variety.

*P. divaricata. Wild Blue Pblox. $1 \mathrm{ft}$. May and June. The flat heads of Iarge, fragrant, Iilac-blue flowers are borne on slender, erect stems. One of the most delightful flowers of spring. Beautiful with pale yellow tulips. $\$ 1.20$ for $3, \$ 3$ for $10, \$ 20$ per 100 .

*P. divaricata alba. White form of Wild Blue Phlox.

*P. divaricata laphami. $1 \mathrm{ft}$. May and June. A new variety of $P$. divaricata, with darker blue flowers in wide-spreading heads. A splendid variation, blooming over a much longer period. $\$ 1.20$ for 3 , \$3 for 10 .

P. glaberrima suffruticosa, Indian Chief. $11 / 2$ to $2 \mathrm{ft}$. June. Clear purple-red flowers in large clusters, borne on erect stems.

P. glaberrima suffruticosa, Miss Lingard. 2 to $3 \mathrm{ft}$. June and July. A fine white variety with very faint Iilac eye and Iarge individual florets.

*P. ovata. Mountain Pblox. 1 to $11 / \mathrm{ft}$. Erect stems with small clusters of light red flowers about an inch across. A good rock plant.

P. paniculata. Garden Pblox. See page 83.

*P. stolonifera (reptans). Creeping Pllox. 6 to 12 in. A low, prostrate plant with tufts of light foliage, throwing up slender stems crowned with small clusters of purple and violet flowers. A rock plant. 75 cts. for $3, \$ 2.20$ for $10, \$ 15$ per 100 . 


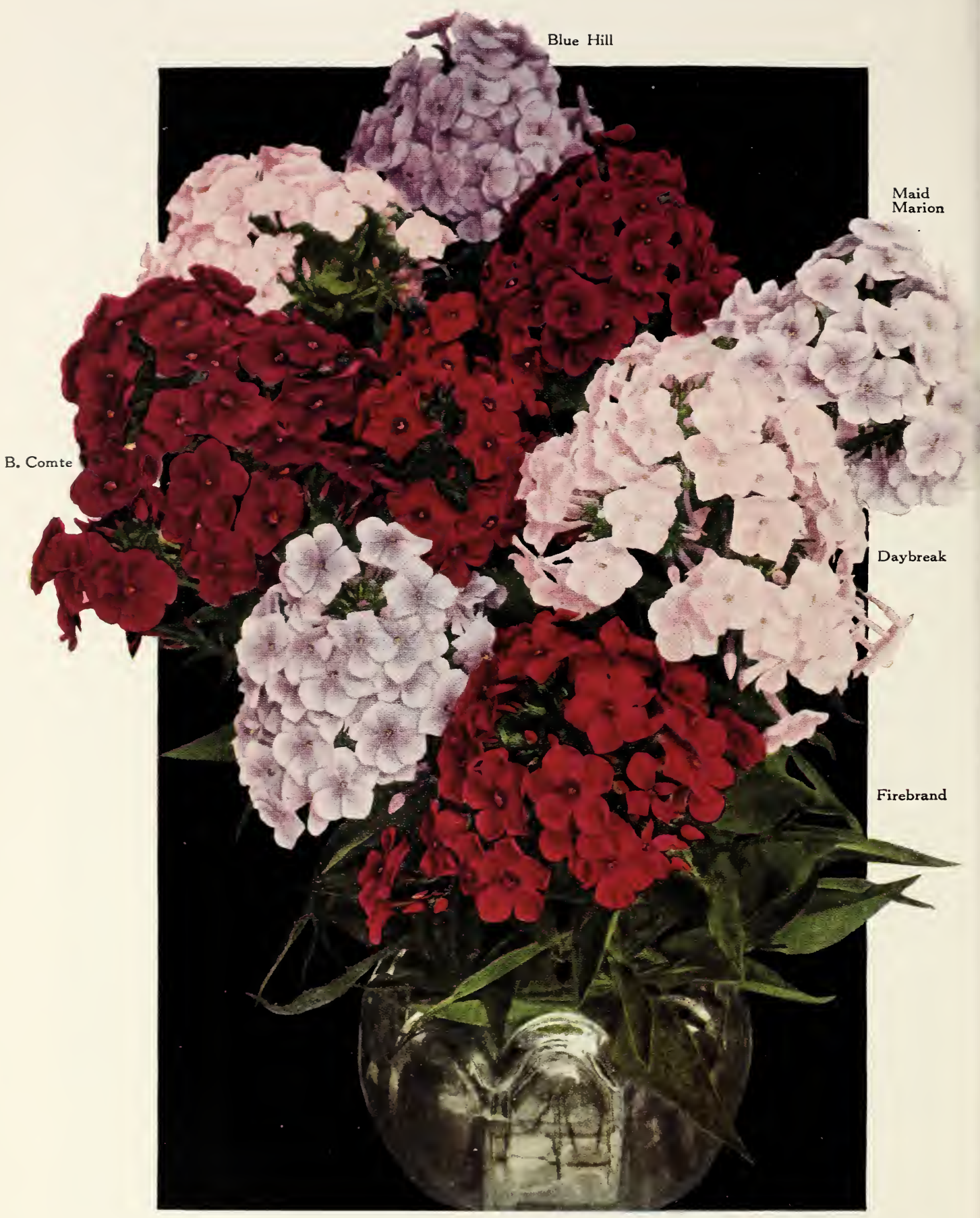

A great many varieties of Phloxes look too much alike in the mass, although they may differ widely in detail and habit. But here are five distinct kinds, illustrating almost the complete range of Phlox colors, each so different from the other that distinct masses of harmonizing or contrasting colors could be arranged. Plant them in good-sized clumps or broad sweeps of one or two kinds to get the best effect.

B. Comte. Crimson-purple.

Blue Hill. Light violet.

Maid Marion. Pale lilac.
Daybreak. Flesh-pink.

Firebrand. Scarlet. 
PHLOX, continued

*P. subulata. Moss Pink. 4 in. May and June. Forms a carpet of moss-like foliage, covered witl pink flowers. A superb ground-cover and rockery plant. 75 cts. for $3, \$ 2.20$ for $10, \$ 15$ per 100 .

Note.-We have two varieties of Pblox subulata, one light pink, and the other deep pink. Specify which you prefer.

*P. subulata alba. White Moss Pink. A form of $P$. subulata, equally valuable in all respects, with charming white flowers. $75 \mathrm{c}$. for $3, \$ 2.20$ for $10, \$ 18$ per 100

*P. subulata, G. F. Wilson. Blue Moss Pink. Lilacblue flowers with a lighter center. 75 cts. for 3 , $\$ 2.20$ for $10, \$ 15$ per 100 .

*P. subulata lilacina. Soft light lilac flowers and rapid growth. A charming companion for early, pale yellow flowers. 75 cts. for $3, \$ 2.20$ for 10 , $\$ 15$ per 100.

*P. subulata nelsoni. White flowers occasionally very faintly tinged at the eye. Growth is compact and moss-like. $75 \mathrm{cts}$. for $3, \$ 2.20$ for $10, \$ 15$ per 100

*P. subulata, The Bride. White, with red center. *P. subulata, Vivid. The clearest bright pink color in the creeping Phloxes. Makes a very bright and pretty showing free from the magenta tones which many object to. A compact grower; very fine. $\$ 1.50$ for $3, \$ 4$ for $10, \$ 36$ per 100 .

\section{Paniculata or Garden Phlox}

This is the group of very showy, midsummerblooming Phlox whose bewildering variety of color is so extremely interesting and beautiful. They are of easiest culture, but care should be taken not to let them seed as the seedlings are inferior and tend to crowd out the original plants, thus giving rise to the notion that they run out or change color.

We are continually adding new varieties to our collection and will have a number of new things in bloom in our frelds this summer. We shall be delighted to show them to interested visitors.

All varieties of Phlox paniculata, except as noted, $90 \mathrm{cts}$. for 3 of a kind, $\$ 2.40$ for $10, \$ 18$ per 100

Albion. Medium height; white flowers with pale pink edge. 75 cts. for $3, \$ 2.20$ for $10, \$ 15$ per 100 .

Annie Cook. Flesh-pink.

Atlas. Salmon-pink. A very tall grower.

B. Comte. Very dark, velvety red. The most effective dark variety. Very late.

Baron von Dedem. Salmon-red; very effective.

Beacon. Brilliant cherry-red.

Blue Hill. This Phlox is the nearest to a blue of any we have seen. $\$ 1.05$ for $3, \$ 3$ for $10, \$ 24$ per 100 .

Boule de Feu. Cherry-red. Late.

Bridesmaid. White, light pink center.

Camillo Schneider. A very Iarge-flowering variety of brilliant crimson, brighter than B. Comte and does not fade in the garden. The plant is stout, of medium height and bears magnificent trusses of bloom. Remarkable for its vigor, brilliance, and floriferousness, and regarded as the best of this color. $\$ 1.50$ for 3 , $\$ 4$ for $10, \$ 24$ per 100 .

Commander-in-Chief. New. Beautiful crimsonred with darker eye; color does not bleach or fade. $\$ 1.05$ for $3, \$ 3$ for $10, \$ 24$ per 100 .

Coquelicot. Orange-scarlet. One of the most showy. $\$ 1.05$ for 3, \$3 for 10, \$24 per 100

Count Zeppelin. Very large, clean, white flowers with sharply contrasting scarlet eyes. Brightest and best Europa type. $\$ 1.50$ for $3, \$ 4$ for $10, \$ 24$ per 100

Daybreak. A very scarce sort of exquisite refinement of color, dainty apple-blossom-pink, softer and more delicately tinted than the popular Mme. Paul Dutrie. This is one of the very choicest colors and a variety badly needed in gardens to supply the grace and lightness so lacking in midsummer color effects. $\$ 1.50$ for $3, \$ 4$ for $10, \$ 30$ per 100 .

Debs. The finest red Phlox there is. Color is bright frery crimson. There is no other Phlox that resembles Debs. $\$ 1.20$ for $3, \$ 3.50$ for $10, \$ 30$ per 100 .

Eclaireur. Large carmine flower with lighter center.

\section{PHLOX PANICULATA, continued}

Elizabeth Campbell. Bright salmon-pink, dark red eye. One of the really famous varieties. $\$ 1.05$ for 3 , \$3 for $10, \$ 24$ per 100 .

Enchantress. Very bright salmon-pink. Large trusses. Similar to Elizabeth Campbell, but a little brighter and a stronger grower. $\$ 1.05$ for $3, \$ 3$ for 10 $\$ 24$ per 100

Ethel Pritchard. Handsome, stately heads of soft mauve and lilac. A charming sort. \$1.05 for 3 , $\$ 3$ for $10, \$ 24$ per 100 .

Etta's Choice. A late, very tall, free-flowering white.

Europa. Flowers large, white with a decided crimson eye; trusses large.

Firebrand. Bright red with deeper center. $\$ 1.05$ for 3 , $\$ 3$ for $10, \$ 24$ per 100.

Frau Anton Buchner. Very large, pure white flowers.

Frau G. von Lassburg. Pure white flowers in enormous panicles. Late.

General van Heutz. Orange-scarlet with white eye.

Goliath. An excellent red sort with darker eye. TalI; Iarge trusses.

Hans Volmuller. Large, white flowers marbled with pale violet and suffused with mauve. A very delicate color. $\$ 1.50$ for $3, \$ 4$ for 10.

Independence. See Mrs. Jenkins.

Iris. $4 \mathrm{ft}$. Light purple-blue.

Jeanne d'Arc. Tall; pure white; Iate flowering.

Johnson's Favorite. Light salmon-pink with a dark red eye, resembling Elizabeth Campbell. but a strong grower. $\$ 1.50$ for $3, \$ 4.50$ for $10, \$ 39$ per 100

Jules Sandeau. A Iarge, fine, very free-flowering, pure pink variety that grows about 15 inches high. $\$ 1.05$ for $3, \$ 3$ for $10, \$ 24$ per 100 .

Juliet. Light pink, dark red eye.

Julius Heurlin. Light salmon-pink.

L'Esperance. Light lavender-pink, Iarge white center.

L'Eveneinent. Delicate pink, tinted salmon; dwarf.

Le Mahdi. Large heads of deep velvety purple blooms.

Maid Marian. Soft lavender, very even in color. $\$ 1.05$ for $3, \$ 3$ for $10, \$ 24$ per 100 .

Mia Ruys. 12 in. A good improvement over Tapis Blanc. Pure white blooms in big trusses. $\$ 1.20$ for 3 , $\$ 3.50$ for $10, \$ 30$ per 100 .

Michaei Buchner. Dark purple.

Mme. Paul Dutrie. Soft pink, suffused with white.

Mme. Prosper Laugier. Bright red, vermilion center.

Mrs. Jenkins. Independence. Pure white; very large truss.

Mrs. Milly van Hoboken. Bright pink with soft mauve suffusion. A splendid Phlox and unquestionably one of the finest of the newer varieties. $\$ 1.05$ for 3, $\$ 2.70$ for $10, \$ 20$ per 100 .

Mrs. P. Pfitzer. A splendid, newly imported variety of a very clear shade of light mauve-pink. It is of dwarf, sturdy habit and a splendid addition to the fine newer Phloxes. $\$ 1.50$ or $3, \$ 4$ for 10.

Mrs. Rutgers. Enormous, broad trusses of extralarge flowers tinted with light rosy lilac. $\$ 1.20$ for 3 , $\$ 3.50$ for 10.

Mrs. Scholten. Rich, dark salmon-rose of impressive size and finish. Very handsome. $\$ 1.50$ for $3, \$ 4$ for 10

Pantheon. Brilliant rose with lighter center.

Peachblow. Delicate pink, rose center; beautifu trusses. Rather dwarf.

Pecheur d'Island. A splendid tall variety with bricht purple blooms.

Professor Virchow. Brilliant carmine, overlaid with orange-scarlet.

Rheinlander. This new variety has immense blossoms of salmon-pink, with claret eye. $\$ 1.05$ for 3 , \$3 for $10, \$ 24$ per 100 .

Richard Wallace. Pure white, violet-rose center.

Rijnstroom. Bright carmine-rose.

R. P. Struthers. Bright, pinkish salmon; crimson eye.

Special French. Mammoth trusses of fine, even form. Florets very large, soft rose-pink with bright eye. Somewhat like Mrs. Milly van Hoboken, but not quite so tall.

Tapis Blanc. A beautiful pure white variety with large flowers. A very dwarf grower. $\$ 1.05$ for 3 , $\$ 2.70$ for $10, \$ 20$ per 100 . 


\section{PHLOX PANICULATA, continued}

Thor. Lively shade of deep salmon-pink, suffused and overlaid with a scarlet glow; aniline-red eye.

Victor. Large, bright salmon-pink bloom. \$1.05 for 3, $\$ 2.70$ for $10, \$ 20$ per 100 .

W. C. Egan. Very large flowers of delicate lilac, with Iarge, bright solferino eye. The color effect as a whole is a pleasing shade of soft pink.

Widar. Light reddish violet with large white center.

\section{PHYSALIS • Ground Cherry}

Physalis francheti. Cbinese Lantern Plant. 1 to $2 \mathrm{ft}$. Large heart-shaped leaves, with small whitish flowers, followed in the autumn with large, bright coral-red fruit, enclosed in a brilliant orange-red balloon-shaped bag of papery texture. Fine for decoration in winter.

\section{PHYSOSTEGIA • False Dragonhead}

These native plants revel in damp lowlands along streams or in cool fence-corners. They are splendid for naturalizing, and make good border plants, quickly forming broad, permanent clumps. In borders where rare things are growing that are likely to be crowded out by them, it is wise to dig them up every spring and reset them. There will always be plenty of roots left over to use in some other part of the garden.

Physostegia virginiana alba. 2 to $3 \mathrm{ft}$. White False Dragonbead. July to September. Erect plants with small slender spikes of beautiful white flowers of curious form.

P. virginiana rubra. $3 \mathrm{ft}$. Red False Dragonbead. A similar variety with dark pink or rosy red flowers. P. virginiana speciosa. Tall Cluster False Dragonbead. $3 \mathrm{ft}$. August. A tall and very useful form, with showy dark pink flowers.

P. virginiana grandiflora, Vivid. A wonderful little plant, growing about 15 inches high, with unusually large flowers of glowing mauve-pink. 90 cts. for 3, $\$ 2.40$ for 10 .

\section{PLAT YCODON • Balloon Flower}

As soon as the bells of Campanula medium have faded, the Platycodons open their handsome, saucer-like flowers and take up the burden of carrying on the beauty of the Bellflower race. Their stems are wiry and very slender and the plants take a season or two to become thoroughly established, so they should not be disturbed when they are growing well. Use them in masses or borders in the same manner as Canterbury Bells.

Platycodon grandiflorum. Balloon Flower. 18 in. June to October. Large, showy, deep blue flowers. P. grandiflorum album. White Balloon Flower. White-flowered form of the above.

P. grandiflorum mariesi. Maries' Balloon Flower. 12 to 15 in. July until late September. A beautiful dwarf species with broad, thick foliage and large, deep violet-blue flowers.

\section{PLUMBAGO. See Ceratostigma.}

\section{PODOPHYLLUM}

Podophyllum peltatum. Common Mav-apple. $1 \mathrm{ft}$ An erect herb with creeping rootstalks and fibrous roots. The large leaves are usually borne in pairs and look like an umbrella, bearing an exquisite white flower at the point where their stems divide.

\section{POLEMONIUM}

*Polemonium cæruleum. Greek Valcrian. 11/2 to $2 \mathrm{ft}$. June to September. Long, fern-like foliage with the shoots surmounted by terminal clusters of bell-like blue flowers.

*P. cæruleum album. Wbite Greek Valerian. A handsome pure white-flowered form of the above.

\section{POLEMONIUM, continued}

*P. reptans. Jacob's Ladder. 8 to $10 \mathrm{in.} \mathrm{April} \mathrm{to}$ June. Dwarf, bushy plant of graceful growth, with showy blue, bell-like flowers. Fine rock-garden and border plant. Not a creeping plant as its specific name would indicate.

F. richardsoni. Dwarf Polemonium. 15 to 18 in. June to August. Very bushy plant with persistent foliage, handsome all season long, and fine curved clusters of ruffled, blue, bell-like flowers.

\section{POL YGONATUM}

Polygonatum commutatum (giganteum). Great Solomon's Seal. 2 to $3 \mathrm{ft}$. Long, arching stems, with pairs of lily-like leaves from the joints of which the tiny whitish flowers hang down like little bells. Fine for growing in shade.

\section{POL YGONUM • Fleece Flower}

Polygonum affine. Himalayan Fleece Flower. 12 to 18 in. August and September. An excellent little plant for cool places, with bright rosy red flowers in dense spikes at the tips of the stems.

P. cuspidatum (sieboldi). Japanese Fleece Flower. 4 to $8 \mathrm{ft}$. August and September. A very effective plant for mass effects, with tall, gracefully arching stems covered with a cloud of small whitish flowers in great drooping sprays. $\$ 1.05$ for $3, \$ 2.70$ for 10 , $\$ 20$ per 100.

P. filiforme variegatum. Marbled Jumpseed. 18 in A long-lasting plant with leaves marbled yellow and pale green; slender spikes of whitish flowers.

\section{POTENTILLA • Cinquefoil}

Few flowers are more persistent and easily grown than these graceful little relatives of the roses. The leaves and flowers resemble those of the strawberry, and they are particularly pretty and attractive in the rockery during July, when their bloom is most profuse.

*Potentilla atrosanguinea. Himalayan Cinquefoil. 18 in. June to August. A bushy, leafy plant with rich crimson, single flowers.

*P. fragiliformis. 6 to 9 in. June. A choice little plant with leaves like a strawberry and large yellow flowers. $\$ 1.20$ for $3, \$ 3.50$ for $10, \$ 25$ per 100 .

*P. grandiflora. Alpine Cinquefoil. 10 to 20 in. June and July. These good border plants have an abundance of bright yellow flowers and are also very desirable for the rock garden.

*P. hippiana. 6 in. Silvery foliage and rather small yellow flowers. $\$ 1.20$ for $3, \$ 3.50$ for $10, \$ 25$ per 100

*P. hirta. A scarce, but easily grown variety for naturalizing on dry banks or stony places. $\$ 1.20$ for $3, \$ 3.50$ for $10, \$ 25$ per 100 .

*P. hybrida, Miss Willmott. 9 in. A prostrate plant with masses of foliage and an abundance of bright cerise flowers. $\$ 1.05$ for $3, \$ 2.70$ for $10, \$ 20$ per 100 .

P. nepalensis (formosa). Nepal Cinquefoil. 1 to $2 \mathrm{ft}$. July and August. Bushy plant of neat habit with purple-red flowers. The stems grow long and zigzag during midsummer.

*P. purpurea flore-pleno. A handsome little plant bearing pretty, double, rich purple flowers in great profusion.

*P. pyrenaica. Pyrenees Cinquefoil. 10 to 15 in July and August. This very useful little rock plant is closely related to and resembles the Alpine Cinquefoil, with fine yellow flowers an inch or more broad.

*P. tridentata. Wineleaf Cinquefoil. $1 \mathrm{ft}$. June to August. A splendid plant for dry banks and rockeries, with small clusters of white flowers.

\section{PRIMULA - Primrose}

Primroses, Cowslips, and Oxlips are among the plants of song and story. They are none too com- 


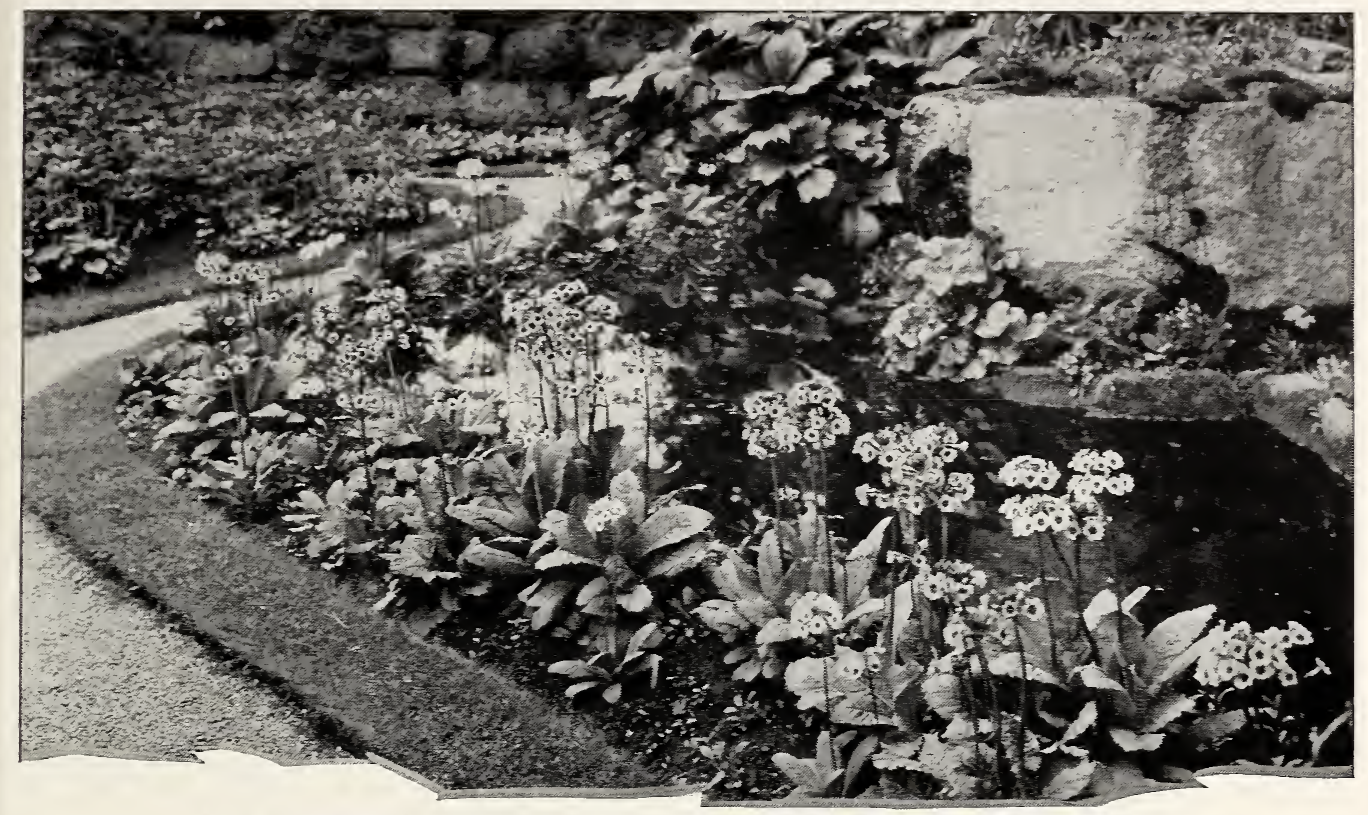

Primula japonica. In moist shady places the Japanese Primrose thrives in a beautiful fashion

PRIMULA, continued

mon in American gardens, chiefly because they do not like hot, dry situations and need the moist, deep ground along a stream-bank or the deep shade of deciduous trees or shrubs. Given the locations they like, and a few leaves scattered over them in autumn, even the fine hybrid strains thrive in a wonderful fashion. Mixed with forget-me-nots, they make a very attractive carpet under the edge of shrubs or along a shady border, but they should always be massed in quantity and fairly close together. Besides the common and fancy varieties of Primroses, we have a few of the more unusual species and varieties of this almost endless family. To grow all the Primroses would be a fascinating and absorbing pastime, but there is scarcely land enough in New England to do it.

* Primula acaulis (vulgaris). Englisb Primrose. 6 to 8 in. May and June. The true English Primrose is a delightful, much-prized pIant, forming tufted rosettes of leaves among which the charming light yellow flowers nestle on the tip of slender stems. A beautiful little rock-garden plant or edging for an informal path, and makes a delightful combination with myosotis. $\$ 1.05$ for $3, \$ 2.70$ for $10, \$ 20$ per 100 . *P. a uricula alpina. Alpine Auricula. 6 to 8 in. Attractive rosettes of thick leaves often covered with a mealy down. The flowers are large and round, borne in a cluster on the top of short, erect stems, and come in many shades. They are very fragrant. A very charming plant for the rock garden. May and June.

*P. Beesiana. $2 \mathrm{ft}$. Spikes of rich, velvety purple flowers with showy yellow eyes. Unusual and very choice. $\$ 1.05$ for $3, \$ 2.70$ for $10, \$ 20$ per 100 .

P. bulleyana. $1 \frac{1}{2}$ to $2 \frac{1}{2} \mathrm{ft}$. Late spring and summer. Long, thin leaves, widest at the ends, with a tall stem bearing several clusters of orange-vellow flowers above each other. A good plant for a halfshady border or among large rocks in the rock garden. $\$ 1.05$ for $3, \$ 2.70$ for $10, \$ 20$ per 100 .

*P. denticulata cachemiriana. Kasbmir Primrose. Clusters of leaves which are heavily dusted with meal on the under side. The flowers are Iarge, purple-blue with a golden eye, clustered on an erect stem. Rare and handsome.
PRIMULA, continued

*P. elatior alba. Oxlip. 8 to 12 in. May and June. Taller and stronger than the Primroses and Cowslips, with big clusters of erect white flowers. A fine plant of many old associations. $\$ 1.05$ for $3, \$ 2.70$ for $10, \$ 20$ per 100 .

*P. japonica. Japanese Primrose. 1 to $2 \mathrm{ft}$. Early to midsummer. Strong, handsome plants for rich soil in shady places, producing fine clusters of flowers of light pink and cream shades on the top of slender but strong, erect stems. A highly desirable plant.

*P., Moerheim's Hybrids. A handsome strain of the $P$. japonica type with flowers of all colors and shades-yellow, purple, crimson, orange, cream, gold. They like a moist, half-shaded Iocation. $\$ 1.05$ for $3, \$ 2.70$ for 10 , $\$ 20$ per 100 .

*P. polyantha, Munstead Strain. 6 to 12 in. May and June. A splendid strain of the popular Polyanthus, comprising flowers of many charming shades of yellow from cream to dark orange. This strain was perfected by Miss JekyII in England.

P. pulverulenta. Silverdust Primrose. $11 / 2$ to $3 \mathrm{ft}$. Early to midsummer. A fine plant for massing in deep, rich soil, and is particularly fine along banks of streams. Much like P. japonica but taller, with a silvery stem and darker, almost violet, flowers. $\$ 1.0 \overline{5}$ for $3, \$ 2.70$ for 10 , $\$ 20$ per 100 .

*P. veris hybrida (officinalis). Drooping Couslip. 6 in. April and May. The clustered, drooping flowers range in color from crimson to deep yellow and pure white.

P. vulgaris. See $P$. acaulis.

\section{PYRETHRUM}

See Chrysanthemum coccineum

\section{PRUNELLA • Self-Heal}

*Prunella grandiflora. Great Self-Heal. 9 to $10 \mathrm{in}$. June and July. A pretty little border or rock plant with Iarge heads of dark violet-blue flowers of curious shape.

*P. webbiana. Webb's Self-Heal. $1 \mathrm{ft}$. Round heads of showy purple flowers throughout the summer. 


\section{PULMONARIA · Lungwort}

*Pulmonaria saccharata. Betblebem Lungwort. 9 to 15 in. Mertensia-like flowers that last alI summer. Pretty foliage. A shade-loving plant. \$1.20 for 3, $\$ 3.50$ for $10, \$ 27$ per 100 .

\section{RANUNCULUS • Buttercup}

Ranunculus acris flore-pleno. Tall Double Buttercup. $2 \mathrm{ft}$. May to September. Flowers deep glossy golden yellow and very double. Leaves coarsely toothed or cut. This is one of the many plants referred to as Bachelor's Buttons.

R. repens. Creeping Buttercup. 8 in. May to July. A coarse-leaved plant having flowers of glossy yellow and prostrate branches often 2 feet long.

\section{RUDBECKIA - Coneflower}

These very showy plants are found in most gardens in one or more of their many forms. They are easy to grow, very persistent, and the singleflowered varieties fit splendidly into any naturalistic planting. Rudbeckia triloba is especially fine in Iate autumn at the edge of shrubberies and mixed with the late blue aconitums, while $R$. speciosa and the lighter yellow varieties are excellent with the stronger-growing delphiniums. They are really good only in masses, except such as Golden Glow, which is best grouped in clumps of four or frve together for some emphatic point in the garden.

Rudbeckia fulgida. Orange Coneflower. $2 \mathrm{ft}$. August and September. This plant bears numerous heads of bright orange-vellow flowers, with deep purple disk. 75 cts. for 3, \$2.20 for $10, \$ 15$ per 100 .

R. laciniata, Golden Glow. 5 to $6 \mathrm{ft}$. July to September. A very popular hardy perennial, with masses of double bright golden yellow flowers. Fine for screening and planting near stone walls. 75 cts. for $3, \$ 2.20$ for $10, \$ 15$ per 100

R. purpurea. See Echinacea purpurea.

R. speciosa (newmanni). Sbowy Coneflower. 2 to $3 \mathrm{ft}$. July to October. Large yellow or orangeyellow flowers 3 to 4 inches across. Fine for cutting.

R. subtomentosa. Sweet Coneflower. $21 / 2$ to $3 \mathrm{ft}$. August and September. Brilliant lemon-yellow flowers with dark purple centers.

R. triloba. Brown-eved Susan. 3 to $5 \mathrm{ft}$. July and August. Dense, bushy plant with numerous-rayed, deep yellow flowers which form brilliant masses of color.

\section{RUTA}

*Ruta graveolens. Common Rue. $11 / 2$ to $2 \mathrm{ft}$. JuIy. Panicles of small, fragrant flowers and divided leaves. An old-time medicinal herb of value for association's sake. 90 cts. for $3, \$ 2.50$ for $10, \$ 20$ per 100.

\section{SALVIA}

*Salvia azurea grandiflora. Great Azure Sage. 3 to $4 \mathrm{ft}$. August and September. Plants of shrubby habit, with beautiful light blue flowers in Iong, slender spikes.

S. azurea pitcheri. 3 to $4 \mathrm{ft}$. September and October. More branching habit than above, with large flowers of rich gentian-blue. This is a very handsome and showy variety which we highly recommend. $\$ 1.05$ for $3, \$ 2.70$ for $10, \$ 20$ per 100 .

*S. argentea. Silver Sage. 2 to $3 \mathrm{ft}$. June. Large silvery foliage and white flowers.

S. officinalis. Garden Sage. 1 to $2 \mathrm{ft}$. June and July. Aromatic whitish, somewhat downy Ieaves, used for herbs and flavoring. Flowers come in whorls, varying in size and color from blue to white.

*S. pratensis. Meadow Sage. 18 to 24 in. June to September. Useful plant for borders, with violetblue flowers in showy spikes.

*S. sclarea. 2 to $3 \mathrm{ft}$. July to September. A fine graceful plant with slender spikes of clear pink or lavender-pink. Pretty with Madonna lilies and in the rock garden. $\$ 1.50$ for $3, \$ 4$ for 10 .

\section{SANGUINARIA}

* Sanguinaria canadensis. Bloodroot. 6 to 10 in. April and May. Delicate, starry, pure white flowers on soft, red, juicy stems, followed by tall, broad, gray leaves. One of the most beautifuI native wild flowers. 75 cts. for $3, \$ 2.20$ for $10, \$ 15$ per 100 .

\section{SANTOLINA}

* Santolina chamæcyparissus. Lavender Cotton. 12 in. Evergreen perennial, with attractive silverwhite foliage and yellow flowers. It is useful as a rock or border plant and largely used for massed bedding.

\section{SAPONARIA}

*Saponaria ocymoides. Rock Soapwort. 6 in. May to August. A half-trailing plant, useful for rockwork, with bright pink flowers in loose, broad cymes. Very showy and effective clambering over stones. $\$ 1.05$ for $3, \$ 2.70$ for $10, \$ 20$ per 100 .

*S. officinalis flore-pleno. Double Bouncing Bet. July and August. Pretty variety, with broad heads of double pink flowers: Fine for wild-garden. Spreads very rapidIy and is most persistent, thriving in very inhospitable soils.

\section{SAXIFRAGA}

A very interesting group of dwarf plants, chiefly valuable for rockeries or low borders. There are innumerable species and varieties, and we have assembled here what we consider the best of the various types. They are all charming and easily grown, provided they are not exposed to scorching summer heat. For that reason they are best planted in the shade of Iate-starting deciduous shrubs. Their greatest beauty is in the even, showy sheets of bloom they make when well grown in masses, and for that reason they should be planted liberally and fairly close together.

* Saxifraga aizoon. Neat little tufted plants with rosettes of silvery-edged leaves. The flowers are white, sometimes faintly tinged pink, in graceful sprays. $\$ 1.20$ for $3, \$ 3.50$ for 10 .

*S. bathoniensis alba. A mossy variety of great charm; flowers white and very freely produced. $\$ 1.05$ for 3, \$3 for 10 .

*S. cæespitosa. The true variety is very rare, the name being applied usually to hybrids. The plant is tufted, mossy and bears three or four white flowers on each of its short purplish stems. \$1.05 for 3, $\$ 2.70$ for $10, \$ 20$ per 100 .

$*$ S. cochlearis. 4 in. Massed silvery rosettes with thick recurved leaves and large showy white flowers on red stems. A very beautiful rockery plant. It likes lime. $\$ 1.05$ for $3, \$ 3$ for 10.

*S. cordifolia. Heartleaf Saxifrage. 15 in. April and May. A strong-growing species with Iarge, waxy foliage and clusters of bright rose-colored flowers on the tips of tall stems very early in the spring. Fine among Iarge rocks or ledges. $\$ 1.05$ for 3 , $\$ 3$ for $10, \$ 20$ per 100 .

*S. crassifolia. Leatber Saxifrage. 12 to 15 in. April to June. This showy, spreading plant has drooping masses of pink flowers high above the large, clustered leaves. A fine rock plant. $\$ 1.05$ for $3, \$ 2.70$ for 10 $\$ 20$ per 100.

*S. decipiens. Crimson Moss. 4 in. May, June. A mossy plant somewhat like $S$. cxspitosa with tiny white flowers. The foliage turns bright crimson in winter. A very highly prized variety for the rock garden. $\$ 1.05$ for $3, \$ 3$ for 10 .

$* \mathrm{~S}$. lingulata. 1 to $2 \mathrm{ft}$. The long, narrow, tufted leaves are fleshy and beaded with crystals of lime. The flower-spike is covered with smaller leaves and bears a branched head of tiny white flowers. One of the finest and showiest of the family. It likes limestone soil, and good, sharp drainage. $\$ 1.05$ for 3, $\$ 3$ for 10 . 


\section{SAXIFRAGA, continued}

S. MacNabiana. $1 \mathrm{ft}$. May and June. Numerous clusters of white flowers heavily speckled with large pink-purple dots. $\$ 1.05$ for $3, \$ 2.50$ for $10, \$ 20$ per 100.

*S., Mossy Varieties. 6 in. or more. Pretty cushions of bright emerald-green foliage with variable flowers. Some plants producing white flowers, others various shades of pink and red, in graceful sprays. They like shade and some moisture but must be preserved from dampness during the winter. $\$ 1.05$ for $3, \$ 2.70$ for $10, \$ 20$ per 100

*S. sarmentosa. Motber of Thousands; Old Man's Beard; Strawbern Geranium. 9 to 24 in. The main plant makes a cluster of round green leaves veined white and stained red underneath. Early in summer it throws up slender sprays of small yellow and red flowers, and Iater sends out runners like a strawberry, making cascades of pretty foliage. \$1.05 for $3, \$ 3$ for 10 .

S. virginiensis. Virginia Saxifrage. 3 to 12 in. April to June. A dainty little native varying greatly in height according to soil and moisture. It will grow on almost bare rock, producing a tiny, russet-tinted rosette of roundish leaves and a slender stem with a cluster of little white flowers. Likes a somewhat shady place. $\$ 1.05$ for $3, \$ 3$ for 10 .

\section{SCABIOSA}

These are handsome, bushy plants suited to any good border, thriving in sunny locations and producing great quantities of beautiful flowers on fine cutting stems. They should be grown in quantity for their excellent decorative effect.

Scabiosa caucasica. Caucasian Scabiosa. 18 to $24 \mathrm{in}$. June to September. Vigorous, handsome border plant with Iarge, soft lilac-blue flowers on Iong stems, useful for cutting. $\$ 1.05$ for $3, \$ 2.70$ for $10, \$ 21$ per 100 .

S. caucasica alba. Wbite Caucasian Scabiosa. A charming variety of the preceding with white flowers. $\$ 1.20$ for $3, \$ 3.50$ for $10, \$ 30$ per 100 .

S. japonica. Japanese Scabiosa. $2 \mathrm{ft}$. July to September. This Japanese variety has beautiful blue flowers in great abundance.

S. pennsylvanica. See Cephalaria tatarica.

S. sylvatica. 18 in. July to September. Flowers purple-pink and very pretty. $\$ 1.05$ for 3, $\$ 3$ for 10 .

\section{SEDUM - Stonecrop}

Of easiest possible culture, the Sedums will thrive for almost everyone, and apparently in some of the most inhospitable places. They will not endure dampness, however, and should always be planted so that their roots are high and dry. Ideal for rockeries, cracks between stones, covering bare sandy patches of sterile ground, and for innumerable places where hard-luck plants are needed.

*Sedum acre. Gold Moss. 2 to 4 in. May and June. A little, low, tufted plant with pulpy light green leaves and with masses of yellow flowers. Good for edging and covering ledges. 75 cts. for $3, \$ 2.20$ for $10, \$ 15$ per 100 .

*S. album. Wbite Stonecrop. 4 to 6 in. July and August. Very pretty creeping variety, with small foliage and tiny white flowers on pinkish stems. 75 cts. for $3, \$ 2.20$ for $10, \$ 15$ per 100 .

$* S$. anglicum. 3 in. Rose and white flowers. A rare variety of excellent, neat habit for small crevices in the rockerv.

*S. dasyphyllum. Leafy Stonecrop. 2 in. Tufted, branching plant with crowded, fleshy leaves, studded with crystals. Flowers pinkish in flat clusters. \$1.05 for $3, \$ 3$ for 10.

*S. ewersi. Ewer's Stonecrop. 4 to 6 in. September to October. Little clumps, with broad, glaucous leaves and purplish pink flowers.

*S. ewersi turkestanicum. Violet Stonecrop. 8 in. A dark violet-flowered form of the foregoing. Attractive and hardy. $\$ 1.05$ for $3, \$ 2.70$ for 10 , $\$ 20$ per 100 .

\section{SEDUM, continued}

*S. kamtschaticum. Orange Stonecrop. 6 to 9 in. July and August. Pulpy, bright evergreen foliage, with golden flowers in flat clusters.

*S. Iydium. Lydian Stonecrop. 2 in. Forms a dense carpet of bright green, turning red in dry, sunny locations. Pure white flowers on short stems. 75 cts. for 3, \$2.20 for 10, \$15 per 100 .

*S. maximowiczi. Amur Stonecrop. 12 in. A good border and rock plant, covering the earth with a dense mat of its tiny yellow flowers.

*S. maximuin. Great Stonecrop. 1 to $2 \mathrm{ft}$. September and October. A vigorous, bushy border plant with pinkish or whitish flowers.

*S. maximum hæmatodes (atropurpureum). 1 to $2 \mathrm{ft}$. September and October. Metallic brown foliage and red flowers. Very effective for borders.

*S. moranense. 3 to 4 in. A distinct, mossy variety from Mexico, with wiry stems and clusters of starry white flowers.

*S. oppositifolium (Two-row Sedum). 6 in. August. Compact, green foliage and white flowers in clusters. $\$ 1.05$ for 3, \$3 for 10 .

*S. pruinatum forsterianum. Small, trailing plant, with round bunches of tiny golden yellow flowers and bluish green leaves.

*S. reflexum. Jenny Stonecrop. 8 in. Trailing habit with erect flower-stems with clusters of yellow flowers. 90 cts. for $3, \$ 2.50$ for $10, \$ 20$ per 100 .

$\star S$. rupestre. 6 in. or more. Closely allied to $S$. reflexum in habit and appearance. Dense heads of yellow flowers.

*S. sarmentosum. Stringy Stonecrop. A slender creeping plant with whorled, thread-like leaves and flat heads of small, fleshy, yellow flowers.

*S. sexangulare. Hexagon Stonecrop. 2 to $3 \mathrm{ft}$. Very slender-stemmed massing plant, similar to $S$. acre, but with brown foliage.

*S. sieboldi. Siebold Stonecrop. 6 in. August to September. This variety has broad, bluish gray foliage, margined with pink, and rose-pink flowers. Quite showy. \$1.05 for 3, \$2.70 for $10, \$ 20$ per 100 .

*S. spectabile. Sbouy Stonecrop. 18 in. An erectgrowing plant with broad green foliage and large heads of handsome rose-colored flowers. One of the best plants for rock garden or border of shrubbery bed. 75 cts. for $3, \$ 2.20$ for $10, \$ 15$ per 100 .

*S. spectabile, Brilliant. $1 \mathrm{ft}$. September and October. A more richly colored form of $S$. spectabile, being a bright amaranth-red. 90 cts. for $3, \$ 2.50$ for $10, \$ 20$ per 100 .

*S. stoloniferum. Running Stonecrop. 4 in. July and August. A trailing plant, and one of the most desirable Sedums. It has flat, fleshy leaves and pink flowers.

*S. ternatum. Mountain Stonecrop. 3 to 6 in. May and June. A small-leaved, very spreading plant with triangular clusters or spravs of starry white flowers. A very charming sort. 90 cts. for $3, \$ 2.40$ for 10 .

\section{SEMPERVIVUM • Houseleek}

A most interesting group of plants suitable for dry walls, rockeries, and edgings. AII of them form firm, fleshy rosettes of foliage with smaller offsets, from which they derive their common name of "Hen and Chickens." Few of them bloom much in summer, and they are attractive chiefly for their very curious habit and amusing form.

Sempervivum arenarium. The plant makes small rosettes of bright green varying to crimson, and spreads rapidly. It is a fine variety where tiny plants are needed in large numbers. 75 cts. for 3 , $\$ 2.20$ for $10, \$ 15$ per 100 .

*S. arachnoideum. Spiderweb Houseleek. 6 in. A Iacy network of fine threads spreads from tip to tip of leaves, giving a cobweb effect. The flowers are bright red. Curious and very interesting plants. 75 cts. for $3, \$ 2.20$ for $10, \$ 15$ per 100 . 


\section{SEMPERVIVUM, continued}

*S. assimile. 6 in. Compact rosettes of pale graygreen leaves and large, pale pink flowers with narrow petals. 75 cts. for $3, \$ 2.20$ for $10, \$ 15$ per 100 .

*S. fauconati. 4 to 6 in. The small leaves are arranged in rosettes and the flowers are red. $75 \mathrm{cts}$. for $3, \$ 2.20$ for $10, \$ 15$ per 100 .

*S. fimbriatum. Fringed Houseleek. 6 to 10 in. Rosettes reddish at base, very downy and fringed with hairs at the tips. Flowers red, in loose spikes. Pretty. 75 cts. for 3, \$2.20 for 10, \$15 per 100.

*S. globiferum. Globe Houseleek. 6 to 9 in. Flattish rosettes of gray leaves with small yellow flowers. 75 cts. for $3, \$ 2.20$ for $10, \$ 15$ per 100 .

*S. hispidulum. Dark foliage in tiny rosettes and deep purplish red flowers. 75 cts. for 3 , \$2.20 for 10 , \$15 per 100 .

*S. potsi. 6 in. Small rosettes of dark leaves and yellow blossoms. 75c for 3, \$2.20 for 10, \$15 per 100

*S. soboliferum. Hen and Cbickens. 6 to 9 in. Compact little tufts with many loosely attached offsets which roll away and make new colonies. Pretty silvery foliage, lightly tinged bronze. Flowers yellow, in dense, fleshy spikes. 75 cts. for $3, \$ 2.20$ for $10, \$ 15$ per 100 .

*S. tectorum. Roof Houseleek. 8 to 12 in. Broad rosettes of green leaves with reddish tips and light red flowers. 75 cts. for $3, \$ 2.20$ for $10, \$ 15$ per 100

S. tectorum violaceum. Violet Houseleek. $1 \mathrm{ft}$. Olive-green rosettes tinted with violet-brown; reddish flowers. Largest of the Houseleeks. 75 cts. each, \$2.20 for $10, \$ 15$ per 100 .

\section{SHORTIA}

Shortia galacifolia. Oconee Bells. 8 in. June. A rare little evergreen plant with round, glessy green, leathery leaves from which rises a slender stem bearing fringed, nodding white flowers about half an inch across. A very dainty thing which wants acid soil and shade. \$1.05 for 3, \$3 for 10, \$25 per 100 .

\section{SIDALCEA - Prairie Mallow}

Sidalcea candida. White Prairie Mallow. 2 to $3 \mathrm{ft}$. June. A fine border plant, with Iarge, pyramidal heads of pure white flowers about an inch Iong. Thrives best in moist, Ioamy soil. 90 cts. for $3, \$ 2.40$ for 10 .

S. Rosy Gem. $4 \mathrm{ft}$. One of the finest of the new hybrid sorts. Its graceful spikes of rose-pink flowers resemble the Iarkspur. 90 cts. for $3, \$ 2.40$ for 10 , $\$ 20$ per 100 .

\section{SILENE • Catchfly}

A very pretty family of plants related to the pinks. They make showy little edgings and have very attractive flowers and foliage. Most of them are deep-rooting and will endure rock-garden conditions. The native $S$. pennsylranica is perfectly at home on dry, sterile banks.

*Silene alpestris. A showy variety with bright green glossy foliage and pure white flowers. \$1.05 for 3, $\$ 3$ for $10, \$ 24$ per 100 .

*S. schafta. Scbafta Catcbfli. 4 to 6 in. June to September. Cushion-like plant with clusters of rosepink flowers on stems springing from the rosettes of leaves. Beautiful for rock garden or edging.

"S. virginica. Fire Pink. 1 to $2 \mathrm{ft}$. June and July. Thin, erect plants with loose cluster of blazing scarlet flowers with fringed petals. A superb rock plant in moderately dry and not too shady places. 90 cts. for $3, \$ 2.40$ for 10 .

\section{SILPHIUM · Rosin Weed}

Silphium perfoliatum. Cup Rosin Weed. 6 to $8 \mathrm{ft}$. July to mid-September. Showy heads of yellow flowers.

\section{SISYRINCHIUM}

Sisyrinchium angustifolium (bermudianum). Common Blue-ered Grass. $1 \mathrm{ft}$. May to August. A very pretty grass-like plant with delicately beautiful little blue flowers. 75 cts. for $3, \$ 2.20$ for 10 , $\$ 15$ per 100 .

\section{SMILACINA}

*Smilacina bifolia (Maianthemum bifolium). 6 to 8 in. A small plant like a lily-of-the-valley, with two large leaves and a spiky spray of small white flowers.

\section{SOLIDAGO • Goldenrod}

The Goldenrods are too well known to need extensive description. They are showy at the back of borders, in meadow plantings, and along the edges of groves or thickets. For bold Iandscape effects they are unequaled, giving a mass of brilliant color from midsummer until autumn, and the dead heads are still beautiful and graceful as they sway above the winter snow.

Solidago canadensis. Canada Goldenrod. 3 to $4 \mathrm{ft}$. July to early October. A tall species that is fine for sandy, open places. The numerous flowers are golden yellow, in large, rather flat heads. 75 cts. for 3 , $\$ 2.20$ for 10 , \$15 per 100

S. rigidus. Stiff Goldenrod. 2 to $3 \mathrm{ft}$. August and September. A bold plant with Iarge, heavy foliage and immense heads of rich yellow flowers. $75 \mathrm{cts}$. for $3, \$ 2.20$ for $10, \$ 15$ per 100 .

S. rugosa. Wrinkled Goldenrod. 2 to $3 \mathrm{ft}$. August and September. Massive heads of yellow flowers and large, heavy foliage. 75 cts. for $3, \$ 2.20$ for 10 , $\$ 15$ per 100 .

S. sempervirens. Seaside Goldenrod. 2 to $3 \mathrm{ft}$. August and September. Very large leaves and large yellow flowers. One of the best Goldenrods. 75 cts. for 3 , $\$ 2.20$ for $10, \$ 15$ per 100 .

\section{SPIR EA}

For herbaceous plants commonly listed under this name see Aruncus, Astilbe and Filipendula.

\section{STACHYS • Betony}

*Stachys grandiflora. Big Betony. 12 in. June and July. A fine border plant, with heavily veined leaves and pretty spikes of rosy pink flowers.

*S. grandiflora superba. Mauve Betony. 12 to 18 in July to September. Spikes of rosy purple flowers. Fine for shrubbery border.

*S. lanata. Woolly Betony. $1 \mathrm{ft}$. July. A very useful plant for edging because of its dense, attractive, silvery white foliage which is particularly effective in showing off the small, delicately tinted, purple flowers.

\section{STATICE · Armeria}

There is much confusion in the names of these plants. Those commonly called Statice will be found under Limonium, and here are listed those plants usually found under Armeria. This nomenclature is in accord with best authorities.

They are fine rock garden or edging plants, forming dense carpets or rosettes of foliage above which their globular flower-heads sway on slender stems.

*Statice armeria (Armeria maritima). 3 to 6 in. May and June. Valuable for edging. Flowers fine lavender-pink. Foliage grass-like, evergreen. 75 cts. for $3, \$ 2.20$ for 10 , \$15 per 100 .

*S. armeria alba (Armeria maritima alba). 3 to 6 in. May and June. Tufts of deep green foliage; white flowers. 


\section{STATICE, continued}

*S. armeria laucheana. 3 to 6 in. April to June. Bright rose-colored flowers. Excellent for rock garden or edging. 75 cts. for $3, \$ 2.20$ for $10, \$ 15$ per 100.

*S. armeria laucheana robusta. 8 to 10 in. June to October. Large crimson flowers. Very useful for edging and cutting.

S. latifolia. See Limonium latifolium.

S. plantaginea leucantha (Armeria dianthoides). Wbite Plantain. $12 \mathrm{in}$. or more. Tufts of narrow foliage and Iarge, dense heads of pure white flowers.

*S. pseudo-armeria rosea (Armeria formosa rosea). 12 to 15 in. Rathe. broad leaves in Iarge rosettes and slender stems bearing brilliant pink flower-heads. 75 cts. for $3, \$ 2.26$ for $10, \$ 15$ per 100 .

*S. pseudo-armeria rubra (Armeria cephalotes rubra). 12 to 18 in. Densely tufted plants, with Iarge, rich crimson flower-heads on taII, slender stems. An exceedingly lovely and graceful plant superior to the other Armerias in all respects. Stock is always in heavy demand and consequently scarce.

\section{STENANTHIUM}

*Stenanthium robustum. Featber Fleece. 3 to $4 \mathrm{ft}$. Long, slender leaves and tall stems with showy panicles of white, feathery flowers often 2 feet long. Valuable for naturalizing in moist, shady corners. 90 cts. for $3, \$ 2.40$ for $10, \$ 20$ per 100 .

\section{STOKESIA}

Stokesia lævis (cyanea). Stokesia. 1 to $2 \mathrm{ft}$. July to October. A charming plant, with very Iarge, Iavender-blue flowers resembling the centaureas. Of great value for border and cutting.

S. lævis alba. Wbite Stokesia. A variety of the preceding with pure white flowers.

\section{TEUCRIUM}

*Teucrium chamædrys. Chamædrys' Germander $1 \mathrm{ft}$. July to September. Terminal spikes of bright rose flowers, the Iower lips spotted with red and white; evergreen foliage. An especially good plant for Iate summer bloom and in many places it is being used in place of boxwood for edging. $90 \mathrm{cts}$. for $3, \$ 2.40$ for $10, \$ 20$ per 100 .

\section{THALICTRUM • Meadowrue}

Unusually gracefuI plants, beautiful both in flower and foliage, which remain attractive throughout the whole season. The showy part of the flowers is usually the Iong, thread-like stamens which are very delicately colored, giving a most airy, foamlike quality to the bloom. Beautiful either as specimens or masses, but they look best in masses at the edge of shrubs or at the center or rear of borders, depending upon the height of the varieties chosen.

Thalictrum aquilegifolium. Columbine Meadowrue. 2 to $3 \mathrm{ft}$. May to JuIy. A very gracefuI border plant, with heads of feathery cream-colored flowers. Its finely cut foliage resembles that of the columbines. Good for rock garden.

T. aquilegifolium purpureum. Purple Columbine Meadowrue. Similar to the preceding but with showy purple stamens, giving a soft misty beauty to the flowers. $\$ 1.05$ for $3, \$ 2.70$ for $10, \$ 20$ per 100 .

T. cornutum. July to September. A strong-growing native variety with white flowers. It thrives in a wet, open place, often along brooks.

T. dipterocarpum. Yunnan Meadowrue. $4 \mathrm{ft}$. August and September. Flowers violet-mauve with lemon-yellow stamens. A very graceful, showy, and beautiful plant. \$1.05 for 3, \$3 for 10, \$24 per 100 . T. dipterocarpum album. $5 \mathrm{ft}$. A lovely new variety with pure white flowers. $\$ 1.05$ for $3, \$ 3$ for 10 T. glaucum. Dusty Meadowrue. 3 to $4 \mathrm{ft}$. JuIy. Similar in habit to $T$. aquilegifolium, with blue-gray, fine-cut foliage and heads of Chinese yellow, fragrant flowers.

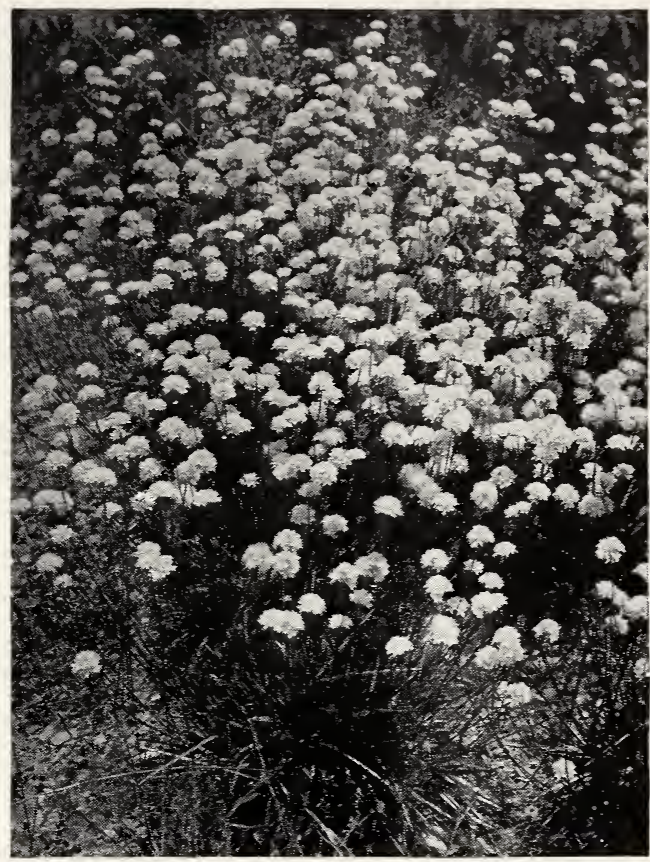

Statice pseudo-armeria rubra (Armeria cephalotes rubra)

THALICTRUM, continued

*T. minus adiantifolium. Maidenbair Meadowrue. 1 to $2 \mathrm{ft}$. June to mid-July. Grown for the foliage, which is grayish and resembles that of the maidenhair fern. Charming in the border as edging or in rock garden.

T. sulfureum. Sulphur Meadowrue. A hybrid variety from the famous hybridizer Lemoine. It bears immense panicles of charming sulphur-yellow flowers.

\section{THERMOPSIS}

Thermopsis caroliniana. Carolina Tbermopsis. 3 to $4 \mathrm{ft}$. June and July. A tall plant with bright yellow, pea-shaped blossoms along the upper part of the stalk, and clover-like foliage. Fine for wild-garden or half-shady places in the shrubbery. $\$ 1.20$ for 3 , $\$ 3$ for $10, \$ 24$ per 100.

T. mollis. Soft Thermopsis. 2 to $3 \mathrm{ft}$. Mid-May to August. Erect, branching plant with yellow flowers in showy spikes. A good border subject. $\$ 1.20$ for 3, \$3 for 10, \$24 per 100 .

\section{THYMUS - Thyme}

Tiny, old-fashioned sweet herbs valuable for edging, stone work, and Iow carpet bedding. Thymus serpyllum is usually evergreen. Splendid for steps and walks for the fragrance exhaled when the plants are brushed or bruised.

*Thymus serpyllum. Motber-of-Tbyme. 6 in. Creeping, evergreen plant much prized for edging, rockwork, and ground-cover. It has tiny. Iilac flowers and odorous leaves used for seasoning. A very leafy and attractive plant.

*T. serpyllum album. Wbite Motber-of-Tbrme. 2 to 4 in. June to August. A pretty subject for rockery with dark green foliage and little white flowers. $\$ 1.05$ for 3, \$2.70 for 1.0 , \$20 per 100 .

*T. serpyllum citriodorus. Lemon-scented Tbyme. 4 in. Very similar to the common Thyme, with tiny pink flowers and sweet foliage. Excellent for rock garden. 


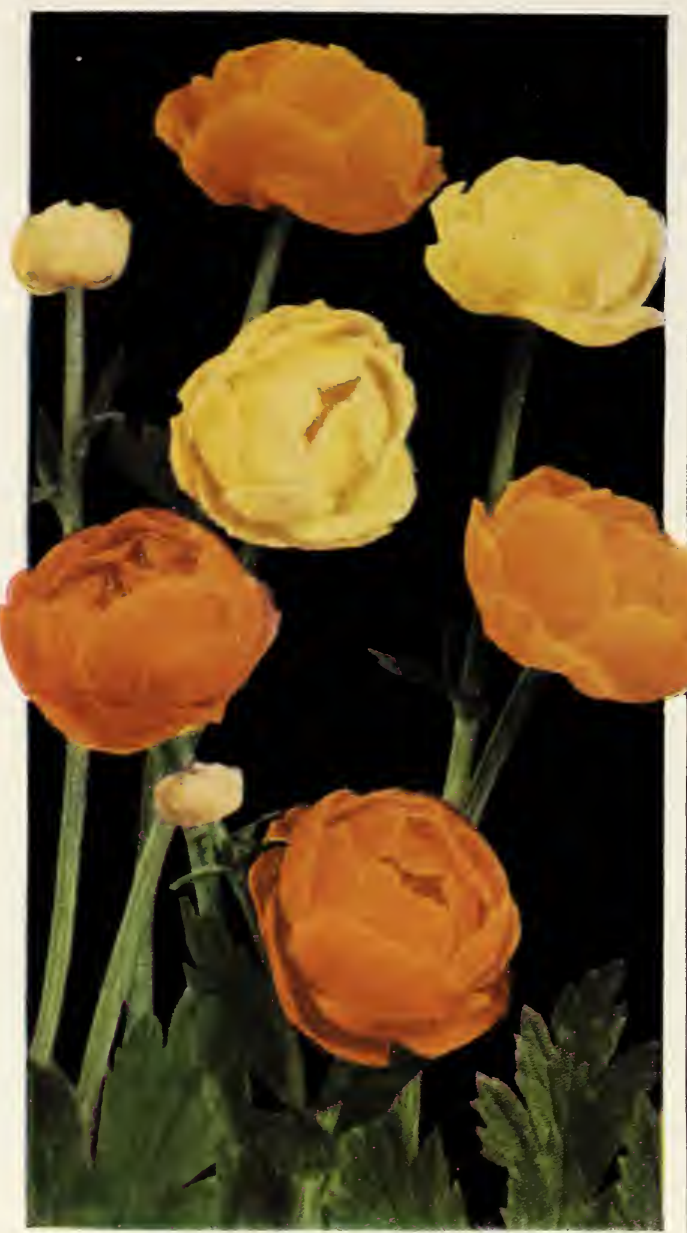

Trollius. The orange is Excelsior; the yellow is Eleanor

THYMUS, continued

*T. serpyllum coccineus. Crimson Tbyme. 2 to 4 in. Similar in form to preceding with bright crimson flowers. $\$ 1.05$ for $3, \$ 2.70$ for $10, \$ 20$ per 100

*T. serpyllum lanuginosus. Woolly Tbyme. 3 to 4 in. June to August. Downy gray foliage. Effective for compact carpeting and edging.

*T. serpyllum roseus. 4 in. A rare form of the Common Thyme making a lovely carpet of pure pink in early summer. \$1.05 for 3, \$2.70 for $10, \$ 20$ per 100 .

*T. serpyllum vulgaris. Common Tbyme. 6 in. June and July. It is grown as a sweet herb. The small, Iilac or purplish flowers are borne in terminal, interrupted spikes. Foliage very fragrant. Fine for rock garden.

\section{TIARELLA}

*Tiarella cordifolia. Allegbeny Foam Flower. 6 to 12 in. May. An elegant plant with fine foliage and smaII, creamy white, star-shaped flowers in clusters on slender stems. A fine plant for naturalizing.

\section{TRADESCANTIA}

Tradescantia virginiana. Virginia Spiderwort. $2 \mathrm{ft}$. An old garden plant, with grass-like foliage and violet-blue flowers all summer.

T. virginiana alba. Wbite Spiderwort. White. 75 cts. for $3, \$ 2.20$ for 10 , $\$ 15$ per 100 .

T. virginiana rosea. Pink Spiderwort. 12 in. Slender, smooth-stemmed with rose-pink flowers. $\$ 1.05$ for 3 , $\$ 3$ for 10 , \$25 per 100 .

\section{TRILLIUM}

*Trillium grandiflorum. Snow Trillium. 9 in. May. The large, white, three-petaled, lily-like flowers nod at the center of a cluster of three big leaves and change to rosy pink as they fade. Fine for planting in shade. 75 cts. for $3, \$ 2.20$ for 10 , $\$ 15$ per 100

*T. erectum. Purple Trillium. $1 \mathrm{ft}$. or more. The flowers are smaller than the preceding and brownish purple, sometimes tinted green. $75 \mathrm{cts}$. for 3 , $\$ 2.20$ for 10 , \$15 per 100 .

\section{TRITOMA. See Kniphofia}

\section{TROLLIUS}

Very showy flowers of globular shape, resembling giant buttercups. They like damp places, not necessarily shaded as some of them develop their best colors only in sunlight. They are splendid for massing along water-courses for display, and are equally good in the garden for cut-flowers.

Trollius asiaticus. Siberian Globeflower. 1 to $11 / 2 \mathrm{ft}$. May and June. Large orange flowers on leafy stems which are suitable for cutting. 50c. each, $\$ 4$ for 10 . T. asiaticus giganteus. Similar to $T$. asiaticus, but much taller and stronger. $50 \mathrm{cts}$. each, $\$ 4$ for 10 , $\$ 36$ per 100 .

T. europaeus. Common Globeflower. 1 to $11 / 2 \mathrm{ft}$. May to August. A valuable border perennial, with large, globular, lemon-yellow buttercup-like flowers on long stems. $\$ 1.20$ for 3, \$3.50 for $10, \$ 25$ per 100 .

T. europaeus, Eleanor. 18 inches. Flowers clear yellow and double the size of $T$. europaeus. A fine variety. 50 cts. each, $\$ 4$ for $10, \$ 30$ per 100 .

T. europaeus japonicus. Japanese Globeflower. 8 to 12 in. Beautiful, semi-double orange-yellow flowers. 50 cts. each, $\$ 4$ for 10.

T. europaeus loddigesi. Goldenball Trollius. Similar to $T$. europaeus but has larger and deep yellow flowers. $50 \mathrm{cts}$. each, $\$ 4$ for 10.

T. europaeus, Orange Globe. $2 \mathrm{ft}$. June to August. A strong, sturdy grower, with Iarge, globular flowers of a rich, deep glowing orange. Free blooming. $50 \mathrm{cts}$. each, $\$ 4$ for $10, \$ 36$ per 100 .

T. europaeus japonicus, Excelsior. $2 \mathrm{ft}$. Rich orange flowers. $50 \mathrm{cts}$. each, \$4 for 10.

T. ledebouri. Ledebour Globeflower. A giant in the family, 3 feet or more tall. Flowers orange-yellow, spread open more than other sorts. 40 cts. each, $\$ 3.50$ for $10, \$ 30$ per 100 .

\section{TUNICA}

*Tunica saxifraga. Saxifrage Tunic Flower. 6 in. Blooms all summer. A dwarf, tufted rock plant with pinkish flowers and most delicate foliage.

*T. saxifraga alba. A white-flowered form of the above.

\section{VALERIANA}

Valeriana officinalis. Garden Heliotrope. $4 \mathrm{ft}$. June. Numerous trusses of pinkish Iavender flowers with a delicate vanilla fragrance. Foliage showy.

V. centranthus. See Centranthus ruber.

\section{VERBASCUM • Mullein}

The Mulleins are bold, showy plants, very effective in naturalistic planting and for emphatic effects in the wilder part of the garden. Their foliage is striking and makes a beautiful contrast with the brighter leaves of other perennials.

Verbascum densiflorum (thapsiforme). 4 to $6 \mathrm{ft}$. June and July. The yellow flowers have mahogany centers and are clustered along the much-branched stems.

V. hybridum, Miss Willmott. $6 \mathrm{ft}$. A very beautiful variety with large, pure white flowers produced on picturesque plants over a long season. 


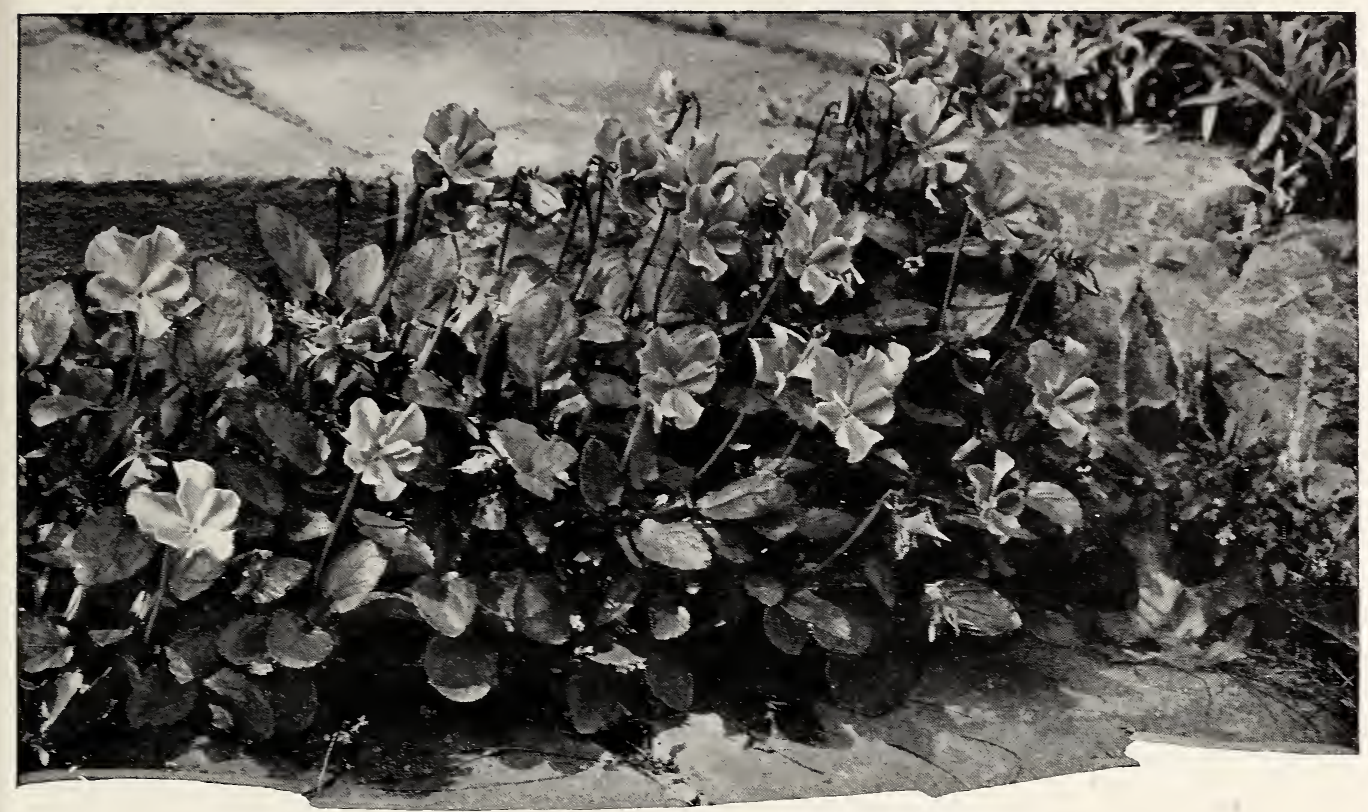

Viola, Jersey Gem, tucked in the corner of the garden steps

\section{VERBASCUM, continued}

V. longifolium pannosum. Golden Gate Mullein. 3 to $4 \mathrm{ft}$. A very vigorous, woolly plant with tall, showy spikes of sulphur-yellow flowers.

V. olympicum. Olympic Mullein. 6 to $10 \mathrm{ft}$. JuIy. A stately variety, with large, woolly, silvery white foliage and bright yellow flowers in branching spikes.

V. phœniceum. Purple Mullein. 2 to $3 \mathrm{ft}$. Flat rosettes of crinkly leaves from which rise slender spikes of beautiful mauve-purple and rosy violet flowers. Showy and very desirable. $\$ 1.05$ for 3 , $\$ 3$ for $10, \$ 20$ per 100 .

\section{VERBENA}

Verbena hastata. Blue Verrain. 4 to $6 \mathrm{ft}$. August and September. This bold, wiry plant has tough, narrow leaves and long, slender spikes of rich, intensely blue-violet flowers. Showy in meadow or wild-garden.

\section{VERNONIA - Ironweed}

Vernonia crinita (arkansana). Bur Ironweed. $5 \mathrm{ft}$. September. Large heads of purple flowers.

V. noveboracensis. Common Ironueed. 3 to $6 \mathrm{ft}$. July to September. One of the noblest and showiest of our native flowers. A tough and rather coarse plant with beautiful heads of violet and purple blooms. Contrasts especially well with groups of helianthus.

\section{VERONICA · Speedwell}

A Iarge and very interesting family varying from creeping rock plants to husky shrubs. They all do well in rather moist soil and half shade, but prefer the fulI sunlight. In masses they make a vivid splash of rich blue in their season, and the foliage of all of them is attractive after their flowers are gone.

*Veronica gentianoides. Gentian Speeduell. 9 to 12 in. May. One of the earliest and most valuable border plants. It has attractive pale blue flowers with darker streaks.

\section{VERONICA, continued}

*V. incana. Woolly Speeduell. $1 \mathrm{ft}$. July and August. A white woolly plant with numerous blue flowers. It is of good appearance both in and out of bloom. Useful in rockery or border.

V. longifolia alba. Wbite Beacb Speeduell. 1 to $11 / 2 \mathrm{ft}$. July to September. A strong, Ieafy plant, with upright spikes of pure white flowers. \$1.05 for 3 , \$2.70 for 10 , \$20 per 100 .

V. longifolia subsessilis. Clump Speeduell. $2 \mathrm{ft}$. July to September. One of the handsomest blueflowering plants. It is perfectly hardy and increases in strength and beauty each year. Spikes completely studded with beautiful blue flowers. Fine for cutting and one of the best plants for the hardy border. $\$ 1.20$ for $3, \$ 3.50$ for 10 .

V. longifolia, Blue Jay. 3 to $4 \mathrm{ft}$. A handsome variety with the glorious blue-violet color of $V$. spicata and the general habit and foliage of subsessilis. $\$ 1.20$ for $3, \$ 3.50$ for $10, \$ 25$ per 100 .

*V. repens. Creeping Speeduell. 3 to 4 in. May and June. A useful rock or carpeting plant with light blue flowers, as it covers bare spaces rapidly. It prefers a moist situation but does well in dry soil. $\$ 1.05$ for $3, \$ 2.70$ for $10, \$ 20$ per 100 .

*V. rupestris. Rock Speeduell. 4 in. May and June. An excellent plant for carpeting rockeries or bare spots. Dense spikes of blue flowers. $\$ 1.05$ for 3 , $\$ 2.70$ for $10, \$ 20$ per 100 .

*V. rupestris, Heavenly Blue. A splendid light blue form. $\$ 1.20$ for $3, \$ 3.50$ for $10, \$ 30$ per 100 .

V. rupestris rosea. $2 \mathrm{ft}$. June to September. A much-branched variety with pink flowers. $\$ 1.05$ for $3, \$ 2.70$ for $10, \$ 20$ per 100 .

$* V$. rupestris Trehani. Of same general type as $V$. rupestris but the foliage makes a lovely show of greenish gold. $\$ 1.05$ for $3, \$ 3$ for 10 .

V. spicata. Spike Speeduell. $18 \mathrm{in.} \mathrm{June} \mathrm{and} \mathrm{July.}$ Long spikes of violet-blue flowers. One of the best plants for a sunny border.

V. spicata alba. Wbite Speeduell. A similar variety with long spikes of snowy white flowers.

*V. spuria (amethystina). Bastard Speeduell. $2 \mathrm{ft}$. May and June. A slender, upright, leafy plant, with many narrow spikes of dark blue flowers. One of the best varieties for rockwork. 
VERONICA, continued

*V. spuria, Royal Blue. $1 \mathrm{ft}$. May and June. A bushy plant with a great abundance of bright blue spikes. Very showy. $\$ 1.05$ for $3, \$ 2.70$ for 10 .

*V. spuria, True Blue. 10 to 12 in. June to August. A new variety of dense habit with clear, dark blue flowers. $\$ 1.05$ for $3, \$ 2.70$ for 10 .

V. virginica. Culver's Pbisic. $3 \mathrm{ft}$. or more. August and September. An erect plant with terminal spikes of pale blue flowers. Good for wild-gardens.

V. virginica alba. $4 \mathrm{ft}$. A similar form with erect spikes of white flowers.

\section{VINCA}

Vinca minor. Common Periuinkle. See Evergreen Shrub Section.

\section{VINCETOXICUM. See Cynanchum}

\section{VIOLA}

The Violet family is large and contains many useful and showy plants. Besides several distinctive species, we list a choice selection of varieties of the beautiful Violas. These are especially good for edging in rather moist, half-shady places. They are excellent at the edge of rose-beds and just at the edge of low-growing shrubs.

*Viola bosniaca. 4 in. A distinct alpine species with very pretty rosy pink flowers. $\$ 1.05$ for $3, \$ 3$ for 10 , \$20 per 100 .

*V. cornuta. Tufted Pansy. 8 in. April till frost. A hardy variety with large, pale blue flowers of violet form. A fine border plant. For various hybrid varieties, see Tufted Pansies.

*V. cornuta alba. (Type.) Wbite Tufted Pansr. Large, white-flowered variety of above. A constant bloomer.

V. cornuta, Apricot. Deliciously colored flowers of soft apricot throughout, tinted orange at center. A fine bloomer and exceedingly beautiful. 90 cts. for $3, \$ 2.40$ for $10, \$ 21$ per 100

*V. cornuta atropurpurea. (Type.) Purple Tufted Pansy. Deep violet-blue tluwers with distinct violet fragrance. Blooms all summer. One of the best for border or rock garden.

V. cornuta, Black Knight. Glossy black flowers of striking appearance. This and Apricot are each unique and extremely valuable plants. 90 cts. for $3, \$ 2.40$ for $10, \$ 21$ per 100 .

\section{VIOLA, continued}

*V. cornuta, G. Wermig. 8 in. Dark blue flowers on long stems. 90c. for 3, \$2.40 for 10, \$20 per 100.

V. cucullata. Blue Marcb Violet. 8 in. April and May. Dark blue flowers, freely produced on long stems. Fine for planting in shade. 75 cts. for 3, $\$ 2.20$ for $10, \$ 15$ per 100 .

V., Jersey Gem. 8 in. An improved variety with showy violet-blue flowers which are produced more freely and over a longer season than most kinds. It is also very resistant to hot weather. $\$ 1.05$ for 3 , $\$ 3$ for $10, \$ 20$ per 100 .

V., Jersey Gem, White. A charming pure white sport of the popular Jersey Gem, with the same profusion and perennial habit. \$1.05 for $3, \$ 3$ for 10 .

V. odorata, Gov. Herrick. 3 to 6 in. Apri! to June. Fine, large flowers of clear blue, moderately fragrant.

V. odorata, Single Russian. Sweet Violet. t to 8 in. May to October. Fine flowers of rich fragrance produced at intervals all summer.

V. odorata, Double Russian. A lovely double form of the preceding. Flowers large and richly fragrant. $\$ 1.20$ for 3, \$3 for 10, \$24 per 100 .

*V. pedata. Bird's-foot Violet. 6 in. One of the best wild flowers and one of the first to bloom. Deep purple flowers and fine-cut leaves.

\section{Tufted Pansies (Viola cornuta)}

The following varieties of Tufted Pansies are the result of hybridizing Viola cornuta with other species. They are somewhat showier than the straight Cornuta varieties but generally less compact in habit.

75 cts. for 3 of one kind, $\$ 2.20$ for $10, \$ 15$ per 100

Admiration. Rich dark blue.

Blue Perfection. Mauve, yellow eye.

Lutea. Golden yellow.

Mauve Queen. Fine reddish violet.

Papilio. Similar to Cornuta in color but larger and more wavy.

Purple Queen. Purplish violet. Fine.

White Perfection. A fine white flower.

\section{YUCCA}

*Yucca filamentosa. Common Yucca. 4 to $5 \mathrm{ft}$. June and July. Very ornamental, sword-like foliage and tall spikes of fragrant, drooping, bell-shaped, creamy white flowers. A showy landscape plant for bold effects. 2-yr. plants, $90 \mathrm{cts}$. for 3, \$2.40 for $10, \$ 18$ per $100 ; 3$-yr. plants, $\$ 1.05$ for $3, \$ 3$ for $10, \$ 20$ per 100 .

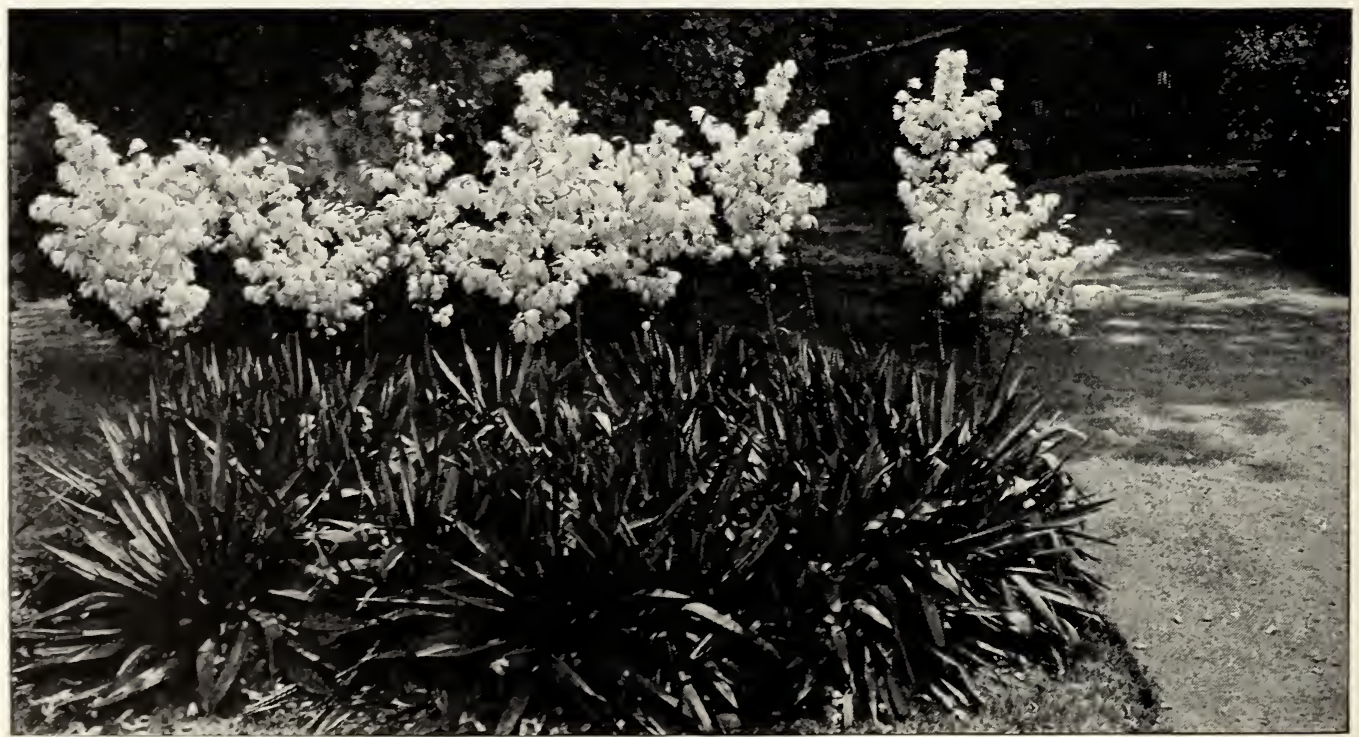

Yucca flamentosa is a fine and stately plant for formal masses 


\section{FRUIT TREES}

\section{APPLES \\ Standard Apples}

The trees we offer have all been inspected for trueness of name, although not all individually certified.

2-yr. trees, 5 to $7 \mathrm{ft}$., 11/16-in. cal., $\$ 1$ each, $\$ 9$ for $10, \$ 85$ per 100

Baldwin. Famous variety which originated near Boston about 1740. Yellow fruits almost completely overlaid with dark red; very crisp, snappy flavor; good for eating and cooking-keeps long and ships well.

Cortland. A fine new bright red variety resembling the famous McIntosh Red, with the same fine flavor, but keeps in fine condition until late in the winter.

Delicious. Very popular autumn and early winter variety of superb quality. Fruits Iarge, conical and striped red and yellow.

Golden Russet. An ancient English golden brown, Iong winter-keeping variety of excellent quality.

Gravenstein. A delicious red and yellow autumn variety of superb cooking quality.

McIntosh Red. Large, firm, well-flavored variety of bright red, for autumn and early winter use.

Porter. A fine eating and cooking Apple of bright yellow, tinged with red, for autumn and early winter use. Originated in Massachusetts about 1800.

Red Astrachan. A bright red early Apple for summer. Quick growing and early bearing.

Rhode Island Greening. Very popular, high-grade, midwinter Apple, both for cooking and dessert. Fruits green and yellow.

Roxbury Russet. Similar to GoIden Russet but a little Iarger, less acid in flavor, and a Ionger keeper.

Stayman's Winesap. A handsome late winter variety of excellent cooking quality and weIl liked everywhere.

\section{Certified Apples}

Our 3-year and 4-year Apple Trees have aII been certified individually as to trueness of name by Prof. J. K. Shaw, of the Massachusetts AgriculturaI College.

\section{3-yr. trees, 5 to $7 \mathrm{ft}$., $\$ 1.50$ each, $\$ 13.50$ for 10}

Baldwin. Described above.

Delicious. Described above.

Fameuse. From October until midwinter a splendid bright red eating Apple of delicious flavor and attractive appearance.

Golden Sweet. Prized for family use in Iate summer and autumn; very sweet and tender.

Gravenstein. Described above.

McIntosh Red. Described above.

Northern Spy. Very large red and yellow striped fruits of rich juicy quality. One of the best midwinter Apples grown for eating and cooking.

Red Astrachan. Described above.

Rhode Island Greening. Described above.

Roxbury Russet. Described above.

Stayman's Winesap. Described above.

Tolman Sweet. Small uniform fruit of frrm quality, popular for culinary use in Iate autumn and early winter.

Williams' Early Red. A pretty red Apple of excellent flavor. Very popular for home use in August and September.

Yellow Transparent. Bright greenish yellow, early summer Apple of good quality for eating and cooking.

\section{Dwarf Apples}

2-yr. trees, $\$ 1.25$ each, $\$ 11$ for 10

See description under Standard and Certified Apples.
Baldwin
Delicious
McIntosh Red
Red Astrachan
Rhode Island Greening
Yellow Transparent

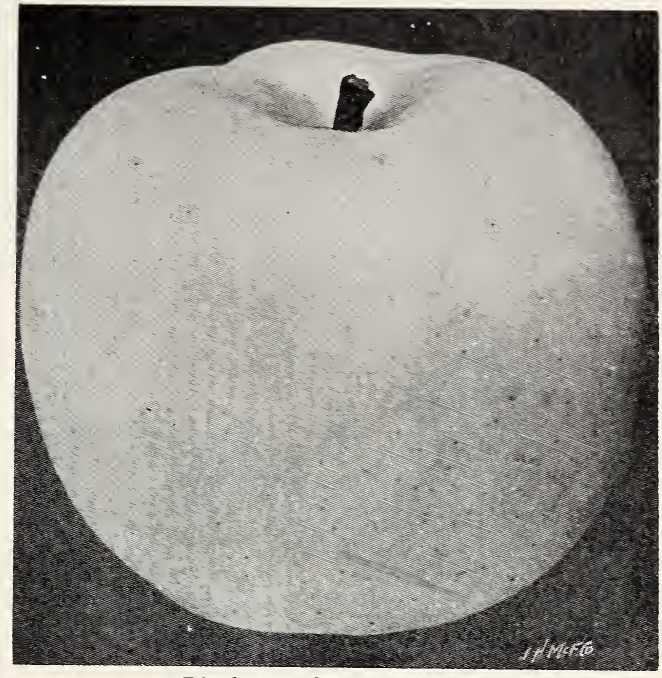

Rhode Island Greening Apple

\section{Crab-Apples}

2-yr. trees, 5 to $7 \mathrm{ft}$., $\$ 1$ each, $\$ 9$ for 10

Hyslop. Dark red or purplish fruits. One of the bestknown Crabs. Late September and October.

Martha. Large, clear yellow tinged red; crisp, juicy and excellent flavor. September to November.

Transcendent. Beautiful red and gold fruits of high quality in August and September.

\section{CHERRIES}

2-yr. trees, 5 to $7 \mathrm{ft.,} 11 / 16$-in. cal., $\$ 1.50$ each, $\$ 14$ for 10

Black Tartarian. The favorite back sweet Cherry of New England. Early ripening.

Governor Wood. Handsome, yellow-white, sweet fruits of the best flavor. Excellent for home use.

Montmorency. The standard sour Cherry for home and market. Extremely productive, hardy, and of excellent flavor. Ripens early.

Napoleon Bigarreau. The largest white sweet Cherry. BeautifuI fruits of excellent flavor.

Windsor. A firm, free-bearing, dark maroon fruit of excellent quality.

Yellow Spanish. The oIdest and one of the best with red and yellow sweet Cherries of superb quality.

\section{PEACHES}

1 -yr. trees, 4 to $5 \mathrm{ft}$., $75 \mathrm{cts}$. each, $\$ 6$ for $10, \$ 50$ per 100

Belle of Georgia. Very beautiful fruit of fair quality, maturing in midseason.

Champion. A most delicious white-fleshed Peach for home use. Early midseason.

Crawford Early. This delicious early golden yellow variety is of wonderful quality, but an erratic bearer.

Crawford Late. The finest quality of aII American yellow Peaches. Late-ripening.

Elberta. Most popular of aII Peaches for its keeping and marketing qualities. Midseason.

J. H. Hale. A splendid new sort, better than Elberta in size, earliness, and flavor. 


\section{PEARS}

\section{Standard Pears}

3 -yr. trees, 5 to $7 \mathrm{ft}$., $\$ 1.50$ each, $\$ 14$ for 10

Bartlett. Most popular of all Pears for dessert and canning. Matures in September. Fine shape, colo and excellent flavor.

Beurre Bosc. A favorite russet-gold Pear of elegant shape and exquisite flavor. Makes a handsome tree and bears abundantly, ripening in October and November.

Clapp's Favorite. Equal to Bartlett in appearance and flavor, but matures a week or two earlier. Excellent for home use.

Seckel. The most delicious of all Pears and popular the country over. Fruits are small, russet-brown, and borne abundantly. Ripens in October.

Sheldon. A handsome, beautifully colored fruit of ligh quality, ripening in October. Fine for domestic use or home market.

Winter Nelis. The standard winter Pear in this country. Medium size; excellent flavor; keeps well into January.

\section{Dwarf Pears}

3-yr. trees, $\$ 1.50$ each, $\$ 12.50$ for 10

Bartlett. Described under Standard Pears.

Clapp's Favorite. Described under Standard Pears.

Duchesse d'Angouleme. Very large, solid fruits of superb buttery flavor, ripening in October and November.

Seckel. Described under Standard Pears.

\section{PLUMS}

\section{2-yr. trees, $\$ 1.50$ each, $\$ 14$ for 10}

Abundance. Pinkish red fruits with golden flesh; very juicy and sweet. Early.

Bradshaw. One of the most popular blue Plums. Fruits Iarge; flesh yellow, of excellent flavor. Midseason.

Burbank. Larger fruits and better quality than Abundance, which it resembles in color and shape.

Italian Prune. The most popular Plum in the world. Beautiful blue fruits of delicious flavor.

Lombard. An extremely adaptable tree succeeding everywhere, with excellent pinkish purple fruits of fair quality.

Reine Claude. An old and valued Plum of great richness of flavor and abundance. Fruits yellow-green. Midseason. Frequently called "Green Gage."

Shropshire Damson. One of the best Plums for culinary purposes. A favorite for both home and market.

\section{QUINCES}

Trees, 4 to $5 \mathrm{ft}$., $\$ 1.25$ each, $\$ 11$ for 10

Champion. Prolific, constant bearer, with Iarge, oval fruits of fine quality. Ripens late and keeps long.

Meech's Prolific. Large, bright orange-yellow, delightfully fragrant fruits produced in abundance. Orange. Heavy bright yellow fruits of excellent flavor. Ripens in October.

Rea's Mammoth. Similar to Orange, averaging larger, of the same handsome form and color. Prolific.

\section{Small Fruits}

\section{BLACKBERRIES}

\section{$\$ 1.25$ for $10, \$ 10$ per 100}

Eldorado. A very early main-crop variety, with large, handsome fruits of exceptionally high quality. Very hardy and much prized for home and local market.

Erie. Extremely large, handsome berries, well-flavored if allowed to ripen on the plant. Midseason variety.

Rathbun. A productive early variety with large, handsome fruits of very good quality. Should be planted with another variety for cross pollenization.

Snyder. A standard old-time commercial variety, ripening in late midseason.

\section{GRAPES}

3 -yr. plants, 60 cts. each, $\$ 5$ for $10, \$ 45$ per 100 , except as noted

\section{Blue and Black Varieties}

Campbell's Early. A handsome, prolific variety similar to Concord, but earlier.

Concord. The standard American Grape. Popular everywhere for all purposes. 4-yr. plants, 90 cts. each, $\$ 7.50$ for 10 .

Worden. A handsome black Grape, larger and with better flavor than Concord.

\section{Red Varieties}

Catawba. Late-ripening red variety of excellent flavor. Delaware. A small plant bearing tiny bunches of medium-sized berries of delicious flavor.

\section{White Varieties}

Green Mountain. Clear green or yellowish fruits in slender clusters. Very fine quality. 75 cts. each.

Niagara. Large, handsome bunches, similar to Concord, but of delicious flavor and clear greenish white.

\section{RASPBERRIES}

Columbian. A handsome purple hybrid between the red and black varieties. Large, firm, handsome berries of high quality. Strong plants, $\$ 1.25$ for 10 , \$10 per 100.

Cumberland. Fine shipping variety of excellent size and good flavor. Strong plants, $\$ 1.25$ for $10, \$ 10$ per 100.

Cuthbert. The most popular red Raspberry, adaptable to all soils and climates. Beautiful berries of excellent keeping and shipping qualities. Strong plants, $\$ 1.25$ for $10, \$ 10$ per 100 .

Golden Queen. The finest yellow variety and very richly flavored and productive. Strong plants, $\$ 1.50$ for $10, \$ 12$ per 100 .

Herbert. An exceedingly heavy bearer of fine quality, better than Cuthbert in all respects except shipping. Strong plants, $\$ 1.25$ for $10, \$ 10$ per 100 .

Latham. A recent bright red variety of excellent quality which blooms and fruits late in the season. Strong plants, \$2 for 10 , \$18 per 100 .

Ranere. Popular everbearing variety of exceedingly vigorous growth. The fruits are small and produced all season. Strong plants, $\$ 1.25$ for $10, \$ 10$ per 100 .

\section{STRAWBERRIES}

Aroma. A splendid commercial berry of uniform size, and an excellent keeper and shipper. Adapted to many soils. Late. Runner plants, $\$ 1$ for $25, \$ 2.50$ per $100, \$ 20$ per 1000 .

Marshall. Exceedingly high-flavored, and a good cropper when well cultivated. Midseason. Runner plants, $\$ 1$ for $25, \$ 2.50$ per $100, \$ 20$ per 1000 .

Mastodon. An Everbearing Strawberry of extraordinary size and delicious quality. It bears its bright red fruits in great abundance. Runner plants, $\$ 1.50$ for $25, \$ 3.50$ per $100, \$ 30$ per 1000

Progressive. The best-known Everbearing Strawberry. Produces an excellent crop in the spring and autumn. Runner plants, $\$ 1$ for $25, \$ 2.50$ per $100, \$ 20$ per 1000 .

Senator Dunlap. A favorite market and garden variety of high quality and handsome appearance. Early. Runner plants, $\$ 1$ for $25, \$ 2.50$ per 100 , \$20 per 1000 .

\section{ASPARAGUS}

2 -yr., $\$ 1$ for $25, \$ 3$ per 100 ; 3-yr., $\$ 1.50$ for 25 , $\$ 4.50$ per 100

Conover's Colossal Martha Washington Giant Argenteuil Palmetto

\section{RHUBARB}

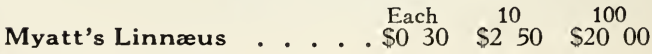




\section{INDEX}

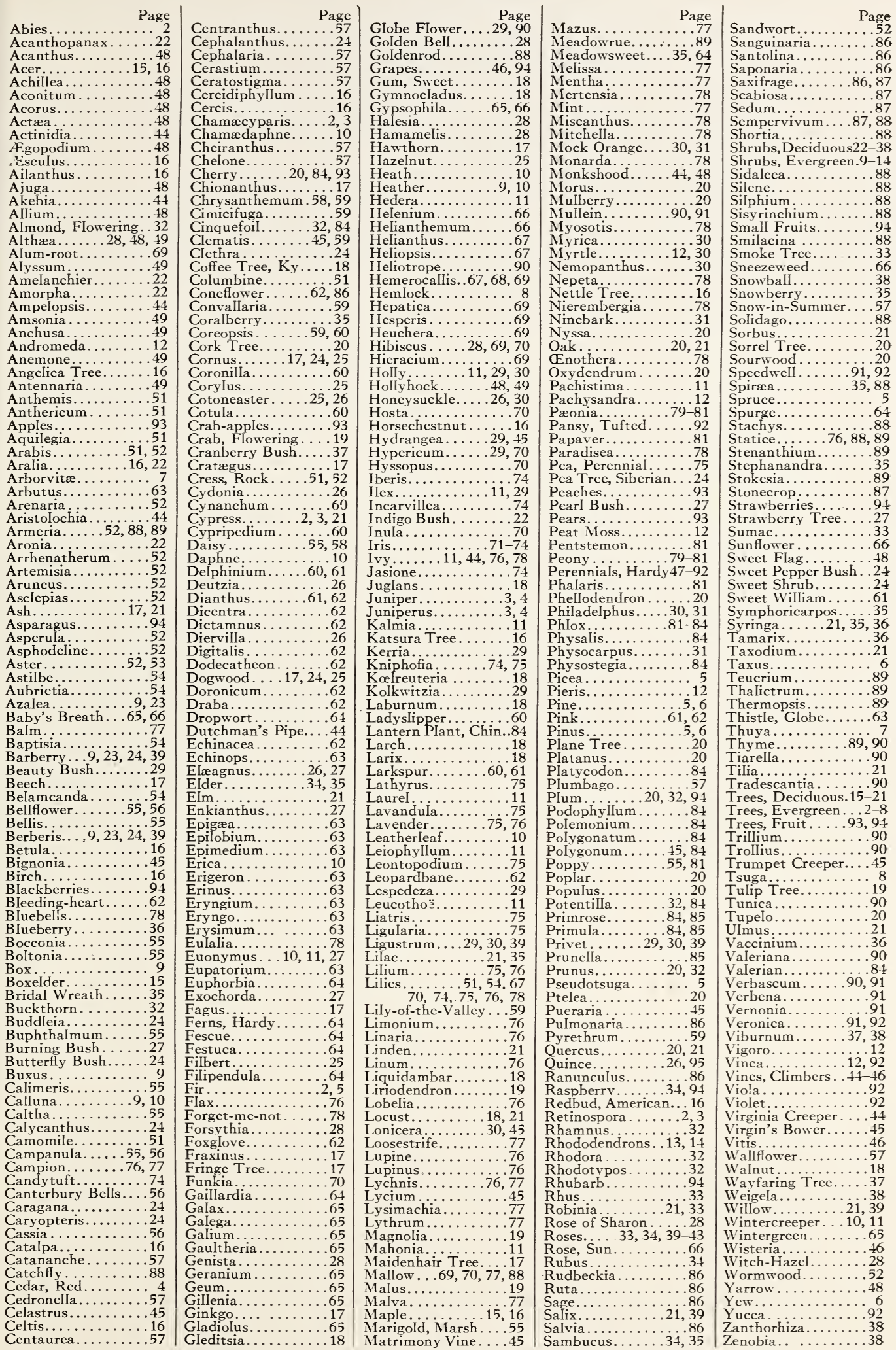




\section{Planting and Care}

\section{The Time to Plant}

The great bulk of planting is done in springthe earlier, the better. Many herbaceous perennials, and most shrubs, fruit trees, and shade trees, are successfully planted at that time. Evergreens, however, are best moved in early autumn, before the middle of October. Autumn planting is also recommended for shrubs, deciduous trees, and roses, particularly the hardy climbing roses and the shrubby types. Perennials may be planted in September, giving them time to become established before winter.

\section{How to Plant}

To a person not experienced in planting trees, it seems quite a task, but in reality it is not difficult. More plants are killed by intended kindness than by willful neglect. Some people are so fussy in planting that they needlessly consume a great deal of time setting a single tree, while there are others drying up awaiting their turn. Do not dig the holes until the plants are on the ground and ready to be put in. A fresh hole for every plant. Plants must not be allowed to remain on top of the ground in the sun, but must be taken one by one from the boxes, or all at one time, and heeled into the ground properly, to be removed as wanted for planting. Dig the holes sufficiently large so that the roots may spread out laterally in their naturaI position without cramping. Do not dig the holes too deep or too shallow-the collar on the plant will indicate how deeply it was planted in the ground before it was taken up.

Set it about one inch deeper. Use only wellpulverized loam in filling in around the roots. No sods or manure should be used under any circumstances. Shake the soil in gradually and jostle the tree or plant until every crevice is filled and no air-chambers left. In case of trees that are too large to be jostled, it is often necessary to tamp the dirt with a hoe handle or other smooth stick that will not injure the roots. After the roots have been well covered in this way, the ground should be thoroughly firmed and the hole filled again and the second time trodden. Do not be afraid of making the ground too firm around the roots. The final filling should be Ieft without treading. When trees or shrubs are planted in this way, there is little danger of their dying.

\section{Puddling}

In case it is very dry, dip the roots into a thick mud paste before planting. This is known as "puddling" the roots. If the season is wet, it is not necessary.

\section{Mulching}

We strongly recommend mulching freshly planted trees and shrubs with manure. It conserves moisture, furnishes food for the plants, and renders watering unnecessary except in unusually dry periods.

\section{Formulas for Spraying}

Formulas can be had at aII of the Agricultural Experiment Stations throughout the United States, and bulletins containing the most efficient and up-to-date methods of applying the same.

\section{Planting Evergreens}

It is no more difficult to plant evergreens than deciduous trees, but extra care must be taken that the roots are not allowed to become dry. A few special hints are given in the section of this catalogue devoted to them.

\section{How to Lay Out an Estate}

First of all, look at the place in its entirety, as you look upon a picture that you are about to frame, and seek to produce the same effect with planting as the frame produces upon the picture. Arrange the planting so that it will balance, not too heavy at one place and too light at another. Don't scatter shrubs all over the place. If the estate is large, consult a landscape architect. It will save you money. If you don't know where to find one, write to us, and we will put you in touch with a thoroughly reliable architect, as we know scores of them.

If the house is set high on its foundation, make a planting on both sides of the front door, to give the entrance a setting. Arrange a planting at the corners and along the outer sides. On the lawn, set a few ornamental trees, deciduous and evergreen, to give character and dignity to the place; but miscellaneous shrubs scattered aimlessly over the place give neither character nor dignity.

Heights must be taken into account in selecting perennials. Arrange them to have something in bloom continuously through the season. This can be done. Last of aII, take into account foliage effects and autumn tintings. Never plant hybrid tea roses on the front lawn; they should be planted in the rear, in beds, not scattered about, one here and one there.

\section{A Final Word About Evergreens}

Both broad and narrow-leaved evergreens are being planted more and more, because they give a warm, comfortable appearance in the winter and beauty in the summer. Narrow-leaved evergreens, spruces, firs, hemlocks, etc., are known as conifers. Many are too large for small estates, but we have for years been getting together a collection of dwarf evergreens that never assume Iarge proportions, but become more and more beautiful with age, never becoming ragged and unsightly. 
Fill out Order and Send to

\section{The Bay STATE Nurseries}

W. H. WYMAN \& SON, OWNERS

North Abington, Massachusetts

Ship on $b y$ We will ship the best way if left to us Parcel Post Express, Freight

Name

Street and Number

Town or City State

Express or Freight Station

Enclosed is (check or money-order) for

TERMS: Cash with order, F.O.B. North Abington, except to persons who satisfy us as to their responsibility

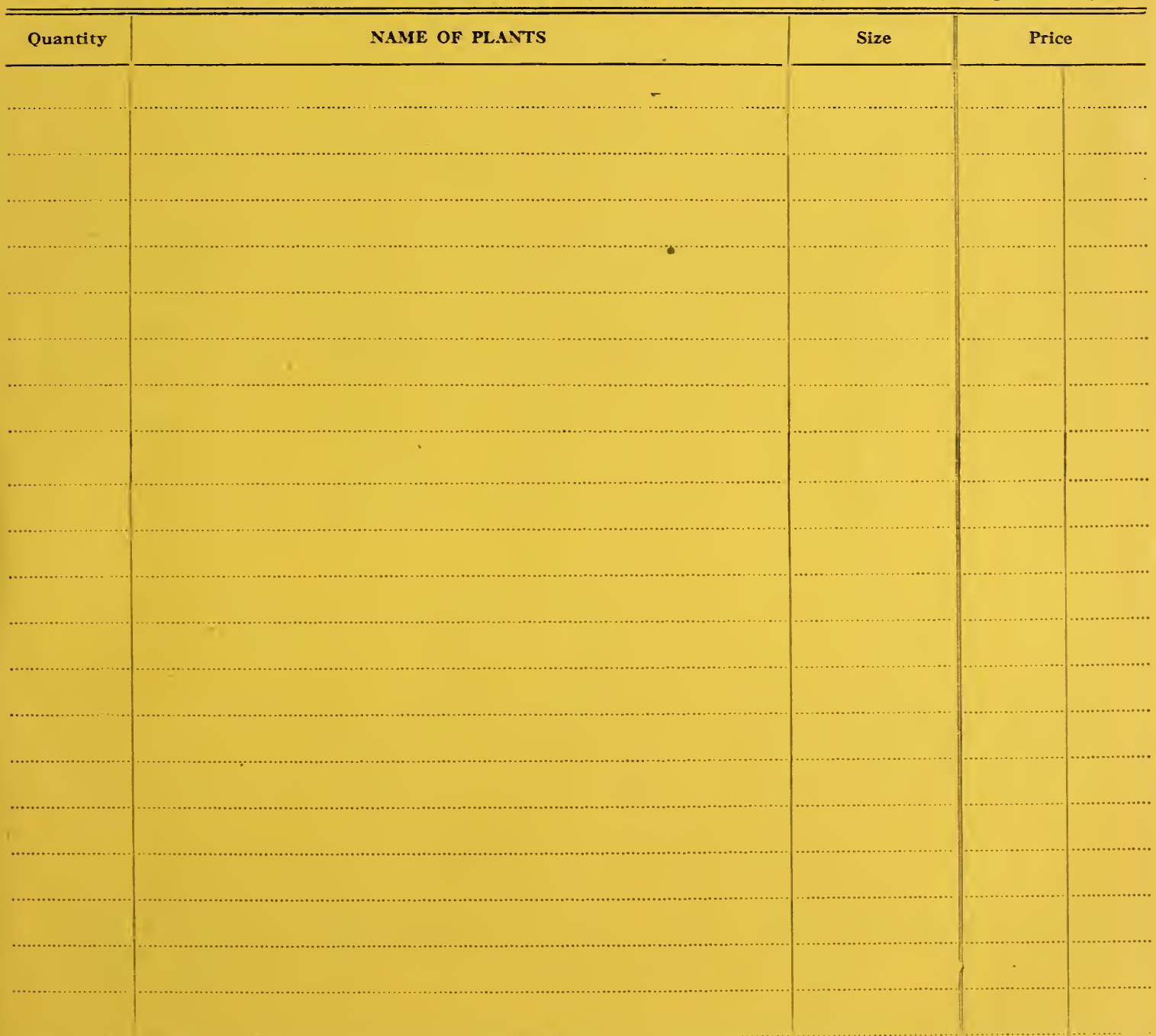





\section{General Directions to Customers}

-PLEASE READ CAREFULLY BEFORE ORDERING

Order Early. Do not delay until the last moment before sending in your order. The reason is apparent. It is to our mutual advantage that you order early.

How to Order. All orders should be written plainly (this will insure against mistakes), stating the method of transit, whether by express, freight, parcel post, or truck. Write plainly the post office, express, or freight stations, as the case may be, and sign your name plainly.

Packing and Shipping Directions. All trees and plants are labeled and carefully packed and delivered to the forwarders here at North Abington at prices published semi-annually and which will be furnished to all requesting them. If no instructions as to method of shipment are given, we shall use our best judgment. On account of the perishable nature of all nursery stock, we recommend that all small orders go by express. All evergreens are lifted with a ball of earth and are carefully burIapped, and can be so packed as to go safely by freight. But all herbaceous plants should be sent by express and never by freight except in carload lots. In all cases, the stock when it has been packed and delivered to the forwarder, is at the purchaser's risk, and should loss occur by delay in transit or accident by the forwarders, they and not we must be held responsible.

Terms. Our terms are cash, unless by special agreement. Charge accounts may be opened upon receipt of the names of two or more parties with whom the customer has credit relations, or by sending us bank or trade references, allowing us time for investigation. We can ship by express C. O. D. when desired, with charges for collection added to the bill-provided 20 per cent of the amount of the order accompanies the same as a guarantee. All accounts unpaid after the due date will be subject to sight draft without further notice.

Claims. Claims for reductions must be made immediately upon receipt of the goods. On account of weather and soil conditions and after-treatment it would not be possible for us to give any guarantee that the plants will grow. Neither should we be held responsible for errors or delinquencies of the forwarders.

Prices. Quality and not price only should be the guiding factor in purchasing nursery products. Cheap nursery stock is dear at any price. Our prices are not cheap; neither is our stock. Our prices are reasonable when quality and service are considered and are f. 0. b. Nurseries.

Shipping Season. Our spring shipping season begins about March 25 and continues until the last of May. In the fall we begin shipping with evergreens and perennials in August, deciduous trees and shrubs the last of September, and continue shipping until the ground freezes up for winter.

Non-Guarantee. We give no warranty, expressed or implied, as to quality, description, productiveness of any nursery stock that we sell. The only guarantee that we make is that our stock is alive at time of shipment and true to name. No complaints will be considered that are not made within ten days after receipt of order. Any stock ordered from this catalogue, found untrue to name, will be cheerfully replaced at the frrst favorable opportunity for planting, after it has been found not as ordered.

Location of Our Nurseries. The Bay State Nurseries are located in North Abington, Mass., 18 miles south of Boston, on the N. Y., N. H. \& H. R. R., half way from Boston to Plymouth. Trains leave the South Station at frequent intervals during the day. Visitors are always welcome. When notified, we meet visitors at the station with an automobile, and take them to the offrce.

Quick Transportation to Boston, New York, and the West. Our nurseries are so located that consignments arrive in Boston and New York the morning after the shipment is made. Shipments leaving here at noon for New York and points beyond arrive in New York the following morning. Shipments for Boston and points beyond, leaving here in the evening, arrive in Boston the following morning.

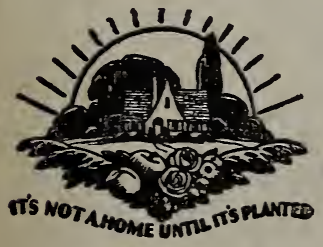

Inspector's Certificate Accompanies Every Shipment

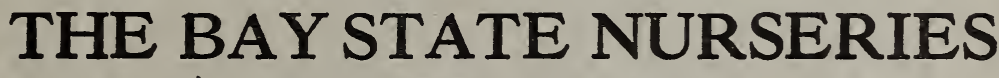
NORTH ABINGTON, MASS.

W. H. WYMAN \& SON, Proprietors 


\section{The Bay State Nurseries}

W. H. WYMAN \& SON

NORTH ABINGTON, MASS.

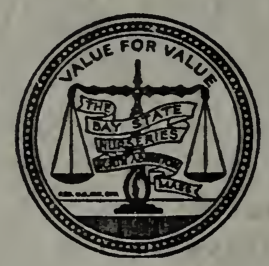

